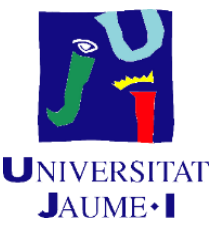

Doctoral Thesis

\title{
THE RELATIONSHIP BETWEEN \\ ECONOMIC FREEDOM AND ECONOMIC \\ GROWTH IN EU COUNTRIES
}

\author{
AUTHOR: \\ Ivana Brkić
}

DIRECTOR:

Javier Sánchez Garcia

Castellón de la Plana, June 2020 


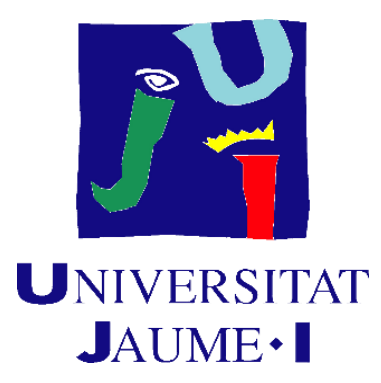

Programa de Doctorado en Economía y Empresa

Escuela de doctorado de la Universitat Jaume I

\section{LA RELACIÓN ENTRE LA LIBERTAD ECONÓMICA Y EL CRECIMIENTO ECONÓMICO EN LOS PAÍSES DE LA EU}

Memoria presentada por Ivana Brkić

para optar al grado de doctor de la Universitat Jaume

El doctorando
Nuana Brkic

Ivana Brkić

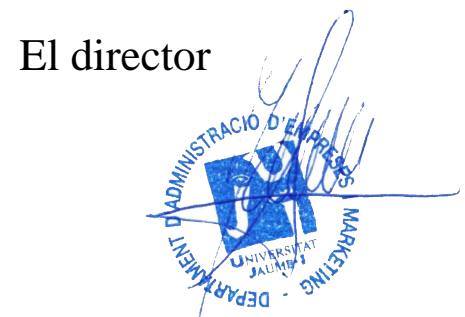

Javier Sánchez Garcia

Castellón de la Plana, Junio de 2020 


\section{Contents}

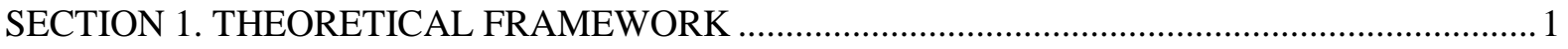

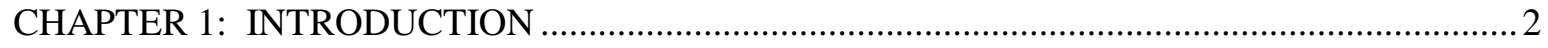

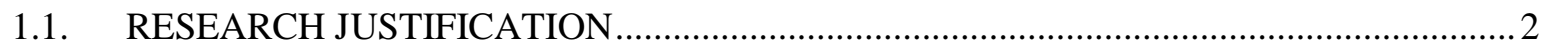

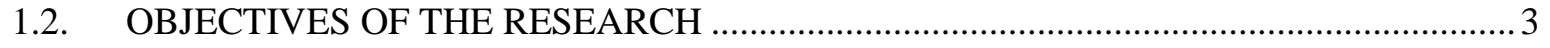

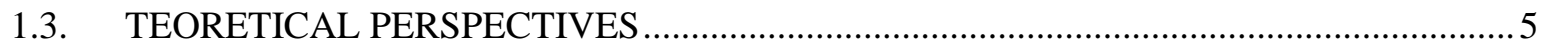

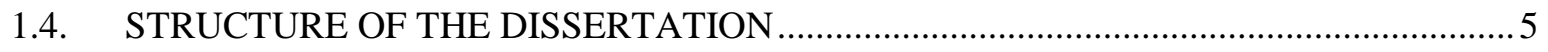

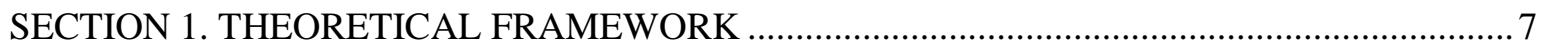

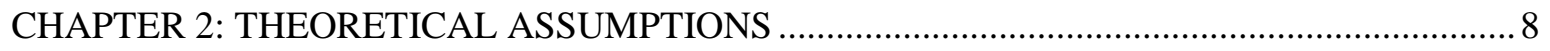

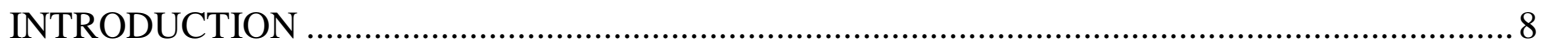

2.1. THEORETICAL ASSUMPTIONS ABOUT ECONOMIC FREEDOM ….............................. 10

2.1.1. THE DIRECTIONS OF DEVELOPMENT OF ECONOMIC THOUGHT FROM THE

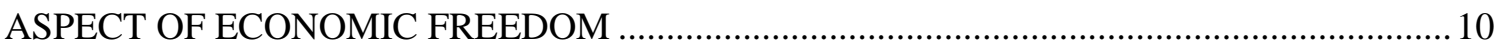

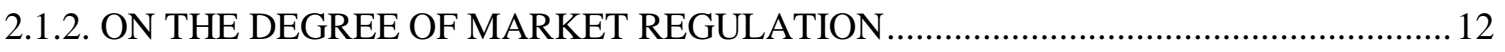

2.1.3. ECONOMIC INSTITUTIONS AS DETERMINANTS OF ECONOMIC GROWTH ...... 14

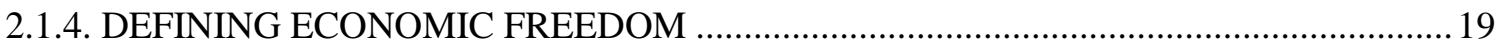

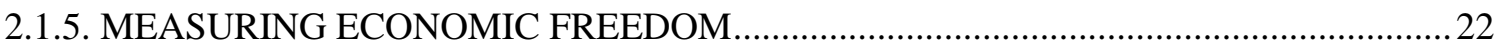

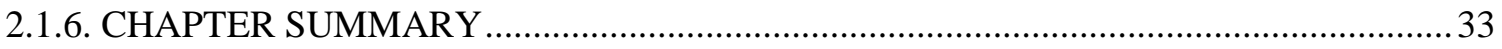

2.2. CONCEPT OF THE ECONOMIC FREEDOM INDEX OF THE HERITAGE FOUNDATION .34

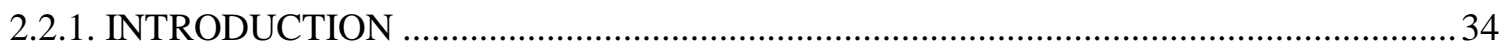

2.2.2. THEORETICAL INTERPRETATION OF THE ECONOMIC FREEDOM INDEX ......... 34

2.2.3. THEORETICAL INTERPRETATION OF THE ECONOMIC FREEDOM SUBINDICES .35

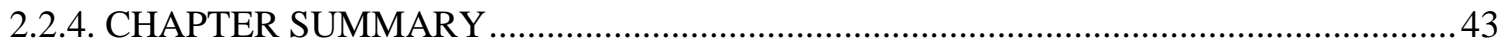

2.3. ECONOMIC FREEDOM AS A SUBJECT OF SCIENTIFIC RESEARCH ............................. 44

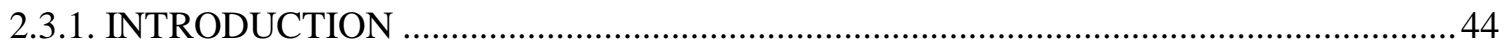

2.3.2. EXAMINING THE RELATIONSHIP BETWEEN ECONOMIC FREEDOM AND

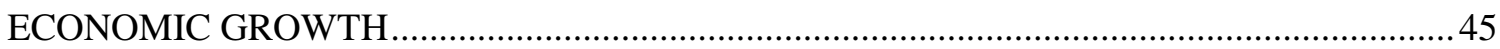

2.3.3. EXAMINING THE RELATIONSHIP BETWEEN DIFFERENT COMPONENTS OF

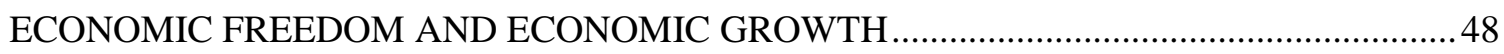

2.3.4. EXAMINING THE RELATIONSHIP BETWEEN LEVEL VS. CHANGE IN THE

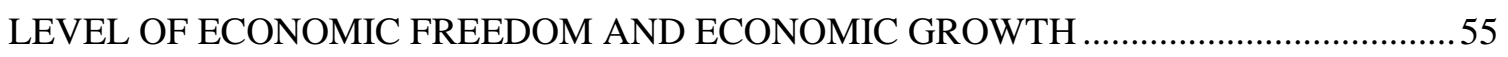

2.3.5. EXAMINING THE CAUSALITY IN THE RELATIONSHIP BETWEEN ECONOMIC

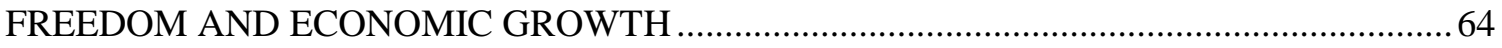

2.3.6. EXAMINING THE RELATIONSHIP BETWEEN POLITICAL FREEDOM, ECONOMIC FREEDOM AND ECONOMIC GROWTH .................................................... 72 
2.3.7. EXAMINING THE STATE AND IMPACT OF ECONOMIC FREEDOM WITHIN

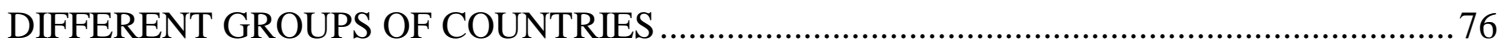

2.3.8. EXAMINING THE STATE AND CHANGES OF ECONOMIC FREEDOM OF

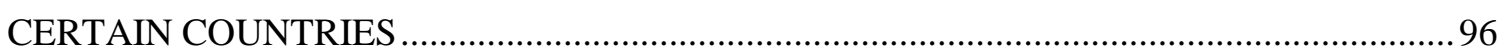

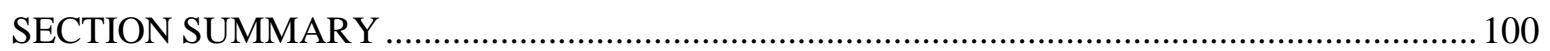

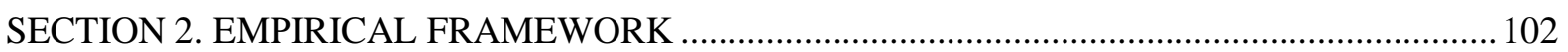

CHAPTER 3: THE EMPIRICAL RESEARCH METHODOLOGY …............................................ 103

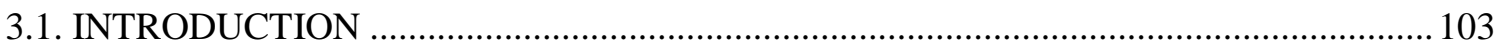

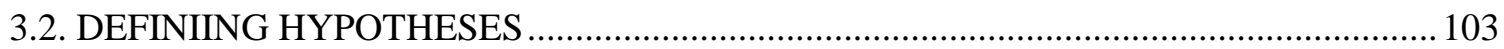

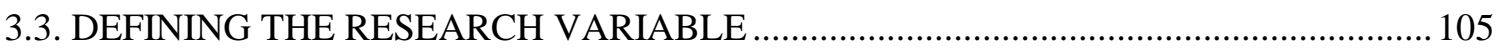

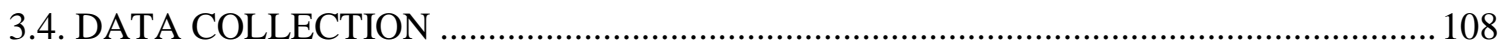

3.5. SELECTION METHOD, SIZE AND CONSTRUCTION OF THE SAMPLE .................... 108

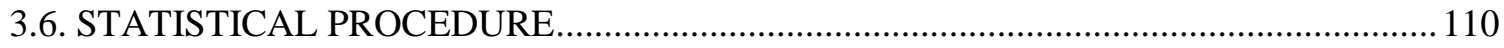

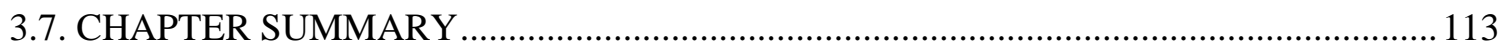

CHAPTER 4: RESULTS OF THE EMPIRICAL RESEARCH .................................................... 114

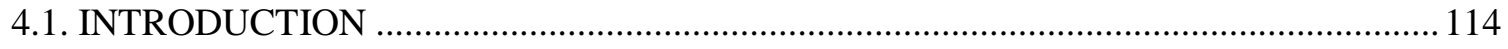

4.2. RESULTS OF THE PANEL ANALYSIS ON THE IMPACT OF ECONOMIC FREEDOM

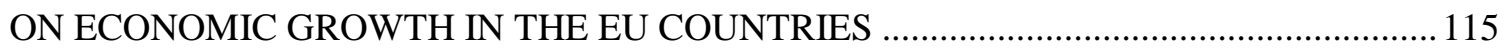

4.4. RESULTS OF THE PANEL ANALYSIS ON THE IMPACT OF ELEMENTS OF ECONOMIC FREEDOM ON ECONOMIC GROWTH IN THE EU COUNTRIES ................. 126

4.5. RESULTS OF THE PANEL ANALYSIS ON THE IMPACT OF CHANGE OF ECONOMIC FREEDOM ON ECONOMIC GROWTH IN THE EU COUNTRIES ................ 141

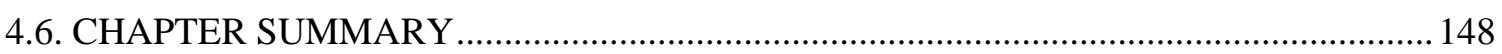

CHAPTER 5: DISCUSSION, CONCLUSIONS, LIMITATIONS AND FUTURE LINE OF

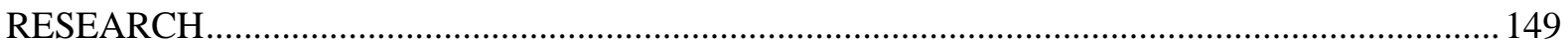

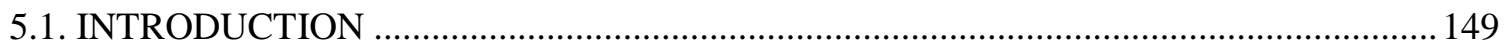

5.2. DISCUSSION OF THE RESULTS OF PANEL ANALYSIS ON THE IMPACT OF ECONOMIC FREEDOM ON ECONOMIC GROWTH IN THE EU COUNTRIES ................ 150

5.3. DISCUSSION OF THE RESULTS OF PANEL ANALYSIS ON THE IMPACT OF ELEMENTS OF ECONOMIC FREEDOM ON ECONOMIC GROWTH IN THE EU COUNTRIES 151

5.4. DISCUSSION OF THE RESULTS OF PANEL ANALYSIS ON THE IMPACT OF CHANGE OF ECONOMIC FREEDOM ON ECONOMIC GROWTH IN THE EU

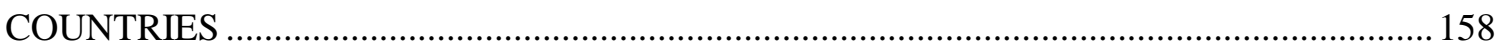

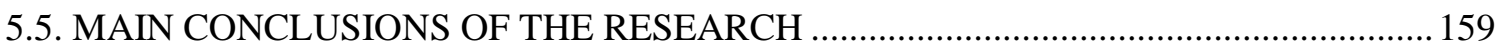

5.6. LIMITATIONS AND FUTURE LINE OF RESEARCH................................................ 162

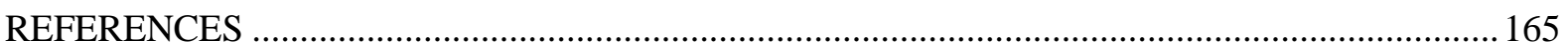




\section{List of tables}

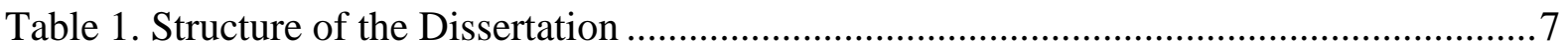

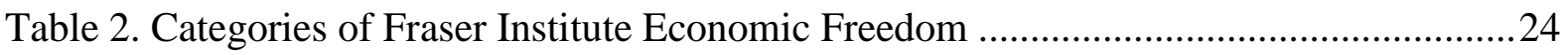

Table 3. Categories of the Heritage Foundation economic freedom .....................................26

Table 4. Categories of the Economic Freedom Index of the Heritage Foundation that have been in use since 2017

Table 5. Comparison of the Economic Freedom Index of the Fraser Institute and the Heritage Foundation

Table 6. Similarities and differences in the interpretation of categories of economic freedom

Table 7. Tabular overview of conducted research on the relationship between (change of) economic freedom and economic level and/or growth

Table 8. Overview of the interconnections between economic freedom, political freedom and economic growth in the studies presented

Table 9. Tabular overview of conducted research on the relationship between (change of) economic freedom and economic level and/or growth within different group of countries....89

Table 10. Tabular presentation of the results of the examinations so far of the situation and

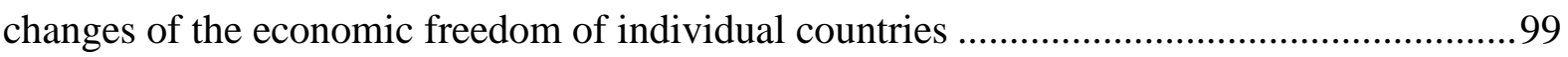

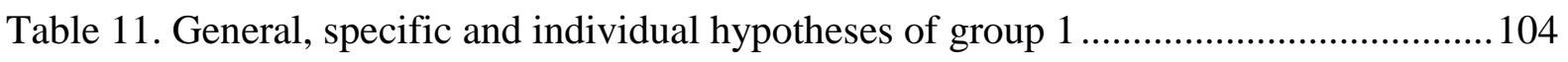

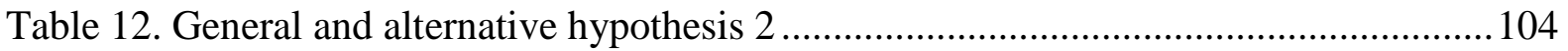

Table 13. Description and labels of dependent, independent and control variables .............. 106

Table 14. Descriptive statistics of dependent, independent, and control variables ............... 115

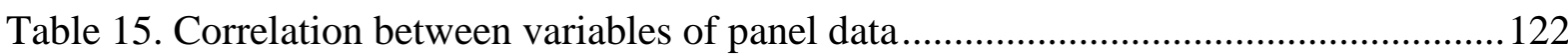

Table 16. Fixed effects model - the impact of economic freedom on economic growth in European Union countries.

Table 17. Random effects model - the impact of economic freedom on economic growth in European Union countries.

Table 18. Final fixed effects model - the impact of economic freedom on economic growth in

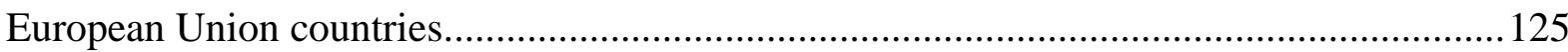

Table 19. Descriptive statistics of the dependent, independent and control variables .......... 126

Table 20. Correlation between variables of panel data ........................................................ 133

Table 21. Fixed effects model - the impact of subindices of economic freedom on economic growth in the European Union countries 134 
Table 22. Random effects model - the impact of subindices of economic freedom on economic growth in the European Union countries.

Table 23. Improved fixed effects model - the impact of subindices of economic freedom on economic growth in European Union countries

Table 24. Reduced fixed effects model - the impact of subindices of economic freedom on economic growth in European Union countries

Table 25. Reduced random effects model - the impact of subindices of economic freedom on economic growth in European Union countries

Table 26. Final fixed effects model - the impact of subindices of economic freedom on economic growth in European Union countries.

Table 27. Correlation between variables of panel data

Table 28. Fixed effects model - the impact of change of economic freedom on economic growth in the European Union countries

Table 29. Random effects model - the impact of change of economic freedom on economic growth in the European Union countries

Table 30. Final fixed effects model - impact of change of economic freedom on economic growth in European Union countries

Table 31. Comparison of findings of the research on the impact of elements of economic freedom with those of other authors 


\section{List of graphs}

Graph 1. Changes in Growth per country $(1994-2018)$................................................. 116

Graph 2. Heterogeneity in economic growth across years in selected sample .....................117

Graph 3. Heterogeneity in economic growth across countries in the selected sample ..........117

Graph 4. Relationship between independent and dependent variable in each country.......... 119

Graph 5. Correlation between Index of economic freedom and Economic growth for each

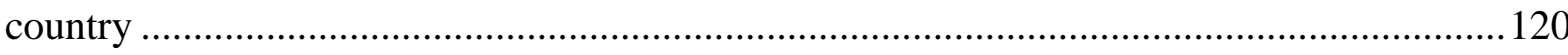

Graph 6. Correlation between control variable Gross capital formation (\% of GDP) and

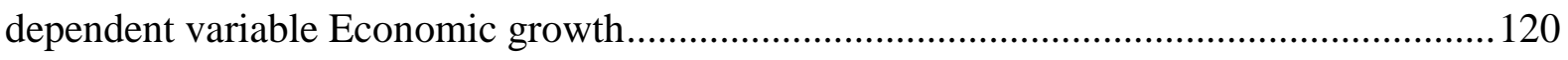

Graph 7. Correlation between Foreign direct investment, net inflows (\% of GDP) and GDP

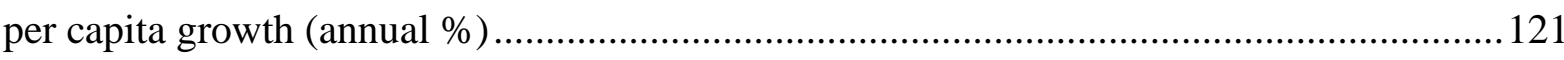

Graph 8. Correlation between Trade (\% of GDP) and GDP per capita growth (annual \%) .. 121 Graph 9. Plot of the dependent variable GDP per capita growth (annual \%) over time for the selected sample

Graph 10. Correlation between subindex Property rights and GDP per capita growth (annual $\%)$

Graph 11. Correlation between subindex Government integrity and GDP per capita growth (annual \%)

Graph 12. Correlation between subindex Tax burden and GDP per capita growth (annual \%)

Graph 13. Correlation between subindex Government spending and GDP per capita growth (annual \%) 128

Graph 14. Correlation between subindex Business freedom and GDP per capita growth (annual \%)

Graph 15. Correlation between subindex Labor freedom and GDP per capita growth (annual $\%)$

Graph 16. Correlation between subindex Monetary freedom and GDP per capita growth (annual \%)

Graph 17. Correlation between subindex Trade freedom and GDP per capita growth (annual $\%)$

Graph 18. Correlation between subindex Investment freedom and GDP per capita growth (annual \%) 
Graph 19. Correlation between subindex Financial freedom and GDP per capita growth

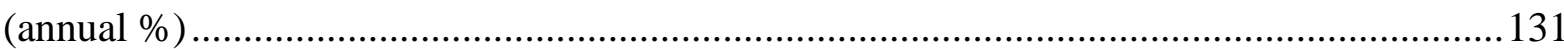

Graph 20. Relationship between independent and dependent variable in each country ........ 142 Graph 21. Correlation between Change of index of economic freedom and GDP per capita growth (annual \%)

\section{List of figures}

Figure 1. Correlation between variables of panel data

Figure 2. Correlation between variables of panel data

Figure 3. Correlation between variables of panel data 
SECTION 1. THEORETICAL FRAMEWORK 


\section{CHAPTER 1: INTRODUCTION}

\subsection{RESEARCH JUSTIFICATION}

Economic freedom is the right of every individual to work, to have their labor and property at their disposal and to control them. It implies minimal intervention by the state, which is reflected primarily in the protection of fundamental property rights, as well as the implementation and efficiency of the law in enforcing contracts. All other segments of economic flows need to be relieved of state interference and left to actions on the market. In order to substantiate with solid empirical evidence the theoretical view that economic liberalization is useful for achieving economic growth, it is necessary to quantify the given qualitative category and make it measurable and comparable. For more than two decades, the Heritage Foundation has been following the level of economic liberalism in almost every country in the world and based on it, in cooperation with the Wall Street Journal, it publishes a report on the state of economic freedom in the world every year based on the Index of Economic Freedom. The Economic Freedom Index is composed of ten elements grouped into four basic pillars of economic freedom: 1) Rule of Law, which consists of sub-indices Protection of Property Rights and Freedom from Corruption used to analyze judicial independence, the efficiency of law and contract enforcement, and the presence of corruption in all segments of society; 2) Limited Government, monitors the state of Fiscal Freedom through the extent of tax burden and Public Spending in the observed countries; 3) Regulatory Efficiency is a pillar of economic freedom dedicated to aspects of Business Freedom, Labor Freedom and Monetary Freedom, which measure the extent of bureaucratic restrictions in the process of business processes, the degree of regulations in the labor market and the stability of prices formed in the market; 4) Market Openness Pillar, expressed by Trade Freedom, Investment Freedom and Financial Freedom, is dedicated to examining the openness and presence of international trade in goods, services and money, as well as the presence of foreign and domestic investors and financial institutions, operating independently of state control. The given index and its categories will be applied in this thesis so as to determine the impact of economic freedom on economic growth within 28 EU Member States observed from 1995 to 2018. 
Previous research has found that aggregate index of economic freedom does not necessarily have to be a precise indicator of the economic growth of certain countries, and that it is often necessary to specify those aspects of economic freedom that determine the extent of economic activity achieved in the countries observed. Our aspirations were to determine whether equal, harmonized, balanced application of all aspects of economic freedom leads to economic expansion in the countries of the European Union, or it is about certain segments which are more determinative of the chosen area.

Although the criteria for entry and membership of the European Union are the same and binding for all Member States, there are nevertheless certain specificities and differences among the countries concerned. As the foundations of the European Union are based on the so-called four freedoms: freedom of movement of goods, freedom to provide services, freedom of movement of capital and freedom of movement of people (Medović, 2018), the aim of this research is to examine how much these (and other freedoms) contribute to economic growth in member states of the European Union.

As contemporary theories of economic growth have singled out economic freedom as a significant factor in the country's economic development and prosperity, the core contribution of this doctoral thesis is reflected in the examination of this claim on a sample of European Union (EU) countries. Further scientific contribution can be observed in identifying those elements of economic freedom that contribute most to economic growth in EU Member States, which will be achieved through empirical research. It will serve to provide evidence that support the theory of the relationship between economic freedom, its change, its components and economic growth, in a sample of EU Member States.

Given the great importance and impact of economic freedom on the prosperity of individuals and entire nations, it is considered relevant and necessary to deal with this topic in order to advance the global economic progress of society.

\subsection{OBJECTIVES OF THE RESEARCH}

The objective of this doctoral thesis is to examine the impact of economic freedom expressed through the Economic Freedom Index of the Heritage Foundation on the economic growth of European Union countries. The research will also examine the impact of the elements (sub-indices) of economic freedom on the percentage growth of gross domestic 
product per capita in order to determine which of the segments contributes most significantly to the expansion of the economies of the European Union.

The thesis will use the Heritage Foundation's Economic Freedom Index data to define and measure the impact of economic freedom on the overall production of goods and services, expressed as gross domestic product percentage growth per capita.

Since the Index of Economic Freedom is composed of ten categories or areas that equally define the state of economic freedom, it will be determined with great precision which of the given segments contributes most to the economic growth of the EU Member States. Protection of property rights, corruption, fiscal burden, public spending, ease of doing business, working conditions, international openness as regards trade, investment and financial flows and other aspects in the economic sphere of the selected countries, expressed through elements of the Heritage Foundation's Economic Freedom Index will be the subject of this research in the narrow sense in terms of determining their impact on economic growth.

In order to stimulate the economic growth of the European Union, the thesis raises key questions with the aspirations of answering some of the following questions through empirical and theoretical research:

Does economic freedom contribute to the economic growth of the European Union?

$>$ Is the European Union characterized and defined by economic freedom in general, or are only some of its aspects determinant of defining the economic growth of this area?

$>$ Can the promotion of the rule of law manifested in stronger protection of property rights and reduction of corruption encourage economic growth in the European Union?

$>$ Can government restrictions on fiscal levies and restrictions on public spending have a decisive influence on the economic growth of EU countries?

$>$ Does the low level of efficient regulation, hampered by slow bureaucracy in the business process, rigid laws and a high degree of protection of labor rights, as well as pronounced price controls, or high inflation rates, significantly diminish the chances of economic growth of EU countries?

$>$ Why can market openness, freedom of investment and the manifestation of international financial flows lead to the advancement of global economic growth in European Union countries?

The primary objective of the research is to determine the impact of economic freedom on the percentage growth of GDP per capita in a sample of EU Member States. 
The specific objective of the research is to examine the complexity of the relationship between the elements of economic freedom and the growth of GDP in a defined area of the European Union.

The scientific objective of the research is reflected in the contribution of scarce theoretical knowledge in the field of the impact of economic freedom on the most important economic indicator - economic growth. The stated objective is planned to be achieved through an empirical research process, by confirming or refuting the hypotheses set out in the thesis on the given impact in the relations between economic freedom, its components and economic growth in a sample of EU countries.

The social objective is to determine which aspect of economic freedom is particularly conducive (or detrimental) to economic growth from the perspective of the observed EU Member States, and using that knowledge to create and conduct macroeconomic policies in order to strengthen an integrated and economically strong geopolitical area.

The practical objective is closely linked to the social objective, since the focus of the research is a macroeconomic topic, and therefore these results may be valuable to macroeconomic policy makers for the purpose of defining the direction and determinants of European Union development.

\subsection{TEORETICAL PERSPECTIVES}

Although there is no single definition of economic freedom, there is a widely held view that economic freedom is the right of every person to have their labor and property at their disposal and to control them.

\subsection{STRUCTURE OF THE DISSERTATION}

The concept of the doctoral dissertation is determined by the methodology of writing a scientific paper, which consists of the following:

In the introductory part - Chapter 1, the justification of the research is elaborated, the subject of the research specified and the primary, specific, scientific, social and practical objective of the research determined; at the same time - the content that will be processed and presented within the dissertation is outlined. 
Ivana Brkić

Chapter 2 gives an overview of theoretical assumptions that narrowly define the field of research: the directions of development of economic thought from the point of view of economic freedom are historically and chronologically interpreted, it is debated about the optimal degree of market regulation, and on the basis of previous research the importance of economic institutions as determinants of economic growth and development is pointed out. Attention is further devoted to defining the concept of economic freedom, the procedures for its quantification by certain institutions, after which the focus is placed on the theoretical interpretation of the Economic Freedom Index and its components constructed by the Heritage Foundation, which publishes a report on the state of economic freedom in the world every year.

Below is an overview of the scientific findings to date on the topic covered. Numerous authors have examined the relationship between economic freedom, its elements and economic growth, the findings of which are presented first. Other authors have analyzed the change (as opposed to level) of economic freedom and such impact on the economic (welfare) state and progress, whose contributions are also made explicit. Studies that dealt with the causal relationship between economic freedom and growth are then presented. As the aim of the research was to examine relations within one economic and political communitythe European Union, the subject of further interest and presentation was also the insights of other authors who were exploring the same or another geo-economic area.

The third part is entirely devoted to the empirical research conducted for the need of the dissertation. After presenting the methods and means of data collection and processing, a brief review of econometric methods that will be applied within the empirical part of the research, and defining the variables, the concrete process of quantitative research is begun.

In the fourth part, with the help of descriptive statistics, basic characteristics of all variables are presented, on the basis of which further selection of research methods could be made. A correlation analysis was also performed to establish the basic relationships between the dependent, independent, and control variables. Panel analysis, as the central analysis for determining the impact of (change of) economic freedom and its elements on economic growth in the sample of European Union countries, was performed below and the results obtained are presented in tables and graphs.

The fifth part is devoted to the discussion of the given results, commented on and compared with the results of other authors on this or a related topic. Based on this analysis, certain hypotheses were accepted or rejected. In the end, concluding remarks on the subject 
of research within this doctoral dissertation are presented so as recommendations for further research.

Table 1. Structure of the Dissertation

\begin{tabular}{|c|c|c|}
\hline \multirow{4}{*}{$\begin{array}{c}\text { SECTION } 1 . \\
\text { THEORETICAL } \\
\text { FRAMEWORK }\end{array}$} & Chapter 1 & $\begin{array}{l}\text { Introduction and } \\
\text { research justification }\end{array}$ \\
\hline & \multirow{3}{*}{ Chapter 2} & $\begin{array}{l}\text { Theoretical assumptions } \\
\text { about economic freedom }\end{array}$ \\
\hline & & $\begin{array}{l}\text { Concept of the economic } \\
\text { freedom index of the } \\
\text { Heritage Foundation }\end{array}$ \\
\hline & & $\begin{array}{ll}\text { Economic } & \text { freedom as a } \\
\text { subject } & \text { of scientific } \\
\text { research } & \end{array}$ \\
\hline \multirow{3}{*}{$\begin{array}{l}\text { SECTION } 2 . \\
\text { EMPIRICAL } \\
\text { FRAMEWORK }\end{array}$} & Chapter 3 & $\begin{array}{l}\text { The empirical research } \\
\text { methodology }\end{array}$ \\
\hline & Chapter 4 & $\begin{array}{l}\text { Results of empirical } \\
\text { research }\end{array}$ \\
\hline & Chapter 5 & $\begin{array}{l}\text { Discussions, } \\
\text { conclusions, limitations } \\
\text { and future line of the } \\
\text { research }\end{array}$ \\
\hline
\end{tabular}

Source: Author. 
Ivana Brkić

\section{CHAPTER 2: THEORETICAL ASSUMPTIONS}

\section{INTRODUCTION}

Within the theoretical framework in the dissertation, the basic terms that are the subject of the research (and) in its empirical part are defined. The focus of the qualitative analysis was the very concept of economic freedom, an overview of its history and chronology of presence in economic theory and practice, as well as ways of quantifying it using various indices that measure economic freedom in countries around the world. As the empirical part of the research analyzes the relationship between economic freedom and economic growth with the help of the Heritage Foundation's Index of Economic Freedom, the methodology of constructing the index itself is given a special significance in the theoretical part as well as a more extensive interpretation of each of its segments.

Economic freedom has been the subject of numerous scientific studies, and within the theoretical framework, the most relevant scientific results obtained in the previous period have been highlighted. Relations that have been established between economic freedom and economic growth have been discussed, as well as relationships between individual segments (sub-indices) of economic freedom and economic growth, given that numerous studies have found different contributions of individual elements of economic freedom to economic prosperity. The results of the research that dealt with causality (in Granger's sense) in the relations between economic freedom (or some of its parts) and economic growth are included and presented. Since a considerable number of authors have analyzed the relations between economic freedom and economic growth within a particular socio-economic-geographical group of countries, a detailed review of such studies and the results obtained is made so that a later comparison with the results of the empirical research within the dissertation could be made, given that the selected sample of countries also belongs to one such formation - the economic and political community - the European Union.

For the purpose of qualitative analysis of the identified research problem, adequate groups of methods, predetermined by such scientific approaches, were applied: 
Ivana Brkić

Generic analysis and historical method were applied in the analysis of the concept of economic freedom and its understanding in economic theory. The same methods were applied for the analysis of the methodology of the economic freedom index itself, as well as for the presentation of its application as a factor of economic development.

$>$ Methods of analysis and synthesis were used to anatomize and consolidate views and conclusions on the impact of economic freedom on the economies of different (groups of) countries, in order to identify, discover and study facts, laws and truths on a given topic.

> Content analysis was applied in a qualitative analysis of available and contemporary, mostly foreign, scientific and professional literature on the importance and impact of economic freedom on key indicators of economic growth and development.

$>$ Methods of induction and deduction, abstraction and concretization, as well as methods of generalization and specialization were used in the process of preparation of the entire dissertation, although their greatest contribution is seen in drawing conclusions about the impact of economic freedom on the economies of countries by interpreting the results obtained on the basis of the selected sample, as well as conducted secondary research.

Descriptive and explicit analysis is used to interpret the results of the research on the relationship between the Index of Economic Freedom and its subcategories with traditional economic indicators, and in particular the percentage growth of GDP per capita.

Structural analysis and classification method is used in defining, explaining and interpreting the subcategories of the Economic Freedom Index, while reproductive synthesis explains how the index elements are grouped into a comprehensive Economic Freedom Index of the Heritage Foundation.

$>$ The method of comparison was applied in comparing the Economic Freedom Index of the Heritage Foundation with other indices, which also aim to monitor a certain degree of economic (and/or other type of social) freedom in order to draw conclusions about the similarities and differences of the indices. The method of comparison was also used to compare the impact of economic freedoms on different economic and other indicators in different countries and regions. Comparison of the obtained results on the basis of empirical analysis with the results of other authors with the help of this method was done 
to discover similarities and differences on the impact of economic freedom on growth in different geo-economic areas.

$>$ The method of proving and refuting was applied in determining the truthfulness of the thesis and assumptions set out in the dissertation.

The given methods are intended to form the basis of reliable quantitative research in order to empirically answer the questions and issues raised within the research subject.

\subsection{THEORETICAL ASSUMPTIONS ABOUT ECONOMIC FREEDOM}

\subsubsection{THE DIRECTIONS OF DEVELOPMENT OF ECONOMIC THOUGHT FROM THE ASPECT OF ECONOMIC FREEDOM}

In his capital work "The Wealth of Nations", philosopher and founder of modern economics, Adam Smith raised the simple but essential question: "Why do some countries prosper and others do not?" (Smith, 2010). According to Borović (2014 a), Smith (2010) found that economic growth depends on two types of factors: production (especially technological development and human capital) and institutional (creating an environment that will stimulate growth). He believed in a system of spontaneous order, guided by natural human selfishness, without the need for intervention and control by political authorities. Nevertheless, he expressed the need for state interaction in securing contracts, private property and joint defense (Borović, 2014 a). As the father of economic liberalism, a theory that supports capitalism, Smith (2010) advocated the freedom of the individual to make economic decisions independently in a fully competitive, free market. Emerged from the need to protect against abuse of political power, this economic system has survived and governs the economy of the 21st century. Yet there have been periods in history that have shaken liberal ideology and demanded, instead of the invisible, the hand of salvation from the state. Until the Great Economic Crisis of 1929, the theoretical views of neoclassical theory were in line with the real social movements of the time (Marjanović, 2010). By working for their own interest, in an environment of free competition, individuals received a fair reward for personal effort and at the same time contributed to the general interest. There was a widespread view that society is a collection of individuals who seek to pursue their 
Ivana Brkić

private interests (without set social goals), while the government is formed to protect the individual rights established by the constitution (Clark, 1998). The state had legislative and executive power, and its primary task was to prevent any type and form of distortion of free competition. Then, in 1929, the world's largest financial crisis hit, which slowed economic growth, lowered the standard of living, formed armies of the unemployed, and grew into an economic and social crisis, causing the collapse of the capitalist system. Based on the ideas of John Maynard Keynes, for the sake of economic recovery, Theodore Roosevelt, the president of the United States of America (USA), turned to state interventionism in the economy. The state became the saviour of the economy and the guarantor of social security, which gave birth to the welfare state. Its main features were protection and equality (instead of freedom).

After the Second World War, there was a reconstruction of the Western economic system with the goals set at the International Conference in Bretton Woods. The objectives are the implementation of the international monetary system for the purpose of maintaining economic stability, strengthening global economic growth and promoting trade between countries. In order to achieve the objectives, institutions the International Monetary Fund and the International Bank for Reconstruction and Development were created.

Until the next crisis of the 1970s, the Keynesian interventionist approach was the dominant economic doctrine. With the advent of a new economic phenomenon - stagflation (inflation accompanied by recession), a new economic paradigm emerged - monetarism, a return to the market and neoliberalism. Formerly an alternative understanding of monetary theory by Friedrich Hayek now experienced a renaissance. Hayek's book "The Road to Serfdom" is the backbone of neoliberalism, according to which economic intervention by the state means the oppression of freedom, while freedom itself is the main driver of development (Hayek, 1943). The explicit opponents of state interventionism, especially in the field of monetary policy monetarists, advocated complete liberalization, free movement of goods, people and money in international flows, reduction of taxes for the wealthy and tax relief for the poor, as well as privatization of the public sector (Marjanović, 2010). All of the above, along with fiscal discipline, freedom to form interest rates and the exchange rate, general market deregulation, protection of private property, liberalization of foreign direct investment constitute the attributes 
Ivana Brkić

of the Washington Consensus on Economic Policy in force in most countries of the world. The global economy has led to globalization, the most important phenomenon of neoliberal theory, which integrates economies around the world, through trade, communications, financial flows, movement of people (work) and knowledge transfer (technology).

\subsubsection{ON THE DEGREE OF MARKET REGULATION}

"A society that puts equality before freedom will get neither; A society that puts freedom before equality will get a high degree of both."

Milton and Rose Friedman, Freedom to choose, 1980

Economic theory discusses the issue of state involvement in economic and other flows of socio-economic life of citizens. Liberals believe that eradicating socialism from life and practice in all countries of the world, cutting bureaucracy, abolishing subsidies and opening borders will lead to faster and more sustainable development. Another current argues that state interaction, intelligently applied, may produce better results (De Haan \& Sturm, 2000). Stiglitz (2009) points out numerous examples that balanced government involvement in economic flows results in economic growth and poverty reduction (East Asian, Scandinavian countries, and even the initial success of the United States may be attributed to government involvement in economic flows). Despite the opposing views, the idea of a free market is widely present and supported.

De Haan \& Sturm (2000) point out that the debate on the degree of market regulation is burdened by two things: the lack of a precise definition of the meaning and manner of measuring economic freedom, and the lack of data over a long period of time for a large number of countries. All this makes it difficult to analyze the link between economic freedom and prosperity.

As Samuelson \& Nordhaus (2009) conclude, by weighing the importance of relative achievement between the state and the market, scientific and other public often simplify the complex choices faced by a society. The market can be very stimulating, but without the right legal structure that encourages private initiative, investment and mutual trade, markets can be the 
Ivana Brkić

ones that distort capitalism embodied in growing inequality and poverty. The role of the state in the modern economy is to ensure market efficiency, reduce inequalities and foster economic growth and stability.

The progress of real production marked the twentieth century. Countries with the highest economic growth, such as Great Britain in the 19th and the USA in the 20th century, were role models to many countries striving for greater prosperity. The fall of the Berlin Wall in 1989 triggered the process of transition from socialism to capitalism. This implied a change in the economic system, and before the eyes of many contemporaries, an experiment was conducted in the world laboratory on the advantages or disadvantages of one compared to the other. Former socialist countries needed to prove that economic liberalization leads to economic growth. Poor economic performance is closely linked to institutional deficiencies, while good government-led economic policy is crucial to the economic development process (Frye \& Shleifer, 1996). The goal of transformation was to establish democracy and introduce market economy. This meant the need to end the monopoly power of the Communist Party and move towards political pluralism. In the domain of economics, this change entailed a reorientation from centrally planned economy to market economy, which implies the extension of economic freedom (Piątek, Szarzec \& Pilc, 2013).

As Ayal \& Karras (1998) explain, there are many examples which show that countries which reduced government direct involvement in economic activity demonstrate positive growth rates. Economic progress is linked to privatization policy, changes in laws that liberalize internal and external trade, and other measures that allow citizens to enjoy the fruits of their labor. The degree of implementation of such a policy varies from country to country, mainly due to the influence of the inherited and adopted social, cultural and institutional forms. There is still no consensus in scientific circles about whether there is a link between the political (economic) system and economic growth, or about the direction of causality if such a link is established.

In an economically free system, individuals are the basic economic actors, and the state assumes responsibility only for controlling the smooth functioning of the market. This creates the environment and builds the foundation for economic growth and development. Complete 
Ivana Brkić

freedom and a real opportunity to enter and exit the market create competition that encourages companies to thrive. Companies are making greater efforts to satisfy the demand and desires of the consumer for fear of being taken over by rival, which indirectly affects the well-being and prosperity of the entire society (Erdal \& Yenipazarli, 2013).

Individuals in a free society are believed to benefit from the growth of freedom, while its decline distorts the social and economic order (Sen, 1999). In this context, North (1990) analyzes the link between institutions and economic performance. He finds that the absence of institutions and rules results in a lack of trust in the enforcement of contracts, the protection of private property, the rule of law and the independence of the judiciary. Institutions that promote economic freedom are those that increase productivity (Dawson, 1998) and investment opportunities (Besley, 1995). North (1990) argues that high tax rates limit reaping the benefits of one's labor. High inflation also diminishes the intrinsic value of money, changes the terms of long-term contracts, and makes it difficult for individuals and companies to rationally plan the future. Restricting trade freedom and controlling capital flows neutralize exchange profits, reducing the yields of economic activities and productivity, which impedes investment incentives. Certainly, large government spending, as well as large-scale state-led production, can have the effect of reducing opportunities for individual production activities.

\subsubsection{ECONOMIC INSTITUTIONS AS DETERMINANTS OF ECONOMIC GROWTH}

Economic growth means increasing total production of goods and services in the long run. In other words, economic growth is an expansion of potential gross domestic product (Samuelson \& Nordhaus, 2009).

Economic growth is the most powerful mechanism for maintaining a high standard of living, which also implies a long-term increase in per capita income. In addition to achieving the specific economic and social goals of society, economic growth is one of the most important issues and aspirations of governments of all countries. 
Ivana Brkić

Although each country has its own specificities that can affect economic growth, regardless of the wealth of a country, there are four main wheels of economic growth (Samuelson \& Nordhaus, 2009):

1. Human resources (labor supply, education, discipline, motivation)

2. Natural resources (land, minerals, fuels, environmental quality)

3. Capital formation (machinery, factories, roads)

4. Technology (science, entrepreneurship, management).

Their relations are represented by the aggregate function of production:

$\mathrm{Q}=\mathrm{AF}(\mathrm{K}, \mathrm{L}, \mathrm{R})$

where $\mathrm{Q}=$ output, $\mathrm{K}$ = productive services of capital, $\mathrm{L}=$ labor inputs, $\mathrm{R}=$ natural resourceinputs, $\mathrm{A}=$ level of technology, $\mathrm{F}=$ production function.

However, there is no unique combination by which these four factors lead to prosperity. The United States, Europe, Asian countries have taken different paths to economic success. According to $\mathrm{Wu}$ (2011), more recent theorists believe that greater economic growth requires several of these factors. He points out that the problem of underdeveloped countries is not the lack of potential, but the inability to exploit them.

In order to understand why a certain country records a more dynamic rate of economic growth compared to others, the determinants of growth need to be established. Despite the numerous theories of economic growth distinguished by economic science, the specification of all variables that have an impact on economic growth has not yet been made. The dissertation raises the question of whether economic freedom is one of them. Owning physical resources is not in itself a guarantee of economic well-being. More often, they require the implementation of appropriate policies and the creation of institutions that will serve growth.

Gwartney, Holcombe \& Lawson (2006) provide a brief chronology of the development of theories of economic growth and its factors. According to them, neoclassical theory, based on the theory of growth constructed by Solow (1956) and developed by other authors (primarily Lucas, 1988; Romer, 1986, 1990), focused on the key aspects of growth, on physical and human resources, as inputs in the production process, as well as on technological advantages as 
Ivana Brkić

determinants of economic progress. In the theory of growth formulated by Solow (1956), the influence of government or institutions has not played a significant role (Carlsson \& Lundström, 2002).

Another wave of theories is based on the geographical/location aspect of growth. Thus, Sachs (2001), Gallup, Sachs \& Mellinger (1999) and Diamond (1997) argue that temperature climate and market accessibility are essential for achieving high levels of income and economic growth. Tropical areas, on the other hand, aggravate conditions and reduce worker productivity.

An institutional approach to growth theory, whose main supporters are Scully (1988, 2014), North (1990), Barro (1996), Landes (1998), Knack (1996, 2003), Hall \& Jones (1999) and Acemoglu, Johnson \&Robinson (2001) emphasizes the importance of creating an institutional environment conducive to market development. These are, first and foremost, protection of property rights, obligations to fulfill contractual obligations, freedom of exchange and marketbased pricing.

According to representatives of neoclassical growth theory, successful economies are those with a high capacity to accumulate human and physical capital, as well as those with advanced technology. However, the political and social environment, which also includes economic freedom, affects a country's ability to perform such accumulation. Thus, Solow (1956), Cass (1965) and Koopmans (1965) explained that differences in income are due to different savings rates and preferences while institutions were not mentioned in the context of the determining variables of economic growth. Subsequent followers Romer (1986) and Lucas (1988) discussed external factors that may affect growth but remained in the spirit of neoclassical theory. Only North \& Thomas (1973) interpreted the comparative growth through differences in institutions. According to them, institutions are rules of the game in a society or designed constraints that govern human interactions. According to Acemoglu, Johnson \& Robinson (2005), the most significant form of economic institutions are the protection of property rights and the existence of a (perfect) market, which shape social incentives, affect investment, physical and human capital, technology and the organization of production. Without protection of property rights, individuals will not be motivated to invest in physical and human capital, as well 
Ivana Brkić

as in the development of technology, while the absence of a free market will lead to misallocation of resources and profit from trade. Therefore, it is argued that institutions are endogenous variables of economic growth, and there is no doubt that their presence affects the greater wealth of a society (relative to others).

Until recently, there have been hardly any empirical works on examining the determination of economic growth by economic freedom. As Ayal \& Karra (1998) state, this is somewhat surprising, given that the idea of freeing economic flows from government intervention as a recommendation for economic growth dates back to the founders of modern economics (Smith, 2010), and many other great scholars (Locke, 1690 (1942); Malthus, 1820 (1986); Lewis, 1955 (2013); Mill, 1956; Friedman, 1962; North, 1988) spoke of the importance of institutions for economic growth. True, this can be explained by the lack of data to study the above-mentioned relations, but also by the fact that macroeconomics and the phenomenon of economic growth has mentally stood out in the recent past. Even as Smith (2010) defined, economic growth is determined by two groups of factors: production (especially technological development and human capital), which is in the spirit of neoclassical theory of growth and institutional factor (Borović, 2014 a). Adequate institutional framework implies a stimulating environment, a favourable investment climate and a functional legal system that protects property rights, all of which form the basis of economic prosperity. On the other hand, corruption and poor protection of property rights decrease the incentive to invest (Mauro, 1995). Moreover, technological innovations and their application through investment can be hampered by rigorous bureaucratic procedures, which themselves represent a suitable ground for corruption. Contributions to the theory of economic growth by scholars Romer (1986) and Lucas (1988) have made it possible to overcome the neoclassical models that put technology at the heart of explaining growth. Even North (1990) focused on economic institutions that regulate economic relations and thus can (de)stimulate economic agents to productivity. Subsequently, studies that attempted to measure the impact of institutions on economic growth began to be published (e.g. Barro 1991; Sachs \& Warner 1997). Many studies questioned whether institutions lead to prosperity directly by increasing factor productivity or indirectly through investment. Dawson (1998) proved that in both cases the institutional factor influences economic growth. The first empirical studies on the impact of economic institutions on economic growth were published by 
Ivana Brkić

Knack \& Keefer (1995), followed by Hall \& Jones (1999) and Acemoglu, Johnson \& Robinson (2001, 2002), using the only available and insufficiently accurate indicators on the presence of institutions covering property rights protection and protection against risk expropriation, in the period between 1985 and 1995. By looking at the bivariate relationship, scientists found that countries with stronger property rights, that is, better economic institutions, have higher average incomes. Other types of institutions, such as political and civil liberties have also been examined eg. Kormendi \& Meguire (1985), Barro (1991, 1996), but their results were diverse. Hall \& Jones (1997) defined economic infrastructure as a collection of laws, institutions, and government policies that make up the economic environment. The institutional infrastructure in a coalition with standard constraints on economic theory determines production performances and economic opportunities. An efficient government that provides a strong justice system and implements a policy of protecting property rights is the embodiment of a well-defined economic structure. Economic institutions create economic performances and (perhaps more importantly) influence the distribution of resources. They are determined by the collective choice of society that determines their economic consequences. The possibility of choice can turn into a problem, since a different set of economic institutions makes different distribution of resources and thus satisfy different interest groups. The political power of some may thus take precedence over a more effective choice.

The starting point is that the difference in institutions leads to different degrees of economic growth, based on the idea that people organize their societies in a way that either leads to progress or to stagnation and decline. One way of organizing will direct and encourage people to innovate, take risks, have an equal chance of success and thus achieve economic growth together. The other one, constrained by system, bureaucracy, control and corruption, will slow down the economy and create poverty. 
Ivana Brkić

\subsubsection{DEFINING ECONOMIC FREEDOM}

There is no universally accepted definition of the concept of economic freedom, although most recognized scholars agree that economic freedom is the fundamental right of every person to have their work and property at their disposal and to control them.

As defined by Gwartney \& Lawson (1997), representing the Fraser Institute, the economic freedom of an individual is reflected in the ability to acquire property without the use of force, fraud or theft, and to have it protected from physical invasion by others; they are free to use, exchange or donate the acquired property, as long as their actions do not jeopardize the identical rights of others.

O'Driscoll, Feulner \& O'Grady (2003), representing the Heritage Foundation, define the economic freedom as a condition in which individuals are free to work, produce, spend, invest as they wish. Their security and protection are thus enabled by the state, which at the same time undertakes not to violate the said rights of economic agents. In an economically free society, the role of the state comes down to the protection of property and enforcement of contracts (Gwartney, Holcombe \& Lawson, 2004). An economically free state allows for an unhindered flow of labor, capital and goods, and refrains from coercion and restraints except in the case of defense and protection of freedom as such $(\mathrm{Wu}, 2011)$. The absence of governmental corrections or constructions in the area of production, distribution and consumption of goods and services, except in the case of applying the necessary measures to protect and maintain freedom as a concept, characterizes economic freedom (O'Driscoll et al., 2003). If a state fails to protect private property, engages in confiscation of property without full compensation and restricts voluntary exchange, it is the one that disrupts the economic freedom of its citizens. In practice, the government constructs negative incentives by such actions, in terms of entrepreneurship and productivity, creating skepticism in people about making profits based on their productive efforts (Panahi, Assadzadeh \& Refaei, 2014).

Miller \& Kim (2016) interpret the restriction of economic freedom through excessive government intervention in the field of economic activities, which thus obstruct the autonomy of 
Ivana Brkić

individuals in pursuit of a better standard of living. The dualism of economic freedom goals is reflected in the following: minimize government coercion or constraints, and create and maintain a shared sense of freedom for all citizens (Miller \& Kim, 2016). Governmental actions are often necessary to form the unity of the people. As the power of authorities is difficult to contain, it can easily cross the line of the necessary. Often, in the name of equality or to meet some seemingly noble social needs, restrictions are imposed that put the few in a privileged position (Miller \& Kim, 2016).

Excessive government presence in economic flows increases the costs of the entire society. As understood by De Haan, Lundström\& Sturm (2006) economic freedom is a major component of a market economy. At its core are protection of private property, freedom of choice and voluntary exchange (De Haan et al., 2006). Substituting market mechanisms with government decisions, entrepreneurial energy is distorted into so-called 'rent seeking', which inevitably decreases the wealth of a nation (Miller \& Kim, 2016).

In its range, economic freedom means freedom and right at all stages of social reproduction: production, exchange, distribution and consumption. Decentralized decisionmaking, as a characteristic of the spirit of an economically free society, implies that individuals are free to work, produce, consume and invest the way they want. In the report of the Heritage Foundation, Miller \& Kim (2013) elaborate on and thoroughly define economic freedom. They explain that in an economically free society, every person controls the fruits of their labor, individuals succeed or fail on the basis of their effort and ability, while the government promotes equal conditions in terms of engaging resources for production and consumption. It goes without saying that some government action is necessary for the peaceful development of a society. That way, the population pays taxes that would ensure public safety, property protection, common defense, maintaining the stability of money, etc. There are also "public goods" that the government provides more efficiently than the private sector could.

Economic freedom does not mean anarchy as stated by Miller, Holmes \& Feulner (2013). Individuals who enjoy the benefits of economic freedom have a responsibility to respect the 
Ivana Brkić

economic rights and freedom of others within the rule of law, while the state is established to provide the basics of protecting positive economic rights such as property and contracts.

Gwartney, Lawson \& Block (1996) distinguish between economic, political, and civil liberties. Political liberty is reflected in the fairness of elections and the existence of a political alternative, as well as the freedom of citizens to participate in political elections, lobby and select candidates. Civil liberty encompasses freedom of the press, as well as the right of individuals to gather and express different religious beliefs and express views without fear of physical or any other violence. Therefore, Gwartney et al. (1996) emphasize that a country can be very liberal in political terms, and that at the head of the country is a democratically elected party which protects civil liberties but still adopts policies that are contrary to economic freedom.

While Gwartney et al. (1996) distinguish between political, economic, and civil liberties, De Haan \& Sturm (2000) distinguish between individual and collective freedom. Individual freedom means the right to undertake and conduct economic activities that are protected from arbitrary control and interference by state and other authorities and individuals. Collective freedom is an indicator of the extent to which the economic system is free and the result of the expressed will of the majority of citizens as opposed to the domination of the will of the ruling few.

Kešeljević (2013) views economic (and divides) freedom as a subjective and objective category. The levels of economic freedom (at different historical and political economic moments) can be interpreted separately. Thus, equal level of economic freedom may be perceived differently by individuals (subjective aspect). The objectivity of economic freedom is created when a certain level of economic freedom is a reflection of the general consensus in a society.

Berlin (1992) clarifies the concepts of negative versus positive freedom. Negative freedom is characterized by the absence of any constraints whereas positive freedom implements restrictions in order to achieve the common good. In the context of economic freedom, negative 
Ivana Brkić

freedom implies the smooth operation of individuals (within the legal framework), while positive freedom implies a controlling and active role by the government over individuals.

\subsubsection{MEASURING ECONOMIC FREEDOM}

In order to define the impact of economic freedom on economic growth, economic freedom needs to be a measurable category. The complexity of "calculating" the level of economic freedom lies in its qualitative rather than quantitative feature. Consequently, a certain extent of subjectivity and imprecision is an inevitable element of any attempt to measure it (Hanke \& Walters, 1997). According to Kešeljević (2013) it is clear that economic freedom is more present in capitalist than in socialist countries, and that nowadays the degree of economic freedom in some countries is higher than it used to be, but that these observations are not accurate enough suitable for scientific analysis and proof. In order to specify these differences and formulate an objective criterion for ranking economic freedom, it is necessary (a) to identify key elements of economic freedom (b) to quantify these elements (c) to assess the importance, or the weight, of these elements (Hanke \& Walters, 1997).

Several institutions and individuals have been compiling indices of economic freedom so as to identify its level of presence and rank countries based on the given criteria. The most sophisticated indices of economic freedom that have been devised and used in scientific circles are:

1. Freedom House Index

2. Scully and Slottje Index (1991)

3. Fraser Institute Economic Freedom Index

4. Economic Freedom Index of the Heritage Foundation

\section{Freedom House Index}

Although there had been earlier attempts, it can be said that the first attempt to systematically measure economic freedom was made in 1983 by Gastil and Wright (Gastil, 1984) under the cloak of Freedom House. The process of calculating political and civil liberty was upgraded with 
Ivana Brkić

data on the economic system, after which the countries were ranked. Such an index contained the protection of property rights, freedom of doing business and freedom from corruption. Friedman (1988) then carried out the first research on the correlation of the given index with gross domestic product per capita and found that index growth by one unit led to a significant $49 \%$ increase in GDP per capita.

Over time, this indicator progressed and in 1996 evolved into the index of economic freedom, the results of which were published in the World Survey of Economic Freedom (Messick, 1996). The ranking of the economic freedom of 82 countries was carried out on the basis of six categories of freedom: possession of property, earning a living, running a business, investing one's own earnings, foreign trade, participating in the economic market. Each category was scored from 0 to 2 or 3 , and the sum of all individual categories represented the total index. There are several reasons why this index found less application in scientific studies. Although it was planned to continuously monitor the state of economic freedom, so far only one publication has been published for the period 1995-1996. More specifically, initially this index was not created to indicate the importance of economic freedom in the context of economic growth, but rather to emphasize the connection with the primary areas of research of Freedom House political rights and civil liberty. At the same time, taxation measures were not included in the calculation, and government spending is taken into account and treated as crucial only in the borderline cases of the categories of "mostly unfree" and "unfree" countries. Subjectivity in measurement, a small range in ranking, and the opacity of data sources have contributed to the index not becoming/remaining present in scientific circles.

\section{Scully and Slottje Index (1991)}

The authors who were among the first to devote themselves to monitoring economic freedom and studying its relation to economic growth are Scully \& Slottje (1991). These authors developed a 15-element index covering 144 countries. The categories that were monitored were freedoms of: foreign currency, property, movement, information, civil rights, classification of the economic system, print media, broadcast media, domestic and international travel, peacetime gathering, as well as freedom from work permits, from search without a warrant, from arbitrary 
Ivana Brkić

seizure of property and from military recruitment. The index covered only the year of 1980, and the results showed a positive link between economic freedom and prosperity.

\section{Fraser Institute Economic Freedom Index}

As explained by Hanke \& Walters (1997), many scholars and contemporaries agreed that the approach taken by Gastil \& Wright (Gastil, 1984) overestimates the political and civil freedom (at the expense of economic freedom). This is why many worked hard to develop an alternative indicator. The most prominent results were obtained by Gwartney et al. (1996), who published the survey Economic freedom of the world, 1975-1995in 1996. A particular contribution of this study is the wide time span due to the fact that economic freedom exerts beneficial effects on the economic well-being of the country after some time. Since 2000, the Fraser Institute has been publishing the annual report "Economic Freedom of the World", which reports on political and institutional support for economic freedom on the basis of the Economic Freedom Index. Economic Freedom Index of the Fraser Institute (EFW) currently ranks 157 countries (data for about 100 nations and territories are available from 1980 and for some countries as early as 1970). Forty-two data processed into twenty-four categories are used to construct the aggregate index, after which economic freedom was divided into five larger areas ${ }^{1}$ (Gwartney, Lawson \& Hall, 2015). Each of the indicators is ranked on a scale from 0 (no freedom) to 10 (complete freedom).

Table 2. Categories of Fraser Institute Economic Freedom

\begin{tabular}{|l|ll|}
\hline & $>$ & Government spending \\
Size of & $>$ & Transfers and subsidies \\
government & $>$ & Government enterprises and investment \\
& $>$ & Top marginal tax rate \\
& & \\
& & - Top marginal income tax rate \\
& $>$ & Judicial independence \\
Legal system and & $>$ & Impartial courts \\
property rights & $>$ & Protection of property rights \\
& $>$ & Military interference in rule of law and politics \\
& $>$ & Integrity of the legal system \\
\hline
\end{tabular}

${ }^{1}$ During the development of the index, the names and numbers of the areas were changed, and care should be taken when analyzing reports and papers from different periods. 
Ivana Brkić

\begin{tabular}{|c|c|}
\hline & $\begin{array}{l}>\text { Legal enforcement of contracts } \\
>\text { Regulatory costs of the sale of real property } \\
>\text { Reliability of police } \\
>\text { Business costs of crime }\end{array}$ \\
\hline Sound money & $\begin{array}{l}>\text { Money growth } \\
>\text { Standard deviation of inflation } \\
>\text { Inflation: most recent year } \\
>\text { Freedom to own foreign currency bank accounts }\end{array}$ \\
\hline $\begin{array}{l}\text { Freedom to trade } \\
\text { internationally }\end{array}$ & $\begin{array}{l}>\text { Tariffs } \\
\text { - Revenue from trade taxes (\% of trade sector) } \\
\text { - Mean tariff rate } \\
\text { - Standard deviation of tariff rates } \\
>\text { Regulatory trade barriers } \\
\text { - Non-tariff trade barriers } \\
\text { - Compliance costs of importing and exporting } \\
>\text { Black-market exchange rates } \\
>\text { Controls of the movement of capital and people } \\
\text { - Foreign ownership / investment restrictions } \\
\text { - Capital controls } \\
\text { - Freedom of foreigners to visit }\end{array}$ \\
\hline Regulation & $\begin{array}{l}\checkmark \text { Credit market regulations } \\
\text { - Ownership of banks } \\
\text { - Private sector credit } \\
\text { - Interest rate controls / negative real interest rates } \\
\checkmark \text { Labor market regulations } \\
\text { - Hiring regulations and minimum wage } \\
\text { - Hiring and firing regulations } \\
\text { - Centralized collective bargaining } \\
\text { - Hours regulations } \\
\text { - Mandated cost of worker dismissal } \\
\text { - Conscription } \\
\checkmark \text { Business regulations } \\
\text { - Administrative requirements } \\
\text { - Bureaucracy costs } \\
\text { - Starting a business } \\
\text { - Extra payments / bribes / favoritism } \\
\text { - Costs of tax compliance }\end{array}$ \\
\hline
\end{tabular}

Source: Gwartney, Lawson \& Hall (2015) 
Ivana Brkić

\section{Economic Freedom Index of the Heritage Foundation}

In cooperation with The Wall Street Journal, Heritage Foundation has been publishing Index of Economic Freedom - IEF every year since 1995. The four main areas group together a total of ten areas of economic freedom (Miller, Kim \& Holms, 2015):

Table 3. Categories of the Heritage Foundation economic freedom

\begin{tabular}{|l|l|}
\hline I.Rule of law & II. Limited Government \\
\hline 1. Property rights & 1. Fiscal freedom \\
\hline 2. Freedom from corruption & 2. Government spending \\
\hline III. Regulatory efficiency & IV. Open markets \\
\hline 1. Business freedom & 1. Trade freedom \\
\hline 2. Labor freedom & 2. Investment freedom \\
\hline 3. Monetary freedom & 3. Financial freedom \\
\hline
\end{tabular}

Source: Miller, Kim \& Holms (2015)

Economic freedom is measured on the basis of an unweighted average of ten indices of individual freedoms. The achieved level of economic freedom for each country is then read out based on a defined scale, at which a value close to zero indicates a "repressed" economy (below 50 points on the scale) and then through "mostly unfree" (50-59.9), "moderately free" (60 - 69.9) and the "mostly free" economy (70 - 79.9) we get to a higher level of scale (80 - 100) which represents a "free" economy. Over the years, the Heritage Foundation has been increasing the number of countries it observes, so from the initial 101 in 1995, twenty years later, a total of 178 countries are "indexed" according to the criterion of economic freedom.

In the 2017 report, the Heritage Foundation made some methodological changes, and in the future 12 elements of economic freedom will be monitored, unlike the current 10 . The new component is Judicial Effectiveness, which belongs to the pillar of the Rule of Law and Fiscal Health as a new factor of the Government Size pillar. With these changes, all four pillars of the Economic Freedom Index are now made up of three elements (Table 4). 
Ivana Brkić

Table 4. Categories of the Economic Freedom Index of the Heritage Foundation that have been in use since 2017

\begin{tabular}{|l|l|}
\hline I.Rule of law & II. Government size \\
\hline 1. Property rights & 1. Tax burden \\
\hline 2. Government integrity & 2. Government spending \\
\hline 3. Judicial effectiveness & 3. Fiscal health \\
\hline III. Regulatory efficiency & IV. Open markets \\
\hline 1. Business freedom & 1. Trade freedom \\
\hline 2. Labor freedom & 2. Investment freedom \\
\hline 3. Monetary freedom & 3. Financial freedom \\
\hline
\end{tabular}

Source: Miller \& Kim (2017)

The former component Freedom from Corruption was refined and enriched with additional sub-factors and more thorough data sources that are much more extensive, and subsequently renamed to "Government Integrity". Fiscal freedom also underwent a cosmetic change and is now called "Tax Burden", to make it more explicit about what this component is and what it measures.

Of these four Indices of Economic Freedom, applied by scholars, policy makers as well as international organizations, the most prominent are the two, the Index of the Fraser Institute and The Index of the Heritage Foundation/the Wall Street Journal, primarily due to the continuity of monitoring the state and promptness in publishing the index.

Heckelman (2000) points out that the greatest advantage of the Economic Freedom Index of the Heritage Foundation is reflected in the institutional measures for the formation of the index, i.e. monitoring the effectiveness of certain policies, which may signal to authorities whether the given policies are appropriate and in the service of increasing economic freedom. On the other hand, the Fraser Institute predominantly uses macroeconomic indicators to construct its index, which is a consequence, not a cause, and therefore cannot directly serve economic policy makers.

Although they have data longer than the Heritage Foundation, the Fraser Institute has only been publishing annual reports on the state of economic freedom since 2000 (previous indices were presented for an interval of five years), which is why the Heritage Foundation is now at an advantage. On the other hand, this advantage may take the form of a disadvantage 
Ivana Brkić

when considering the effects common to business cycles that have no relation to economic freedom. Heckelman (2000) also praises the consistency in the ranking system of the Heritage Foundation, which the Fraser Institute has somewhat lost in its desire to improve the index itself, and some data are inconsistent and therefore unusable for long-term analysis. Today, it can be said that the Index of the Heritage Foundation also underwent minor changes, but a clear parallel can be drawn with respect to the earlier construction. Thus, Fiscal freedom originates from "Taxation" but kept an analysis of the same area - the amount of corporate and income taxes. "State interventions in the economy" turned into Government spending sub-index, still tracking the share of state ownership and the size of government spending. "Regulations" are expressed through Business freedom dimension, for the formation of which data are taken from the World Bank's annual report "Doing Business". Labor freedom, which has been included in reports since 2005, was analyzed in the "Wage-Price Control" sector, where the focus was on analyzing the existence of minimum wage laws, as well as government subsidies and the presence of price controls, which is today with an analysis of "Monetary Policy", the domain of Monetary freedom. Financial freedom was expressed by "Banking", and formed on the basis of regulations and share of state ownership in the banking sector. Investment freedom had the form of "Flows of capital and foreign investment", while the focus remains on monitoring and enhancing the equal treatment of foreign and domestic investors. Trade freedom or the former "Trade Policy" deals with comparing the level of tariff and (non)existence of non-tariff barriers. The new dimension was given to Freedom from corruption instead of the previous "Black Market", so now its status in the world is monitored based on the Corruption Perception Index, while the size of the black market is the domain of some other research. The scale according to which economic freedom was measured ranged from the first to the fifth level, with lower values implying less economic freedom, but for more precise definition since 2007 the scale has been expanded from zero to one hundredth value of the index.

As further stated by Heckelman (2000), data for the Fraser Institute index are often missing, which further obstructs the consistency of the database through monitoring different categories for different countries. The situation is similar with the Heritage Foundation index, but to a much lesser extent - their data are missing only for individual countries in the first years 
Ivana Brkić

of measurement, while later omissions were only observed in countries where there is a current state of war or certain political and national problems.

While some authors (Ram, 2014; Pérez-Moreno \& Angulo-Guerrero, 2015) find differences in the country ratings of these two indices, the leading, relevant authors (De Haan \&Sturm, 2000; De Haan, 2003; Hanke \& Walters, 1997) point to the similarities of the Economic Freedom Index of the Heritage Foundation and the Fraser Institute. These authors prove this by the high level of the Kendall and Spearman's correlation coefficient between the two indices. The complementarity of these two parameters of economic freedom is also reflected in the equal importance they attach to institutions securing property rights, contract enforcement, support for the freedom of international exchange of goods and capital (Kešeljević, 2013), but also to other areas of economic liberalization. Thus, both indices negatively assess barriers to entry into the product and labor market, and the value on the scales also declines when price and wage control is observed (Hanke \& Walters, 1997). Finally, the focus of interest of both institutions is both fiscal and monetary policy: both indices negatively interpret large government spending and positively the measures taken to control inflation.

Table 5. Comparison of the Economic Freedom Index of the Fraser Institute and the Heritage Foundation

\begin{tabular}{|c|c|}
\hline Fraser Institute & Heritage Foundation/Wall Street Journal \\
\hline Size of Government & Limited Government \\
\hline $\begin{array}{ll}\checkmark & \text { Government spending } \\
\checkmark & \text { Transfers and subsidies } \\
\checkmark & \text { Government enterprises and investment } \\
\checkmark & \text { Top marginal tax rate } \\
& \checkmark \text { Top marginal income tax rate } \\
\checkmark & \text { Top marginal income and payroll } \\
& \text { tax rate }\end{array}$ & $\begin{aligned} \checkmark & \text { Fiscal freedom } \\
\checkmark & \text { Top marginal individual income } \\
& \text { tax rate } \\
\checkmark & \text { Top marginal corporate tax rate } \\
\times & \text { The overall tax burden as a } \\
& \text { percentage of gross domestic } \\
& \text { product }\end{aligned}$ \\
\hline Legal System and Property Rights & $\begin{array}{c}\text { Rule of Law } \\
\text { (Property Rights and Freedom from } \\
\text { Corruption) }\end{array}$ \\
\hline $\begin{array}{ll}\checkmark & \text { Judicial independence } \\
\checkmark & \text { Impartial courts } \\
\checkmark & \text { Protection of property rights } \\
\end{array}$ & $\begin{array}{ll}\checkmark & \text { Judicial independence } \\
\checkmark & \text { Judicial effectiveness } \\
\checkmark & \text { Protection of property rights } \\
\end{array}$ \\
\hline
\end{tabular}




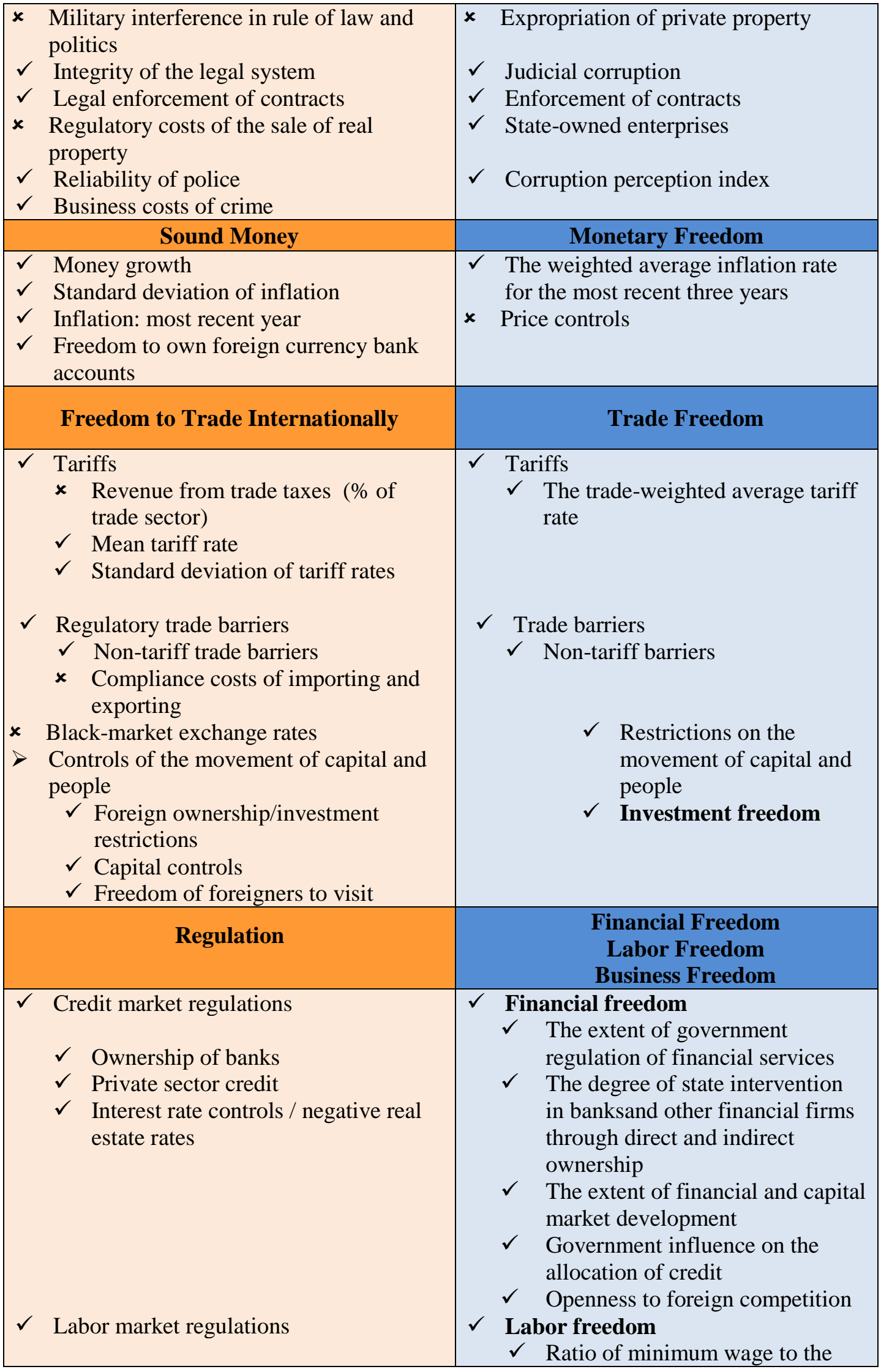


Ivana Brkić

\begin{tabular}{|c|c|c|}
\hline$\checkmark$ & $\begin{array}{ll}\checkmark & \text { Hiring regulations and minimum } \\
\checkmark & \text { wage } \\
\checkmark & \text { Hiring and firing regulations } \\
\checkmark & \text { Hours regulations } \\
\checkmark & \text { Mandated cost of worker dismissal } \\
\times & \text { Conscription } \\
& \\
\text { Business regulations } \\
\checkmark & \text { Administrative requirements } \\
\checkmark & \text { Bureaucracy costs } \\
\checkmark & \text { Starting a business } \\
\checkmark & \text { Extra payments / bribes / favoritism } \\
\checkmark & \text { Cost of tax compliance }\end{array}$ & 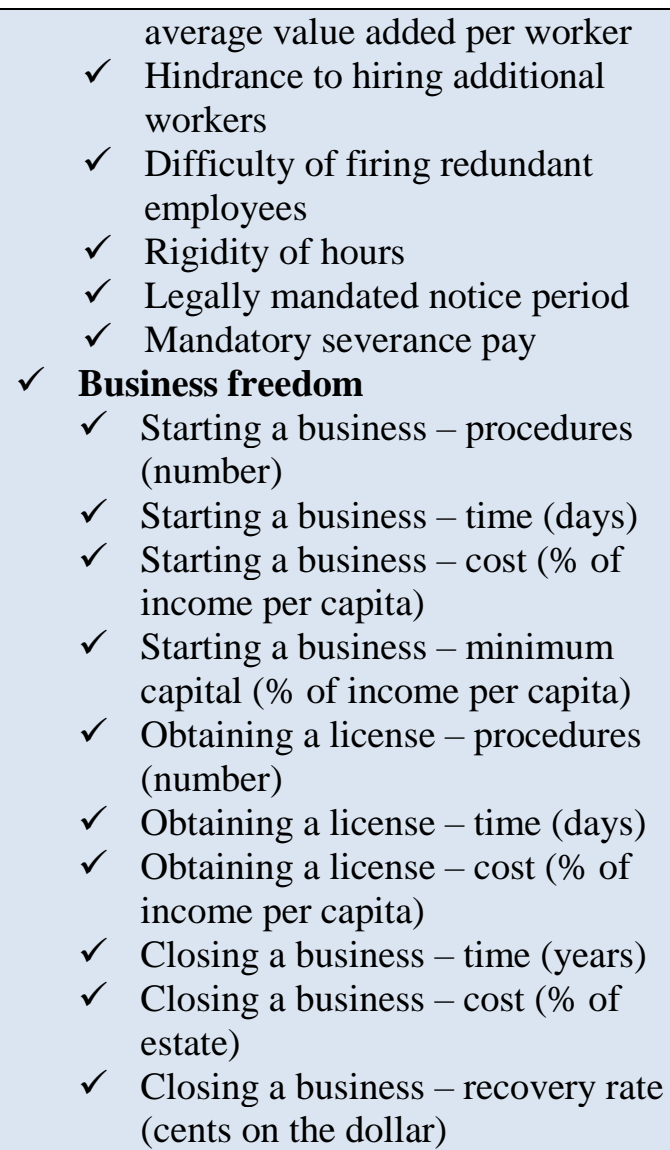 \\
\hline
\end{tabular}

Source: Author, adapted from Gwartney, Lawson \& Hall (2015) and Miller, Kim\&Holms (2015)

Kešeljević (2007, 2013) distinguishes between economic freedom as a subjective and objective category. If it represents a personal experience (whether the tax of $20 \%$ is high or low), it is subjective, while the objective one is defined by society. Without objective freedom, subjective freedom is not possible. The very act of determining the degree of satisfaction with a certain level of freedom implies the existence of freedom in itself as an objectively given category.

Kešeljević $(2007,2013)$ regards the absolute economic freedom of the individual as the absence of any obstacles, which is certainly not possible. Just as absolute freedom is actually shaped by education, public opinion, culture and values that govern one society, so is the restriction (and relativism) of economic freedom actually in the interest of preserving the freedom itself. 
Ivana Brkić

Individual freedom accepts the framework of collective freedom only in the case of society in the function of protecting the property rights of individuals. Collective economic freedom shows the extent to which the system reflects the will of the majority to create the form of political and economic system best suited to society (Kešeljević, 2013).

If we were to decide whether economic freedom is a negative (which implies the absence of any restriction) or a positive category (where individual control is visible, which requires a more active role of the state), we would have to admit that it is more characterized by the latter. It is the legal framework that limits the concrete and uncontrolled actions of individuals, thereby giving economic freedom a positive character (Kešeljević, 2013).

Finally, Kešeljević (2013) classifies different views and interpretations of economic freedom by institutions (Table 6).

Table 6. Similarities and differences in the interpretation of categories of economic freedom

\begin{tabular}{|c|c|c|c|}
\hline \multirow{2}{*}{ Economic freedom } & \multicolumn{3}{|c|}{ Index of economic freedom } \\
\hline & Fraser & Heritage & Freedom House \\
\hline \multicolumn{4}{|l|}{ Subjective } \\
\hline Objective & $\sqrt{ }$ & $\sqrt{ }$ & $\sqrt{ }$ \\
\hline Absolute & $\sqrt{ }$ & $\sqrt{ }$ & $\sqrt{ }$ \\
\hline \multicolumn{4}{|l|}{ Relative } \\
\hline Collective & & & $\sqrt{ }$ \\
\hline Individual & $\sqrt{ }$ & $\sqrt{ }$ & \\
\hline \multicolumn{4}{|l|}{ Positive } \\
\hline Negative & $\sqrt{ }$ & $\sqrt{ }$ & $\sqrt{ }$ \\
\hline
\end{tabular}

Source: Kešeljević (2013)

From the perspective of the subject of research of this doctoral dissertation, the arguments about the high similarity between the leading two indices of the Fraser Institute and the Heritage Foundation speak in favour of the fact that the results of the study on the impact of economic freedom on economic growth are not dependent on the choice of indicators (indices) of economic freedom. The selection of the Economic Freedom Index of the Heritage Foundation for the purpose of the research into the impact on the economic growth of a European group of countries was made partly because of the methodology, the availability of a wealth of data and the wide application in previous research. 
Ivana Brkić

\subsubsection{CHAPTER SUMMARY}

In order to follow the chronology of the development of economic thought from the aspect of economic freedom, the previous chapter analyzes the concept of economic freedom, dating back to the time of Adam Smith, who already came to the conclusion in 1776 that an institutional environment deprived of excessive control by countries is a determinant of economic growth. On the other hand, history tells us that in the past there have been periods when instead of the invisible, the hand of salvation was sought from the state. Therefore, it was discussed whether economic freedom is the cause of economic growth but also of economic crises, or whether crises just arose because of the lack of complete liberalization in all domains of the economy. In order to understand this, we have analyzed various scientific approaches to the optimal degree of market regulation, the role of the state and the importance of a free market and a competitive environment for stimulating economic growth. Undoubtedly, appropriate policy and economic institutions liberalizing the market are at the service of a positive growth rate. Although there is no general definition and unique view, it is clear that economic freedom, that is, the freedom of people to work and freely manage their property - without compromising the rights of others is a defining determinant of economic growth. In this context, the role of the state is "reduced" to the protection of property and the enforcement of contracts, without which economic freedom would be practically impossible. In order to quantify economic freedom and thus more precisely determine its impact on economic growth, several economic freedom indices were created, best-known of which are the Freedom House Index, the Scully and Slottje Index (1991) constructed by the Fraser Institute and the Heritage Foundation Economic Freedom Index, whose structures were briefly presented and explained in this chapter. As the Heritage Foundation's Freedom Index data were used in the empirical part of the dissertation, the following chapter gives a detailed theoretical interpretation, outlines its concept and explains in detail the components of the said index. 
Ivana Brkić

\subsection{CONCEPT OF THE ECONOMIC FREEDOM INDEX OF THE HERITAGE FOUNDATION}

\subsubsection{INTRODUCTION}

This chapter presents the Economic Freedom Index, published by the Heritage Foundation in collaboration with the Wall Street Journal for the past 25 years, or since 1995. Its structure is shaped by four pillars that group a total of ten areas of economic freedom (Miller, Kim \& Holms, 2015). The first pillar is Rule of Law, which is constructed by the sub-indices Protection of Property Rights and Freedom from Corruption, within which judicial independence, effectiveness of enforcement of laws and contracts, and the presence of corruption in all segments of society are analyzed. The second pillar -Limited Government, monitors the state of Fiscal Freedom through the extent of tax burden and Government Spending in the observed countries. Regulatory efficiency is the third pillar of economic freedom dedicated to the aspects of Business Freedom, Labor Freedom and Monetary Freedom, used to measure the extent of bureaucratic constraints in the business process, the degree of regulation in the labor market and the stability of prices formed in the market. The fourth pillar of Market Openness, expressed through Trade Freedom, Investment Freedom and Financial Freedom, is dedicated to examining the openness and presence of international trade in goods, services and money, as well as the presence of foreign and domestic investors and financial institutions, operating independently of state control. A detailed methodology for constructing each sub-index and their aggregation into a single index of economic freedom will be presented further in this chapter.

\subsubsection{THEORETICAL INTERPRETATION OF THE ECONOMIC FREEDOM INDEX}

According to Cole (2003), Index of Economic Freedom of the Hermitage Foundation highlights a broad set of variables in the domain of economic policy, known to affect economic efficiency: inflation rate, taxes, public spending, public enterprises, government investment, tariff rates, trade barriers, price controls, distortions in the labor and capital markets, etc. The negative effects of these policies induce disruptions that have a chain effect on the entire 
Ivana Brkić

economy. There is also a high level of correlation (countries with bad policies tend to be consistently bad in many domains of economic policy), so it is difficult to define separate effects. However, one thing is for sure: bad policies have a negative impact on economic growth, and improving them can significantly improve growth. The Economic Freedom Index is a report on a country's overall economic policy (with recommendations for better assessment). Economic policy makers should certainly keep in mind the forecasts of these indices.

\subsubsection{THEORETICAL INTERPRETATION OF THE ECONOMIC FREEDOM SUBINDICES}

Economic freedom, as defined by the Heritage Foundation, implies rule of law, limited government, regulatory efficiency and market openness. These are also the four basic pillars of the Index of Economic Freedoms, each grouping sub-indices that follow specific aspects of economic freedom in their domain. The following is an overview of the methodology for calculating the value of each economic freedom sub-index as stated on the Heritage Foundation website (http://www.heritage.org/index/). During 25 years how long this Index is producing, its methodology has been improved in scope and scientific rigor (Miller, Kim \& Roberts, 2019).

\section{Rule of Law}

\section{Property rights}

Legal protection of property is an important requirement for the business environment, which supports innovation, entrepreneurship and therefore economic growth. For this reason, the sub-index property rights monitors how much the laws of a state protect private property and the extent to which the government enforces the enacted laws. The sub-index analyzes the independence of the judiciary, the existence of corruption in the judiciary and the ability of individuals and businesses to enforce contracts.

Each country is rated on a scale from 0 to 100 , where a higher number reflects a country where private ownership is guaranteed by the government, the judicial system promptly and effectively 
Ivana Brkić

enforces contracts and penalizes those who illegally seize private property, where there is no corruption or expropriation. The lower scores represent a country where most property belongs to the state, expropriation is commonplace, the judiciary so corrupt that private property is poorly protected, and property rights are difficult to enforce.

\section{Freedom from corruption / Government Integrity}

Although no society is immune to corruption, there are significant differences in its extent. In some countries, the rule of law minimizes corruption, while in others it is incorporated into the bureaucratic and political system. Freedom from corruption is therefore the aspiration of each economically free state. The formation of the sub-index "freedom from corruption" is based on Transparency International's Corruption Perceptions Index (CPI). The Corruption Perceptions Index is based on a 10-point scale where 0 represents a highly corrupt government. For the formation of the Freedom from Corruption sub-index, the resulting index is multiplied by 10, so that a country whose corruption perceptions index is 8.5 will have "freedom from corruption" 85 . The renaming of the Freedom from Corruption subindex into Government Integrity also led to a methodological change in the calculation of this element of economic freedom (although we insisted that we provide an interpretation for the formation of the former subindex, since most of the data in the survey sample was created in this way). In other words, the newly created subindex of Government Integrity primarily expanded the list of sources on the basis of which it is formed and thus complexify the formula for calculating it, and it now reads:

Sub-factor Score i = 100 x (Sub-factorMax-Sub-factor i)/(Sub-factorMax-Sub-factorMin)

where Sub-factor i represents the original data for country i; Sub-factorMax and Sub-factorMin represent the upper and lower bounds for the corresponding data set; and Sub-factor Score $\mathrm{i}$ represents the computed sub-factor score for country $i$.

What the above data from different sources cover (a detailed list of sources can be found in the methodology section Miller, Kim \& Roberts (2019)) is equally weighted following subfactors: Transparency of government policymaking, Public trust in politicians, Perceptions of corruption, 
Ivana Brkić

Irregular payments and bribe, Governmental and civil service transparency and Absence of corruption.

\section{Limited Government}

\section{Fiscal Freedom / Tax Burden}

Limited government is monitored in terms of revenue and expenditure of a state. Thus, government constraints in terms of revenue are viewed through fiscal burden it imposes on its citizens and the economy. Fiscal freedom is viewed through three equally valued factors: the top marginal tax rates on individual income, the top marginal tax rates on corporate income, and the total tax burden as a percentage of gross domestic product. Index creators use the quadratic cost function in formula (2) to calculate fiscal freedom so as to express the declining tax revenue caused by rising tax rates.

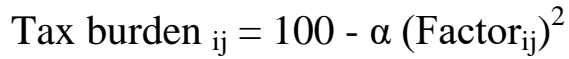

Fiscal freedom $\mathrm{ij}_{\mathrm{j}}$ is fiscal freedom in countryi for factor $j$, while Factor $_{\mathrm{ij}}$ is the value of factor in country $i$ for factor $j$. $\alpha$ is coefficient set equal to 0.03 . The score for each factor is individually obtained on a scale of 100 points, after which the average for obtaining the fiscal freedom subindices is calculated.

Although this indicator does not measure relative tax burden, that is, how much government provides benefits to taxpayers through public spending, fiscal freedom is an important aspect of a free, market economy, according to index creators.

\section{Government spending}

Government spending is measured through the amount of public expenditure and transfers, expressed as a percentage of gross domestic product. In the scientific literature, there is no consensus on whether a reduction in government spending leads to progress or an even deeper crisis. In analyzing the impact of economic freedom, from the point of view of government spending, certain authors (eg Altman, 2008) suggest efficient, not necessarily reduced, government spending to achieve good results. 
Ivana Brkić

The creators of the Economic Freedom Index have not defined the optimal level of public spending and do not necessarily proclaim low government spending, but guided by the results of numerous studies, they came to a conclusion that excessive public spending leads to chronic budget deficits, rising public debt and declining economic activity. Because of this, they treat zero public spending as a benchmark that should be aspired to. This way they make an intentional methodological omission as a result of which economically underdeveloped countries, without the financial capacity for large public spending, are positively assessed. The authors of the index justify the idea with lower ratings in other categories of freedom that these countries will "certainly" record.

The equation for obtaining the sub-index government spending is non-linear to achieve the effect that countries with zero public spending are "penalized" less than those with spending in excess of $30 \%$ of gross domestic product.

The sub-index Government expenditure $\left(\mathrm{GE}_{\mathrm{i}}\right)$ is calculated using Equation (3).

$\mathrm{GE}_{\mathrm{i}}=100-\alpha\left(\text { Expenditures }_{\mathrm{i}}\right)^{2}$

Expenditure of country $i$ represents the total government spending of the country at all levels (federal, state, local) as part of the gross domestic product (between 0 and 100), while $\alpha$ is a coefficient to control the variation among scores and is set at 0.03 .

\section{Regulatory efficiency}

\section{Business freedom}

Perhaps the most obvious proof of the existence of a free economy is the efficiency of the business environment, that is, a short period of time and quick procedures to set up, operate and close a business. It is the embodiment of entrepreneurship and pace that the modern world dictates. This way, through the sub-index "business freedom", the government's regulatory efficiency is confirmed. The sub-index is obtained on the basis of ten equally valued sub-factors: the number of procedures and the number of days required to start a business, the cost of starting a business in relation per capita income, and the minimum capital required to start a business viewed as a percentage of income per capita; number of days, procedures and costs relative to per capita income for obtaining a license; number of years to close a business, costs of closing a 
Ivana Brkić

business(as a percentage of estate) and recovery rate (cents on the dollar) upon closing a business. Each of these sub-factors is converted to a value on a scale from 0 to 100, after which the average value of the newly obtained values is calculated based on formula (4).

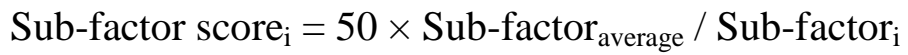

The score of the converted factor for a given country is based on the ratio of the country factors based on World Bank data relative to the world average multiplied by fifty. Finally, a final assessment of business freedom is obtained by calculating the average of all ten factors. If a country is not covered by the World Bank's Doing Business report, relevant qualitative data from reliable and internationally recognized sources are used.

\section{Labor Freedom}

Labor Freedom category is a measure that considers various aspects of the legal and regulatory framework of a country's labor market. The sub-index includes six components: the ratio of the minimum wage to the average value added per worker, hindrance to hiring additional employment, rigidity of hours, difficulty of redundant employees, legally mandated notice period and mandatory severance pay. This sub-index was included in the index calculation in 2005 due to the unavailability of qualitative data before that time. Since 2009 , the components of labor freedom have included six instead of the previous four factors.

Similar to the business freedom category, each of these segments is converted to a scale of 0 to 100 using an equation where that country data are calculated relative to the world average and then multiplied by fifty.

Sub-factor score $_{i}=50 \times$ Sub-factor $_{\text {average }} /$ Sub-factor $_{\mathrm{i}}$

The average of the six values converted gives the overall labor freedom score. This can be both an advantage and a disadvantage: although a country has the worst conditions considering one of the criteria, it could still have a high score based on the remaining five factors.

\section{Monetary Freedom}

Monetary freedom is used to measure price stability and the absence of price controls by the state. These are some of the main prerequisites for business stability and the functioning of the 
Ivana Brkić

free market. Although there is no consensus on the choice of monetary policy that will ensure a free and economically prosperous society, there is widespread opinion about the benefits of low inflation and central bank independence, as well as the negative effects of price controls leading to market surpluses or shortages (Miller \& Kim, 2013).

Sub-index monetary freedom is obtained on the basis of two sub-factors: the average weighted average inflation rate for the most recent three years and the qualitative price control measures, which is a negative score, and is subtracted from the result obtained. The average weighted inflation rate for the most recent three years is the base, from which "penalty points" are later deducted in the range of 0 to 20. Monetary freedom base is derived based on the formula (6):

Weighted average inflation $_{\mathrm{i}}=\theta_{1}$ Inflation $_{\mathrm{it}}+\theta_{2}$ Inflation $_{\text {it-1 }}+\theta_{3}$ Inflation $_{\text {it-2 }}$

In formula (6), $\theta_{1}, \theta_{2}, \theta_{3}$ represent three numbers that sum to 1and are exponentially smaller in sequence (e.g. $0.665,0.245,0.090$ respectively), thus giving greater importance to the newer inflation rate. Inflation ${ }_{i t}$ represents the annual rate of inflation in the country $i$ and in year $t$, as measured by the Consumer Price Index.

Formula (7) is then used to calculate the final subindex:

${\text { Monetary } \text { freedom }_{i}=100-\alpha \sqrt{ } \text { Weighted average inflation }_{i}-\text { PC penalty }}_{i}$

In formula (7), $\alpha=6.333$ represents the coefficient for stabilizing the variance of results (i.e.it converts the percentage of inflation into the value of sub-index on a scale from 0 to 100 . For greater accuracy, the square root of the weighted average inflation rate is used. PC penalty represents penalties for price control by the state, which range from 0 to 20 and are subtracted from the monetary freedom sub-index base to obtain the final score.

\section{Open Markets}

Open markets are achieved through free trade, financial freedom and freedom of investment.

\section{Trade Freedom}

Trade freedom is achieved through the absence of tariff and non-tariff barriers, which affect the export and import of goods and services, which reduces costs, increases efficiency and the comparative advantage of all countries. 
Ivana Brkić

Trade freedom is assessed on the basis of the trade-weighted average tariff rate and non-tariff barriers. As different goods are burdened with different tariff rates, the importance of each individual rate is determined on the basis of the share of imports of individual goods in total imports.

Thus, the sub-index trade freedom is obtained by the formula (8).

Trade Freedom $=\left(\left(\left(\operatorname{Tariff}_{\max }-\right.\right.\right.$ Tariff $\left._{\mathrm{i}}\right) /\left(\right.$ Tariff $_{\max }-$ Tariff $\left.\left.\left._{\min }\right)\right) * 100\right)-\mathrm{NTB}_{\mathrm{i}}$

where Trade Freedom ${\text { represents the sub-index trade freedom in country } i, \text { Tariff }_{\max } \text { and Tariff }}_{\min }$ represent the upper and lower bounds for tariff rates (expressed in \%) and Tariff $f_{\mathrm{i}}$ represents the weighted average tariff rate in countryi. The lower limit is the rate of $0 \%$ and the upper $50 \%$ of the value of imported goods. $\mathrm{NTB}_{\mathrm{i}}$ represents the non-tariff barrier of the country $i$ and is subtracted from the base score in the form of a penalty to obtain the final score. The penalty may be $0,5,10,15$ or 20 points, depending on the frequency of use of non-tariff barriers (20 for barriers that completely impede international trade due to extensive use across most goods and services). Determination of the number of points that will be deducted on account of non-tariff barriers depends on qualitative and quantitative information on the types of restrictions, the most important of which are: quantity restrictions, price restrictions, regulatory restrictions, investment and customs restrictions as well as direct government intervention.

\section{Investment Freedom}

In an economically free country, which would receive a score of 100 on the Investment Freedom component, there would be free flow of investment capital, that is, free movement of resources of individuals and companies, both internally and across the country's borders. In practice, however there are different restrictions on investment: different treatment of foreign in relation to domestic investment, legal and bureaucratic difficulties for foreign investors, restrictions considering land ownership, investment restrictions for certain sectors, expropriation of investment without fair compensation, foreign currency control, capital control. For different levels of these restrictions, 5, 10, 15, 20 or 25 points are deducted from the ideal score depending 
Ivana Brkić

on the extent and intensity of the restrictions. In addition to these restrictions, up to 20 additional penalty points may be deducted for security problems, a lack of basic investment infrastructure, corruption, or other government policies that burden the investment process and limit investment freedom.

\section{Financial Freedom}

Financial freedom is a measure of banking efficiency and independence from state control and interference in the financial sector. The role of the state should be reduced to the implementation of contractual obligations and the prevention of fraud. The state should not own financial institutions (since that way it leads to reduced competition), and foreign institutions of this type should act equally in the market with the domestic ones. Five broad areas are followed for the formation of the sub-index financial freedom: the extent of government regulation of financial services, the degree of state intervention in banks and other financial firms through direct and indirect ownership, the extent of financial and capital market development, government influence on the allocation of credit and openness to foreign competition.

Full financial freedom is achieved in a situation where the financial sector of a country has minimal state influence and prices for various financial services are formed on the basis of market conditions. This should enable the population and the economy to have easy and effective access to funding opportunities.

The 100-point index value reflects an independent financial sector with minimal government influence. By increasing the government's influence on financial institutions, the result drops by 10 points. The minimal score that a country can achieve is zero and reflects a repressive government whose financial policy is formulated to prevent or completely ban private financial institutions. 
Ivana Brkić

\subsubsection{CHAPTER SUMMARY}

This chapter presents a way of constructing the Economic Freedom Index of the Hermitage Foundation to give a clear picture of what it covers, given that its data were used in the empirical part of the paper as an independent variable whose impact on economic growth was sought to be examined. The Economic Freedom Index covers all areas that are known to affect the economic prosperity of a country / area. The Economic Freedom Index is used to analyze the protection of property rights, the extent of corruption, the fiscal system in terms of tax burden but also the amount of public spending, ease of doing business and work, inflation rate, the burden of international trade with tariffs and taxes, the functioning of the investment and financial sectors.

Quantifying the elements of economic freedom is important in order to determine the impact that such a form of organization of economy and society has on economic prosperity, as well as many other segments of life. The next chapter will be devoted to reviewing the scientific literature, which has broadly and narrowly addressed the study of the relationship between economic freedom as well as its components and economic growth in different groups of countries. 
Ivana Brkić

\subsection{ECONOMIC FREEDOM AS A SUBJECT OF SCIENTIFIC RESEARCH}

\subsubsection{INTRODUCTION}

For a long time it had been a problem how to identify and measure economic freedom so that it could be correlated with various economic contributions. In this context, many studies could be challenged as regards their scientific contribution, as scholars have been so far handicapped by insufficient and incomplete data on the state of economic freedom. This opportunity has been increasing year by year, so today it is possible to measure economic reality and test different hypotheses. According to the authors and creators of indicators of economic freedom, the indices themselves do not aspire to determine which level of economic freedom is optimal. It is the task of scholars to address whether a greater or increasing level of economic freedom contributes to economic growth.

Although this is a relatively new topic and area for exploration, by 2011, a total of 402 scientific papers had been published in 211 reputable international journals on economic freedom, as stated by the authors of the Index of Economic Freedom of the Fraser Institute, Hall \& Lawson (2014). These works have been cited over 4,000 times. A total of 737 scientists have dealt with this problem, while 9 out of 15 scientists who published works are from the European area. In almost all studies, the economic freedom index is used as an independent variable. The influence of the economic freedom index on various macroeconomic variables was dominantly studied: level and growth of GDP, income level, poverty, productivity and investment, but wars, human rights, gender equality, number of supermarkets, performance at the level of company, etc. were also the dependent variables. Two thirds of these studies concluded that the index of economic freedom correlated with "good" dependent variables (GDP growth, investment growth, peace, human rights); $28 \%$ received indeterminate results, and in only $4 \%$ of the studies the index correlated with "bad" indicators. The negative consequences of the growth (index value) of economic freedom relate mainly to the growth of economic inequality, which comes as the price of economic freedom. Concerning controversial or not clearly defined results when analyzing individual parts of economic freedom, Hall \& Lawson (2014) state that "the whole is greater than the sum of its parts" in terms of the index and that its overall contribution should be considered. 
Ivana Brkić

Many studies sought to unravel the nature of the link between economic freedom and economic growth. Using various econometric methods as well as different indicators of economic freedom, everyone tried to answer the same question: does economic freedom lead to economic growth? Some found a positive relationship, others negative, and for some the relationship showed no statistically significant results. There have been numerous studies that have sought to determine which segment of economic freedom is most conducive to growth in order to create an appropriate economic policy that would improve the area and thus contribute to economic prosperity. Two scientific currents were also grouped together in an attempt to discern whether the level or change in the level of economic freedom was responsible for growth. The subject of the research was also to discover the nature of the relations between the degree of democracy, political, civil and economic freedom, and their direct or indirect influence on growth. There were different groups of countries, as well as the criteria and reasons for grouping, while certain scholars focused only on one country trying to determine its specificities in terms of economic freedom and its contribution to growth.

Below is an overview of the most important scientific breakthroughs in the study of the relationship between economic freedom and economic growth.

\subsubsection{EXAMINING THE RELATIONSHIP BETWEEN ECONOMIC FREEDOM AND ECONOMIC GROWTH}

Among the first authors to investigate the link between economic freedom and growth was Islam (1996). Based on a report by the Fraser Institute (Easton \& Walker, 1992), the author conducted research on a sample of 94 countries, of which 28 were low, 43 middle and 23 highincome countries, covering the period 1980-1992. He observed how economic freedom affects the formation of the level of gross national product as well as its growth (two dependent variables). He noted that high-income countries have a high degree of economic freedom whereas low-income countries are characterized by a low level of free economy. Nevertheless, regression showed that lower levels of economic freedom have the effect of reducing per capita 
Ivana Brkić

income levels in low-income countries, while this is not the case in high and middle-income countries (the results are not statistically significant). The unified set of countries is characterized by a positive link between economic freedom and the level of gross national product (GNP). Contrary to the previous calculation, a decrease in the degree of economic freedom in highincome countries has the effect of slowing down economic growth, while this is not reflected in middle and low-income countries. Similar to the previous result, a sample in which all countries were covered shows a positive impact of economic freedom on economic growth. The author also concludes that the growth of income levels in all countries, especially those with low levels, leads to the increase in the degree of economic freedom. Islam (1996) opens the possibility of different results when more appropriate methods of analysis such as panel based analysis are applied, but justifies his choice of the so-called cross section analysis with the unavailability of time data. Ten years later, Islam \& Salimullah (2006) conducted a panel analysis and confirmed that in countries with low per capita income, economic freedom has positive effects on economic growth.

A large number of published studies gave different, sometimes contradictory or inconsistent conclusions on the relationship between economic freedom and economic growth. Some studies show that there is no robust link, while others prove the link between economic growth and only certain aspects of economic freedom. Therefore, it is very difficult to determine the quality and credibility of each study. As a result, Doucouliagos \& Ulubasoglu (2006) sought to prove the hypothesis of the link between economic growth and economic freedom using metaanalysis as a quantitative synthesis of empirical research based on available literature. The analysis covers the processing of 48 studies examining the relationship between economic freedom and economic growth (as well as the impact of freedom on investment, as an indirect initiator of growth). Authors of all studies used regression and published correlation coefficients, T-statistics, and standard error, and these were therefore selected as suitable for the application of meta-analysis in order to find possible regularities in the relationship between economic freedom and growth. The authors processed three sets of data. The first group includes one calculation from each study (within which all papers are statistically independent, which means that different authors did not analyze the same set of data, nor did the same authors use different set of data when making their average), thus the analysis included45 observations. The second 
Ivana Brkić

group takes more calculations that were published in the same paper (if the analysis was done for two groups of countries, etc.), hence a total of 62 observations were included. The third group includes 111 calculations whose models include subcomponents of the index as separate entities. The results of the meta-analysis confirm a positive direct link between economic freedom and economic growth, as well as a positive indirect effect on economic growth through stimulation of physical investment. Yet, the results also show shortcomings of these studies, which are reflected in the following. The presence of poor specifications of models that are applied in the regressions is clear. The selection of an appropriate production function, which will encompass both human and physical capital, which equally affect the growth (as demonstrated by Mankiw, Romer, \& Weil, 1992) is the author's recommendation for future research. This way the disadvantages of sensitivity analysis can be overcome in many studies (Sturm \& De Haan, 2001). The so-called publication bias was also noticed. This refers to the publication of (only those) results of studies that confirm a statistically significant link between growth and economic freedom (as opposed to studies that find such a link insignificant or negative). In order to meet the set theoretical expectations, scientists change models and/or use different statistical techniques, which distorts the picture of the real impact of economic freedom on economic growth.

In the subsequent paper, which included 52 studies using the same method, Doucouliagos (2005) concludes that there is less publication bias in the research group that analyzes the impact of components of the economic freedom index on economic growth. He also points to a larger publication of those papers that do not produce theoretically desirable results, in order to give the public a real insight into the nature of the relationship economic freedom - growth. Other than the positive, economic freedom may be likely to have a negative or statistically insignificant correlation coefficient with growth, as demonstrated in the case of the correlation between democracy and economic growth, according to Doucouliagos (2005). 
Ivana Brkić

\subsubsection{EXAMINING THE RELATIONSHIP BETWEEN DIFFERENT COMPONENTS OF ECONOMIC FREEDOM AND ECONOMIC GROWTH}

The first published paper that analyzed the link between different dimensions of economic freedom and economic growth was published by Ayal \& Karras (1998). The authors made a significant contribution by decomposing the unique Fraser Institute index and noting the relationship between certain aspects of economic freedom and growth. This for the first time enabled economic policy makers to deduce which segments in particular to put emphasis on in formulating a strategy for advancing economic growth. The authors applied a neoclassical growth model (which includes the initial level of gross domestic product, share of investment in GDP and population growth rate) in a sample of 58 countries, within a time span of fifteen years (1975-1990). They concluded that growth was reflected by an increase in overall factor productivity and an increase in capital accumulation. They observed that all thirteen components of the Fraser Institute Economic Freedom Index show a positive correlation coefficient with growth, but six of them are statistically significant. They state that growth is achieved when (1) there is a low rate of growth of money and inflation, (2) when the role of state-owned enterprises is reduced, (3) when negative interest rates are rare, (4) when there is less difference between the official exchange rate and that of the black market (5) when trade occupies a significant part of the economy and (6) when citizens are free to engage in capital transactions with foreigners. Contrary to the authors' expectation, the level of tax rates, military service and tariff rate did not show a statistically significant effect on economic growth.

In view of the contradictory conclusions reached by earlier studies, Heckelman \& Stroup (2000) wish to contribute to finding and illuminating those aspects of economic freedom that do not affect economic growth as opposed to those that exhibit such a relationship. The authors prove that the total level of economic freedom of 1980 does not have a statistically significant relationship with economic progress from 1980 to 1990, and emphasize that this finding should not lead to the premature conclusion that economic freedom is not related to economic growth. Thus, using bivariate regression first, the authors investigate the impact on the economic growth of each individual element of economic freedom according to the Fraser Institute design at the time (Gwartney et al., 1996) to determine which aspects contribute to growth and which obstruct 
Ivana Brkić

it. Following the first results obtained, the authors apply multivariate regression to avoid multicorrelation between segments of economic freedom within the same group and to determine which aspect of freedom in a group of the similar contributes most to growth. They do this by retaining the constant values of the other subindices in the group. Based on the calculation, they conclude that only three out of the fourteen components have an independent impact on economic growth.

Thus, Group I (Money and Inflation: Protecting money as a medium of exchange and preserving value) and Group III (Levies and discriminatory taxes: Freedom to keep what is earned) show a negative link to growth, while Group II (Government Regulation: Freedom to decide about what to produce and buy) and Group IV (Restrictions on international exchange: Freedom of exchange with foreign countries) have a positive relationship with growth, according to authors Heckelman and Stroup (2000) based on the results of bivariate regression analysis. Group IV makes the strongest contribution to growth, with the most important aspect being the "Difference between the official and black market exchange rates" within the same group. After initiating multivariate regression, only this aspect retains a positive and significant impact on growth, which means that the other segments in Group IV are highly correlated with the former (and it is the one that actually has the greatest impact on economic growth). The marginal tax rate maintains a negative, statistically significant relationship with economic growth, and Transfers and subsidies gain statistical significance after a multivariate regression. Both of the aforementioned components of economic freedom are within Group III.

Following the results, the authors compiled their ranking list of countries based on new findings from the previous calculation that highlight the importance of each component for growth. They also found that their construction of an aggregate index based on the importance of each aspect of freedom was not highly correlated with the rank traditionally constructed by Fraser led by Gwartney et al. (1996). They launched a new bivariate regression and found that the newly constructed index showed a significant link to economic growth.

Supporting the arguments and criticisms made by Heckelman \& Stroup (2000) regarding the Fraser Institute index aggregation (Gwartney et al. 1996), but also challenging the new methodology used by the mentioned authors in the process of constructing their own index, Sturm, Leertouwer \& Haan (2002) make some efforts to advance indicators of economic 
Ivana Brkić

freedom of certain countries. Using Principal component analysis, the authors conduct their own index aggregation. They find that their index is significantly correlated with the index of Gwartney et al. (1996) and in a very weak relationship with the constructed index of Heckelman \& Stroup (2000). Another objection to Heckelman \& Stroup (2000) was made concerning omitting the control variables in the model when examining the impact of the newly constructed index of economic freedom on economic growth, which leads to the sensitivity of results in relation to the selection of countries. Therefore, Sturm et al. (2002) carry out the analysis established by Levine \& Renelt (1992) for robustness testing. They conclude that only the index constructed by Heckelman \& Stroup (2000) has a weak positive relationship with economic growth, whereas the freedom expressed by the Fraser Institute index (Gwartney et al., 1996), as well as the indicator made by the authors themselves in the paper in question, does not show robustness in the relation "level of economic freedom - economic growth".

Carlsson \& Lundström (2002) also point out that a comprehensive index of economic freedoms is not a sufficiently precise guideline as it cannot signal to economic policy makers which segment needs to be improved in order to stimulate economic growth. By decomposing the index given by the Fraser Institute in its report (Gwartney, Lawson \& Samida, 2000) and applying the so-called Extreme Bound Analysis (EBA) to determine the robustness of the linkages of the impact of individual aspects of economic freedom on growth, they obtain diverse results. Although they found that overall economic freedom has a positive (and robust) impact on growth, they caution that some of its components have no significant link ("monetary policy and price stability"), but also that some have a negative impact on growth. Thus, an increase in the "size of government" by one unit reduces economic growth by $0.5 \%$ and "freedom of trade with foreigners" by $0.48 \%$. The previous findings that larger government stimulates growth, as well as that greater international exchange has a negative impact, are contrary to the results of earlier studies. While "economic structure and market availability" do not have a robust link to growth, "freedom to use alternative currencies", "freedom to trade in the capital market" and "legal structure and protection of property rights" do not only have a positive but also (more or less) a robust link to growth. 
Ivana Brkić

Focusing on corruption in their analysis of the impact of particular categories of economic freedom, us Swaleheen \& Stansel (2007) concluded that in countries with a low level of economic freedom, where individuals face limited choices, corruption reduces economic growth. Contradictory and contrary to well-founded views in the professional literature, their results show that in countries with a higher degree of economic freedom, reducing corruption will slow economic growth. The authors interpret such findings by the view recognized in scientific circles (Osterfeld, 1992) that in countries with a high level of economic freedom, where there is a minimum of necessary restrictions, bribery of employees not to do their jobs leads to greater economic activity and economic growth. Yet, in countries with a high level of corruption, the growth of economic freedom, increases economic growth, as argued by us Swaleheen \& Stansel (2007).

Cebula (2011; Cebula, Clark \& Mixon, 2013; Cebula \& Clark 2014; Cebula \& Mixon, 2012, 2014) conducted several studies independently or in collaboration with other authors in which he studied the relationship between economic freedom and the state of the economies of 30 member countries of the Organizations for Economic Co-operation and Development (OECD), mainly covering the period 2003-2007. Thus, in his first works on this topic, the author Cebula (2011) conducted a panel analysis and came to the conclusion that economic freedom has a positive effect on the level of GDP per capita. This was particularly true of aspects of monetary and fiscal freedom, freedom of business, investment, labor, freedom from corruption and protection of property rights. The author obtained these results using the Heritage Foundation Index, but confirmed the robustness of the conclusion about the positive impact of economic freedom on the economy level by using the Fraser Institute index (Gwartney and Lawson, 2008).

Cebula, Clark \& Mixon (2013) later conducted a study within 30 OECD member countries from 2003 to 2006 in order to investigate whether a higher level of economic freedom encourages a higher level of economic activity (ceteris paribus) and therefore a higher level of real GDP per capita. The authors then found that business freedom, freedom from corruption, investment freedom, monetary freedom, government spending, trade freedom and protection of property rights are a growing function of real per capita income. Their calculations show that one-unit growth of the said categories of economic freedom increases real GDP per capita by 
Ivana Brkić

$\$ 165, \$ 142, \$ 297, \$ 717, \$ 170, \$ 377$ and $\$ 317$, respectively. Therefore, the greatest impact on GDP per capita is brought in the following order: by monetary freedom, trade freedom, protection of property rights and investment freedom. On the other hand, labor, financial and fiscal freedom do not show statistical significance, while the first two have a negative coefficient. Cebula (2013) proves that the same elements of economic freedom have a positive effect on GDP levels. Compared to his previous studies, in this paper, some aspects show different results, but most categories confirmed the nature of their relationship with the level of real income.

Modifying the Heritage Foundation Economic Freedom Index by omitting Fiscal Freedom and Business Freedom, Cebula \& Clark (2014) again sought to check the impact of the liberalization of economic activities on the attained level and size of GDP of OECD member countries. They obtained the expected positive impact, and robustness was checked by omitting the Group of Eight leading industrial countries (G8) from the sample. They also noted that higher levels of regulatory policy quality and lower tax burden have a positive impact on GDP per capita

In their next study, Cebula \& Mixon (2014) examined the impact of economic freedom (this time) on GDP growth, emphasizing the direct and indirect impact that such a relationship can have on the energy sector and infrastructure development. This time, too, the authors come to positive results, whose robustness was confirmed by different model specifications but also by applying the Fraser Institute's alternative Index of Economic Freedom.

An empirical study by Cebula \& Mixon (2012) examined the impact of fiscal freedom and freedom from excessive public spending on a sample of OECD member countries from 2004 to 2007. The authors concluded that lower levels of all taxes, i.e. greater fiscal freedom and lower levels of public spending, lead to economic growth. The robustness of the results was tested by a different model specification that included both trade freedom and the aspect of economic freedom relating to the protection of property rights. Both of these categories showed a positive impact on economic growth, while fiscal freedom and freedom from (too) much public spending confirmed and strengthened their influence. 
Ivana Brkić

The authors Akin, Aytun \&Aktakas (2014) aimed to investigate the impact of economic freedom on economic growth within countries with varying levels of income. They conducted a panel analysis on a sample of 94 countries, categorizing high-income countries which are members of the Organization for Economic Co-operation and Development and those which are not, into upper-middle and lower-middle-income countries as well as low-income countries. They concluded that in all countries, regardless of income level, the level of economic freedom is in a positive, statistically significant relation to economic growth. An additional aspect of this finding is also the conclusion that the most significant contribution to the growth of economic freedom comes from lower middle income countries (Bolivia, Republic of Congo, Egypt, India, Pakistan, Indonesia, Paraguay, Sri Lanka, Syria, Ukraine, Zambia, El Salvador, Guatemala, Honduras, Senegal). Thus, the growth of economic freedom by $1 \%$ leads to economic growth of $0.482 \%$ in OECD member countries, $0.422 \%$ in high-income non-member countries, $0.266 \%$ in countries with upper-middle income level and in lower-middle income countries and low-income countries by $0.555 \%$ and $0.331 \%$, respectively.

In the second phase of the analysis, the authors set out to investigate the impact of the economic freedom components expressed by the Fraser Institute's Economic Freedom Index (Gwartney, Lawson\& Hall, 2012) and examine their individual contribution to growth in countries with varying levels of income. They obtained different answers. Thus, (1) government size has a positive and statistically significant effect on growth in the middle-income group of countries. They note that (2) the efficiency of the courts and the protection of property rights have a positive impact on growth in OECD non-member countries and at the same time achieve high levels of income as well as in middle (upper and lower) income countries. As the level of income decreases, so does the significance of this factor. Strong currency, price stability, ability to own foreign currency (3) in the context of economic freedom are significant drivers of growth, not only in OECD countries but also in the lower-middle income group. While freedom in international trade (4) in OECD countries has a negative effect on the economy, with declining revenues, this aspect becomes positive. Regulations (5), the last pillar of economic freedom, which implies the responsibility of the state and its involvement in the process of promoting freedom, proved to be significant and positive in OECD countries, both with higher and lower levels of income. 
Ivana Brkić

Levente (2015) focused his attention on examining one important aspect of economic freedom: the size of government spending. Many papers explored the link between government size and economic growth and found both a positive and a negative link. Due to the very fact that it is difficult to determine the true sign that characterizes this relationship, Levente (2015) tried to define the variables that construct such a relationship. The author found, in accordance with previous results in the scientific literature, that there is a form of the reversed Latin letter " $u$ " between public spending and economic growth. Excessive and too low public spending do not encourage economic growth. Unlike Tanzi (2005), who advocates $30 \%$ of public spending relative to GDP, Levente (2015) argues that there is no single optimum of public spending, but it depends on the level of development of the country, which depends on economic freedom. Thus, according to his calculations, developed countries have a significantly higher level of public spending that maximizes economic growth compared to underdeveloped countries. Subsequently, the growth of public spending will slow economic growth, as claimed by the author. The optimal relationship between public spending and economic growth was written about by Armey (1995), constructing the so-called Armey curve, coined by Vedder \& Gallaway (1998).

Levente (2015) divided countries into 64 free and 57 less free countries according to the Fraser Institute criterion. Free economies had five times higher GDP in 1995 than less free ones and since then their growth rate was far faster than the in the other ones. The authors conclude that less free countries have little chance of catching up with the freer ones because their institutional system does not allow for faster growth. Freer countries have higher public expenditures because they can afford it. Levente (2015) analyzed the structure of expenditures and found that the money earmarked for health is higher but the costs for education and defense are lower in developed than in less developed countries. The author noted the same when he divided the countries into groups with good and bad legal system and protection of property rights. Well-regulated countries have a high GDP and a high growth rate. This also allows them to distribute their revenues, which means higher public expenditures. As regards corruption control, the conclusions are even more significant: less corrupt countries achieved nine times GDP in 1995, while the growth rate for both groups of countries, more and less corrupt, is about the same. 
There is no consensus among scholars on the question of prioritizing the examination of the impact of index components or their aggregate level on economic growth. There are numerous views that the aggregate index of economic freedom is not really a relevant indicator as it does not give macroeconomic policy makers a clear signal of what should be applied specifically in order to promote growth (Heckelman \& Stroup, 2000). Nevertheless, the role and contribution of the overall index of economic freedom must be acknowledged. Lawson (2006) on this topic draws an analogy in weighing the significance of the total index as opposed to the significance of its parts, looking for the most important ingredient in a cherry cake, pointing out that all elements are just as important if you want to have a delicious cake, which can also be passed on to the index of economic freedom. De Haan \& Sturm (2006), on the other hand, remind that many scholars found that some elements have a low correlation both with other components and with the overall index, and therefore conclude that not all dimensions are equally significant or responsible for growth. At the same time, they propose the use of factor analysis for grouping index elements into pillars (groups) since they believe that the grouping of individual subcategories of the Fraser Institute index was done arbitrarily at that time.

The fact is that the measure of economic freedom is too rough and that there are still no satisfactory econometric calculations that could absorb all the problems that arise in this process.

\subsubsection{EXAMINING THE RELATIONSHIP BETWEEN LEVEL VS. CHANGE IN THE LEVEL OF ECONOMIC FREEDOM AND ECONOMIC GROWTH}

There were two trends in scientific circles that stood out in terms of determining the relation "economic freedom - growth". While most studies put economic growth rate and level of economic freedom in regression, some scholars criticized such a methodological decision and suggested that changing economic freedom (and not its level) is robustly related to growth (De Haan \& Siermann, 1998; De Haan \& Sturm, 2000, 2001; Pitlik, 2002; Sturm, Leertouwer \& Haan, 2002; Doucouliagos \& Ulubasoglu, 2006; Wu, 2011). 
Ivana Brkić

De Haan \& Sturm (2000) were among the first in this context to examine the relationship between economic freedom and economic growth. In addition to this contribution, the authors also compared two most significant indicators of economic freedom: of the Fraser Institute and of the Heritage Foundation, concluding that, with some differences in individual areas, the ranking of countries based on economic freedom category is fairly uniform. Later, they followed developments in the level of economic freedom and economic growth in 80 countries. They used the level of economic freedom from 1975 and its change from 1975 to 1990 as an independent variable. They came to the conclusion that the level of economic freedom (from 1975) was not related to economic growth, but that the change of economic freedom was strongly linked to growth. With this finding, they pointed to the conclusion that the growth of economic freedom encourages economic growth for aspiring countries that have not yet achieved a steady growth trend. On the other hand, in countries that have a stable (high) level of economic growth, economic freedom does not affect their economic progress, as summed up by De Haan \& Sturm (2000).

In their subsequent work, Sturm \& De Haan (2001) continued to address the issue of examining robustness in the relationship between growth and economic freedom. As they found in previous work that even by specifying the growth model in terms of including control variables (the initial GDP level, average investment rate expressed as \% of GDP, high school enrollment in 1975as well as average population growth, average level of public spending, expressed as \% of GDP, average inflation rate and average export-import ratio relative to GDP), the link between the level of economic freedom and growth does not become robust, this time they used the Least Median of Squares - LMS regression model to strengthen or refute their evidence. Again, the authors concluded that a change of economic freedom is strongly linked to growth, which cannot be claimed for its level.

Like many authors before him, Pitlik (2002) studied the impact of economic liberalization on economic growth, assuming that such an impact is positive. Pitlik (2002) focused on examining the long-term impact of economic liberalization on economic progress. He examined the effects of a stable as opposed to indecisive economic liberalization policy, which not only negatively contributes to economic growth, but also adversely affects the credibility of 
Ivana Brkić

the government, the attractiveness of foreign direct investment, etc. In a sample of 80 countries, covering the period between 1975 and 1995, the author applied the Ordinary Least Squares (OLS) model to investigate the long-term impact of institutional changes on economic growth. He proved that the movement of the economic freedom index up one notch contributes to annual GDP growth by $0.9 \%$, while the volatility of a given policy leads to an economic decline by 2.3\%. The analysis proved that instability in the path of liberalization leads to a decline in economic activity, even in situations where countries experience growth in economic freedom in the long run. This way he indicated that the reform strategy needs to be implemented gradually and consistently, which can lead to greater long-term economic growth. By adding control variables and applying EBA, Pitlik (2002) proved robustness of results, confirming the thesis that regardless of model specification, change of economic freedom is positively and statistically significantly related to economic growth.

To assess the effect of economic freedom in the context of growth regression, Cole (2003) applied two completely different approaches to test the robustness of the relation freedom-growth. The results he obtained can be contrasted with standard growth models, which predict slower growth in countries with higher levels of development, due to reduced return on capital. The truth is that, as the neoclassical model predicts, higher-income countries will have an initial slower growth, while lower-income countries will initially have a more intense growth. The assumptions he started with in both models to satisfy the convergence effects are: (1) if two countries are at the same level of economic freedom, the country with a higher initial income will tend to grow more slowly under the influence of convergence effect and (2) if two countries start with the same income level, the country with more pronounced economic freedom will tend to grow faster. The author sets up a neoclassical-model based regression which assumes the inclusion of an economic freedom index in a growth regression based on an extended model set up by Solow (Mankiw et al., 1992; Knight, Loayza \& Villanueva, 1993). This model includes initial income (from 1980), investment as a percentage of GDP (average for the period 19801999), population increase (average fertility rate for the period 1980-99) and average change in years of education in the period 1980-1995 as a measure of human capital. The economic freedom included in the model is derived from the average value of the economic freedom index provided by the Fraser Institute for 1980, 1985, 1990, and 1995 for each country. Based on this 
Ivana Brkić

model, the variables presented account for $69.5 \%$ of the variable, and the coefficient for the freedom index is positive and significant. A change of the index of economic freedom, which has a significant and positive impact on growth and increases the explanatory power of the variable to $74.1 \%$ was added in the next regression. The results from this model further indicate that any given level of investment will have a greater impact on growth in countries with greater degrees of economic freedom.

The second model includes the economic freedom index in the model proposed by Gallup, Sachs \& Mellinger (1999). Such a model studies the relationship between the geographical position of countries and their economic development and is based on the following empirical observations: (1) countries in the tropics are predisposed to be poor, while countries in temperate climates tend to be richer (Sachs, 2000) and (2) countries with maritime traffic tend to be richer than continental countries. Based on all of the above, in addition to the initial income (due to the convergence effect), the given model includes the location of the country in relation to the tropics, the proportion of the population living in a country with 100 kilometers of sea coast, and the distance from one of the three key centers of the world economy (New York, Rotterdam, Tokyo). Adding the level of the freedom index as well as its change over a given period increases the explanatory power of the variable (GDP per capita growth rate) from $23.9 \%$ to $54.3 \%$. It is important to note that the latter growth model estimates the impact of economic freedom on economic growth even stronger than the neoclassical model.

The aim of this study was to compare different theories of economic growth, as well as to assess the impact of economic freedom on economic growth in alternative theoretical frameworks. A significant finding is that both the level and growth of economic freedom, expressed by the Fraser Institute's index of economic freedom, are highly correlated with per capita GDP growth, regardless of the set theoretical framework for economic growth.

Giving a very detailed tabular overview of scientific papers dealing with discovering the link between economic freedom and economic growth, De Haan, Lundström \&Sturm (2006) conclude that most researchers found a positive correlation between these variables, although they dispute the specific methodology used in them. The biggest criticism seems to be directed at the use of both level and change in the level of index in the same regression, pointing to statistical issues (endogeneity, reversed causality, multicollinearity) and they suggest including 
Ivana Brkić

exclusively a change in the level of economic freedom in the regression models. In response to the above remark, Lawson (2006) points out that the application of both forms of economic freedom (both level and growth) is more adequate to conduct research. He supports such an attitude by comparing economically developed Hong Kong (which is always at the top of the world list of economic freedom and has no room for further growth) and e.g. Nicaragua, which is improving its position year after year but still has a relatively low ranking (and low level of economic growth). By omitting the level of economic freedom from the specification of the econometric model, Lawson (2006) states, Hong Kong would be of no interest as a country with a pronounced link between economic freedom and growth. Only by using both forms of freedom, Lawson (2006) concludes, will we be able to see how economic freedom affects economic growth in the case of developed and less developed countries. In the ensuing debate (De Haan \& Sturm, 2006; Cole \& Lawson, 2007; De Haan \& Sturm, 2007), there was no scientific consensus on this and other topics regarding the choice of method or form of economic freedom (in terms of level, change, aggregate index vs. index components), therefore it is the task of further and other research to provide new evidence and arguments.

There is (eternal) debate in society as to whether competition and liberalization are always good. There are views that intelligently managed and implemented state control can lead to positive economic results. The problem with any empirical study is that an economic policy variable cannot be quantified and thus included in the econometric model ( $\mathrm{Wu}, 2011)$. In the context of intellectual nonuniformity on the unique path of economic growth, China is certainly a specific case. This country recorded an economic growth of $10 \%$ per year in the previous decade, but also a rather low rating on the economic freedom index scale, with no upward trend. According to $\mathrm{Wu}$ (2011), a relatively underdeveloped legal and financial system in China, as well as high level of corruption, certainly do not favour economic freedom. However, limited freedom in the financial market and cross-border capital in China, this time protected China from the global economic crisis that has been recorded in the past decade. In order to examine in his own way the impact of economic freedom on growth, Wu (2011) conducted an analysis of the relationship between economic growth and the level, but also the change, of economic freedom. The results suggest that the level of economic freedom is not statistically significant, while the change of economic freedoms shows a positive and statistically significant relationship with 
Ivana Brkić

economic growth. However, the author distances himself from the unequivocal conclusion, pointing out that the causality of the given relationship has not been examined (whether economic growth can lead to the improvement of economic freedom, the so-called reverse causality), and that both variables are actually influenced by a third factor (endogeneity).

Below are a detailed tabular overview of the studies described above and the summary of their conclusions regarding the relationship between (change of) economic freedom and economic level and/or growth (Table 7). 
Table 7. Tabular overview of conducted research on the relationship between (change of) economic freedom and economic level and/or growth

\begin{tabular}{|c|c|c|c|c|c|c|}
\hline AUTHOR(S) & SAMPLE & $\begin{array}{l}\text { RESEARCH } \\
\text { PERIOD }\end{array}$ & METHOD & $\begin{array}{l}\text { DEPENDENT } \\
\text { VARIABLE }\end{array}$ & INDEPENDENT VARIABLE & EFFECTS \\
\hline \multirow[b]{2}{*}{ Islam (1996) } & \multirow{2}{*}{$\begin{array}{l}94 \text { countries: } \\
28 \text { low-income } \\
43 \text { middle-income } \\
23 \text { high-income }\end{array}$} & \multirow[b]{2}{*}{$1980-1992$} & \multirow{2}{*}{$\begin{array}{l}\text { Ordinary least squares } \\
\text { Cross- section analysis }\end{array}$} & $\begin{array}{l}\text { GNP per capita } \\
\text { (1992) }\end{array}$ & \multirow{2}{*}{$\begin{array}{l}\text { IEF of the Fraser Institute } \\
\text { (Easton \&Walker, 1992) }\end{array}$} & \multirow[b]{2}{*}{ Positive. } \\
\hline & & & & $\begin{array}{l}\text { Average GNP } \\
\text { per capita } \\
\text { growth rate }\end{array}$ & & \\
\hline \multicolumn{7}{|c|}{$\begin{array}{l}\text { The decline in economic freedom leads to a fall in per capita income in low-income countries and in all sample countries. } \\
\text { The decline in economic freedom leads to a slowdown in economic growth in high-income countries, as well as in all the sample countries. } \\
\text { Growth in per capita income leads increase in economic freedom in all countries and in low-income countries. }\end{array}$} \\
\hline Ayal\& Karras (1998) & 58countries & $1975-1990$ & Multivariate regression & $\begin{array}{l}\text { Average GDP } \\
\text { per capita } \\
\text { growth rate }\end{array}$ & $\begin{array}{l}13 \text { components of IEF of the } \\
\text { Fraser Institute } \\
\text { (Gwartney et al., 1996) } \\
\text { - Initial GDP per capita } \\
\text { - Investment (\% of GDP) } \\
\text { - Population growth rate }\end{array}$ & Positive. \\
\hline \multicolumn{7}{|c|}{ All thirteen components of economic freedom show a positive correlation coefficient with growth, but six of them are statistically significant. } \\
\hline $\begin{array}{l}\text { Heckelman\&Stroup } \\
\text { (2000) }\end{array}$ & 49 countries & $\begin{array}{l}\text { Growth: } 1980- \\
1990 \text { IEF: from } \\
1980\end{array}$ & $\begin{array}{l}\text { Bivariate regression } \\
\text { Multivariate regression } \\
\text { Ordinary least squares }\end{array}$ & $\begin{array}{l}\text { Average GDP } \\
\text { per capita } \\
\text { growth rate }\end{array}$ & $\begin{array}{l}\text { IEF of the Fraser Institute } \\
\text { (Gwartney et al., 1996) }\end{array}$ & Positive. \\
\hline \multicolumn{7}{|c|}{$\begin{array}{l}\text { The overall level of economic freedom is not related to growth but some of its elements are in statistically significant relation to economic growth: } \\
\text { Marginal tax rate, negative relationship; Transfers and subsidies (\% of GDP), positive relationship; Difference between the official and black market exchange rates, positive } \\
\text { relationship. The new index that the authors construct based on the importance of each component for growth is related to growth. }\end{array}$} \\
\hline $\begin{array}{c}\text { Carlsson \& } \\
\text { Lundström (2002) }\end{array}$ & 74countries & $\begin{array}{l}\text { Growth: } 1975- \\
\quad 1995 \\
\text { IEF: } 1970-1990\end{array}$ & EBA & $\begin{array}{l}\text { Average GDP } \\
\text { per capita } \\
\text { growth rate }\end{array}$ & $\begin{array}{l}\text { IEF of the Fraser Institute } \\
\text { (Gwartney et al., 2000) } \\
\text { - Initial GDP per capita } \\
\text { - Investment (\% of GDP) }\end{array}$ & Positive. \\
\hline \multicolumn{7}{|c|}{$\begin{array}{l}\text { The overall index of economic freedom - positive, robust. Government size - negative, robust. Economy structure and market use - positive, not robust. Monetary policy and price } \\
\text { stability - insignificant, not robust. Freedom to use alternative currencies - positive, almost robust. Legal structure and protection of property rights - positive, robust. International } \\
\text { trade - negative, almost robust. Trade freedom in the capital market - positive, almost robust. }\end{array}$} \\
\hline $\begin{array}{l}\text { Akin, Aytun \& } \\
\text { Aktakas (2014) }\end{array}$ & 94countries & $2000-2010$ & Panel analysis & GDP & $\begin{array}{l}\quad \begin{array}{l}\text { IEF of the Fraser Institute } \\
\text { (Gwartney et al., 2012) }\end{array} \\
\text { Gross national formations } \\
\text { Human capital index } \\
\text { Population }\end{array}$ & Positive. \\
\hline
\end{tabular}




\begin{tabular}{|c|c|c|c|c|c|c|}
\hline AUTHOR(S) & SAMPLE & $\begin{array}{l}\text { RESEARCH } \\
\text { PERIOD }\end{array}$ & METHOD & $\begin{array}{l}\text { DEPENDENT } \\
\text { VARIABLE }\end{array}$ & INDEPENDENT VARIABLE & EFFECTS \\
\hline \multicolumn{7}{|c|}{$\begin{array}{l}\text { countries. } \\
\text { 2) Judicial system and protection of property rights - the efficiency of the courts and the protection of property rights have a positive impact on growth in non-OECD countries and } \\
\text { have a high level of income, as well as in middle (upper and lower) income countries. The decrease in income increases the significance of this factor. } \\
\text { 3) Money stability - a significant driver of growth, not only in OECD countries, but also in the group of lower middle income countries. } \\
\text { 4) International trade - in OECD countries it has a negative effect on the economy, with the decrease in income, this aspect becomes positive. } \\
\text { 5) Regulations - a significant and positive coefficient in OECD countries, with both higher and lower levels of income. }\end{array}$} \\
\hline Cebula (2011) & $\begin{array}{l}30 \\
\text { OECD countries }\end{array}$ & $2003-2007$ & Panel analysis & GDP per capita & $\begin{array}{l}\text { IEF of the Heritage Foundation } \\
\text { IEF of the Fraser Institute } \\
\text { Political Stability Index } \\
\text { Long-term nominal interest rate }\end{array}$ & Positive. \\
\hline \multicolumn{7}{|c|}{$\begin{array}{l}\text { Monetary and fiscal freedom, business, investment, labor freedom, freedom from corruption and protection of property rights have a positive and statistically significant impact on } \\
\text { the level of GDP per capita. Political stability has a positive and statistically significant impact on GDP per capita. High nominal interest rates have a negative and statistically } \\
\text { significant impact on GDP per capita. }\end{array}$} \\
\hline $\begin{array}{l}\text { Cebula \& Mixon } \\
\qquad(2012)\end{array}$ & $\begin{array}{l}30 \\
\text { OECDcountries }\end{array}$ & $2004-2007$ & Panel analysis & $\begin{array}{l}\text { GDP growth } \\
\text { per capita }\end{array}$ & $\begin{array}{l}\text { IEF of the Heritage Foundation: } \\
\text { Fiscal freedom } \\
\text { Government spending } \\
\text { Protection of property rights } \\
\text { Trade freedom } \\
\text {----- } \% \text { of GDP) } \\
\text { Net exports } \\
\text { Budget deficits (\% of GDP) } \\
\text { Long-term nominal interest rate } \\
\text { Binary variable for G8 countries }\end{array}$ & Positive. \\
\hline \multicolumn{7}{|c|}{ Fiscal freedom, reduced public spending, protected property rights and free trade have a positive and statistically significant impact on GDP growth per capita. } \\
\hline $\begin{array}{l}\text { Cebula, Clark \& } \\
\text { Mixon (2013) }\end{array}$ & $\begin{array}{c}30 \\
\text { OECDcountries }\end{array}$ & $2003-2006$ & $\begin{array}{l}\text { Panel analysis } \\
\text { (fixed effects model) }\end{array}$ & GDP per capita & $\begin{array}{l}\text { IEF of the Heritage Foundation } \\
\text { - \% unemployment } \\
\text { - long-term interest rate (expost) }\end{array}$ & Positive. \\
\hline \multicolumn{7}{|c|}{$\begin{array}{l}\text { Positive, statistically significant coefficient: business freedom, freedom from corruption, investment freedom, monetary freedom, government spending, trade freedom, protection } \\
\text { of property rights. Not statistically significant: fiscal freedom, labor freedom (-), financial freedom (-). }\end{array}$} \\
\hline Cebula (2013) & $\begin{array}{l}30 \\
\text { OECDcountries }\end{array}$ & $2003-2006$ & Panel analysis & GDP per capita & IEFof the Heritage Foundation & Positive. \\
\hline \multicolumn{7}{|c|}{$\begin{array}{l}\text { Business freedom, monetary freedom, freedom from corruption, investment freedom, public spending, trade freedom and protection of property rights all have a positive and } \\
\text { statistically significant impact on GDP level. Fiscal freedom, financial freedom and labor freedom do not have a statistically significant impact. }\end{array}$} \\
\hline $\begin{array}{l}\text { Cebula \& Mixon } \\
\qquad(2014)\end{array}$ & 29 countries & $2004-2007$ & Panel analysis & $\begin{array}{l}\text { Annual GDP } \\
\text { per capita } \\
\text { growth rate }\end{array}$ & $\begin{array}{l}\begin{array}{l}\text { Modified IEF of the Heritage } \\
\text { Foundation without business } \\
\text { freedom }\end{array} \\
\text { IEF of the Fraser Institute } \\
\end{array}$ & Positive. \\
\hline
\end{tabular}


The relationship between economic freedom and economic growth in EU countries Ivana Brkić

\begin{tabular}{|c|c|c|c|c|c|c|}
\hline AUTHOR(S) & SAMPLE & $\begin{array}{l}\text { RESEARCH } \\
\text { PERIOD }\end{array}$ & METHOD & $\begin{array}{l}\text { DEPENDENT } \\
\text { VARIABLE }\end{array}$ & INDEPENDENT VARIABLE & EFFECTS \\
\hline & & & & & $\begin{array}{l}\text { Regulatory Quality Index } \\
\text { Unemployment }(\%) \\
\text { Long-term real interest rate (\%) } \\
\text { Binary variable for G8 countries }\end{array}$ & \\
\hline \multicolumn{7}{|c|}{$\begin{array}{l}\text { Economic freedom has a positive and statistically significant impact on economic growth. Confirmed robustness of results using different model specifications. Using the Fraser } \\
\text { Institute alternative index, the robustness of the results is proven. }\end{array}$} \\
\hline $\begin{array}{c}\text { Cebula \&Clark } \\
\text { (2014) }\end{array}$ & $\begin{array}{c}30 \\
\text { OECDcountries }\end{array}$ & $2003-2007$ & $\begin{array}{c}\text { Panel analysis } \\
\text { (fixed effects model) }\end{array}$ & GDP per capita & $\begin{array}{l}\text { IEF of the Heritage } \\
\text { Foundation(without fiscal } \\
\text { freedom and business freedom) } \\
\text { Regulatory Policy Index } \\
\text { All taxes (\% of GDP) } \\
\text { Political Stability Index } \\
\text { Unemployment (\%) } \\
\text { Long-term real interest rate (\%) } \\
\text { Budget deficits }\end{array}$ & Positive. \\
\hline
\end{tabular}

Source: Author. 


\subsubsection{EXAMINING THE CAUSALITY IN THE RELATIONSHIP BETWEEN ECONOMIC FREEDOM AND ECONOMIC GROWTH}

A large number of empirical studies have proven a positive relationship between the various measures of economic freedom and the rate of economic growth worldwide. Starting from the founders of modern economics (Smith, 2010) until recent work, scientists have emphasized the importance of the role of institutions in achieving economic results. Dawson (1998) and Gwartney, Lawson \& Holcombe (1999) first identified the (positive) link between economic freedom and economic growth, while Ayal \& Karras (1998) and Carlsson \& Lundström (2002) later studied components of economic freedom that more or less influence growth. The aforementioned studies indicate a correlation between different measures of economic freedom and growth, but do not address the causality of these categories. In other words, up to some point in recent history, it has not been studied whether economic freedom is the cause of economic growth, or is a more developed society, supported by government, becoming economically freer. Certainly, there is a possibility that their relationship was influenced by some third factor.

Although earlier studies focused on exogenous factors in discovering the causes of economic growth, more recent studies suggest the importance of endogenous variables for growth. Although it is difficult to define the factors that influence economic growth, it can be assumed that a higher level of economic (and political) freedom encourages growth. It can also be assumed that economic progress influences the progress of economic and political freedom.

Although most research supports the thesis that political freedom contributes to growth, there are conflicting opinions which propagate that political freedom has a negative impact on growth, especially in countries with lower levels of economic and political development. Therefore, authors Farr, Lord \& Wolfenbarger (1998) sought to establish a causal link between economic, political freedom, and economic status of countries of different levels of development. In a group of 20 industrial and 78 non-industrial countries, within the available data on the level of economic freedom of the Fraser Institute (1975, 1980, 1985, 1990), as well as based on summarized indicators of political rights and civil liberty of Freedom House, Farr et al. (1998) were among the first to conduct a test of 
causality in Granger's sense - whether one occurrence precedes the other (Granger, 1969). The results for both groups of countries show that economic freedom (in the past) is significantly related to GDP per capita (in the present), while political freedom is not. Reversing the relations shows that the level of GDP per capita in the past is significantly linked to both economic and political freedom in the present, for both groups of countries. From the point of view of the significance of the impact, the higher prediction strength is recorded by gross domestic product over economic freedom (1\%), while the "preceding" power of freedom in opposition to gross domestic product is expressed by statistical significance of 5\%. Interestingly, political and economic freedom do not have a statistically significant relationship, in any direction (economic freedom does not cause political, or vice versa). Following these findings, it can be concluded that the level of economic development connects the two freedoms in the following way: greater economic freedom causes higher GDP (in Granger's sense), which in turn causes greater political freedom. In other words, economic freedom indirectly causes political freedom, affecting economic growth. This bears out the thought written by Milton Friedman in his book Capitalism and Freedom (Friedman, 1962), where he states: "The relation between political and economic freedom is complex and by no means unilateral."

Heckelman (2000) analyzes the causality between growth and economic freedom whereby for the dependent variable (unlike Farr et al. (1998)) he chooses average GDP growth rate. Following the methodology used by Heckelman \& Stroup (2000), the author examines the relationships with economic growth of not only the comprehensive index but also of its individual components. Another difference and advantage of this author's research is the application of the Heritage Foundation index, which, as the author states, is based on measuring policies rather than macroeconomic outcomes as opposed to the Fraser Institute index. To prevent eliminating the effect of business cycles due to the implementation of annual data published by the Heritage Foundation on the state of economic freedom, Heckelman (2000) uses lag length of up to three years between indicators of economic freedom and growth. He concluded that economic freedom leads to growth by making a gap of one, two or three years. This is especially true of the element of Monetary Policy (which estimates the average inflation rate over the last 10 years). As this research was conducted over a period of just four years, the message to policy makers is that the short-term effects of freedom can have an impact on growth, especially if inflation is kept low. The contribution to (short-term) economic growth is also made by segments related to Capital flows and Foreign 
Ivana Brkić

investment (counterpart of today's Investment freedom), Price and wage control (equivalent to Monetary freedom related to price control and Labor freedom), Property rights and Regulations (Business freedom), which are manifested after two or three years. Less robustness was found in the analysis of Granger causality whereby the Banking and Black market segments cause growth only after three years. The results showed no robustness even when it comes to causing (in Granger's sense) economic freedom by growth, where only one segment (State interventions) is a consequence of growth, which is manifested only after two years.

Studies published by Farr et al. (1998) and Heckelman (2000) previously discussed dealt with the relationship between economic freedom and economic growth, but the conclusions remain unclear. Thus, Farr et al. (1998) examined the causality of economic freedom and standard of living, expressed by a level of GDP, instead of the rate of GDP growth, which turned out to be a poor choice. Likewise, the above authors did not examine individual aspects of economic freedom and their impact on economic growth. Therefore, such research was done by Heckelman (2000) who found that the level of economic freedom, as well as many of its components, causes economic growth. Likewise, economic growth affects some of the aspects of the overall index of economic freedoms compiled by the Heritage Foundation. The lack of analysis conducted by Heckelman (2000) is a small number of years of observation, as is the inability to completely eliminate the effects caused by business cycles due to the use of annual data. Both previous analyses did not take into account the third variable that could have influenced the construction of the freedom - growth relationship. In all studies where the focus is on economic freedom and economic growth, the question of sensitivity of results to sample changes (which countries are included in the socalled cross-country analysis and which are not) as well as to changes in the variables included in the regression model (Levine \& Renelt, 1992)always remain open. Another methodological issue in calculating the link between economic freedom and economic growth is the use of average values. Many authors (e.g., Ayal \& Karras, 1998; Carlsson \&Lundström, 2002) use the average level of economic freedom to explain growth over a given period. By comparing these means, it is difficult to distinguish between correlation and causality. Also, the growth of freedom in one period may cause the growth of freedom in another period, which obscures the selection of the indicator presented in such a way. For this reason, each author individually, makes a specification, explains why he chose the countries (transitional, members of a certain organization, etc.) and just for a certain period of time 
Ivana Brkić

(absence of consequences of the financial crisis of 2008, oil crisis in the mid and late $70 \mathrm{~s}$ after the period of the wars), because all these aspects can distort the picture of the "freedom growth" relationship due to the unfulfilled ceteris paribus conditions.

Following a long-run series of data from 1970 to 2000, Dawson (2003) concluded that the overall level of economic freedom, as measured by the Gwartney \& Lawson (2001) index, causes growth in Granger's sense of causality. This result strengthens the link that had been proven many times in the literature, suggesting that economic freedom actually causes economic growth. As for the individual components of freedom, causality was established, but their direction is different. Thus, "market use" and "property rights" cause growth, while economic growth is what causes "government size". This conclusion on higher consumption by a developed country was confirmed by Levente (2015) later in his work. Although earlier works found a correlation between "international trade" and economic growth (eg. Carlsson \& Lundström, 2002; Ayal \& Karras, 1998), Dawson (2003) does not find Granger's causality in a given relationship (in either direction). Freedom in terms of "monetary policy and price stability" is endogenously determined by growth, while "use of alternative currencies" and "international finance" are sensitive to specification, which makes it difficult to assess the direction of causality. Dawson (2003) also observed how changes in the level of economic freedom affect growth, and noted the endogenous relationship between changes in freedom and growth, while changes in individual aspects of freedom do not cause growth. Moreover, changes in some categories, such as "market size" and "international finance", are caused by growth.

Dawson (2003) came to very significant conclusions regarding the long-term effects in the relationship between freedom and growth. Specifically, economic freedom was found to cause growth in the short run, while in the long run, this relation does not show any significance. This lack of significance was also noted for certain categories of economic freedom. These results on long-term effects are certainly contrary to previous scientific findings on the importance of institutions for economic growth. The author explains his research by the fact that it covers only the aspect of economic freedom and encourages the development of indicators of economic freedom.

Dawson (2003) also examines the relationship between economic freedom, as measured by the Gwartney \& Lawson (2001) index and investment (\% of GDP). He noted that the general level of economic freedom causes investment, as does freedom in the field of 
Ivana Brkić

"international finance". "Government size" and the "international market" in the context of economic freedom are also strongly linked to investment, but they are caused by investment. The recommendation, in the light of this knowledge, is that a policy of stimulating the international flow of capital would be crucial for promoting investment. The author provides evidence that a change in the general level of economic freedom promotes investment, which implies that a change in "international finances" causes the same. Changes in "government size" and "international market" are the reverse, the consequence of investment. There is no evidence of causality for the other categories. The long-term effects of the general level of economic freedom (as well as the subcategory "international finance") are of no significance for the volume of investment. A change of economic freedom, on the other hand, has a positive effect on investment. Thus, the growth of freedom by $1 \%$, over a period of 15 years, affects the growth of investment (\% of GDP) by $8.5 \%$, while the growth of freedom in the "international finance" segment increases investment by $5.5 \%$.

Dawson (2003) paid attention to determining the causality between economic, political, and civil freedom. He noted that the level of economic freedom causes growth and is at the same time determined by the level of political and civil freedom (with the exception of "international trade" and "international finance", where the results suggest an endogenous relationship with political freedom), while the change of economic freedom is determined by growth.

De Haan \& Sturm (2003) obtained the same results when they present that the growth of economic freedom is driven by the level of political and civil freedom in the example of developed countries. The long-term effects of increase in political/civil liberty by $1 \%$ cause a $0.05 \%$ increase in economic freedom. They have the most significant impact on the growth of freedom in the area of "the use of foreign currency" and the least on the "market use" segment.

A general summary of this significant study (Dawson, 2003) is that institutions thrive together and that political/civil freedoms take precedence in evolution. Friedman (1962) argued for the connection between political and economic freedom, but Dawson (2003) shed light on a new dimension - what is the cause and what is the consequence.

Vega \& Alvarez (2003) also examine causality in the relationship between economic freedom, political freedom, and economic growth. They do so in a sample of 45 countries, 
Ivana Brkić

between 1975 and 1995. The analysis shows that economic and political freedom have a positive impact on economic growth. This could be interpreted as meaning that total freedom has beneficial effects on a country's economy. Moreover, the impact of economic freedom on economic growth almost doubles the effects of political freedom. In other words, institutions that function for the purpose of market liberalization stimulate economic growth more strongly than democracy does, as claimed by Vega \& Alvarez (2003). There is a reciprocal relationship between economic and political freedom: economic freedom increases political freedom, and democratic institutions give a better basis for greater economic freedom. While greater economic growth has a positive and significant impact on political freedom, such growth is not significant for economic freedom, as calculated by Vega and Alvarez (2003). In summary, the results of these authors indicate that intensified democracy can lead to faster growth and greater economic freedom.

Being interested in the topic of causality, Justesen (2008) very thoroughly examined its presence between economic freedom (measured by the Fraser Institute index, Gwartney \& Lawson, 2007) and the average rate of GDP growth per capita at six intervals of five years between 1970 and 1999. By conducting a panel analysis for different groups of countries using the Granger test to examine the direction of causality between economic freedom and economic growth, the author indisputably proved such a relationship (where only one point of growth on the freedom scale brings economic growth of $1.1 \%$ to $1.6 \%)$. Moreover, a positive relationship was also found between some components of economic freedom and economic growth. This primarily refers to the "size of government" and "regulatory policies" that, in addition to economic growth, have a strong impact on investment. Low public spending, lower taxes and liberalization in the business sphere are key determinants of economic growth, according to the study. The author also paid attention to discovering the causes of economic growth from the standpoint of change of economic freedom, where he also drew positive conclusions. The segment related to "business, market and credit regulation" also proved to be significant, and apart from the aspect of level, its change also shows a significant impact on both economic growth and investment.

Analyzing a specific group of countries of the South African Development Community, Gorlach (2011) demonstrated the existence of a causal link between economic freedom and economic growth based on a sample of six member countries. The methodological shortcoming of this study is seen in the use of GDP levels to present 
economic growth, which may be reflected in the conclusions drawn. The second group of countries from the territory of Africa was examined in terms of causality by Ossono (2012). The author also concludes that the group of six countries of Central African Economic and Monetary Community is characterized by a causal link between economic freedom and GDP level.

Based on the structure of the study applied by Heckelman (2000), the first to examine the causality with the Granger test using the Heritage Foundation index, Hristova (2012), twelve years later, sought to determine whether the views about causality between economic freedom and economic growth solidified and/or changed. In a sample of 91 countries from 1994 to 2011, she found that there had been an improvement in the statistical significance of the results on causality between economic freedom and growth compared to the results with $10 \%$ of statistical significance observed by Heckelman (2000). According to her calculations, economic freedom causes economic growth in Granger's sense for (all) three lags at levels of significance of $1 \%, 5 \%$ and $10 \%$. In order to determine which dimension most influences these results, a causality analysis was conducted between each category of economic freedom, as defined by the Heritage Foundation and economic growth. The robustness of results concerning causality in Granger's sense was found in the categories of Fiscal freedom, Monetary freedom and Freedom from corruption, which show a causal link with economic growth at all levels of significance for all three lags. The consistency of the "monetary freedom" link, but only at the $10 \%$ significance threshold, was also established by Heckelman (2000) on a four-year database. Freedom from corruption did not prove to cause growth in the research conducted by Hristova (2012), while other results are not robust. This study further shows that growth causes economic freedom for all three lags with $10 \%$ statistical significance. Property rights and Business freedom show the same characteristics as the overall index in the context of following growth. Financial freedom and Labor freedom show certain structures whereby it may be established that they are preceded by growth, but robustness cannot be claimed for these relationships.

Aixalá \& Fabro (2009) explored causality in the relations of economic freedom, civil liberty and political rights as two dimensions of political freedom and economic growth. Although there are different perspectives on the mentioned relationship that prevails in scientific circles (that democracy obstructs, encourages, or does not guarantee growth), hypothesizing Aixalá \& Fabro (2009), by their sound logic, conclude that a free economy and 
Ivana Brkić

democracy must be in a strong relationship. The independence of the judicial system as one of the basic characteristics of a democratically organized society is essential to an efficient, economically free society. Likewise, protection of property rights is only possible in societies dominated by civil liberties and political rights. In their empirical research, observing the period from 1976 to 2000 in a group of 187 countries, Aixalá \& Fabro (2009) conducted a panel analysis and a Granger causality test. The authors noted that the level of economic freedom establishes a bilateral causal link with growth, with present significance in the long run. These results correspond with the results of the research conducted by Heckelman (2000) and Dawson (2003). Change in the level of economic freedom establishes the same type and strength of link with growth, in line with the scientific contributions of De Haan \& Sturm (2000, 2001), Pitlik (2002) and Sturm et al. (2002). While political rights precede growth, civil liberties establish bilateral causality in a given relationship. Yet, change of these freedoms does not have a causal link with economic growth. Studying the indirect link to growth, Aixalá \& Fabro (2009) explored the relationship between economic freedom and investments in physical and human capital. They found that the level and change in the level of economic freedom had significant long-term effects on investments in both physical and human capital. On the other hand, in the case of civil and political freedom, causality exists only in relation to investment in human capital. Only in the case of economic freedoms does such an indirect driver of economic growth show long-term significance. In the interrelationship of institutional variables in the study conducted by Aixalá and Fabro (2009), the following relations were observed: civil freedom and political rights cause economic freedom, and in the case of political rights, the relationship is bilateral; political rights precede civil freedom.

Since numerous studies had not come to a single conclusion about whether democracy precedes, follows or goes hand in hand with growth in well-being, or whether it has a positive, negative, or any influence at all on economic growth, Piątek, Szarzec \& Pilc (2013) tried to contribute to this topic. The authors examined the causality of the relationship between political, economic freedom and economic growth in 25 transition countries, from 1990 to 2008. The research concluded that political freedom is not the cause (based on Granger's interpretation of causality) of economic growth, but there is reverse causality, that is, economic growth precedes political freedom. More significant conclusions for our field of interest were made by the authors regarding the causality of economic growth and economic freedom. There is strong evidence that economic freedom causes economic growth 
(according to the Granger causality test), and such effect is especially caused by the following sub-indices: Public spending, Monetary freedom, Investment freedom, Freedom from corruption. For public spending and investment freedom, the reverse is also true - they can be caused by economic growth. To sum up, Piątek et al. (2013) concluded that economic freedom has a strong impact on economic growth in transition economies (the same as in developed countries) and, considering the whole period since the introduction of transition, on average, economic freedom has a positive impact on the pace of economic growth.

\subsubsection{EXAMINING THE RELATIONSHIP BETWEEN POLITICAL FREEDOM, ECONOMIC FREEDOM AND ECONOMIC GROWTH}

Not by addressing issues of causality (in statistical terms), but by considering theoretical notions, Gwartney et al. (1996) distinguish between economic, political and civil freedom. They interpret that political freedom refers to the right of all adult citizens to participate in the political process, elect government officials who will make decisions on important political issues. In the case of political freedom, elections are fair and competitive and alternative parties have the right to vote. Civil freedom, they explain, is reflected in freedom of the press, freedom of speech, religion and assembly, the right to life, self-defense and fair trial. Based on all of the above, Gwartney et al. (1996) conclude that a country may have a significant level of political and civil freedom but still adopt and implement policies that are contrary to economic freedom. Political freedom can coexist with low levels of economic freedom (eg India), just as economic freedom can exist in the absence of political freedom (eg Singapore), as stated by Swaleheen \& Stansel (2007).

Ali \& Crain (2001) also argue that even very democratic countries, with a high degree of political and civil freedom, can adopt economic policy that will lead to reduction in investment and distortion of resources, while autocratic regimes can implement an effective economic policy which encourages private initiative and investment, thus accelerating the pace of economic growth. This is explained by the fact that dictatorial regimes, due to the absence of a process of confrontation with political opposition, are able to implement market reforms faster than democratic countries. By empirical analysis on a sample of 119 countries in the period between 1975 and 1989, Ali \& Crain (2001) came to the conclusion that political regime and civil freedom, unlike economic freedom, are not key determinants of 
economic growth. They also concluded that the quality of economic infrastructure is not necessarily linked to the political regime or level of civil freedom, and that the effects of economic freedom on growth do not depend on the level of political and civil freedom.

Guided by the model developed by Gwartney et al. (2006), Chu \& Kong (2009) made a regression model of independent variables of neoclassical growth theory and geographic/location variables, after which they added representatives of institutional variables: economic freedom of the Fraser Institute and political freedom of the Freedom House, as well as the mutual relationship between them. The authors also divided the group of 92 countries into more developed and less developed ones. Looking at them in the period between 1970 and 2000, the authors find that the impact of economic freedom is more significant than political freedom, and that it is more pronounced in less developed countries. Thus, while the growth by one unit on the economic freedom scale leads to economic growth of $0.83 \%$ in all countries, in the less developed ones it is $1.31 \%$. Combining the impact of political and economic freedom on economic growth, Chu \& Kong (2009) arrive at the following results. The impact of political freedoms on growth is statistically significant only in the group of countries that do not have economic freedom. This essentially means that in countries that reach a certain (or high) level of economic freedom, the growth of political freedom does not contribute to economic growth. This statement is supported by evidence that no matter what the level of political freedom in a country is, economic freedom is one that will have effects on economic growth, although that growth is more pronounced in politically freer countries.

Since free markets and democracy are compatible in most of the world, it was expected that former socialist countries would transition to both capitalism and democracy. This has not happened in all countries. Out of a desire to compare whether countries which, with the fall of socialism, embraced democratic political order or, like China and Singapore which retained dictatorship and opened markets, achieved faster economic growth, Peev \& Mueller (2012) conducted a study. They started with an assumption that democracy would lead to an increase in economic freedom, resulting in faster economic growth. Democracy can also lead to a large public sector and large public expenditure, which slows economic growth. Therefore, they explored the link between democracy, economic liberalization and growth, as well as democracy, public expenditure and economic growth. The result was that the democratic system did not follow the process of economic liberalization in the countries 
Ivana Brkić

of the former Soviet Union of the Socialist Republics (USSR), except for the three Baltic States (Estonia, Latvia and Lithuania). Scientists even attribute the success of the Baltic countries to the geographical proximity to the European Union, although they do not rule out the possibility of credit for growth to some other more favorable conditions that these countries have compared to the rest of the former USSR. The authors established a strong link between economic freedom and democracy, in the sense that economic freedom is greater and corruption less in more democratic countries. This result could also be attributed to the conditions for accession to the European Union (reduction of corruption and greater economic freedom). Yet Bulgaria and Romania, although EU member states, have low levels of economic freedom, weak democratic institutions and are in the grip of corruption, which confirms the thesis that it is the democratic system itself that has a stake in creating a more economically free society. This link between democracy and economic freedom leads to a link between democracy and economic growth, because economic liberalization, as proved by the authors, produces faster economic growth.

Conducting an analysis in twenty-four transition countries from 1994 to 2007, Peev \& Mueller (2012) find that economic growth is driven most by monetary and trade freedom, as well as by freedom from corruption, while others have little or no effect on economic growth. These categories of economic freedom stimulate investment, after which they represent growth generators.

Analyzing the impact of economic freedoms on GDP growth in transition countries after the financial crisis (2008-2009), the same authors (Peev \& Mueller, 2012) conclude that countries that were trade and monetary freer paid a higher price for liberalization through more dynamic decline in growth rates. In other words, economic liberalization and a small public sector lead to greater economic growth in normal times, while transition countries are more vulnerable in times of crisis, leading to higher government spending to mitigate the effects of the crisis. Peev \& Mueller (2012), in a simplified overview, make a conclusion that the former communist countries, which are at a higher level of democracy, achieve greater economic growth, while on the other hand, democracy contains elements that lead to its slowdown. 
Table 8 provides a concise and symbolic overview of the interconnections between economic freedom, political freedom, and economic growth, according to the scientific contributions of the authors whose work is analyzed in this dissertation.

Table 8. Overview of the interconnections between economic freedom, political freedom and economic growth in the studies presented

\begin{tabular}{|c|c|}
\hline Authors & $\begin{array}{l}\text { The interconnections between economic freedom, political } \\
\text { freedom and economic growth }\end{array}$ \\
\hline $\begin{array}{c}\text { Farr, Lord \& } \\
\text { Wolfenbarger (1998) }\end{array}$ & economic freedom $\leftrightarrow$ GDP $\rightarrow$ political freedom \\
\hline Vega \& Alvarez (2003) & economic freedom $\rightarrow \Delta \mathrm{GDP} \leftrightarrow$ political freedom \\
\hline Aixalá \& Fabro (2009) & 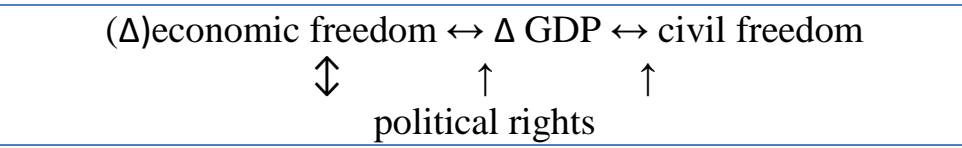 \\
\hline Peev\&Mueller (2012) & political freedom $\rightarrow$ economic freedom $\rightarrow \Delta \mathrm{GDP}$ \\
\hline $\begin{array}{l}\text { Piątek, Szarzec \& Pilc } \\
\text { (2013) }\end{array}$ & economic freedom $\rightarrow \Delta \mathrm{GDP} \rightarrow$ political freedom \\
\hline
\end{tabular}

Source: Author 


\subsubsection{EXAMINING THE STATE AND IMPACT OF ECONOMIC FREEDOM WITHIN DIFFERENT GROUPS OF COUNTRIES}

Analyzing the impact of economic freedom on the situation or changes in the economy, some authors have chosen to test such relations in specific areas, socio - political economic groups of countries or in particular geographical regions. As this was the aspiration of the author of the dissertation to establish links between economic freedom and economic growth within a geopolitical as well as socio-economic area - member states of the European Union, special attention was paid to scientific studies that also dealt with this topic within the same or another area whose knowledge is presented below in the dissertation (Table 9).

\subsubsection{IMPACT OF ECONOMIC FREEDOM IN EUROPEAN COUNTRIES}

Few studies have paid attention to examining the impact of economic freedom in the European area as a whole, but certain groups within the given area (European Union countries, European transition countries, etc.) have been the focus. Below is an overview of the results of studies on the achieved relationship between economic freedom and various economic indicators within Europe.

Rajasalu (2003) examined what are the determinants of economic growth in 28 EU Member States, some of which were candidates at the time of the study. Panel analysis showed that economic freedom had a statistically significant and positive effect on economic growth, regardless of model specification, but that the explanation of the variability of the dependent variable was very small in all regression models. This suggests that there are other factors not covered by this analysis that affect economic growth. Fiscal freedom showed that it would contribute most to economic growth, increasing it by $1.87 \%$ if the value of a given component moved up one notch. Monetary and Financial freedom would have a similar impact on economic growth, while other aspects of freedom according to the division of the Heritage Foundation did not show statistical significance.

The European Union means a free trade zone, a customs union and, for sixteen countries, a monetary union. Likewise, the common agrarian policy that involves interventionism in the form of subsidies to producers, as well as some aspects related to the 
Ivana Brkić

harmonization of labor market standards, are not in line with the paradigm of economic freedom. For this reason, Hall, Lawson \& Wogsland (2011) wanted to investigate whether joining the European Union had the effect of increasing economic freedom, and consequently economic growth. This panel analysis showed that membership of the European Union has an effect of increasing economic freedom, but that this effect is (econometrically) small.

Altay \& Çelebioğlu (2011) considered the influence of geographical location on the development of countries. They concluded that there is a development gap between the countries of Eastern and Western Europe. The authors also find that a country's geographical position affects its GDP per capita, economic freedom index and democracy index. So they found that the least developed countries are countries of Eastern Europe, namely: Albania, Moldova, Montenegro, Serbia and Ukraine, and the most developed are Belgium, Denmark, France, Germany and the Netherlands. According to the authors' analysis, these countries of Western Europe, especially France and Germany, are the drivers of economic development.

It has been proven repeatedly that economic freedom can stimulate economic growth, which also benefits lower-income population, thereby indirectly reducing economic inequality within society. Yet, there is evidence of the opposite (negative) consequences of the growth of economic freedom on the area of economic inequality. Because of such uneven attitudes to this issue, Pérez-Moreno \& Angulo-Guerrero (2016) decided to make their scientific contribution, and they established a positive relationship between economic freedom and inequality, in the sense that greater economic freedom implies greater economic inequality. For research purposes, they used panel data, and presented economic freedom with the help of both major measures of economic freedom - the Hermitage Foundation and the Fraser Institute, while also analyzing the impact of five separate components of economic freedom according to the Fraser Institute. The sample included 28 EU Member States, while the sample observation period was from 2000 to 2010. In accordance with the above, the authors came to the following results. Although both indices of economic freedom exhibit a positive link to inequality, certain aspects of economic freedom act differently. Thus, economic inequality and the aspect of government spending whose minimization symbolizes greater economic freedom are in a negative relationship. This sheds light on the claim that large public spending, based on transfer payments and services (health care, education, social assistance to the disadvantaged) has positive effects on reducing inequality. In line with Ang's conclusion (2010) that the development of the financial market reduces inequality, 
Ivana Brkić

whereas its liberalization increases it, Pérez-Moreno \& Angulo-Guerrero (2016) find that less regulation of the goods, money and labor markets (in the context of greater economic freedom) leads to greater inequality. As this sector covers a wide range of regulations regarding labor market regulation, such as dismissal policy, the amount of minimum rents, the result of a positive correlation with inequality is not surprising. While a greater level of economic freedom leads to greater stability of money, this phenomenon, according to the authors' calculation, albeit disproportionately (and unexpectedly) leads to an intensification of economic inequality. The justification for such results can be found in changes in the monetary policy area in order to achieve price stability, while these changes may lead to increased inequality. Although significant segments of the EU's core values - the legal system and property rights, as well as freedom in international trade, these aspects of economic freedom did not emphasize statistical significance in relation to economic inequality.

Although these results are significant and among the first to address the issue of the relationship between economic freedom and economic inequality within the EU, it should be borne in mind that they can be neither generalized nor applied individually to each country. Furthermore, given relationships were studied in the short run, which certainly distorts the final picture of the true nature and importance of the link (in the long run) between economic freedom and economic inequality, since both variables are linked to economic growth. In addition, Europe was hit by the recession at the end of the first decade of the 21 st century, which resulted in a decline in economic activity, increased unemployment and rising public debt in most countries, and thus indirectly in a shift in distribution and redistribution.

\subsubsection{IMPACT OF ECONOMIC FREEDOM IN COUNTRIES IN TRANSITION}

The transition period proved to be suitable for examining the impact of economic liberalization on economic flows. The process of transition from a planned economy to a free market, from social/state ownership to predominantly private ownership, should ensure more efficient business operations, the absence of corruption and, overall, a more economically liberal society that has positive effects on the economy. With this idea in mind, many authors have observed changes in countries in transition, in order to see the importance of such transformation on the economic situation of the countries mentioned. 
Ivana Brkić

A high level of correlation between economic freedom and numerous macroeconomic indicators for each of the analyzed countries in transition in South East Europe was noted by Vukotić \& Baćović (2006). Ten Central and Eastern European countries showed a strong correlation between economic freedom and economic growth in the study by Próchniak (2011). Subsequent regression confirmed this relationship and showed a positive, statistically significant impact of economic freedom on economic growth for the mentioned group of countries in transition.

Pääkkönen (2009) investigated how economic freedom influenced the growth of GDP per worker in a sample of 25 transition countries by analyzing the period 1998-2005. Over the set of panel data, the author formed a regression model rich in control variables and came to the conclusion that economic freedom has a positive effect on economic growth. The robustness of these results was also confirmed when countries rich in natural resources - oil were excluded from the analysis. Public spending proved to have a positive effect on productivity growth, but also to reduce the positive impact of economic freedom when they interact. The contribution to productivity growth is weaker when economic freedom interacts with investment. In order to test robustness, the author later set real GDP growth per capita as a dependent variable, but the results he obtained were very similar to previous ones.

In the study of the impact of economic freedom on economic performance in centrally dominated economies conducted by Kovačević \& Borović (2014), the authors came up with some interesting results. The countries examined were countries of former socialism, namely Bulgaria, Croatia, the Czech Republic, Estonia, Hungary, Latvia, Lithuania, Poland, Romania, the Slovak Republic and Slovenia, today all full members of the European Union. The research covered the period between 2000 and 2013. The results show a positive impact of economic freedom on GDP, which is not statistically significant. The same results were obtained in the analysis of the impact on GDP per capita. A more detailed analysis of the structure of economic freedom revealed the different impact of index components on the economic performance of the given countries.

Analyzing the pillars of economic freedom as seen by the Heritage Foundation, the authors concluded that Rule of Law (property rights, freedom from corruption) and Regulatory Efficiency (business freedom, labor freedom, monetary freedom) have a negative impact on economic performance, with the first pillar not expressing statistical significance. 
These results are strange, so the authors announce the continuation of research in order to find acceptable interpretations. Pillars Limited Government (fiscal freedom and public spending) and Open Markets (investment freedom, trade freedom and financial freedom) show a positive and statistically significant impact on economic performance.

Bayar (2016) also examined the impact of economic freedom on economic growth in countries undergoing the transition process. Based on data from 1996 to 2012, he observed 11 such countries, which are also members of the European Union. Bayar (2016) reaffirmed his assumption that economically freer countries and countries with greater international exchange have higher economic growth. He also noted that financial openness has an adverse effect on the economic growth of countries in transition.

We remind that Piątek et al. (2013) established a causal link between economic freedom and economic growth in a group of 25 transition countries observed from 1990 to 2008. The authors singled out Public Spending, Monetary Freedom, Investment Freedom and Freedom from Corruption as segments of economic freedom that stand out especially in the causal link with economic growth in the countries observed.

\subsubsection{IMPACT OF ECONOMIC FREEDOM IN THE SOUTH AMERICAN REGION}

There is (not only) a scientific dilemma as to whether implementing policies that liberalize the economy helps South American countries reach North American development levels. Some countries, such as Chile, Bahamas, Colombia, rank very high on economic freedom lists, while other countries are highly repressive (eg Cuba, Venezuela, Argentina, Bolivia, Equador). This makes this area very interesting to research and analyze whether economic freedom really affects the intensity of growth. More important than this question is the question of which policy has an impact and in what way, as it has been repeatedly proven that not all aspects of economic freedom are equally deserving of economic growth, nor can it be uniformly claimed for all countries and regions. Attempts to answer these questions were made by Bengo \& Sanchez-Robles (2003) and Alexandrakis \& Livanis (2013).

Bengoa \& Sanchez-Robles (2003) were among the first to investigate the impact of economic freedom on economic growth, both directly and through the impact on foreign 
direct investment. They concluded that in both cases economic freedom contributes to economic growth. They also confirmed the well-known findings that foreign direct investment has a favorable impact on the economy. Through a panel analysis, they observed the movements of the described relationships in 18 Latin American countries from 1970 to 1999.

Alexandrakis \& Livanis (2013) examined whether a more liberal policy would lead to higher labor productivity expressed by total factor productivity, human capital, and capital intensity. Such testing was performed using panel analysis in Latin American and Caribbean countries and OECD countries. They came to the conclusion that economic freedom expressed by the Fraser Institute chain index would lead to economic growth through total factor productivity in OECD countries and through human capital in Latin American countries. Reduced government spending would drive productivity in Latin America, but not in OECD countries. Low, stable inflation showed a positive, statistically significant impact on the output per worker. Both aspects of freedom will form a greater output per worker by improving the total factor productivity. International trade showed positive results in OECD countries, but not in Latin America. Previously, there had also been theoretical and empirical evidence that openness in terms of international trade had positive effects in developed but negative in underdeveloped countries (e.g. Kim, Lin \& Suen, 2011). Expressed property rights had positive effects on the productivity of workers in both regions. The study showed that deregulation of the labor market, capital and business raise the intensity of capital but reduce the total factor productivity in both sets of countries.

\subsubsection{IMPACT OF ECONOMIC FREEDOM IN ISLAMIC COUNTRIES}

Most Islamic countries are characterized by marked traditionalism and conservatism, high natural growth, large reserves of oil and gas, and largely undemocratic political system, accompanied by relatively volatile socio-political circumstances. The authors who studied the status and impact of the economic freedom of this group believed that these characteristics could have determinative effects on the state of economic freedom and, indirectly, on the level of economic development of those countries. 
A comparative analysis of 103 countries grouped into five sets of countries based on the Economic Freedom Index of the Heritage Institute was performed by Peláez (2009). The comparison was made against the reference group of most free countries: Hong Kong, Singapore, Australia, USA, New Zealand, United Kingdom and Ireland. Other groups included "mostly free" countries (23), Latin American countries (19), Islamic countries (43) and EU member states which are below the level of "mostly free" countries (13 countries, most of which were part of the former USSR).

The reference group recorded the highest values in the area of business freedom and property rights, while the lowest ranked segment is related to public spending which is a characteristic of both Islamic and Latin American countries. In terms of overall degree of freedom, all countries showed lower values than the reference values. Countries from the "mostly free" group have lower values in the area of labor freedom, investment freedom and public spending. Latin American countries and those in which Islam is the dominant religion do not only differ from the leading group of countries in terms of fiscal freedom and public spending. Newer member states of the European Union follow the reference countries as regards trade freedom and fiscal freedom. The Islamic group of countries is less free compared to Latin American countries and "newer" EU member states. Peláez (2009) explains the low level of freedom of the Islamic and Latin American group of countries by historical and socio-political circumstances. The author noted that there is a very large difference between countries with a high score on the economic freedom scale and Islamic countries in the segments related to property rights protection and corruption. As Peláez (2009) explains, in Islamic countries, according to the Quran, Allah is the absolute owner of everything on earth and gives individuals conditional property rights in respect of possession, enjoyment and transfer. Moreover, property must serve a higher social purpose, not for profit, which is a secular concept and at the heart of a capitalist laissez faire society. With high levels of corruption, these beliefs influenced the continued decline in economic freedom in Islamic countries, as interpreted by Peláez (2009).

Economic freedom in Islamic countries was also addressed by Türedi (2013). He studied the impact of both dominant indicators of economic freedom on per capita GDP by applying a panel method on a sample of 12 Islamic countries from 1995 to 2010 . He came to the conclusion that both indices show a positive and statistically significant impact. 


\subsubsection{IMPACT OF ECONOMIC FREEDOM IN AFRICAN COUNTRIES}

Bearing in mind that during most of the 20th century African countries were under the colonial rule of different European countries, that is, during that period their economic and other development were permanently hampered, they are still characterized by low levels of economic development and living standards, but also by unstable political-social circumstances and limited human rights and freedoms. Also, the characteristics of the mentioned countries are related to the absence of significant natural resources, as well as to the pronounced ethnic and religious diversity accompanied by frequent tribal conflicts. Their attributes and efforts towards economic development inspired certain authors to study the state of economic freedom in these countries and to identify the effects of economic liberalization on the development of their economies.

N'Zue (2011) studied the former colonies of England and France that today belong to the Economic Community of West African States (ECOWAS). The author concluded that economic freedom has a positive but not statistically significant impact on the economic performance of former colonial countries. Moreover, the author found that the level of economic activity is the one that affects the level of economic freedom of the countries observed. However, some elements of economic freedom show a positive and statistically significant impact on the level of GDP within this economic community. Thus, the level of public spending, as well as monetary and fiscal freedom, have more effect on the economies of the countries that were British colonies than in the French-speaking countries. The author also found that colonialism cannot be blamed for the low level of GDP per capita in these countries. The process ended in the 1960s and was not proved to have affected economic performance in the observed period from 1995 to 2008.

In a sample of 6 countries of the Central African Economic and Monetary Community (CEMAC), Ossono (2012) confirmed that in this group of countries of the African region, economic freedom has a positive, statistically significant impact on GDP per capita.

By performing a panel analysis on a sample of seven selected member countries of the Organization of the Petroleum Exporting Countries (OPEC), looking at the period from 2000 to 2009, Ahmadpour, JafariSamimi \& Refaei (2013) conclude that economic freedom influences (positively and statistically significantly) economic growth. However, in line with 
Ivana Brkić

many other scientific findings, the authors recognize that not all elements have equal (statistical) significance. Out of the seven aspects of economic freedom unified by the Fraser Institute within its index, the authors examine five of them. They find that "government size" has a positive but not statistically significant impact on growth. "Legal system and property rights", as well as "sound money", but also "regulation of credit, labor and business" have a positive and statistically significant impact. Only "freedom to trade internationally" in this study has a negative (statistically significant) relationship with growth, reducing it by $0.12 \%$ with the growth of index by one unit. These results are surprising given the formal name and preference of countries within the organization which base their economies on oil exports.

Observing the period from 2000 to 2009 and a specific group of countries, Panahi et al. (2014) found that growth by one index point on the economic freedom scale leads to economic growth by $1.22 \%$. The research was conducted in 13 Middle East and North Africa (MENA) countries. By decomposing the components of the economic freedom index created by the Fraser Institute, scientists obtain results somewhat contradictory to those found so far in the literature. They noted that the size of government shows no significance while the value of the coefficient is positive. Legal structure and property rights are in a significant, negative relationship, and the results indicate that one unit increase of the index reduces the growth rate by $0.07 \%$. This result was somewhat surprising to the authors, as most of the previous studies showed a positive or independent relationship. Sound money and freedom to trade internationally are in a positive, statistically significant correlation with growth, as is the regulation of credit, labor and business, whose growth in freedom by one unit affects the economic growth by $0.63 \%$.

In a group of 12 countries in the Southern African Development Community (SADC) in addition to the causal link between the Fraser Institute's aggregate economic freedom index and per capita GDP, Gorlach \& Le Roux (2015) found a positive and statistically significant impact of all five components of the given index.

Recently, Zghidi, Mohamed Sghaier \& Abida (2016) have examined the impact of foreign direct investment and economic freedom on economic growth in a group of four North African countries (Tunisia, Morocco, Algeria, Egypt). Covering the period from 1980 to 2013, using the Generalized Method of Moments (GMM), they concluded that foreign 
direct investment has a positive and statistically significant impact on economic growth, and that this impact is increased in the presence of economic of freedom.

\subsubsection{IMPACT OF ECONOMIC FREEDOM IN THE ASIAN REGION}

Asia is the largest and most populous continent in the world, with more than 4 billion inhabitants, or approximately two thirds of the world's population, and its national, religious and linguistic composition is more diverse than on any other continent. Asia is also characterized by major economic and social contradictions, so countries such as Japan, Singapore and South Korea are among the most developed economies in the world, with China, which can also be included in this group despite the fact that the country is characterized by a repressive socio-political system and extremely limited scope of economic freedom. On the other hand, North Korea, Afghanistan, Nepal and Myanmar are among the poorest countries in the world.

Examining the state of political, civil and economic freedom in five countries belonging to the South Asian Association for Regional Cooperation (SAARC), Khan (2012) concludes that it is economic freedom that will lead to the advancement of political and indirectly civil freedom, and that the liberalization of economic activities is a major recommendation for policymakers. As stated by Haydaroglu (2016), Mahmood, Azid, Chaudhry \& Faridi (2010) found that in the same group of countries (Bangladesh, India, Nepal, Pakistan, Sri Lanka) the most significant contribution to economic growth is made by the categories of financial and trade freedom, investment freedom, business, freedom from corruption and protection of property rights, while the size of public spending has a negative link with economic growth. Nasir \& Hassan (2011) also addressed the state of economic freedom in South Asian countries and their impact on foreign direct investment. They noted a positive and statistically significant relationship, and suggested that improving the investment climate was based on improving the economic freedom of each of these countries. Sarvananthan (2004) also paid attention to this group of countries with particular reference to Sri Lanka, pointing to additional dimensions of economic freedom which, according to the author, should be included in the indicators of economic freedom given the specificity of this country. Here he was primarily referring to media freedom as well as the impact of the two- 
decade civil war, which undoubtedly had consequences for the economic situation in the country.

Tiwari (2011) studied the impact of certain components of economic freedom, foreign aid and foreign direct investment on economic growth within 28 Asian countries. He came to the conclusion that there is a positive and statistically significant relationship between fiscal as well as financial freedom and economic growth. Negative impact was observed in freedom from corruption, as well as in foreign direct investment and foreign aid received by these countries. For the latter, a particularly negative impact was observed when it comes to the high inflow of economic assistance.

A very specific group of countries is the so-called Asian Tigers, including Hong Kong, Singapore, Taiwan, South Korea, and Japan, whose cause of rapid economic growth in the last four decades was particularly studied by Paldam (2003). These countries are characterized by low levels of public spending, equal distribution of income and high savings rates. The author noted that the two cities - states (Hong Kong and Singapore) are primarily trade nations with distinct property rights, in terms of the laissez-faire concept most similar to the United States. South Korea and Taiwan, on the other hand, are more similar to European countries (eg France and the Scandinavian countries), which have a slightly lower level of economic freedom.

Economic freedom proved to be a positive and statistically significant determinant of GDP attained in five emerging economies: Brazil, Russia, India, China and South Africa (the so-called BRICS). Looking at the given impact as well as the impact of foreign direct investment on economic growth, Haydaroglu (2016) found that only public spending has a negative (statistically significant) impact, while other aspects of economic freedom (monetary, business, trade freedom and protection of property rights) have a positive impact on the level of economic output.

\subsubsection{IMPACT OF ECONOMIC FREEDOM IN NORTH AMERICA}

North America includes the second and third largest countries in the world, i.e. Canada and the United States of America. For several decades, the United States has been a 
Ivana Brkić

leading global power, especially in economic and military terms, while Canada, despite its significantly smaller population and far scarcer natural resources than its southern neighbor, has also positioned itself among the most developed economies on the planet, with extremely high standards of living. In addition, the United States and Canada are characterized by high degrees of economic freedom, with the level of the same being slightly lower in Canada, primarily due to higher levels of public spending and less flexible labor market.

Compton, Giedeman \& Hoover (2011) investigated the impact of level as well as change in the level of a five-year average of economic freedom over a long period between 1981-2004 on a sample of five U.S. states. They found that the change in level had an impact on the level of total production in the countries, while the level of economic freedom did not show robust results by applying different methods of analysis (least squares method and generalized method of moments). The authors also investigated the impact of certain segments on the size of economic activity. Government size, embodied in public spending, transfers, subsidies and social security (as \% of GDP), showed a significant impact on GDP size. This confirmed the view that, in addition to government spending, it is necessary to ensure the functioning of the basic functions of the state (defense and the legal system for the protection of property rights, as well as the provision of public goods), excessive public spending impairs economic freedom and threatens economic progress. Although economic freedom entails lower taxes in order to preserve personal choices, this component did not prove statistically significant in observing its impact on the level of total production in the presented sample of countries. Some aspects of labor freedom, such as absence of minimum wage regulations, showed an impact on the economy in five US countries, while other aspects (union strength and number of employees in public sector) did not show statistical significance. The overall conclusion of this study is that the aggregate index needs not be a precise indicator of the economic growth of certain countries and that it is necessary to specify those aspects of economic freedom that determine the achieved scope of economic activity in the countries observed.

Karabegovic, Samida, Schlegel \& McMahon (2003) observed how the level and growth of economic freedom affect the level and growth of GDP in 10 Canadian provinces and 50 US states. They came to the conclusion that in all combinations the positive and statistically significant impact of economic freedom on the level and growth of economic activity in the observed area of North America was expressed. They found that Canada had a 
lower level of economic freedom, manifested in higher taxes, higher public spending and a more rigid labor market than America. The authors believe that lowered economic freedom, according to the results, determines the lower standard of living of the citizens of the Canadian provinces relative to the inhabitants of America.

Bennett (2016) analysed the same area of North America between 1981 and 1997 and also concluded that economic freedom had a positive and statistically significant impact on GDP per capita. This was particularly true of segments of government size restrictions and of labor market-oriented freedom. He also found that economic freedom negatively was related to unemployment in these territories, but also that the growth of economic freedom led to an increase in unequal distribution of income, especially in the United States.

Bayar \& Aytemiz (2015) conducted an interesting study examining the impact of economic freedom in the US on the economic growth of 7 Asian countries. The authors found a positive, statistically significant impact, although the authors' work lacked a deeper interpretation of the results obtained and the link between economic freedom in one part and the economic growth of another part of the world, although the concept of globalization is a logical explanation for this outcome. 
Table 9. Tabular overview of conducted research on the relationship between (change of) economic freedom and economic level and/or growth within different group of countries

\begin{tabular}{|c|c|c|c|c|c|c|}
\hline AUTHOR(S) & SAMPLE & $\begin{array}{l}\text { RESEARCH } \\
\text { PERIOD }\end{array}$ & METHOD & $\begin{array}{l}\text { DEPENDENT } \\
\text { VARIABLE }\end{array}$ & INDEPENDENT VARIABLES & EFFECTS \\
\hline Tiwari (2011) & 28 Asian countries & $1998-2007$ & $\begin{array}{c}\text { Panel analysis } \\
\text { Generalized method of moments }\end{array}$ & $\begin{array}{l}\text { Annual GDP per } \\
\text { capita growth rate }\end{array}$ & $\begin{array}{l}\text { IEF of the Heritage foundation: } \\
\text { Investment freedom } \\
\text { Business freedom } \\
\text { Trade freedom } \\
\text { Financial freedom } \\
\text { Freedom from corruption } \\
\quad \text { Fiscal freedom } \\
\text {----------------- } \\
\text { Foreign aid } \\
\text { FDI net inflows (\% of GDP) } \\
\text { Gross capital formation (\%of GDP) } \\
\text { Fertility rate } \\
\text { Life expectancy }\end{array}$ & Different. \\
\hline \multicolumn{7}{|c|}{$\begin{array}{l}\text { There is a negative and statistically significant link between freedom from corruption and economic growth. There is a negative and statistically significant relationship between foreign aid and } \\
\text { economic growth. There is a positive and statistically significant relationship between fiscal and financial freedom and economic growth. }\end{array}$} \\
\hline N'Zue (2010) & $\begin{array}{c}12 \\
\text { Economic } \\
\text { Community of West } \\
\text { African countries }\end{array}$ & $1995-2008$ & Panel analysis & GDP per capita & $\begin{array}{l}\quad \text { IEF of the Heritage foundation: } \\
\text { Employment } \\
\text { Gross capital formation (\%of GDP) } \\
\text { Binary variables for French and } \\
\text { English colonies } \\
\text { Openness } \\
\text { Human capital } \\
\end{array}$ & $\begin{array}{l}\text { Not } \\
\text { statistically } \\
\text { significant. }\end{array}$ \\
\hline \multicolumn{7}{|c|}{$\begin{array}{l}\text { Economic freedom has a positive but not statistically significant impact on GDP per capita. Public spending and monetary freedom affect the former English colonies. Fiscal freedom affects the } \\
\text { former French colonies. Colonialism has no effect on economic performance in the given countries. }\end{array}$} \\
\hline $\begin{array}{l}\text { Gorlach \& Le } \\
\text { Roux (2013) }\end{array}$ & $\begin{array}{l}13 \\
\text { Southern African } \\
\text { Development } \\
\text { Community }\end{array}$ & $2000-2009$ & $\begin{array}{c}\text { Panel analysis } \\
\text { Ordinary least squares } \\
\text { LSDV } \\
\text { Generalized method of moments }\end{array}$ & GDP per capita & $\begin{array}{l}\quad \text { IEF of the Fraser Institute: } \\
\text { Past GDP } \\
\text { Public spending } \\
\text { Public debt } \\
\text { Gross capital formation (\%of GDP) } \\
\text { Openness (International trade) }\end{array}$ & Positive. \\
\hline
\end{tabular}


The relationship between economic freedom and economic growth in EU countries

\begin{tabular}{|c|c|c|c|c|c|c|}
\hline AUTHOR(S) & SAMPLE & $\begin{array}{l}\text { RESEARCH } \\
\text { PERIOD }\end{array}$ & METHOD & $\begin{array}{l}\text { DEPENDENT } \\
\text { VARIABLE }\end{array}$ & INDEPENDENT VARIABLES & EFFECTS \\
\hline Ossono (2012) & $\begin{array}{c}6 \\
\text { Central African } \\
\text { Economic and } \\
\text { Monetary } \\
\text { Communities }\end{array}$ & $1995-2008$ & $\begin{array}{l}\text { Panel analysis } \\
\text { Ordinary least squares } \\
\text { (fixed effects model) }\end{array}$ & GDP per capita & $\begin{array}{l}\text { IEF of the Heritage foundation } \\
\text { Foreign direct investment } \\
\text { Gross capital formation (\%of GDP) } \\
\text { Inflation } \\
\text { GDP growth rate } \\
\text { Population growth } \\
\text { Foreign development aid } \\
\text { Interest rate }\end{array}$ & Positive. \\
\hline \multicolumn{7}{|c|}{$\begin{array}{l}\text { Economic freedom expressed by IEF of the Heritage Foundation has a positive and statistically significant impact on GDP per capita. There is a causal link between economic freedom and GDP } \\
\text { levels. }\end{array}$} \\
\hline $\begin{array}{l}\text { Ahmadpour, } \\
\text { JafariSamimi \& } \\
\text { Refaei (2013) }\end{array}$ & 7 OPEC countries & $2000-2009$ & $\begin{array}{c}\text { Panel analysis } \\
\text { (fixed effects model) }\end{array}$ & $\begin{array}{l}\text { GDP per capita } \\
\text { growth }\end{array}$ & $\begin{array}{l}\quad \begin{array}{l}\quad \text { IEF of the Fraser Institute } \\
\text { (Gwartney et al 2010) }\end{array} \\
\text { - Number of students enrolled in } \\
\text { high school } \\
\text { - Workforce } \\
\text { - International trade (openness) } \\
\text { - Investment (\% of GDP) }\end{array}$ & Positive. \\
\hline \multicolumn{7}{|c|}{$\begin{array}{l}\text { Total IEF, positive, statistically significant impact on GDP growth. Size of Government - a positive but not statistically significant impact on GDP growth. Legal system and protection of } \\
\text { property rights - a positive, statistically significant impact on GDP growth. Sound money - a positive, statistically significant impact on GDP growth. International trade - a negative, statistically } \\
\text { significant impact on GDP growth. Credit market regulations, labor market regulations and business regulations - a positive, statistically significant impact on GDP growth. }\end{array}$} \\
\hline $\begin{array}{l}\text { Zghidi, } \\
\text { Mohamed } \\
\text { Sghaier \& Abida } \\
\quad(2016)\end{array}$ & $\begin{array}{c}4 \\
\text { North African } \\
\text { countries }\end{array}$ & $1980-2013$ & $\begin{array}{c}\text { Panel analysis } \\
\text { Generalized method of moments }\end{array}$ & $\begin{array}{l}\text { GDP per capita } \\
\text { growth }\end{array}$ & $\begin{array}{l}\quad \begin{array}{l}\text { IEF of the Fraser Institute } \\
\text { (Gwartney et al.2015) }\end{array} \\
\quad \text { Foreign direct investment } \\
\text { Initial GDP } \\
\text { Gross capital formation (\%of GDP) } \\
\text { Number of students enrolled in high } \\
\text { school } \\
\text { Population growth } \\
\text { Openness (international trade) }\end{array}$ & Positive. \\
\hline \multicolumn{7}{|c|}{ Impact of FDI on economic growth is positive and statistically significant, but such impact is amplified by the presence of economic freedom. } \\
\hline $\begin{array}{l}\text { Haydaroglu } \\
\qquad(2016)\end{array}$ & $\begin{array}{c}5 \\
\text { Brazil, Russia, India, } \\
\text { China, South Africa }\end{array}$ & $1995-2013$ & Panel analysis & GDP per capita & $\begin{array}{l}\text { IEF of the Heritage foundation } \\
\text { Public spending; Monetary freedom; } \\
\text { Property rights; Trade freedom; } \\
\text { Business freedom } \\
\quad \text {----------------- }\end{array}$ & Positive. \\
\hline
\end{tabular}




\begin{tabular}{|c|c|c|c|c|c|c|}
\hline \multirow[t]{2}{*}{ AUTHOR(S) } & SAMPLE & $\begin{array}{l}\text { RESEARCH } \\
\text { PERIOD }\end{array}$ & METHOD & $\begin{array}{l}\text { DEPENDENT } \\
\text { VARIABLE }\end{array}$ & INDEPENDENT VARIABLES & EFFECTS \\
\hline & & & & & $\begin{array}{l}\text { FDI } \\
\text { Openness (International trade) } \\
\text { Money supply (\% of GDP) } \\
\text { Electricity consumption per capita } \\
\text { Gross capital formation (\%of GDP) } \\
\end{array}$ & \\
\hline \multicolumn{7}{|c|}{$\begin{array}{l}\text { The Economic Freedom Index has a positive, statistically significant impact on GDP per capita. Monetary, business, trade freedom and protection of property rights have a positive and public } \\
\text { spending a negative, statistically significant impact on GDP per capita. }\end{array}$} \\
\hline Rajasalu (2003) & $\begin{array}{l}28 \\
\text { member states of EU } \\
\text { and its candidates at } \\
\text { the time of } \\
\text { publication of the } \\
\text { paper }\end{array}$ & 1994-2001 & Panel analysis & $\begin{array}{l}\text { Annual GDP } \\
\text { growth rate }\end{array}$ & $\begin{array}{l}\text { IEF of the Heritage foundation } \\
\text { Initial level of GDP } \\
- \text { Export (\% of GDP) } \\
\text { Inflation (\%) } \\
\text { Foreign direct investment (\% of } \\
\text { GDP) } \\
\text { Gross capital formation (\%of GDP) } \\
\text { Export of high technology } \\
\text { Number of computers per } 100 \\
\text { inhabitants } \\
\text { Internet users per } 100 \text { inhabitants }\end{array}$ & Positive. \\
\hline \multicolumn{7}{|c|}{$\begin{array}{l}\text { Economic freedom has a positive and statistically significant impact on economic growth (regardless of model specification), but the explanation for the variance in economic growth across all } \\
\text { models is small. Fiscal freedom, Monetary freedom, and Investment freedom affect economic growth. }\end{array}$} \\
\hline $\begin{array}{c}\text { Bengoa \& } \\
\text { Sanchez-Robles } \\
(2003)\end{array}$ & $\begin{array}{l}18 \text { Latin American } \\
\text { countries }\end{array}$ & $1970-1999$ & Panel analysis & GDP & $\begin{array}{l}\quad \text { IEF of the Fraser Institute } \\
\text { Inflation } \\
\text { GDP } \\
\text { Public debt (\% of GDP) } \\
\text { Public investment (rail) } \\
\text { Binary variable 1980-1985 (debt } \\
\text { crisis) } \\
\text { Binary variable 1990-1995 (Mexican } \\
\text { peso crisis) } \\
\quad \text {---------------------- } \\
\begin{array}{l}\text { Number of students enrolled in high } \\
\text { school } \\
\text { Inflation } \\
\text { Public spending (\% of GDP) } \\
\text { Binary variable 1980-1985 (debt } \\
\text { crisis) }\end{array}\end{array}$ & Positive. \\
\hline
\end{tabular}


The relationship between economic freedom and economic growth in EU countries

\begin{tabular}{|c|c|c|c|c|c|c|}
\hline AUTHOR(S) & SAMPLE & $\begin{array}{c}\text { RESEARCH } \\
\text { PERIOD }\end{array}$ & METHOD & $\begin{array}{c}\text { DEPENDENT } \\
\text { VARIABLE }\end{array}$ & INDEPENDENT VARIABLES & EFFECTS \\
\hline $\begin{array}{c}\text { Alexandrakis \& } \\
\text { Livanis (2013) }\end{array}$ & $\begin{array}{c}23 \text { Latin American } \\
\text { countries and } \\
23 \text { OECD countries }\end{array}$ & $1984-2007$ & Panel analysis & $\begin{array}{c}\text { GDP per worker } \\
\text { (Gwartney et al., 2010) } \\
\text { Institute }\end{array}$ & \\
\hline
\end{tabular}

Economic freedom has a positive impact on productivity in both regions. This is achieved more through overall factor productivity in OECD countries, while in Latin America this is achieved through human capital. Size of Government - positive, statistically significant in OECD countries, but not in LA countries. Legal system and protection of property rights and Sound money positive, statistically significant in both sets of countries. International trade - positive, statistically significant in OECD; negative, statistically significant in LA. Credit market, Labor market, and Business regulation - raises capital intensity but decreases overall factor productivity in both sets of countries.

\begin{tabular}{|c|c|c|c|c|}
\hline Peláez (2009) & $\begin{array}{c}103 \\
\text { Five group of } \\
\text { countries: Freedoms, } \\
\text { Mostly free, Islamic, } \\
\text { Latin American, } \\
\text { certain EU countries }\end{array}$ & 2007 & Ordinary least squares & $\begin{array}{c}\text { IEF of The } \\
\text { Heritage } \\
\text { Foundation }\end{array}$ \\
\hline
\end{tabular}

Binary variables for each group of countries

Islamic countries are the lowest ranked and show the strongest downward trend, while LA countries are stagnant. Somewhat better ranked countries are those that later joined the EU.

\begin{tabular}{|l|l|l|l|l|l|}
\multicolumn{5}{|c|}{ Islamic countries are the lowest ranked and show the strongest downward trend, while LA countries are stagnant. Somewhat better ranked countries are those that later joined the } & IEF of the Heritage foundation
\end{tabular} IEF of the Fraser Institute

Gross capital formation per capita

Human development index

\begin{tabular}{l|l|r|} 
Türedi (2013) & 12 & Panel analysis
\end{tabular}

(fixed effects model)

GDP per capita

Number of Internet users per 100

inhabitants

Domestic credit to private sector $(\%$

of GDP)

Inflation $(\%)$

Openness (international trade)

Economic freedom has a positive and statistically significant impact on economic growth

\begin{tabular}{|c|c|c|c|c|c|c|}
\hline $\begin{array}{l}\text { Hall, Lawson \& } \\
\text { Wogsland (2011) }\end{array}$ & $35 \mathrm{EU}$ countries & $1970-2007$ & Panel analysis & $\begin{array}{l}\text { IEF of The Fraser } \\
\text { Institute }\end{array}$ & $\begin{array}{l}\text { Binary variable for EU member } \\
\text { states. } \\
\text { Binary variable for member states of } \\
\text { EU and Monetary union }\end{array}$ & Positive. \\
\hline
\end{tabular}


The relationship between economic freedom and economic growth in EU countries

\begin{tabular}{|c|c|c|c|c|c|c|}
\hline AUTHOR(S) & SAMPLE & $\begin{array}{l}\text { RESEARCH } \\
\text { PERIOD }\end{array}$ & METHOD & $\begin{array}{l}\text { DEPENDENT } \\
\text { VARIABLE }\end{array}$ & INDEPENDENT VARIABLES & EFFECTS \\
\hline $\begin{array}{l}\text { Próchniak } \\
\text { (2011) }\end{array}$ & $\begin{array}{c}10 \\
\text { Central and East } \\
\text { Europe }\end{array}$ & $1993-2009$ & Ordinary least squares & $\begin{array}{l}\text { GDP per capita } \\
\text { growth rate }\end{array}$ & $\begin{array}{l}\text { IEF of the Heritage foundation } \\
\text { Initial level of GDP } \\
\text { Binary variables for } 2008 / 2009 \text { due } \\
\text { to the impact of the crisis. }\end{array}$ & Positive. \\
\hline \multicolumn{7}{|c|}{ Economic freedom has a positive, statistically significant impact on economic growth. } \\
\hline $\begin{array}{l}\text { Pääkkönen } \\
\text { (2009) }\end{array}$ & $\begin{array}{l}25 \text { countries in } \\
\text { transition }\end{array}$ & $1998-2005$ & Panel analysis & $\begin{array}{l}\text { GDP growth per } \\
\text { worker }\end{array}$ & $\begin{array}{l}\quad \text { IEF of the Heritage foundation } \\
\text { Gross capital formation (\%of GDP) } \\
\text { Public spending (\% of GDP) } \\
\text { Investment (\% of GDP) } \\
\text { Final public spending (\% of GDP) } \\
\text { Human development index } \\
\text { Transition index } \\
\text { Fertility rate } \\
\text { Gini coefficient } \\
\text { Number of students enrolled in high } \\
\text { school }\end{array}$ & Positive. \\
\hline \multicolumn{7}{|c|}{ Economic freedom has a positive, statistically significant impact on productivity growth. } \\
\hline $\begin{array}{l}\text { Kovačević \& } \\
\text { Borović (2014) }\end{array}$ & $\begin{array}{l}\text { 11countries in } \\
\text { transition }\end{array}$ & $2000-2013$ & Panel analysis & $\frac{\text { GDP }}{\text { GDP per capita }}$ & $\begin{array}{l}\text { IEF of the Heritage foundation and } \\
\text { its four pillars. } \\
\text { 1. Investment (\% of GDP) } \\
\text { 2. Inflation }(\%)\end{array}$ & $\begin{array}{c}\text { Positive, } \\
\text { statistically } \\
\text { insignificant. }\end{array}$ \\
\hline \multicolumn{7}{|c|}{$\begin{array}{l}\text { Economic Freedom Index - positive, statistically insignificant. Rule of law - negative, statistically insignificant. Regulatory efficiency - negative, statistically significant. Limited government - } \\
\text { positive, statistically significant. Market openness - positive, statistically significant. }\end{array}$} \\
\hline $\begin{array}{l}\text { Peev \& Mueller } \\
\text { (2012) }\end{array}$ & $\begin{array}{l}24 \text { countries in } \\
\text { transition }\end{array}$ & $\begin{array}{l}1994-2007 \\
2008-2009\end{array}$ & Panel analysis & $\begin{array}{l}\text { Average GDP per } \\
\text { capita growth rate }\end{array}$ & $\begin{array}{l}\text { IEF of the Heritage foundation } \\
\text { - Log GDP with lag length of one } \\
\text { period } \\
\text { - Public spending (\% of GDP) } \\
\text { - Investment (\% of GDP) } \\
\text { - Population growth rate } \\
\text { - Binary variables for each country } \\
\end{array}$ & Positive. \\
\hline
\end{tabular}


The relationship between economic freedom and economic growth in EU countries

\begin{tabular}{|c|c|c|c|c|c|c|}
\hline $\operatorname{AUTHOR}(\mathbf{S})$ & SAMPLE & $\begin{array}{l}\text { RESEARCH } \\
\text { PERIOD }\end{array}$ & METHOD & $\begin{array}{l}\text { DEPENDENT } \\
\text { VARIABLE }\end{array}$ & INDEPENDENT VARIABLES & EFFECTS \\
\hline Bayar (2015) & $\begin{array}{l}11 \\
\text { EU countries in } \\
\text { transition }\end{array}$ & $1996-2012$ & $\begin{array}{l}\text { Cross section analysis } \\
\text { Panel analysis }\end{array}$ & $\begin{array}{l}\text { Annual GDP } \\
\text { growth rate }\end{array}$ & $\begin{array}{l}\text { IEF of the Heritage foundation } \\
\text {--------------------- } \\
\text { Openness (international trade) } \\
\text { Chinn-Ito index (financial openness) }\end{array}$ & Positive. \\
\hline \multicolumn{7}{|c|}{$\begin{array}{l}\text { Economic freedom and openness of the economy have a positive, statistically significant impact on economic growth. } \\
\text { Financial openness has a negative, statistically significant impact on economic growth. }\end{array}$} \\
\hline $\begin{array}{c}\text { Compton, } \\
\text { Giedeman \& } \\
\text { Hoover }(2011)\end{array}$ & 5 US states & $1981-2004$ & $\begin{array}{c}\text { Least squares } \\
\text { Generalized method of moments }\end{array}$ & $\begin{array}{l}\text { Average GDP per } \\
\text { capita }\end{array}$ & $\begin{array}{l}\text { IEF of the Fraser Institute } \\
\text { Karabegovic and McMahon (2005) } \\
\text { Level of EF and change in the level } \\
\text { of EF } \\
\text { Initial GDP per capita } \\
\text { Investment } \\
\text { Education (number of graduates over } \\
25 \text { years of age) } \\
\% \text { of African Americans and Latino } \\
\text { Americans } \\
\text { Urban population }\end{array}$ & Positive. \\
\hline \multicolumn{7}{|c|}{$\begin{array}{l}\text { Change of economic freedom affects the level of GDP. The level of economic freedom has not shown the robustness of results in the application of different methods. } \\
\text { Size of government has a positive and statistically significantly impact on the level of GDP, as do certain segments of labor freedom, while the amount of taxes shows no statistical significance. }\end{array}$} \\
\hline $\begin{array}{l}\text { Karabegovic, } \\
\text { Samida, Schlegel } \\
\text { \& McMahon } \\
(2003)\end{array}$ & $\begin{array}{l}10 \text { Canadian } \\
\text { provinces and } 50 \\
\text { US states }\end{array}$ & $1994-1999$ & Panel analysis & $\begin{array}{l}\text { GDP growth per } \\
\text { capita }\end{array}$ & $\begin{array}{l}\quad \text { IEF of the Fraser Institute } \\
\text { Growth of graduates above } 25 \\
\text { years } \\
\text { Binary variables for Canadian } \\
\text { provinces }\end{array}$ & Positive. \\
\hline \multicolumn{7}{|c|}{ Level and growth of economic freedom have a positive and statistically significant impact on the level and growth of GDP. } \\
\hline Bennett (2016) & $\begin{array}{l}10 \text { Canadian } \\
\text { provinces and } 50 \\
\text { US states }\end{array}$ & $1980-2010$ & Panel analysis & $\begin{array}{c}\text { GDP per capita } \\
\text {------ } \\
\text { Unemployment } \\
\text { rate } \\
\text { Income inequality }\end{array}$ & $\begin{array}{l}\quad \text { IEF of the Fraser Institute } \\
\quad \text { (Stansel and McMahon, 2013) } \\
\quad \text {----------------- } \\
\text { Number of students enrolled in } \\
\text { college } \\
\text { Density of population } \\
\text { Workforce in factories } \\
\text { Female population (\%) }\end{array}$ & Positive. \\
\hline
\end{tabular}


The relationship between economic freedom and economic growth in EU countries

\begin{tabular}{l}
\begin{tabular}{|c|c|c|c|c|c|c|} 
Ivana Brkić \\
\hline $\begin{array}{c}\text { AUTHOR(S) } \\
\begin{array}{c}\text { Bayar \&Aytemiz } \\
\text { (2015) }\end{array}\end{array}$ & $\begin{array}{c}\text { SAMPLE } \\
\text { (economic freedom) } \\
\text { 7 Asian countries } \\
\text { (economic growth) }\end{array}$ & $\begin{array}{c}\text { RESERCH } \\
\text { PERIOD }\end{array}$ & METHOD & $\begin{array}{c}\text { DEPENDENT } \\
\text { VARIABLE }\end{array}$ & INDEPENDENT VARIABLES & EFFECTS \\
\hline
\end{tabular} \\
\hline
\end{tabular}

Source: Author. 


\subsubsection{EXAMINING THE STATE AND CHANGES OF ECONOMIC FREEDOM OF CERTAIN COUNTRIES}

Some authors addressed the question of what impact economic liberalization had had on selected countries, what had brought them positive, what negative, and how such policies and practices had affected the economic situation and changes in those countries. Below are the results of studies that examined the effects of economic freedom in Ireland, today a highly economically free country, Italy and Turkey, moderately free, and Croatia and Bosnia and Herzegovina as still not sufficiently economically free countries. Summarized specific research results are presented in Table 14.

According to Powell (2003), the rapid growth of Ireland's economy is due to an institutional effort to liberalize the economy. Although some aspects of economic freedom had long been present in Irish society, only a balanced, intensive and simultaneous application of all aspects of economic freedom led to economic expansion. The period of protection, typical of the fifth decade of the twentieth century, reflected an economic growth of only two percent. The liberalization of the 1960s contributed to an improvement in economic growth of $4.2 \%$. The liberalization of trade continued in the 1970s, but Keynesian interventionism led to stagnation. High levels of inflation, fiscal instability, high levels of public spending and taxes resulted in economic growth of just 1.9\%, as explained by Powell (2003). Influenced by the fiscal crisis, public spending and, subsequently, taxes were reduced, which led to an increase in economic freedom and, indirectly, to economic progress. "Celtic Tiger" as the author calls it, experienced economic boom in the late 1990s with the synergistic effect of all aspects of economic freedom.

In an effort to examine the contribution of economic freedom to Italy's economic growth, Erdal (2004) performed an analysis, constructing his own index of economic freedom. Covering the period from 1960 to 2000, the author concluded that economic freedom had a positive and statistically significant impact on economic growth, proving the robustness of such results by placing different variants of the economic freedom index in the regression model. The analysis of the partial components of the index showed that the minimization of public spending, a stable legal system and protected property rights, as well as the reduced state intervention in the private sector (taxes, etc.) have a positive impact on 
economic growth. The monetary stability and international trade aspects show positive but not statistically significant results. A feature of the Italian economy is the inefficient collection of taxes, the unproductive use of public resources and the gray economy, although these indicators showed a negative coefficient in relation to economic growth. Another illogicality emerged in examining the impact of the freedom of the capital and investment markets, which showed a negative (not statistically significant) coefficient, although Italy has had a large inflow of capital in recent decades. The author also examined the causality of the relation between economic freedom and economic growth in the example of Italy (in Granger's sense) and proved that economic freedom causes economic growth, while such a relation was not observed in the reverse direction.

Erdal \& Yenipazarli (2013) tried to overcome some of the reasons for the different signs and strengths of the relationship between economic freedom and growth. The three most common causes of diverse results in the authors' view are: the nature of country selection and/or the use of panel analysis, the application of certain indicators (indices) of economic freedom, and the application of the assessment method. Therefore, Erdal \& Yenipazarli (2013) performed a time series analysis between 1970 and 2006 that concerned only one country - Turkey. Moreover, the authors constructed a new index consisting of twenty-eight indicators of economic freedom grouped into six components: government size, interventions in the market, stability of money and banking system, freedom of trade in the capital market, trade freedom, institutional structures. The given components are formed on the basis of the existing economic freedom indices (Heritage Foundation and Fraser Institute) and according to the data available for Turkey. The index thus formed showed a strong, positive and statistically significant link to economic growth. Its individual components are in different relations with economic prosperity. Freedom of the capital market, as well as the stability of money and the banking system show the strongest link. Government size, trade freedom and institutional structures show different relationships depending on the model by which the assessment is made. This is a problem that has been encountered in many studies and raises doubts about the validity of the results. Low levels of market intervention (measured mainly by low taxes and loans) showed a negative but insignificant effect on per capita income, regardless of the assessment method used by the authors - the Autoregressive Distributed Lag (ARDL) model and the method proposed by Johansen (1988). 
Ivana Brkić

Borović $(2014$, a) paid attention to determining the impact of economic freedom on two Balkan countries: Croatia and Bosnia and Herzegovina. The results he obtained are different for the observed countries. While the positive impact of economic freedom on growth was shown in Bosnia and Herzegovina, such an impact is markedly negative in Croatia. The author finds the explanation for such results in the economic crisis that has undoubtedly affected (also) this transition country, but much more in the process of adapting to the new rules, especially with regard to the judicial system that Croatia is facing regarding accession to the European Union. The author explains that it takes some time for the institutional changes to be impregnated into society and expects that economic freedom will then have a positive impact on economic growth. Borović $(2014, b)$ also wanted to examine which of the pillars of economic freedom is determining in terms of the positive impact on economic growth as demonstrated in the previous study. Thus, after eliminating one of the pillars of freedom from the model due to the high correlation, he came to the conclusion that only the pillar of Limited government is positively related to economic growth, while Rule of Law and Market Openness are in a negative relationship. The specificity of the post-war environment, as well as the irregularities in the privatization process, resulted in a high level of corruption and a low level of protection of property rights, which was reflected in the results obtained. The large government involvement in economic and financial flows is also a reason for the negative correlation between Market openness and economic growth. Despite the results, the author advocates reduced government interventions, reduced bureaucracy, and increased rule of law in order to promote economic freedom and, indirectly, economic growth in this country.

Table 10: A tabular presentation of the results of the examinations so far of the situation and changes in the economic freedom of individual countries 
Table 10. Tabular presentation of the results of the examinations so far of the situation and changes of the economic freedom of individual countries

\begin{tabular}{|c|c|c|c|c|c|c|}
\hline $\operatorname{AUTHOR}(\mathbf{S})$ & SAMPLE & $\begin{array}{l}\text { RESEARCH } \\
\text { PERIOD }\end{array}$ & METHOD & $\begin{array}{l}\text { DEPENDENT } \\
\text { VARIABLE }\end{array}$ & INDEPENDENT VARIABLES & EFFECTS \\
\hline Erdal (2004) & Italy & $1960-2000$ & $\begin{array}{l}\text { Ordinary least squares } \\
\text { Granger causality test }\end{array}$ & $\begin{array}{l}\text { Annual real GDP } \\
\text { growth rate }\end{array}$ & \begin{tabular}{l} 
His own index of economic freedom \\
\hdashline Gross fixed capital (\% of GDP) \\
Growth of the working \\
population(15-64 years of age) \\
Growth of number of students \\
enrolled in high school (15-19 years \\
of age)
\end{tabular} & $\begin{array}{l}\text { Positive. } \\
\text { Parts } \\
\text { different. }\end{array}$ \\
\hline \multicolumn{7}{|c|}{ Economic freedom has a positive impact on economic growth. Some aspects affect economic growth differently. Economic freedom causes economic growth. } \\
\hline $\begin{array}{l}\text { Erdal and } \\
\text { Yenipazarli } \\
\quad(2013)\end{array}$ & Turkey & $1970-2006$ & ARDL & $\begin{array}{l}\text { GDP per unit of } \\
\text { work, calculated as } \\
\text { total GDP by total } \\
\text { employees }\end{array}$ & $\begin{array}{l}\begin{array}{l}\text { Their own index of economic } \\
\text { freedom }\end{array} \\
- \text { Primary school enrollment rate } \\
\text { Net capital per unit of labor } \\
\text { Binary variables for the effects of the } \\
\text { financial and economic crisis in } \\
1980,1994,1999 \text { and } 2001 .\end{array}$ & $\begin{array}{l}\text { Positive. } \\
\text { Parts } \\
\text { different. }\end{array}$ \\
\hline \multicolumn{7}{|c|}{$\begin{array}{l}\text { The overall index has a positive and statistically significant impact on economic growth. The stability of money and the banking system, the freedom of trade in the capital market have a } \\
\text { positive and statistically significant impact on economic growth. The impact of other categories of freedom depends on the method used. }\end{array}$} \\
\hline Borović $(2014$, a) & $\begin{array}{l}\text { Croatia and Bosnia } \\
\text { and Herzegovina }\end{array}$ & $2001-2012$ & Ordinary least squares & GDP growth rate & $\begin{array}{c}\text { IEF of the Heritage Foundation } \\
\text { Initial GDP level } \\
\text { Investment (\% of GDP) } \\
\text { Public spending (\% of GDP) } \\
\text { Average investment rate (\%) } \\
\text { Export-import ratio (\% of GDP) }\end{array}$ & $\begin{array}{l}\text { Negative. } \\
\text { Positive. }\end{array}$ \\
\hline \multicolumn{7}{|c|}{ Croatia - negative impact. Bosnia and Herzegovina - positive impact. } \\
\hline Borović $(2014$, b) & $\begin{array}{l}\text { Bosnia and } \\
\text { Herzegovina }\end{array}$ & $2000-2013$ & - & $\begin{array}{l}\text { Average GDP } \\
\text { growth rate }\end{array}$ & $\begin{array}{c}\text { IEF of the Heritage Foundation } \\
\text { Investment (\% of GDP) }\end{array}$ & $\begin{array}{l}\text { Positive. } \\
\text { Parts } \\
\text { different. }\end{array}$ \\
\hline
\end{tabular}

Limited Government is positively related to growth.

Source: Author. 
Ivana Brkić

\section{SECTION SUMMARY}

The first part of the dissertation presents the theoretical background on the relationship between economic freedom and economic growth, which is the basis for subsequently conducted empirical research on a sample of EU Member States.

The first chapter defines the concept of economic freedom and gives a chronological account of the development of economic thought from the aspect of economic freedom. Different currents of opinion were analyzed regarding the optimal level of regulation of the market. In order to accurately determine whether economic institutions are determinants of economic growth, the qualification of economic freedom had to be performed, which reputable organizations have done - measured, monitored and published results in the form of the Economic Freedom Index -. The most famous indices of economic freedom are those constructed by the Freedom House, Scully \& Slottje (1991), the Fraser Institute and the Heritage Foundation, whose indices are briefly presented in the first chapter.

As the empirical part of the dissertation used the data of the Economic Freedom Index of the Heritage Foundation, the second chapter provides a detailed theoretical interpretation of the given index as well as the methodology for calculating the subindices. This was important to present in order to have a clear picture of what the Economic Freedom Index actually encompasses and represents.

The third chapter of the theoretical part was devoted to a review of scientific achievements on the topic of the relation between economic freedom and economic growth. The most important scientific findings on the nature of the relationship between economic freedom as a whole and some of its parts (sub-indices) with economic growth are presented. Also, particular attention within the subchapters was paid to scientific research that examined the relationship between change (as opposed to level) of economic freedom and economic growth. A review of scientific views on the causality in the relationship between economic freedom and economic growth was also conducted, where causality was defined in Granger's sense (Granger, 1969). 
Ivana Brkić

As some authors have established the link between economic, political and civil freedom and economic growth - the most representative studies which have come to some knowledge of the causal links given are presented.

Considering that the subject of the dissertation is the analysis of the impact of (change of) economic freedom on the economy within a specific geopolitical and socio-economic area - the European Union, an analysis of the scientific literature was carried out, which also examined these relations in the same or other groups of countries. Thus the authors, who analyzed the relations between economic freedom and economic growth in groups of countries in the territories of Europe, North and South America, Africa, Asia, among Islamic countries and countries in transition, stood out. Likewise, certain authors focused on specific countries to determine how much economic freedom contributes to the economic prosperity of the countries whose observations are presented in a separate chapter.

As the detailed theoretical basis for empirical research has been made, the second part of the dissertation is fully devoted to the concrete exploration of the impact and causal relationship between economic freedom and economic growth on a sample of EU member states. 


\section{SECTION 2. EMPIRICAL FRAMEWORK}


Ivana Brkić

\section{CHAPTER 3: THE EMPIRICAL RESEARCH METHODOLOGY}

\subsection{INTRODUCTION}

The centerpiece of the dissertation is empirical research aimed at testing the hypotheses based on the results of previous studies on the relationship between economic freedom and growth. In this way, a deductive approach was used in order to attempt to answer the question of whether a panel analysis can determine the existence of a positive link between (change of) economic freedom, its subcomponents and economic growth in the example of European Union countries, as has been proven in most other areas analyzed.

After defining general, specific and individual hypotheses - null and alternative, we describe and create labels of dependent, independent and control variables. Below is presented the method of collecting electronic data as well as their sources, while the method of selection, size and construction of the sample is discussed in detail in the fifth subchapter of this segment. The main statistical procedures are described in the sixth segment of this chapter. A brief description of the descriptive statistical method, correlation analysis and panel analysis as well as the purpose and place of their application within our research are determined here. Particular emphasis was put on panel analysis since it is the main method which was used to try to establish the impact of (change of) economic freedom and its elements on economic growth in the countries of the European Union. The final section summarizes the chapter devoted to setting the methodology for empirical research.

\subsection{DEFINIING HYPOTHESES}

In accordance with the previously set research objectives, the groups of hypotheses listed in the following Tables 15 and 16 are formulated. Table 15 presents null and alternative hypotheses from Group 1, which is dedicated to discovering the impact of economic freedom and its categories on economic growth, while Table 16 presents null and alternative hypotheses examining the impact of the change in the economic freedom index on the economic growth of 
Ivana Brkić

European Union countries. By confirming null hypotheses $\left(\mathrm{H}_{0}\right)$ and thus rejecting the alternative ones $\left(\mathrm{H}_{1}\right)$, the author seeks to establish links between economic freedom and economic growth within the European Union area.

Table 11. General, specific and individual hypotheses of group 1

\section{GENERAL HYPOTHESIS 1}

$\mathrm{H}_{0}$ : Economic freedom has a positive impact on economic growth in EU countries.

$\mathrm{H}_{1}$ : Economic freedom has a negative or no impact on economic growth in EU countries.

\section{SPECIFIC HYPOTHESIS 1}

$\mathrm{H}_{0}$ : Certain aspects of economic freedom have a positive impact on economic growth in EU countries.

$\mathrm{H}_{1}$ : Certain aspects of economic freedom have a negative or no impact on economic growth in EU countries.

\section{INDIVIDUAL HYPOTHESES 1}

1.1. $\mathrm{H}_{0}$ : Property rights have a positive impact on economic growth in EU countries. $\mathrm{H}_{1}$ : Property rights have a negative or no impact on economic growth in EU countries. 1.2. $\mathrm{H}_{0}$ : Government integrity has a positive impact on economic growth in EU countries. $\mathrm{H}_{1}$ : Government integrity has a negative or no impact on economic growth in EU countries. 1.3. $\mathrm{H}_{0}$ : Fiscal freedom has a positive impact on economic growth in EU countries. $\mathrm{H}_{1}$ : Fiscal freedom has a negative or no impact on economic growth in EU countries. 1.4. $\mathrm{H}_{0}$ : Public spending has a positive impact on economic growth in EU countries. $\mathrm{H}_{1}$ : Public spending has a negative or no impact on economic growth in EU countries.

1.5. $\mathrm{H}_{0}$ : Business freedom has a positive impact on economic growth EU countries. $\mathrm{H}_{1}$ : Business freedom has a negative or no impact on economic growth in EU countries.

1.6. $\mathrm{H}_{0}$ : Labor freedom has a positive impact on economic growth EU countries. $\mathrm{H}_{1}$ : Labor freedom has a negative or no impact on economic growth in EU countries. 1.7. $\mathrm{H}_{0}$ : Monetary freedom has a positive impact on economic growth EU countries. $\mathrm{H}_{1}$ : Monetary freedom has a negative or no impact on economic growth in EU countries.

1.8. $\mathrm{H}_{0}$ : Trade freedom has a positive impact on economic growth EU countries. $\mathrm{H}_{1}$ : Trade freedom has a negative or no impact on economic growth in EU countries. 1.9. $\mathrm{H}_{0}$ : Investment freedom has a positive impact on economic growth EU countries. $\mathrm{H}_{1}$ : Investment freedom has a negative or no impact on economic growth in EU countries.

1.10. $\mathrm{H}_{0}$ : Fiscal freedom has a positive impact on economic growth EU countries.

$\mathrm{H}_{1}$ : Fiscal freedom has a negative or no impact on economic growth in EU countries. Source: Author.

Table 12. General and alternative hypothesis 2

\section{GENERAL HYPOTHESIS 2}

$\mathrm{H}_{0}$ : Change of economic freedom has a positive impact on economic growth in EU countries. $\mathrm{H}_{1}$ : Change of economic freedom has a negative or no impact on economic growth in EU countries.

Source: Author. 
Ivana Brkić

\subsection{DEFINING THE RESEARCH VARIABLE}

Within the conducted quantitative analysis in the dissertation, we distinguish between dependent, independent and control variables.

Dependent variable represents Economic growth in the EU countries whose impact factors we seek to examine. Most authors who have conducted and published studies examining the impact of economic freedom on the economies of particular groups of countries have chosen this economic indicator, while some authors have examined the impact of economic freedom on GDP, as well as some other (macro)economic indicators (inequality, productivity, investment, etc.).

Independent variables represent the Index of Economic Freedom formulated by the Heritage Foundation as well as its constituent elements. In order to act methodologically in a proper way, its sub-indices were not included in the analysis of the impact of the overall Index of Economic Freedom on Economic Growth. Consequently, when the impact of the elements of the Economic Freedom Index was examined, the overall index was omitted from the analysis.

Control variables in the analysis were included on the basis of evidence from a number of studies on the impact of different variables on economic growth conducted earlier. Determinants within our model were selected based on the ones used by researchers who conducted similar research on the impact of economic freedom on economic growth, data availability, and the significance of the selected variables.

Table 13 presents all the variables, their symbols that will later be used in the dissertation, as well as the definitions and sources from which the data were taken. 
Table 13. Description and labels of dependent, independent and control variables

\begin{tabular}{|c|c|c|c|c|}
\hline Variable type & Mark & Variable name & Description & Source \\
\hline $\begin{array}{l}\text { Dependent } \\
\text { variable }\end{array}$ & GROWTH & Economic growth & $\begin{array}{l}\text { Annual growth rate of Gross domestic product per capita, expressed in } \\
\% \text { based on the base local currency. } \\
\text { GDP factors are based on the US dollar from } 2010 \text {. GDP per capita is } \\
\text { the gross domestic product divided by population. GDP expressed at } \\
\text { selling price is the sum of value added of all resident producers, which } \\
\text { includes taxes and deducted subsidies that are not already included in } \\
\text { the selling price. Depreciation and the value of degraded and harmed } \\
\text { environment are not deducted from total GDP. }\end{array}$ & World data bank \\
\hline \multirow{9}{*}{$\begin{array}{l}\text { Independent } \\
\text { variables }\end{array}$} & IEF & Economic freedom & $\begin{array}{l}\text { Index of Economic Freedom implies rule of law, government size, } \\
\text { regulatory efficiency and open markets. The index is calculated on the } \\
\text { basis of the unweighted average of ten sub-indices of economic } \\
\text { freedom. }\end{array}$ & $\begin{array}{l}\text { Heritage Foundation/ The } \\
\text { Wall Street Journal }\end{array}$ \\
\hline & F_PROP & Property right & $\begin{array}{l}\text { Property rights subindex measures the ability of individuals to own } \\
\text { private property, which is secured by state laws. }\end{array}$ & $\begin{array}{l}\text { Heritage Foundation/ The } \\
\text { Wall Street Journal }\end{array}$ \\
\hline & F_GINT & Government integrity & $\begin{array}{l}\text { Government integrity subindex assesses the presence of corruption in } \\
\text { the economy, including corruption at the level of the judicial and } \\
\text { administrative systems, as well as among government officials. }\end{array}$ & $\begin{array}{l}\text { Heritage Foundation/ The } \\
\text { Wall Street Journal }\end{array}$ \\
\hline & F_TAX & Tax burden & $\begin{array}{l}\text { The tax burden subindex monitors the fiscal burden of high-tax } \\
\text { economic activities. }\end{array}$ & $\begin{array}{l}\text { Heritage Foundation/ The } \\
\text { Wall Street Journal }\end{array}$ \\
\hline & F_GSPEN & Government spending & $\begin{array}{l}\text { Government spending subindex expresses the level of public spending } \\
\text { relative to GDP. }\end{array}$ & $\begin{array}{l}\text { Heritage Foundation/ The } \\
\text { Wall Street Journal }\end{array}$ \\
\hline & F_BUS & Business freedom & $\begin{array}{l}\text { Business freedom subindex assesses the rights and ability of individuals } \\
\text { to undertake entrepreneurial activities. }\end{array}$ & $\begin{array}{l}\text { Heritage Foundation/ The } \\
\text { Wall Street Journal }\end{array}$ \\
\hline & F_LAB & Labor freedom & $\begin{array}{l}\text { Labor freedom subindex measures the ability of workers and businesses } \\
\text { to carry out activities without restriction by the state. }\end{array}$ & $\begin{array}{l}\text { Heritage Foundation/ The } \\
\text { Wall Street Journal }\end{array}$ \\
\hline & F_MON & Monetary freedom & $\begin{array}{l}\text { Monetary Freedom subindex shows currency stability and market } \\
\text { pricing. }\end{array}$ & $\begin{array}{l}\text { Heritage Foundation/ The } \\
\text { Wall Street Journal }\end{array}$ \\
\hline & F_TRAD & Trade freedom & $\begin{array}{l}\text { Trade freedom subindex monitors the presence of tariff and non-tariff } \\
\text { barriers affecting the international exchange of goods and services. }\end{array}$ & $\begin{array}{l}\text { Heritage Foundation/ The } \\
\text { Wall Street Journal }\end{array}$ \\
\hline
\end{tabular}


The relationship between economic freedom and economic growth in EU countries

Ivana Brkić

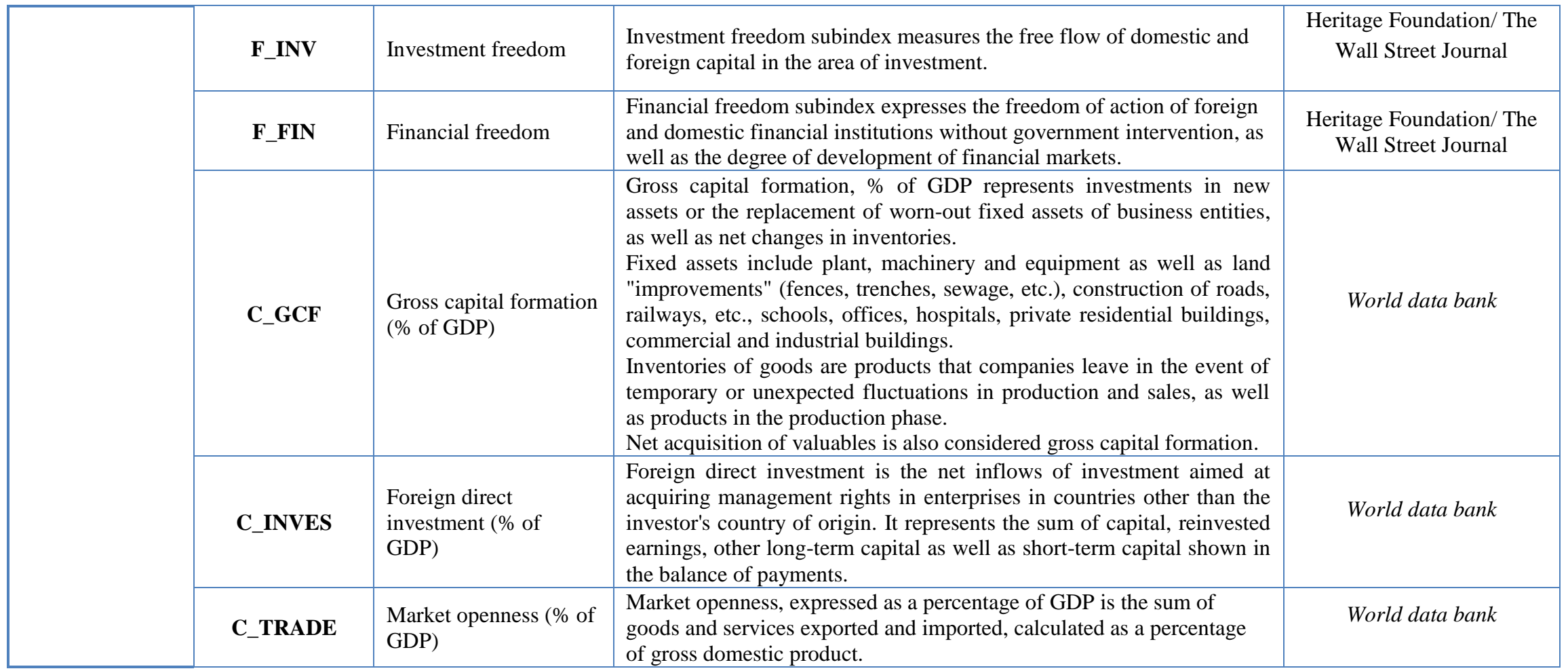

Source: Author. 
Ivana Brkić

\subsection{DATA COLLECTION}

The study is conducted on electronically collected data on the state of economic freedom and economic growth of European Union countries. The aforementioned data on the state of economic freedom were collected on the basis of annual reports published by the Heritage Foundation in collaboration with the Wall Street Journal, while a comprehensive database can be found on their website http://www.heritage.org/index/explore. Collecting data on economic growth as well as other macroeconomic indicators that acted as control variables in the research were taken from the World databank http://data.worldbank.org/.

\subsection{SELECTION METHOD, SIZE AND CONSTRUCTION OF THE SAMPLE}

The study includes the following indicators: The Heritage Foundation Index of Economic Freedom and the annual percentage growth of gross domestic product per capita observed in a sample of EU member states: Austria, Belgium, Bulgaria, Cyprus, Croatia, the Czech Republic, Denmark, Estonia, Finland, France, Germany, Greece, Hungary, Ireland, Italy, Latvia, Lithuania, Luxembourg, Malta, the Netherlands, Poland, Portugal, Romania, Slovakia, Slovenia, Spain, Sweden, and the United Kingdom.

Although not all of these countries were current EU members in each year of observation within the study, their data were included in the analysis because they are currently members of the EU, ie the assumption is that with the very process of preparation for full membership they have already acquired (or were acquiring) the necessary characteristics that would make them equal members of the EU.

Likewise, although the United Kingdom withdrew from the European Union on January 31,2020 , it was part of the EU in the observed period and therefore forms an integral part of the sample. 
Ivana Brkić

The selected group of countries includes countries of different levels of economic development, countries of the former socialist system, countries that are in the transition process, those that have completed this process for better or worse, as well as traditionally capitalist countries. The breadth and variety of the sample is an advantage when performing statistical calculations and enables obtaining statistically significant results. At the same time, all the above countries are gathered and driven by the same goal, members of one of the leading political and economic communities in the world, which is the basis for grouping its (macroeconomic) data for conducting research through panel analysis.

The scientific contribution of selecting this sample is reflected in the absence of studies (available to author) that observed the given group from the aspect of analyzing the impact of economic freedom on economic growth, which may be considered relevant and current given the geopolitical and geo-economic division of the world.

According to the criterion of time span of the observed phenomenon, panel data were used with which at different time intervals the same phenomenon was observed - the state of economic freedom based on the Heritage Foundation Index of Economic Freedom as well as economic growth, presented by the percentage annual increase of GDP per capita for the observed EU member states, as well as other traditional macroeconomic indicators acting as control variables. These phenomena were covered from 1994 to 2018, that is, a total of 25 years, which is considered to be an appropriate sample size necessary for conducting panel analysis for the purpose of obtaining relevant and reliable results.

It should be noted that every year the Heritage Foundation publishes a report on the state of economic freedom in the world, constructed on the basis of data from the second half of the year before last to the middle of the previous year. So, for example 2019 Index covers the second half of 2017 through the first half of 2018 and the like. Accordingly, the data from the report of the current year were related to the percentage growth of GDP per capita from the previous year, explaining that the state of economic freedom reflected on the economic growth in that year. For example, data on the state of economic freedom from the 2019 report (which actually refer to the 
Ivana Brkić

state of economic freedom from the second half of 2017 to mid-2018) were compared with the data on the percentage growth of GDP per capita of 2018.

\subsection{STATISTICAL PROCEDURE}

For the purpose of testing the defined hypotheses, based on the formulated goals and within the subject of the research, a methodological approach was constructed, which formed the framework for conducting the empirical part of the research within the dissertation.

The following statistical methods and techniques were applied in the empirical research:

Descriptive statistical methods - for calculating, displaying and describing the basic characteristics of statistical series;

$>$ Correlation analysis - to determine whether there is a link between (change of) economic freedom, its elements and the percentage growth of GDP per capita in EU countries;

> Panel analysis - to determine the impact of economic freedom and its elements, as well as the impact of the change in the Index of Economic Freedom on the percentage growth of GDP per capita in EU countries;

As the decisive method for determining the impact of economic freedom on economic growth in the EU countries used in the research within the dissertation is panel method, we provide below a concise overview of its basic characteristics.

As regards causal inference, fixed-effects (FE) regression method proved to be particularly useful (Gangl, 2010). Standard regression models yield biased estimates of causal effects if there are unobserved confounders whereas FE regression can (provided certain assumptions are valid) yield unbiased estimates. FE regression has become a default method for estimating causal effects from panel data. However, it can be applied with any kind of multi-level data. FE models identify the causal effect under weaker assumptions which is why they are used by social researchers undertaking causal analysis. It has been argued that panel data are particularly 
Ivana Brkić

beneficial for using FE models since, due to their richness, they make it possible to investigate numerous important social science questions.

Estimation of FE is based on the error components model:

$$
y_{\text {it }}=x_{i t} \beta+\alpha_{i}+\varepsilon_{\text {it }}
$$

$y_{i t}$ represents the observed outcome of person $i$ at time $t, \mathbf{x}_{i t}$ is the $(1 \mathrm{x} K)$ vector of covariates of the person measured during the same period of time, and $\beta$ is the corresponding $(K \times 1)$ vector of parameters that need to be estimated. The error term of this model is dividied into two components. The $\alpha_{i}$ are stable person-specific characteristics that are rarely observed by the researcher (e.g. cognitive ability, genetic disposition, personality) and frequently associated with the covariates. Therefore, the $\alpha_{i}$ are unobserved effects capturing time-constant individual heterogeneity. The second component $\varepsilon_{i t}$ is an idiosyncratic error that varies across subjects and over time.

According to (Best \& Wolf, 2015), the easiest way to estimate the parameters of the model is by pooling the data and running ordinary least squares (pooled OLS, POLS). Consistency of POLS requires exogeneity of time-constant individual heterogeneity and idiosyncratic errors. POLS estimation does not distinguish between the two error components, which are replaced by the composite error

$$
v_{i t}=\alpha_{i}+\varepsilon_{i t}
$$

The key assumption for consistency of the FE estimator is the strict exogeneity condition imposed due to the idiosyncratic errors. This excludes not only simultaneous correlation of regressors and the idiosyncratic errors, but also correlation of past and future values of covariates and errors. This is the reason why the assumption is termed 'strict' exogeneity. Apparently, this assumption is stronger to some degree than the contemporaneous exogeneity assumption required for POLS. The key advantage, however, of the FE framework is that no assumption is needed regarding the relationship between stable characteristics and regressors. Therefore, FE estimation applies POLS to transformed data where the transformation (called 'demeaning' or 'within transformation') extracts the variation within subjects over time, but discards variation 
Ivana Brkić

across units. The conventional FE estimator is the POLS estimator applied to these demeaned data. As mentioned above and shown in the statistical framework section below, the strict exogeneity assumption is sufficient for consistency of the FE estimator. Hence, with panel data and the FE estimator, a causal effect can be identified under weaker assumptions (compared to cross-sectional OLS or POLS).

Another class of panel estimators is based on the random-effects (RE) model. The conventional RE model starts from the error components model given in (9). RE requires the same strict exogeneity assumption as FE. However, as regards POLS, the assumption about stable unobserved characteristics is required. The orthogonality condition $E\left(\alpha_{i} \mid \mathrm{x}_{i}\right)=E\left(\alpha_{i}\right)=0$ indicates that stable unobserved confounders may not be related to any of the regressors. Due to the fact that this assumption is so restrictive, RE often fails to identify the causal effect of interest. Provided both conditions hold and the conditional mean is modeled properly, the RE estimator is consistent because $E\left(v_{i t} \mid x_{i t}\right)=0$. This model can be written as follows:

$$
y_{i}=x_{i} \beta+v_{i}
$$

where $v_{\mathrm{i}}=\alpha_{i} \mathrm{j}_{\mathrm{T}}+\varepsilon_{i}$ and $\mathrm{j}_{\mathrm{T}}$ is a ( $\left.\mathrm{T} \mathrm{\textrm {x }} 1\right)$ vector of ones

RE has an advantage over POLS in terms of greater efficiency at the price of a stronger exogeneity assumption. The advantage of RE over FE is also greater efficiency given the orthogonality condition holds. Provided that it does not hold, RE is inconsistent and priority should be given to FE.

Descriptive statistical and panel analysis were carried out using the statistical program "R", with the help of which a graphical presentation of the obtained results was made.

The results obtained from empirical research are presented in tables and graphs for the purpose of reviewing the research results, which will then be analyzed in relation to the set hypotheses, in order to draw appropriate conclusions. 
Ivana Brkić

\subsection{CHAPTER SUMMARY}

This chapter explicates the methods of empirical research. In this regard, general, specific and individual hypotheses were defined first. After that, dependent, independent, and control variables were described and finally methods of collection and sources of the variables were presented. The construction, size and selection of the sample were dealt with in detail the fifth subchapter, and the sixth section provided an overview of the statistical methods conducted in the empirical research, with particular attention to panel analysis, as crucial for determining the relationships or impact of (change of) economic freedom and its elements on economic growth in EU countries.

The next chapter is devoted to the analysis of electronically collected data, which were processed with the help of the mentioned statistical methods (descriptive, correlation and panel) in order to test the set hypotheses and make conclusions regarding the subject of the research. 
Ivana Brkić

\section{CHAPTER 4: RESULTS OF THE EMPIRICAL RESEARCH}

\subsection{INTRODUCTION}

This chapter presents the results obtained by statistical analysis over panel data. In the second, third and fourth subchapters a panel analysis of the impact of economic freedom, its elements and change of economic freedom on economic growth was conducted in EU countries, covering a period of twenty-five years. First, descriptive analysis and "familiarization" with the variables (dependent, independent and control) were carried out through mean values, standard deviations, minimum and maximum, while heterogeneity across countries and years was presented graphically. The graph also shows the relationship between the independent and dependent variable in each country. This was followed by determining the correlation between dependent and independent variables for each country, on the basis of which the nature of the relationship as well as its statistical significance can be established. Tests were performed that determined the type of panel analysis that is appropriate for conducting given our data. Subsequent tests were also performed in order to validate the data or adjust our data in order to implement the Fixed-Effects (FE) model: cross-sectional dependence, autocorrelation, stationarity, heteroskedasticity. Finally, panel models were presented and the impact of the independent (and control) variables on the dependent variable in fixed-effects regressions was determined. 
Ivana Brkić

\subsection{RESULTS OF THE PANEL ANALYSIS ON THE IMPACT OF ECONOMIC FREEDOM ON ECONOMIC GROWTH IN THE EU COUNTRIES}

Panel data (longitudinal data or cross-sectional time-series data) in this research includes $\mathrm{T}=25$ (time period) and $\mathrm{n}=28$ (individuals). Here, the same individuals (countries) are observed for each period, therefore we had a fixed panel (Greene, 2008).

The panel data was balanced, but with some missing values. The issue of missing values was solved by employing EMB (expectation-maximization with bootstrapping) algorithm (Honaker, King \& Blackwell, 2011).

Table 14 describes the basic characteristics of the dependent, independent and control variables by descriptive statistics.

Table 14. Descriptive statistics of dependent, independent, and control variables

\begin{tabular}{|l|c|c|}
\hline \multicolumn{1}{|c|}{ Variable } & Mean & Standard deviation \\
\hline GROWTH & 2.55 & 3.47 \\
\hline EFI & 67.09 & 7.16 \\
\hline C_GCF & 22.89 & 4.45 \\
\hline C_INVES & 8.98 & 31.23 \\
\hline C_TRADE & 110.01 & 62.32 \\
\hline
\end{tabular}

Source: Author.

The dependent variable Growth has max of 23.94 and min value of -14.56 . Mean values and standard deviation of dependent variable are 2.55 and 3.47.

In the next graph no 1 we will take a closer look in order to see how the average level of Growth has changed over time for each country.

Economic growth in the EU countries recorded slight fluctuations in the last quarter of the century, with the most dramatic decline caused by the global economic crisis that began in 2008, having the most significant effects in 2009, which can be clearly seen in Graph 1 . 
Graph 1. Changes in Growth per country (1994 - 2018)

\section{Changes in Growth per country (1994-2018)}

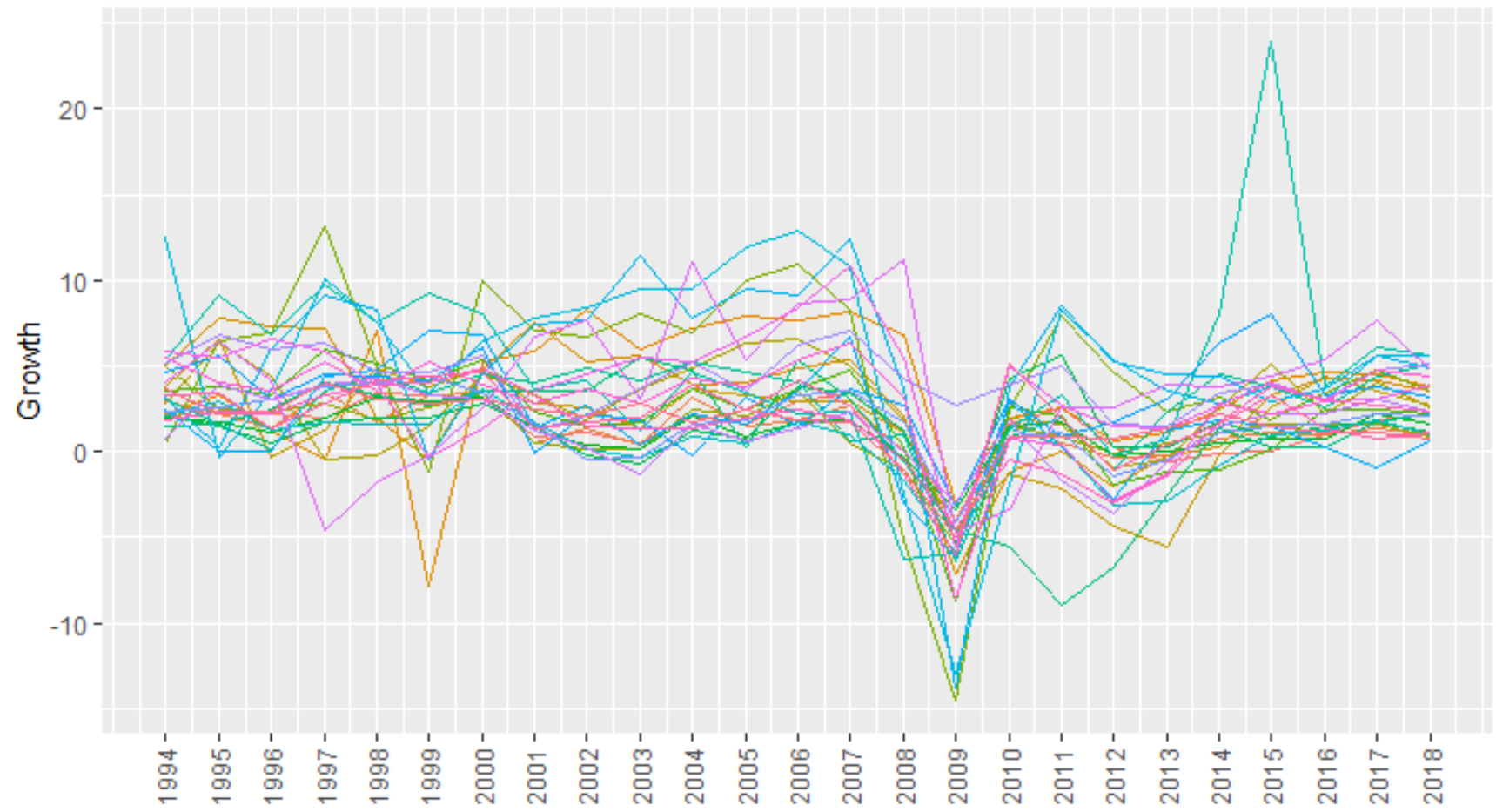

$$
\begin{array}{ll}
\text { Country } & \\
\text { - Austria } & - \text { Italy } \\
\text { - Belgium } & - \text { Latvia } \\
\text { - Bulgaria } & - \text { Lithuania } \\
\text { - Croatia } & - \text { Luxembourg } \\
\text { - Cyprus } & - \text { Malta } \\
\text { - Czech Republic } & - \text { Netherlands } \\
\text { - Denmark } & - \text { Poland } \\
\text { - Estonia } & - \text { Portugal } \\
\text { - Finland } & - \text { Romania } \\
\text { - France } & - \text { Slovak Republic } \\
\text { - Germany } & - \text { Slovenia } \\
\text { - Greece } & - \text { Spain } \\
\text { - Hungary } & - \text { Sweden } \\
\text { - Ireland } & - \text { United Kingdom }
\end{array}
$$

Source: Author.

From the picture above we can see that in 2015 Ireland had the highest growth (23.94), followed by Estonia 1997 (13.08), Latvia 2006 (12.92) and Lithuania 2007 (12.41). Estonia had the lowest growth in 2009 (-15.56) followed by Lithuania 2009 (-13.86), Latvia (12.97), Greece 2011 (-8.99) and Finland 2009 (-8.71).

Therefore, we can conclude that in 2009 most countries had a negative growth with the exception of Poland which achieved a positive growth in 2015 (2.75). The highest growth was achieved in 2015 (Ireland - 23.94). In the same year, Austria had the lowest growth (0.02). 
Ivana Brkić

In the next graphs 2 and 3, heterogeneity across countries and years are presented.

Graph 2. Heterogeneity in economic growth across years in selected sample

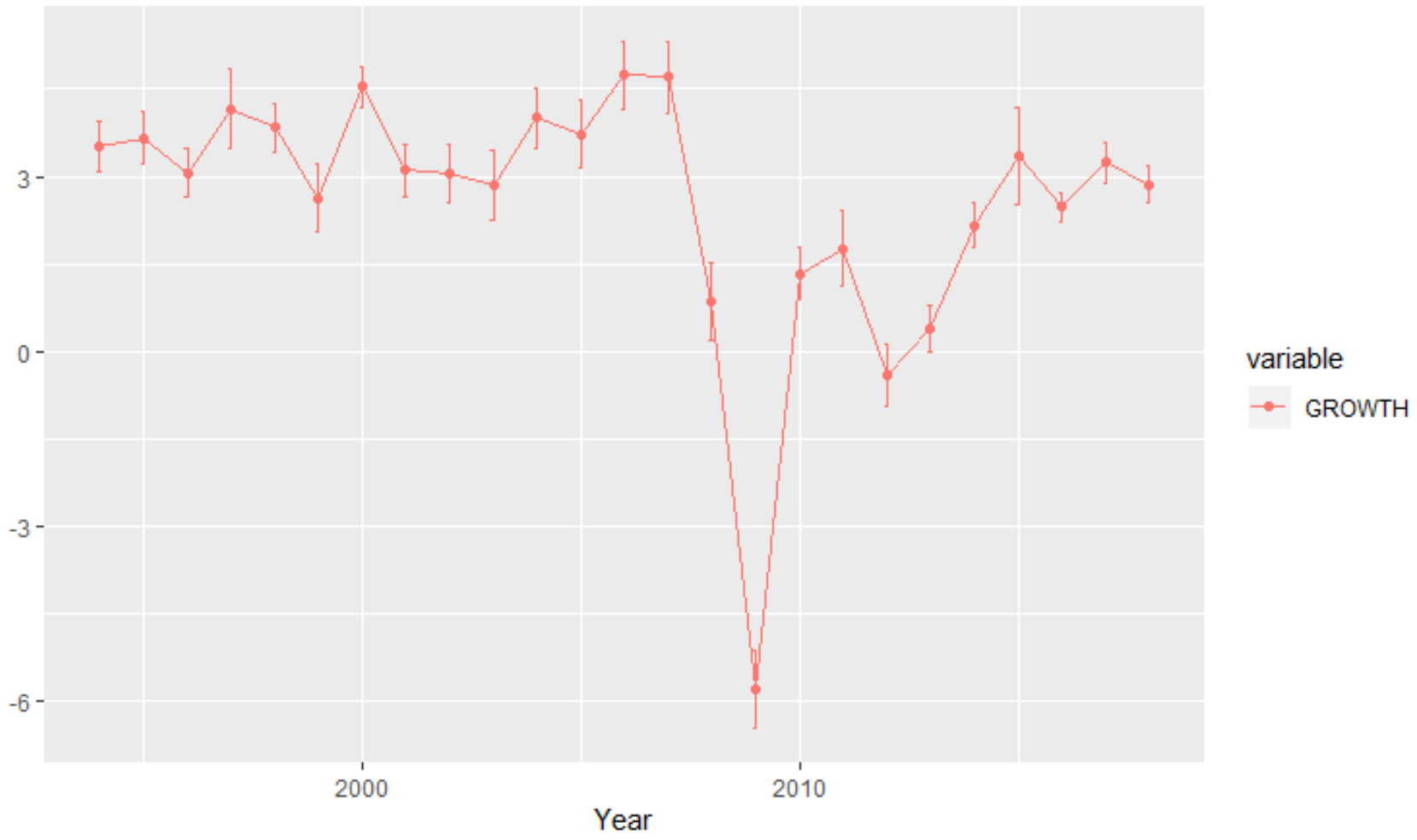

Source: Author.

From the graph above we can see a drastic change of the dependent variable in 2009 so the mean values of dependent variable across countries are in range from 0.5 to 4.5 .

Graph 3. Heterogeneity in economic growth across countries in the selected sample

\section{Heterogeineity across countries}

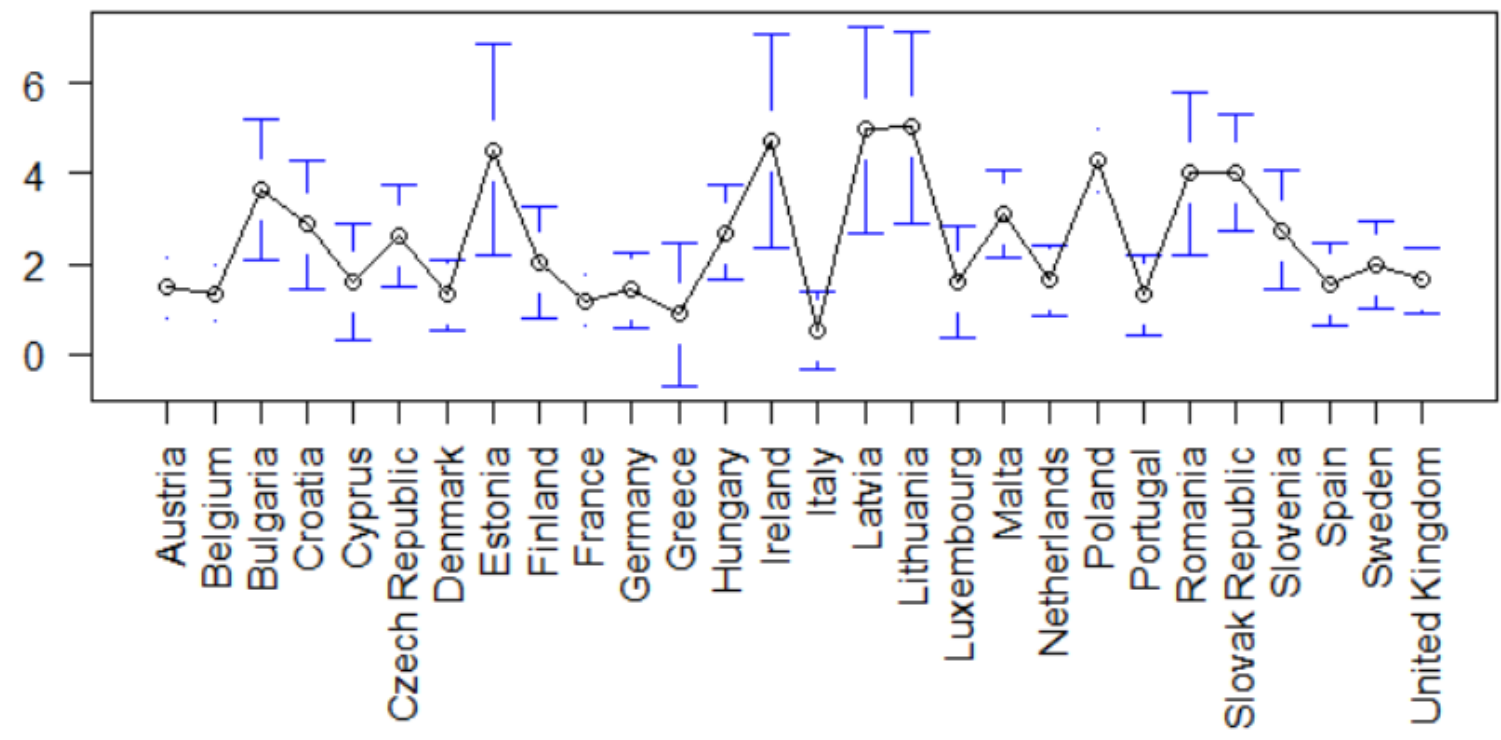


The above graph presents the within-country variances. Within-subject variation refers to the variation seen in a group of subjects which are all treated the same way. Between-subject variation is the difference between different groups exposed to different factors. In panel data, fixed effects estimator (within estimator) is used to refer to an estimator for the coefficients in the regression model. In panel data, random effects model is used when one assumes no fixed effects. The random effects model is a special case of the fixed effects model. The picture below presents a visualization of the scatterplots between Growth and EFI by countries. 
Graph 4. Relationship between independent and dependent variable in each country

\section{Relationship Between Growth and EFI}

By countries (1994-2018)
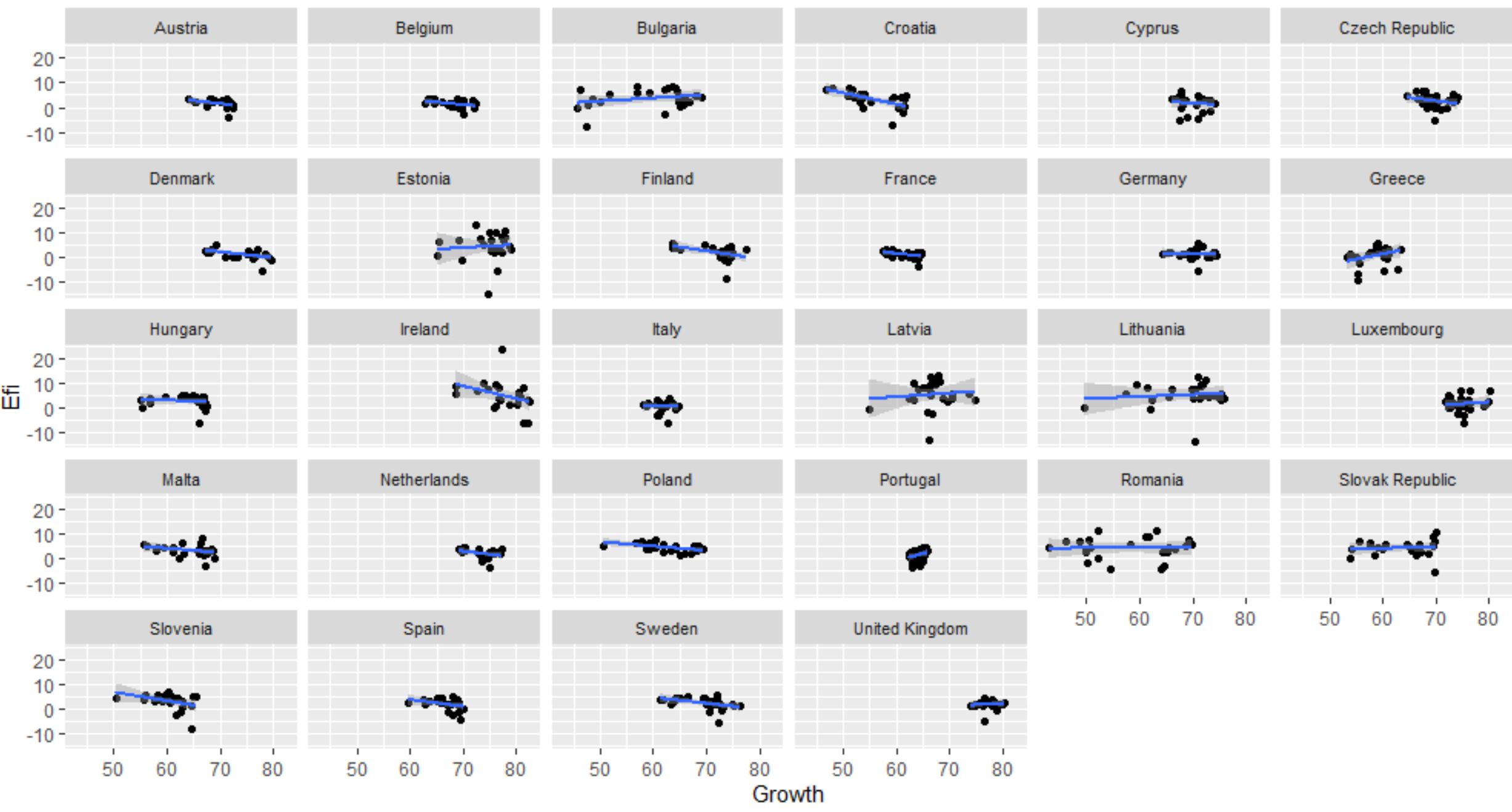

Source: Author. 
Ivana Brkić

The graphs below (graphs 5-8) present the correlation between dependent and independent variables for each country.

Graph 5. Correlation between Index of economic freedom and Economic growth for each country

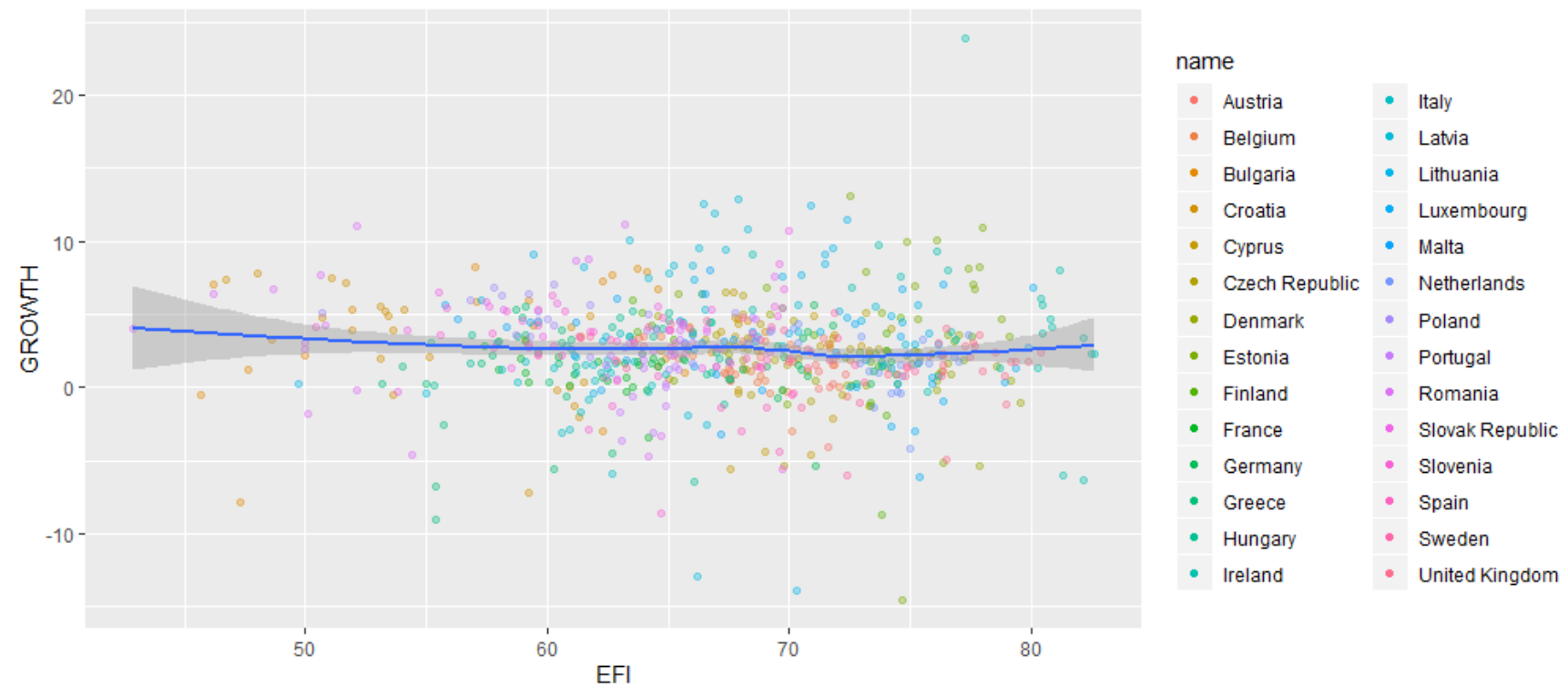

Source: Author.

We can see that the association between Index of economic freedom and Economic growth is slightly negative and not statistically significant.

Graph 6. Correlation between control variable Gross capital formation (\% of GDP) and dependent variable Economic growth

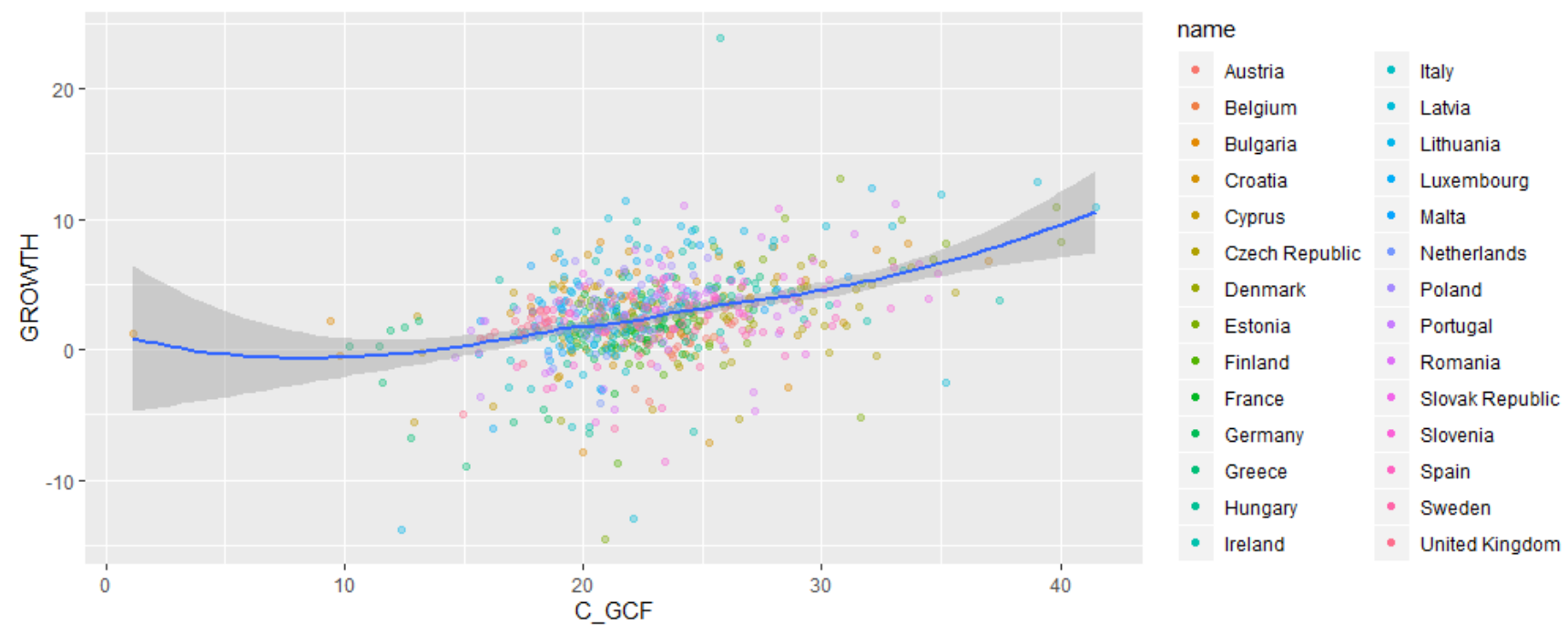

Source: Author.

We can notice that the association is positive and statistically significant $(\mathrm{p}<0.001)$. 
Ivana Brkić

Next, we sought to examine the correlation between control variable Foreign direct investment, net inflows (\% of GDP) and dependent variable GDP per capita growth (annual $\%)$ and we can conclude there is no linear association (Graph 7).

Graph 7. Correlation between Foreign direct investment, net inflows (\% of GDP) and GDP per capita growth (annual \%)

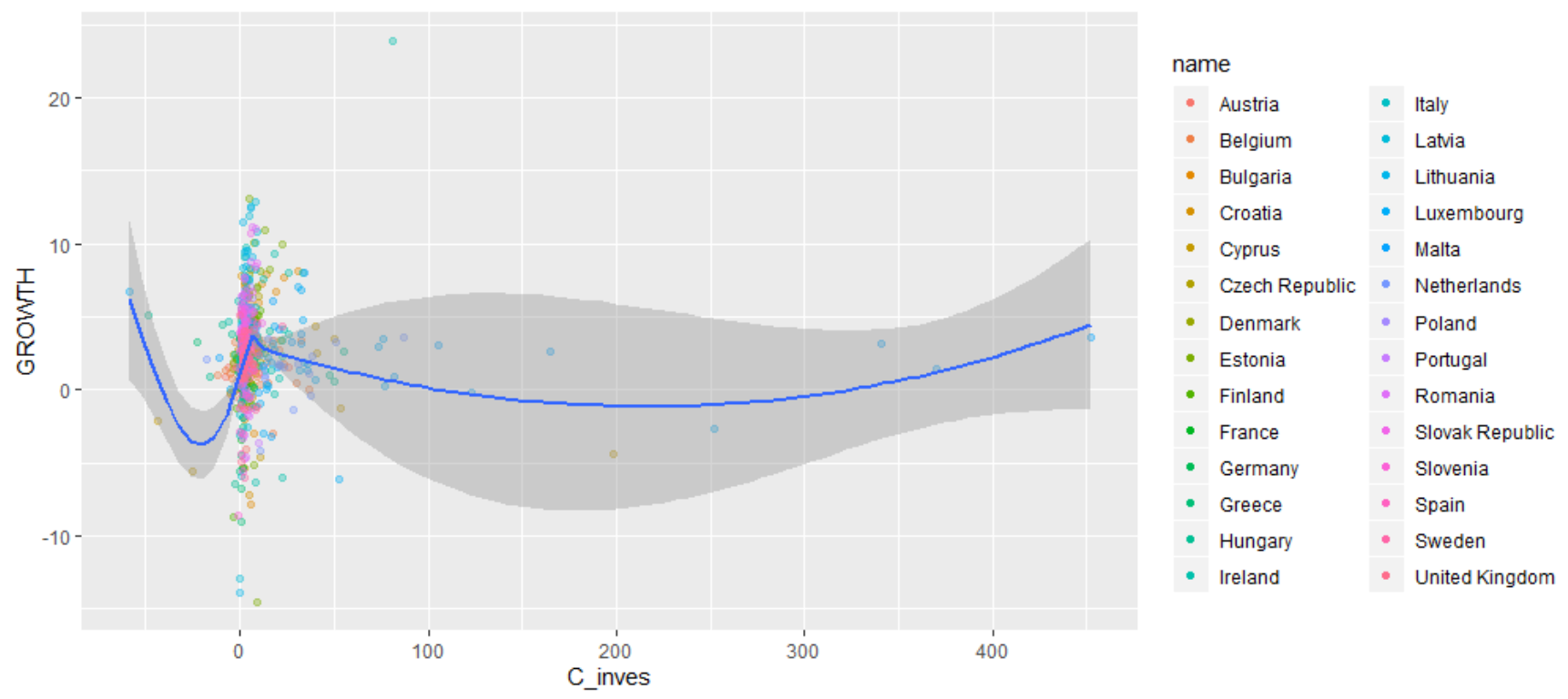

Source: Author.

The (next) graph 8 presents the correlation between control variable Trade (\% of GDP) and dependent variable Economic growth in the observed sample. This is a very mild type of Preston curve (Preston, 1975). While the association does not look linear, it still is statistically significant $(\mathrm{p}=0.049)$.

Graph 8. Correlation between Trade (\% of GDP) and GDP per capita growth (annual \%)

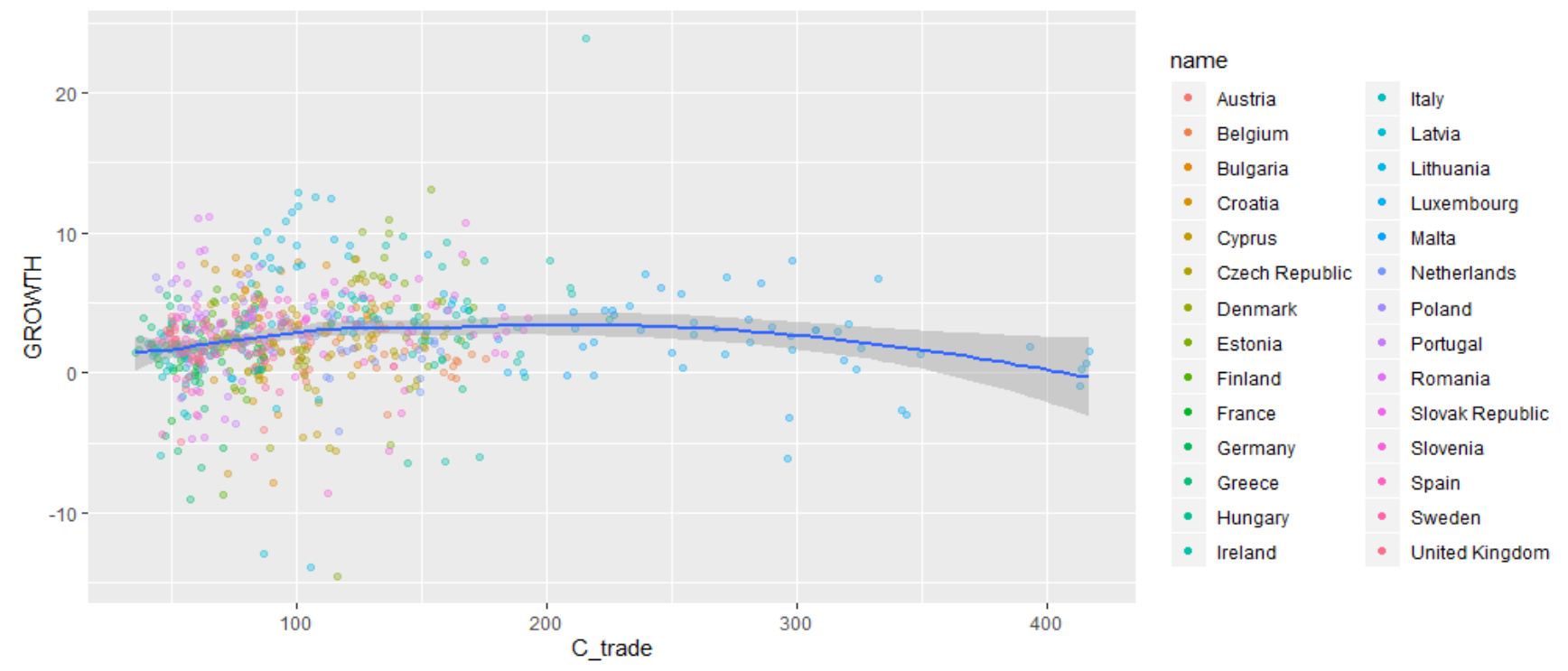

Source: Author. 
Ivana Brkić

In Figure 1 and Table 15 correlation between variables of this panel data is presented. Apparently, there is no strong correlation between variables. We detected significant correlation between Growth and C_inves $(\mathrm{r}=0.17, \mathrm{p}<0.001)$, Growth and Efi $(\mathrm{r}=-0.12$, $\mathrm{p}=0.001)$, Growth and C_trade $(\mathrm{r}=-0.16, \mathrm{p}<0.001)$, Growth and C_GCF $(\mathrm{r}=0.37, \mathrm{p}<0.001)$, EFI and C_inves $(r=0.24, p<0.001)$, Efi and C_trade $(r=0.39, p<0.001)$, C_GCF and C_inves $(\mathrm{r}=0.13, \mathrm{p}<0.001), \mathrm{C} \_\mathrm{GCF}$ and C_trade $(\mathrm{r}=0.13, \mathrm{p}<0.001)$ and between $\mathrm{C}$ _inves and C_Trade $(\mathrm{r}=0.36, \mathrm{p}<0.001)$.

Figure 1. Correlation between variables of panel data

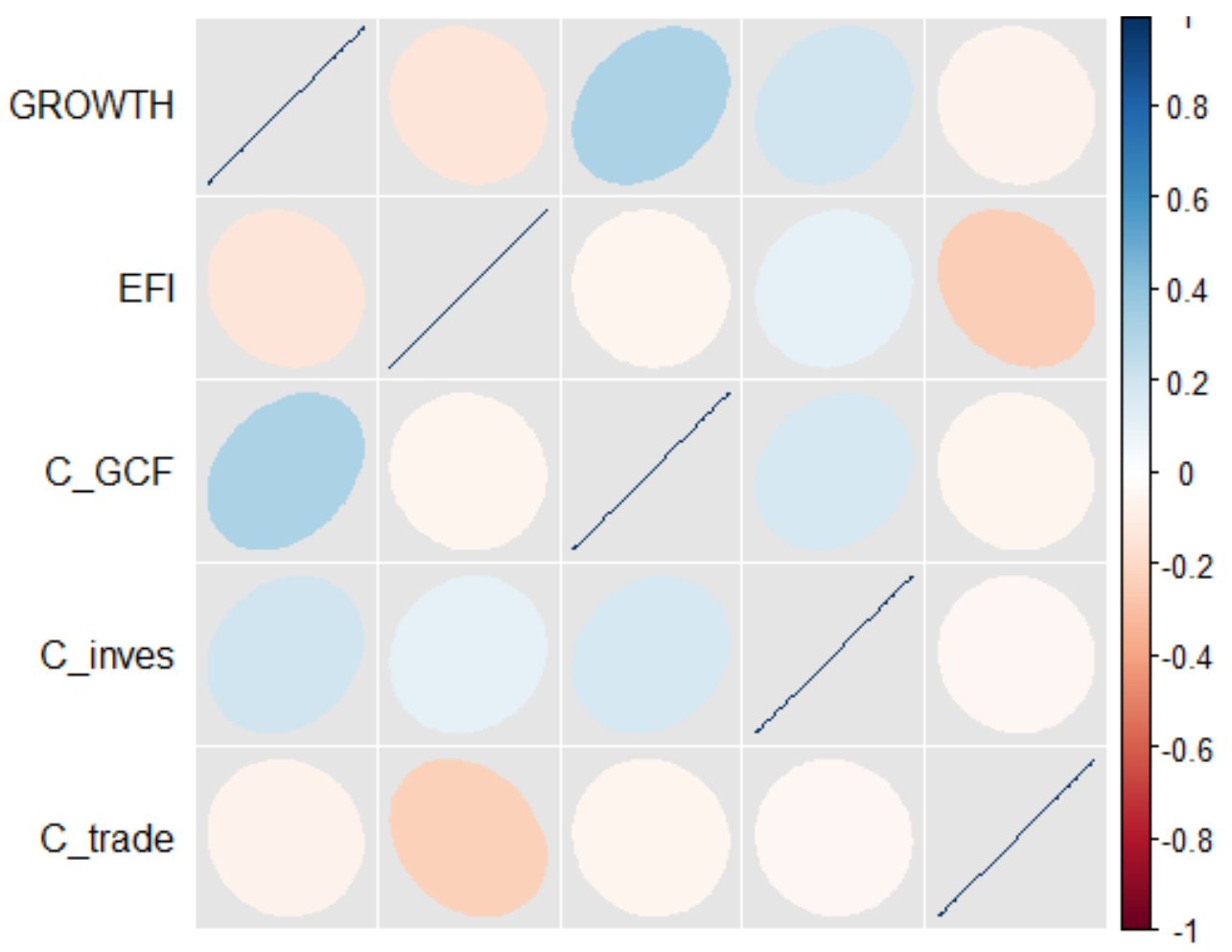

Source: Author.

Table 15. Correlation between variables of panel data

\begin{tabular}{|l|r|r|r|r|r|}
\hline \multicolumn{1}{|c|}{ r } & GROWTH & EFI & C_GCF & C_inves & C_trade \\
\hline GROWTH & 1 & -0.06908 & 0.392047 & 0.000549 & 0.077037 \\
\hline EFI & -0.1201 & 1 & 0.053324 & 0.085985 & 0.33281 \\
\hline C_GCF & 0.365831 & -0.03218 & 1 & -0.04097 & 0.015072 \\
\hline C_inves & 0.172403 & 0.240793 & 0.131556 & 1 & 0.359274 \\
\hline C_trade & 0.159992 & 0.388565 & 0.127574 & 0.408037 & 1 \\
\hline \multicolumn{1}{c|}{ p } & GROWTH & EFI & C_GCF & C_inves & C_trade \\
\hline GROWTH & 1 & 0.067777 & $<0.001$ & 0.988607 & 0.042181 \\
\hline EFI & 0.001455 & 1 & 0.159948 & 0.025161 & $<0.001$ \\
\hline C_GCF & $<0.001$ & 0.396581 & 1 & 0.287068 & 0.69142 \\
\hline C_inves & $<0.001$ & $<0.001$ & 0.0006 & 1 & $<0.001$ \\
\hline C_trade & $<0.001$ & $<0.001$ & 0.000742 & $<0.001$ & 1 \\
\hline
\end{tabular}

Source: Author. 
Multicolinearity between independent variables was not detected $(\mathrm{VIF}(\mathrm{Efi})=1.13$; $\operatorname{VIF}\left(C \_G C F\right)=1.01 ; \operatorname{VIF}(C$ _inves $)=1.16$ and $\operatorname{VIF}\left(C \_\right.$trade $\left.)=1.27\right)$.

Finally, let us see what it looks like when we plot dependent variable over time (Graph 9). This looks like a stable common time trend for most countries.

Graph 9. Plot of the dependent variable GDP per capita growth (annual \%) over time for the selected sample

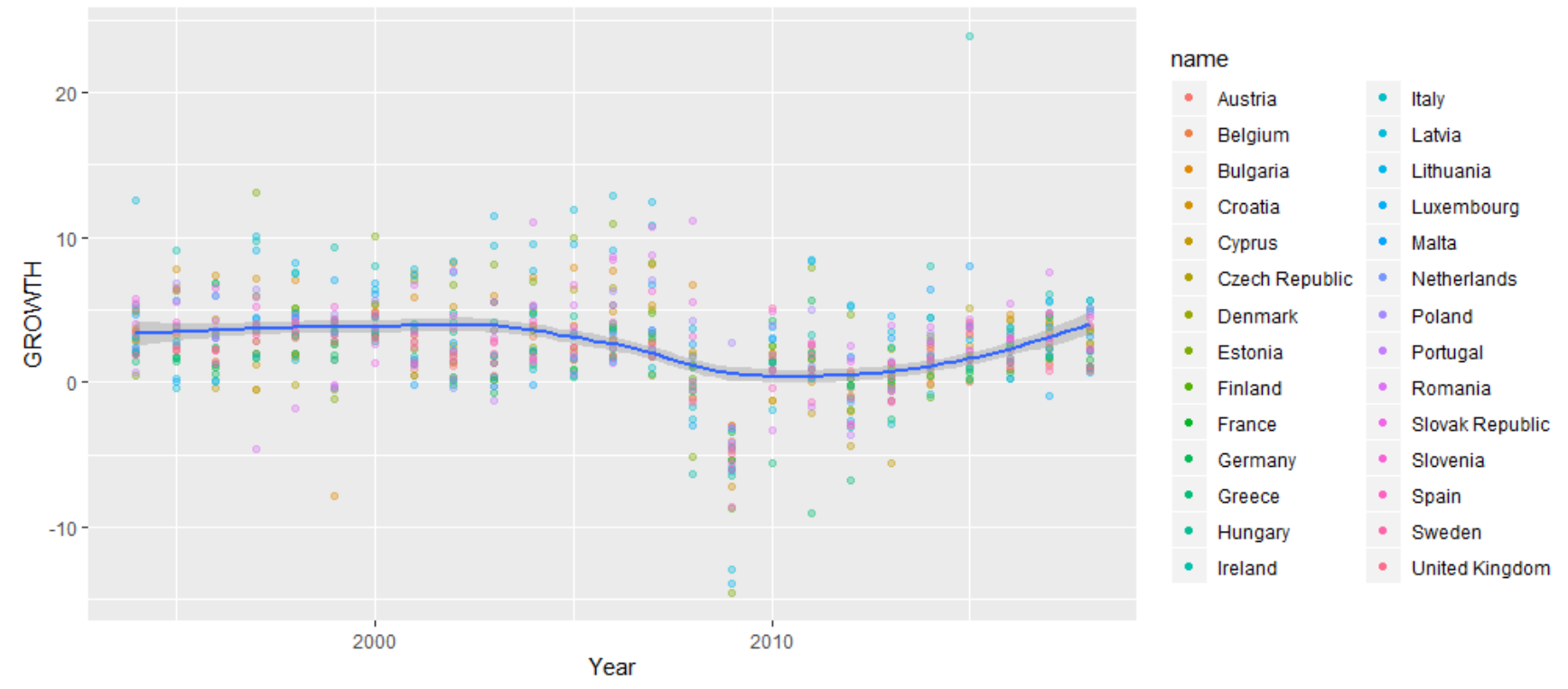

Source: Author.

In the next segment, we conduct a panel analysis, more precisely the Fixed Effects model. With this model we are controlling for the average differences across countries in any unobservable predictors. The fixed effects model discards the between-variation and infers the causal effect from the within-variation (Best \& Wolf, 2015). We started with fixed effects model where effect was one-way and accorded to individuals i.e. countries and did not include time effects. The results are presented in the Table 16.

Table 16. Fixed effects model - the impact of economic freedom on economic growth in European Union countries

\begin{tabular}{|l|l|l|l|l|}
\multicolumn{1}{|c|}{ Variable } & \multicolumn{1}{c|}{ Estimate } & \multicolumn{1}{c|}{ SE } & \multicolumn{1}{c|}{ t value } & \multicolumn{1}{c|}{$\mathrm{p}$} \\
\hline EFI & -0.196 & 0.033 & -5.89 & $<0.001$ \\
\hline C GCF & 0.37 & 0.032 & 11.61 & $<0.001$ \\
\hline C inves & 0.0006 & 0.004 & 0.141 & 0.888 \\
\hline C trade & 0.026 & 0.006 & 3.956 & $<0.001$ \\
\hline F-statistic: 36.3 on 4 and 645 DF, p-value: $<0.001$ & $\mathrm{R}^{2}: 28.4 \%$ & Adjusted $\mathrm{R}^{2}: 24.4$ \\
\hline
\end{tabular}

Source: Author. 
The results obtained from the model with random effects are presented in Table 17.

Table 17. Random effects model - the impact of economic freedom on economic growth in European Union countries

\begin{tabular}{|l|l|l|l|l|}
\hline \multicolumn{1}{|c|}{ Variable } & \multicolumn{1}{c|}{ Estimate } & \multicolumn{1}{c|}{ SE } & \multicolumn{1}{c|}{ t value } & \multicolumn{1}{c|}{$\mathrm{p}$} \\
\hline EFI & -0.119 & 0.02 & -4.59 & $<0.001$ \\
\hline C GCF & 0.34 & 0.03 & 11.31 & $<0.001$ \\
\hline C inves & 0.0007 & 0.004 & -0.198 & 0.843 \\
\hline C trade & 0.011 & 0.003 & 2.813 & 0.004 \\
\hline F-statistic: 136.72 on 4 DF, p-value: $<0.0001$ & $\mathrm{R}^{2}: 26.9 \%$ & Adjusted $\mathrm{R}^{2}: 26.4 \%$ \\
\hline
\end{tabular}

Source: Author.

We used the Hausman test (or the test for endogeneity) to test whether the unique errors are correlated with the regressor. The results of comparing the fixed model with the random model are the following:

chisq $=14.41, \mathrm{df}=4, \mathrm{p}$-value $=0.0061$. The result indicates that we need to use fixed effect model for our data.

Assumptions:

1. We tested cross-sectional dependence using the test Breusch-Pagan LM of independence (Breusch \& Pagan, 1979, Hoechle, 2007). The null hypothesis in the B$\mathrm{P} / \mathrm{LM}$ test of independence is that residuals across entities are not correlated. B-P/LM and Pasaran CD (cross-sectional dependence) tests are used to test whether the residuals are correlated across entities. Result was shown chisq $=2336.8, \mathrm{df}=378, \mathrm{p}$ $<0.01$, so we can conclude that our model has cross-sectional dependence.

2. We tested serial correlation (autocorrelation) using the Breusch-Godfrey test. The null hypothesis of this test is that there is not serial correlation. Results was shown chisq $=$ $157.59, \mathrm{df}=16, \mathrm{p}<0.01$. According to the result, there is a serial correlation.

3. We tested stationarity using the Dickey-Fuller test. The hull hypothesis of this test is that the series is nonstationary. The result was shown for dependent variable Growth: Dickey-Fuller $=-10.826, p=0.01$. According to the result, there are no unit roots present. For independent variables: EFI : Dickey-Fuller $=-5.3599$, Lag order $=2$, pvalue $=0.01$, C_GCF: Dickey-Fuller $=-3.25$, Lag order $=2, \mathrm{p}$-value $=0.025$, C_inves: Dickey-Fuller $=-10.159$, Lag order $=2$, p-value $=0.01$ and C_trade: Dickey-Fuller $=-3.8492$, Lag order $=2$, p-value $=0.01654$. According to the result, 
there are no unit roots present in independent variables.

4. We tested heteroskedasticity using the Breusch-Pagan test. The null hypothesis of this test is that there is homoskedasticity. The result was shown $\mathrm{BP}=9.343$, df $=4$, $\mathrm{p}=0.054$. According to the result, there is no heteroskedasticity.

The problem with cross-sectional dependence we solved by including time effects in our model. We tested statistical difference between fixed effects model without time effects and with time effects by $F$ test for individual effects and obtained the next results $F=19.362$, df1 $=24, \mathrm{df} 2=621, \mathrm{p}<0.01$. According to these results, we can conclude that it is better to use time-fixed effects.

The problem of heteroskedasticity was solved by using the robust covariance matrix estimator HAC (Andrews, 1991).

The results of our model with above improving are presented in Table 18.

Table 18. Final fixed effects model - the impact of economic freedom on economic growth in European Union countries

\begin{tabular}{|l|l|l|l|l|}
\multicolumn{1}{|c|}{ Variable } & \multicolumn{1}{c|}{ Estimate } & \multicolumn{1}{c|}{ SE } & \multicolumn{1}{c|}{ t value } & \multicolumn{1}{c|}{$\mathrm{p}$} \\
\hline EFI & 0.04 & 0.043 & -0.89 & 0.37 \\
\hline C GCF & 0.252 & 0.042 & 5.92 & $<0.001$ \\
\hline C inves & 0.001 & 0.003 & -1.14 & 0.885 \\
\hline C trade & 0.031 & 0.012 & 2.65 & 0.008 \\
\hline F-statistic: 25.115 on 4 and 621 DF, -value: 0.0001 & $\mathrm{R}^{2}: 35.4 \%$ & Adjusted $\mathrm{R}^{2}: 36.9 \%$ \\
\hline
\end{tabular}

Source: Author.

These are the results of the model with fixed group and time effect. This is known as a "fixed effects" regression because it holds constant (fixes) the average effects of each country. Statistically significant independent variable is C GCF $(\mathrm{p}<0.001)$ and independent variable C trade $(\mathrm{p}=0.091)$. It means that each 1 unit increase of C GCF cause increases Growth by 0.252 and also each 1 unit increase of $\mathrm{C}$ trade cause increases Growth by 0.031 . 


\subsection{RESULTS OF THE PANEL ANALYSIS ON THE IMPACT OF ELEMENTS OF ECONOMIC FREEDOM ON ECONOMIC GROWTH IN THE EU COUNTRIES}

The descriptive statistics of the dependent, independent and control variables are presented in Table 19.

Table 19. Descriptive statistics of the dependent, independent and control variables

\begin{tabular}{|l|r|r|r|r|r|}
\hline Variables & \multicolumn{1}{|c|}{ N } & \multicolumn{1}{c|}{ Mean } & Std. dev. & \multicolumn{1}{c|}{ Min. } & \multicolumn{1}{c|}{ Max. } \\
\hline GROWTH & 700 & 2.542169 & 3.442712 & -14.5599 & 23.94065 \\
\hline C_gcf & 696 & 22.89818 & 4.44977 & 1.167136 & 41.44911 \\
\hline C_inves & 678 & 8.854861 & 31.60209 & -58.3229 & 451.7155 \\
\hline C_trade & 696 & 110.157 & 62.45287 & 36.16312 & 416.3892 \\
\hline F_PROP & 690 & 70.78551 & 18.38703 & 30 & 95 \\
\hline F_GINT & 690 & 61.7813 & 20.01479 & 10 & 100 \\
\hline F_TAX & 690 & 61.66 & 15.17581 & 29.8 & 94 \\
\hline F_GSPEN & 690 & 36.87377 & 18.7848 & 0 & 79.7 \\
\hline F_BUS & 690 & 76.2371 & 10.45593 & 53.7 & 100 \\
\hline F_LAB & 420 & 60.61524 & 13.22186 & 31 & 100 \\
\hline F_MON & 690 & 78.79435 & 12.24109 & 0 & 94.2 \\
\hline F_TRAD & 690 & 81.45 & 7.307702 & 46.8 & 88 \\
\hline F_INV & 690 & 73.35507 & 12.62718 & 30 & 95 \\
\hline F_FIN & 690 & 67.53623 & 13.91513 & 30 & 90 \\
\hline Soure Auth & & & & & \\
\hline
\end{tabular}

Source: Author.

Firstly, we conduct a correlation analysis to see the basics of the relationships between dependent independent and control variables for each country (Graph from 10 to).

In Graph 10 we observe correlation between subindex Property rights and dependent variable Economic growth and we can see that the association is negative and statistically significant $(\mathrm{r}=-0.24, \mathrm{p}<0.0001)$. 
Graph 10. Correlation between subindex Property rights and GDP per capita growth (annual $\%)$

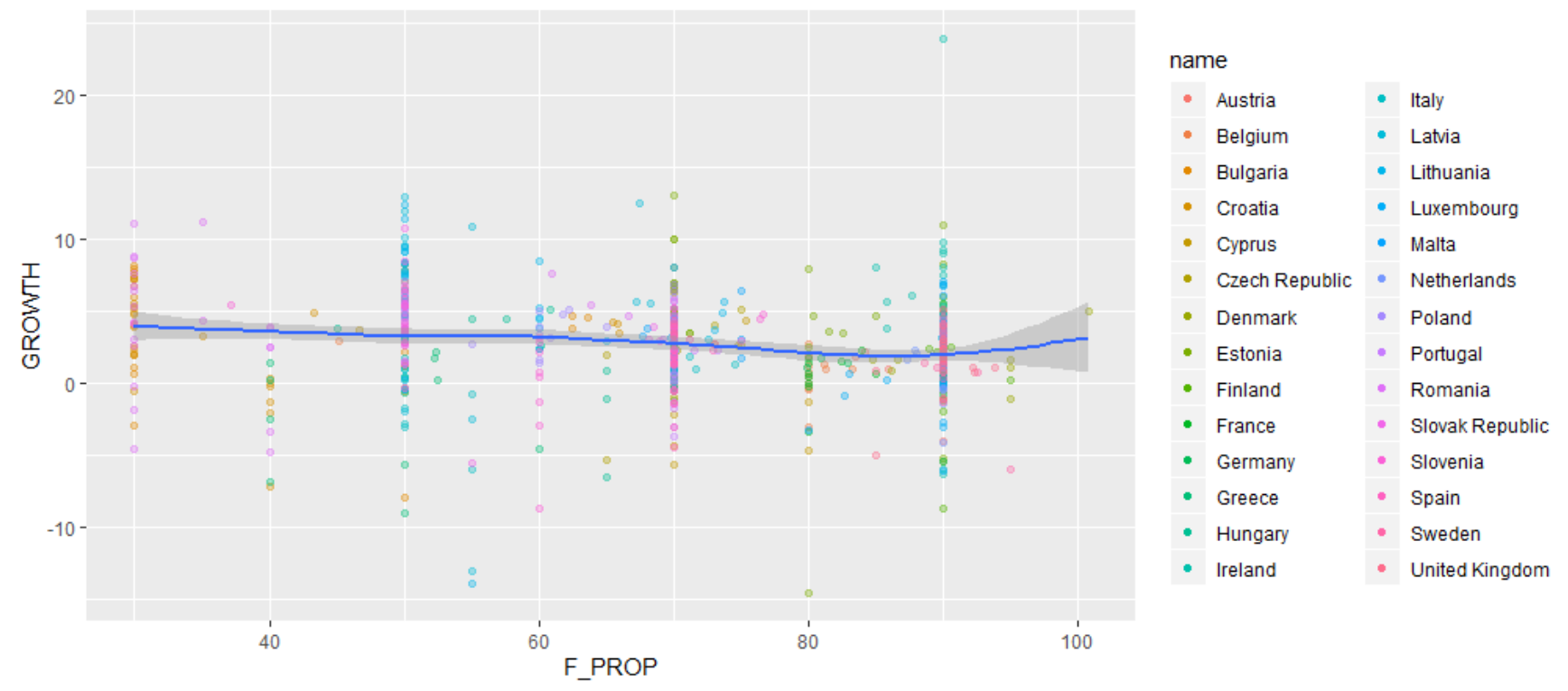

Source: Author.

Graph 11 shows the correlation between subindex of economic freedom Government integrity and dependent variable Economic growth in the selected sample of countries. We can see that the association is negative and statistically significant $(r=-0.27, p<0.0001)$.

Graph 11. Correlation between subindex Government integrity and GDP per capita growth (annual \%)

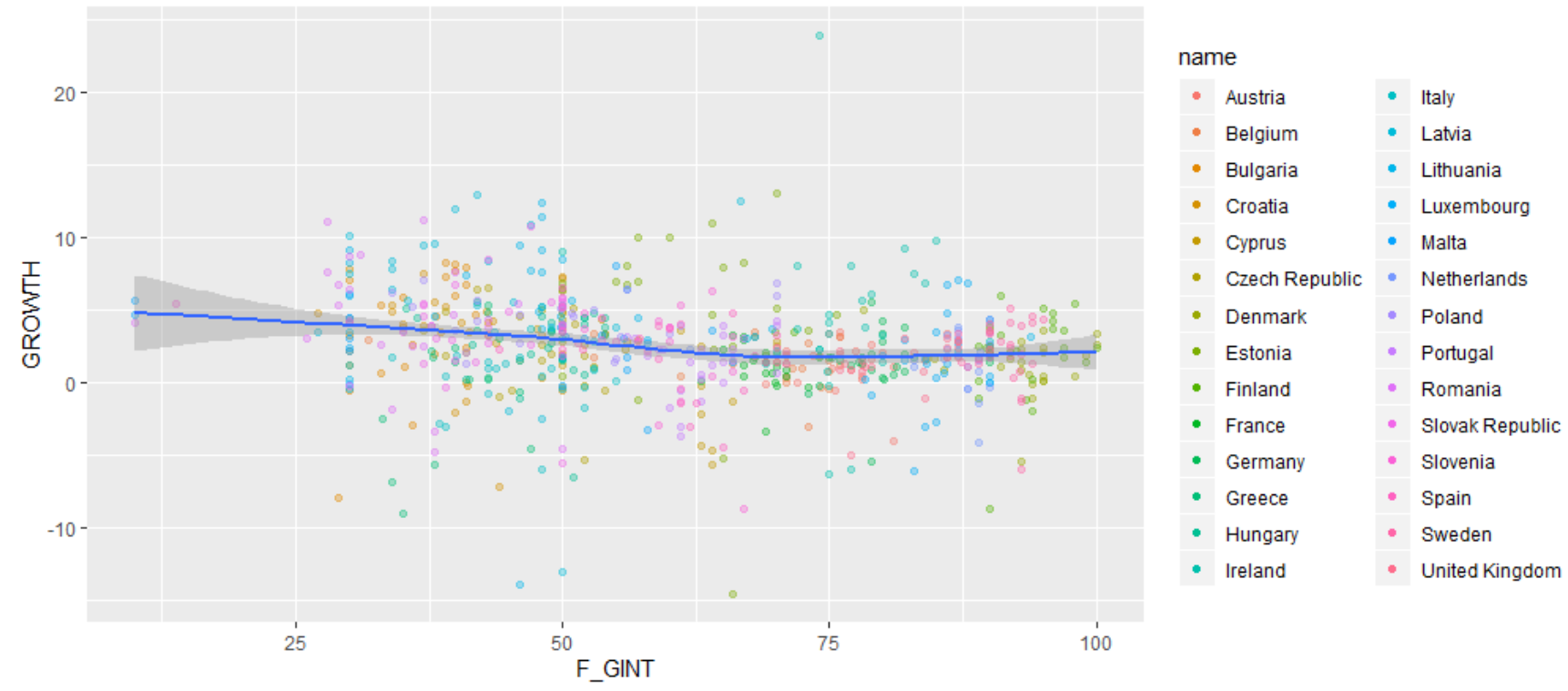

Source: Author. 
The relationship between Economic growth and subindex Tax burden is positive and statistically significant $(r=0.28, \mathrm{p}<0.0001)$ as can be seen in Graph 12.

Graph 12. Correlation between subindex Tax burden and GDP per capita growth (annual \%)

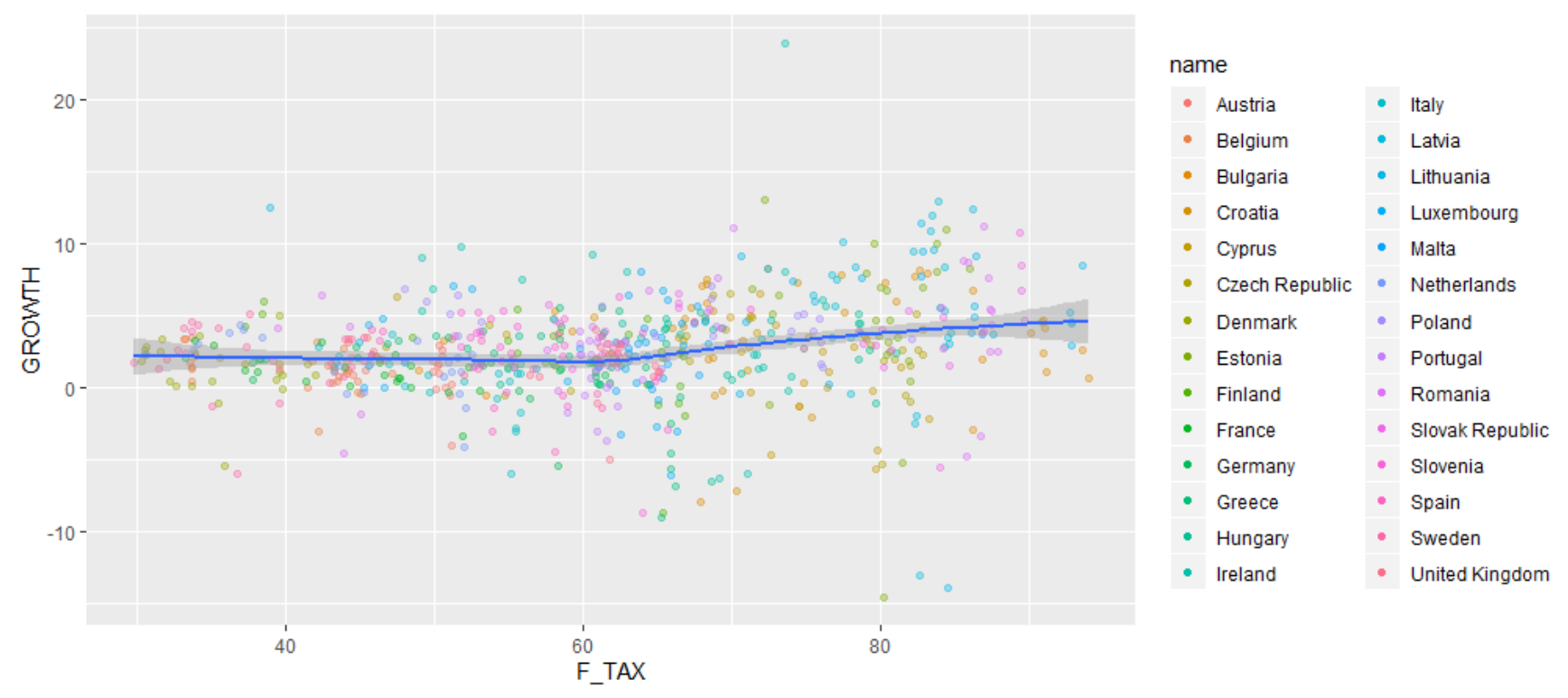

Source: Author.

Graph 13 shows that the association between dependent variable and (one of) the independent variable - subindex Government spending is positive and statistically significant $(\mathrm{r}=0.31$, $\mathrm{p}<0.0001)$.

Graph 13. Correlation between subindex Government spending and GDP per capita growth (annual \%)

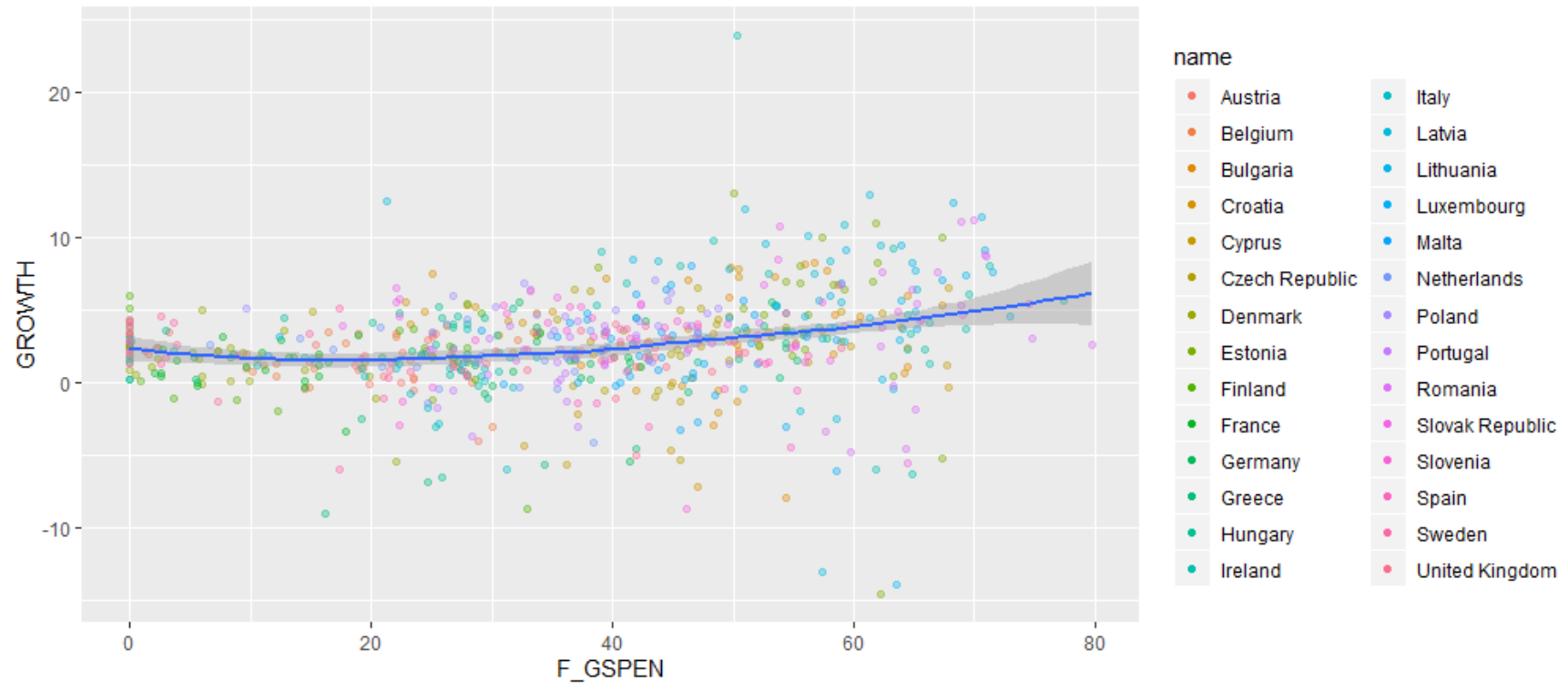

Source: Author. 
Ivana Brkić

If we observe the relationship between Economic growth and subindex Business freedom in the selected sample (Graph 14), we can notice that the association is negative and statistically significant $(\mathrm{r}=-0.26, \mathrm{p}<0.0001)$.

Graph 14. Correlation between subindex Business freedom and GDP per capita growth (annual \%)

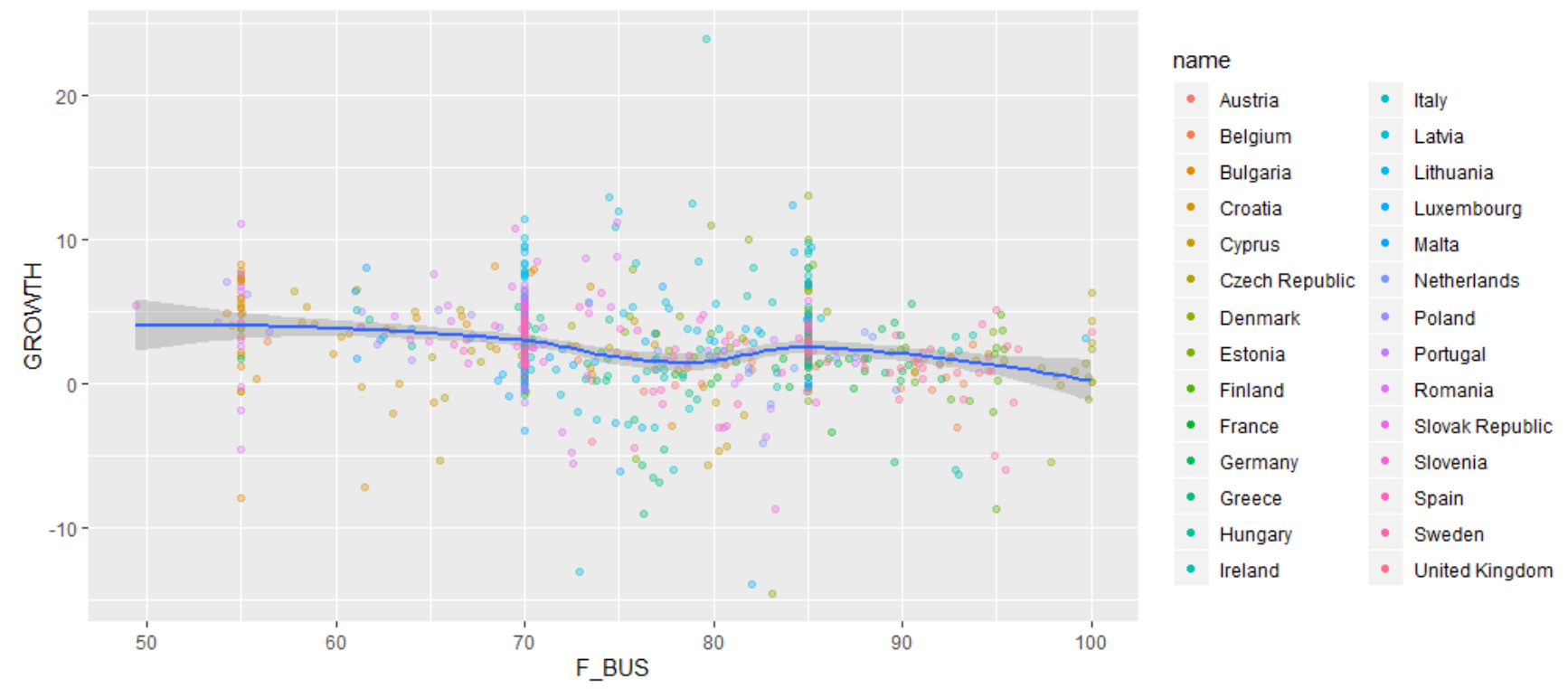

Source: Author.

There is no statistically significant relationship between Economic growth and subindex Labor freedom ( $\mathrm{r}=0.12, \mathrm{p}=0.01)$ - Graph 15 , which also applies to the relationship between Economic growth and subindex Monetary freedom presented in Graph 16 ( $\mathrm{r}=-0.003$, $\mathrm{p}=0.919)$.

Graph 15. Correlation between subindex Labor freedom and GDP per capita growth (annual $\%)$

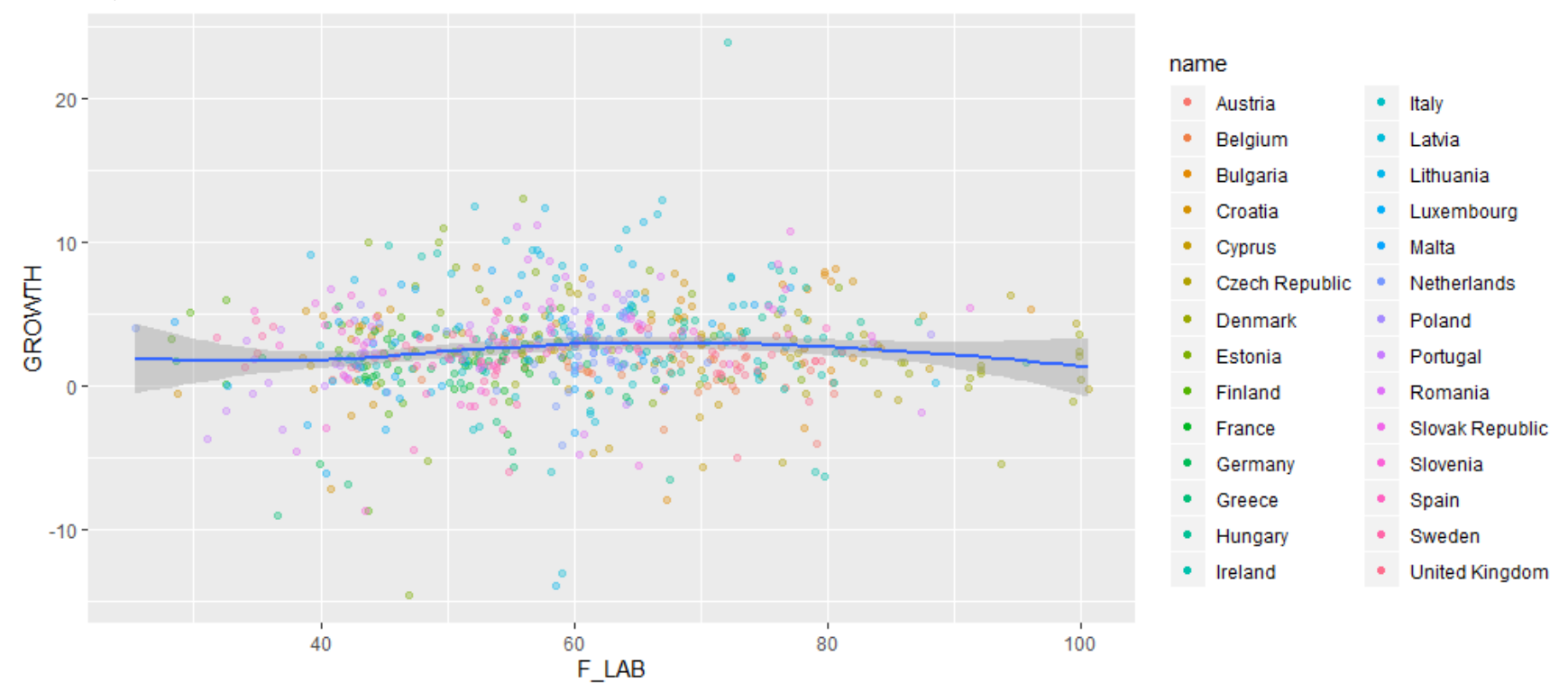

Source: Author. 
Graph 16. Correlation between subindex Monetary freedom and GDP per capita growth (annual \%)

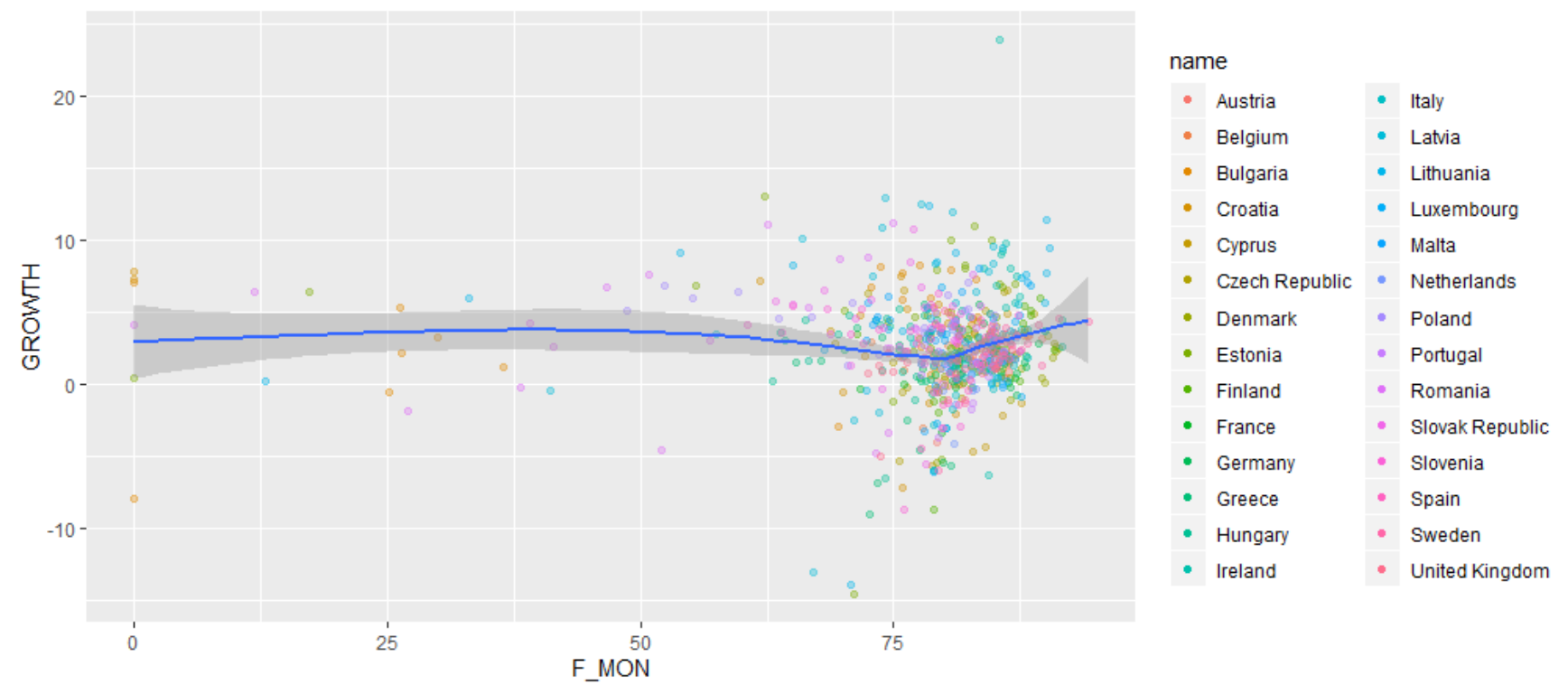

Source: Author.

A negative, statistically significant relationship is established between the economic freedom subindices Trade freedom $(\mathrm{r}=-0.27, \mathrm{p}<0.0001)$ and Economic growth (Graph 17), as well as between Investment freedom $(r=-0.21, p<0.0001)$ and Economic growth (Graph 18).

Graph 17. Correlation between subindex Trade freedom and GDP per capita growth (annual $\%)$

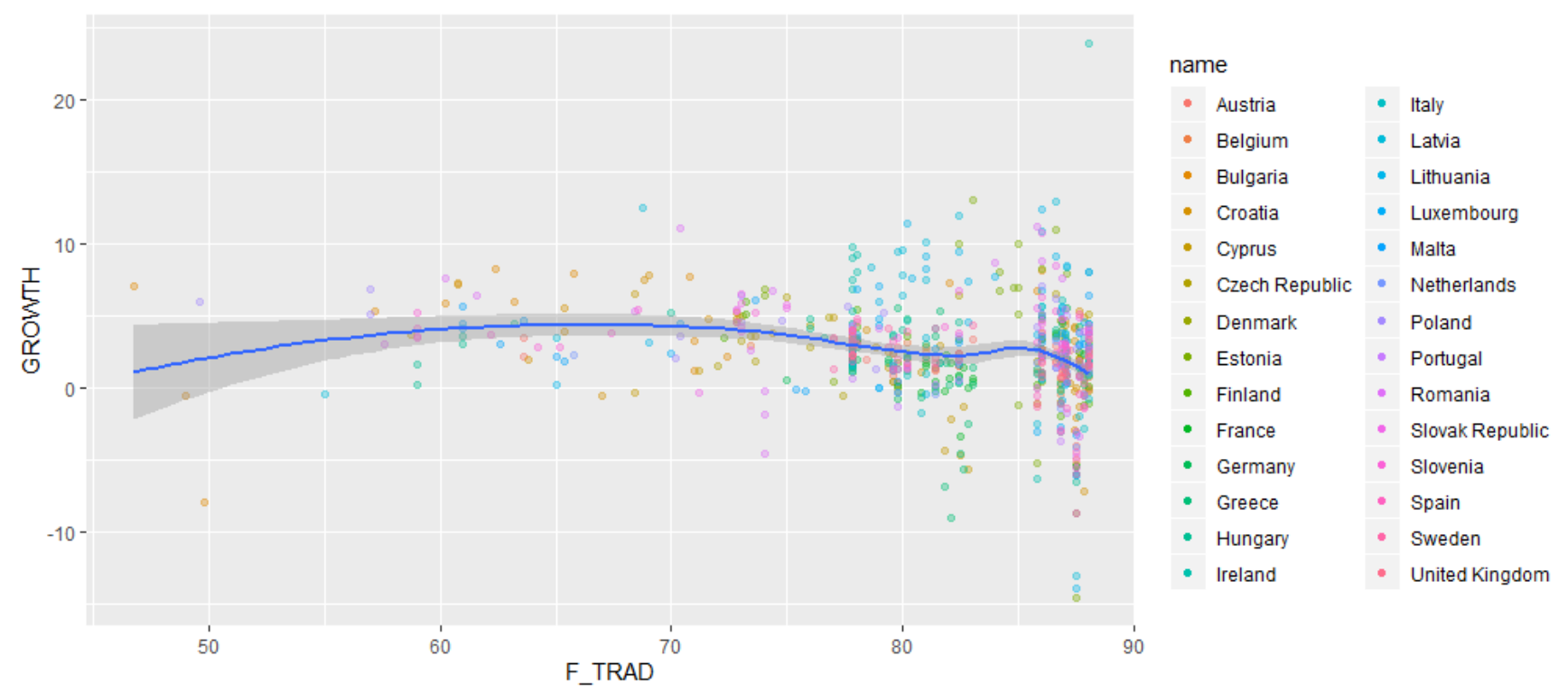

Source: Author. 
Graph 18. Correlation between subindex Investment freedom and GDP per capita growth (annual \%)

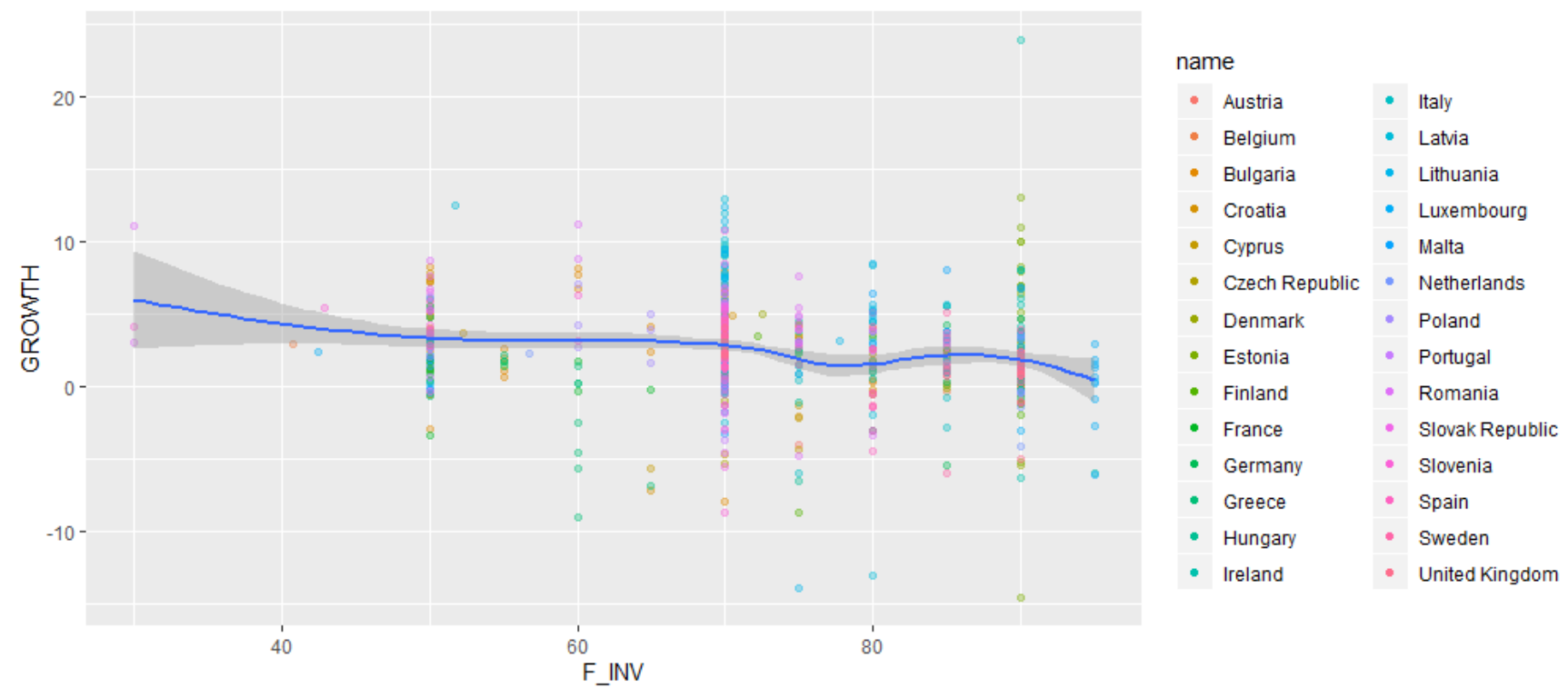

Source: Author.

Finally, we focused on the relationship between Economic growth and subindex Financial freedom and we noticed that the association is not statistically significant $(r=-0.08, p=0.02)$.

Graph 19. Correlation between subindex Financial freedom and GDP per capita growth (annual \%)

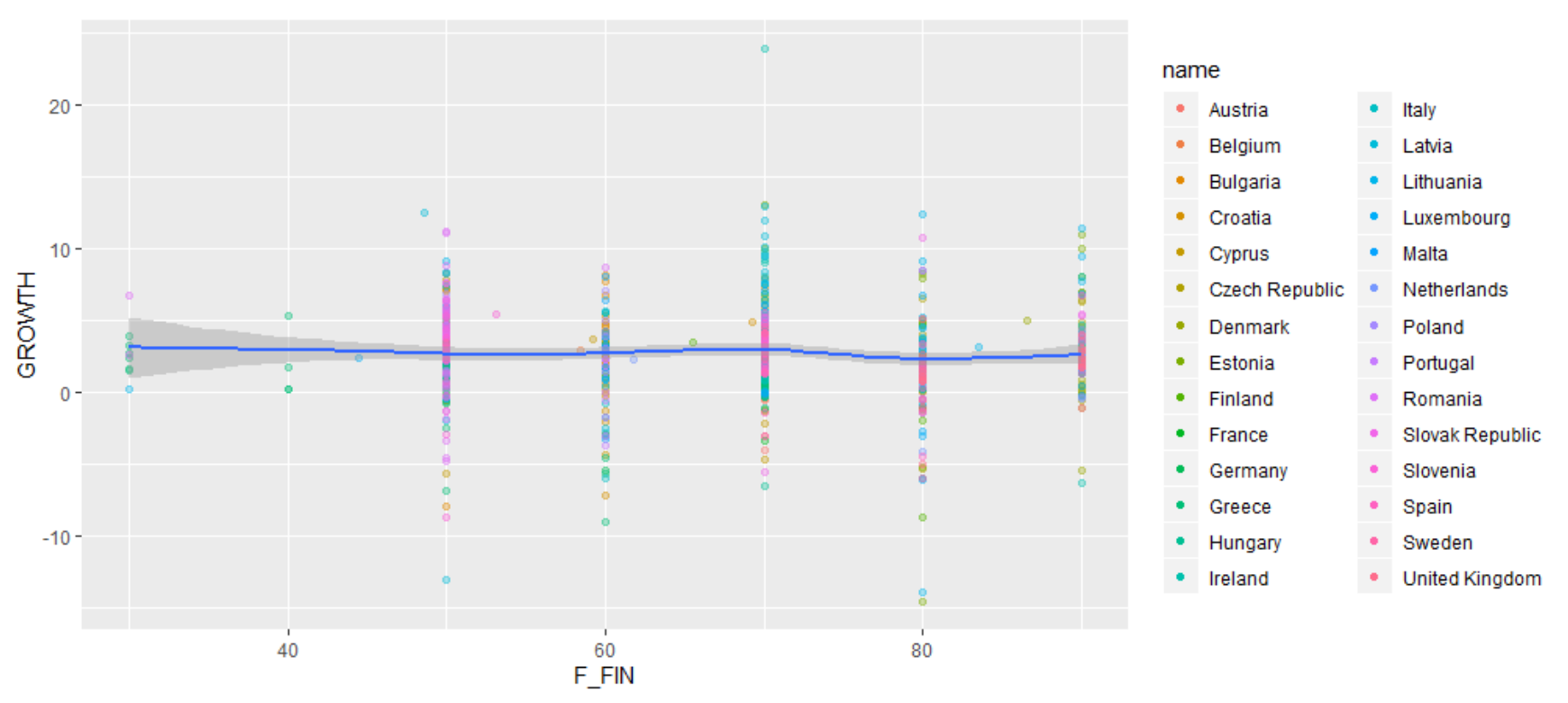

Source: Author. 
Figure 2 and Table 20 present the correlation between variables of this panel data.

Figure 2. Correlation between variables of panel data

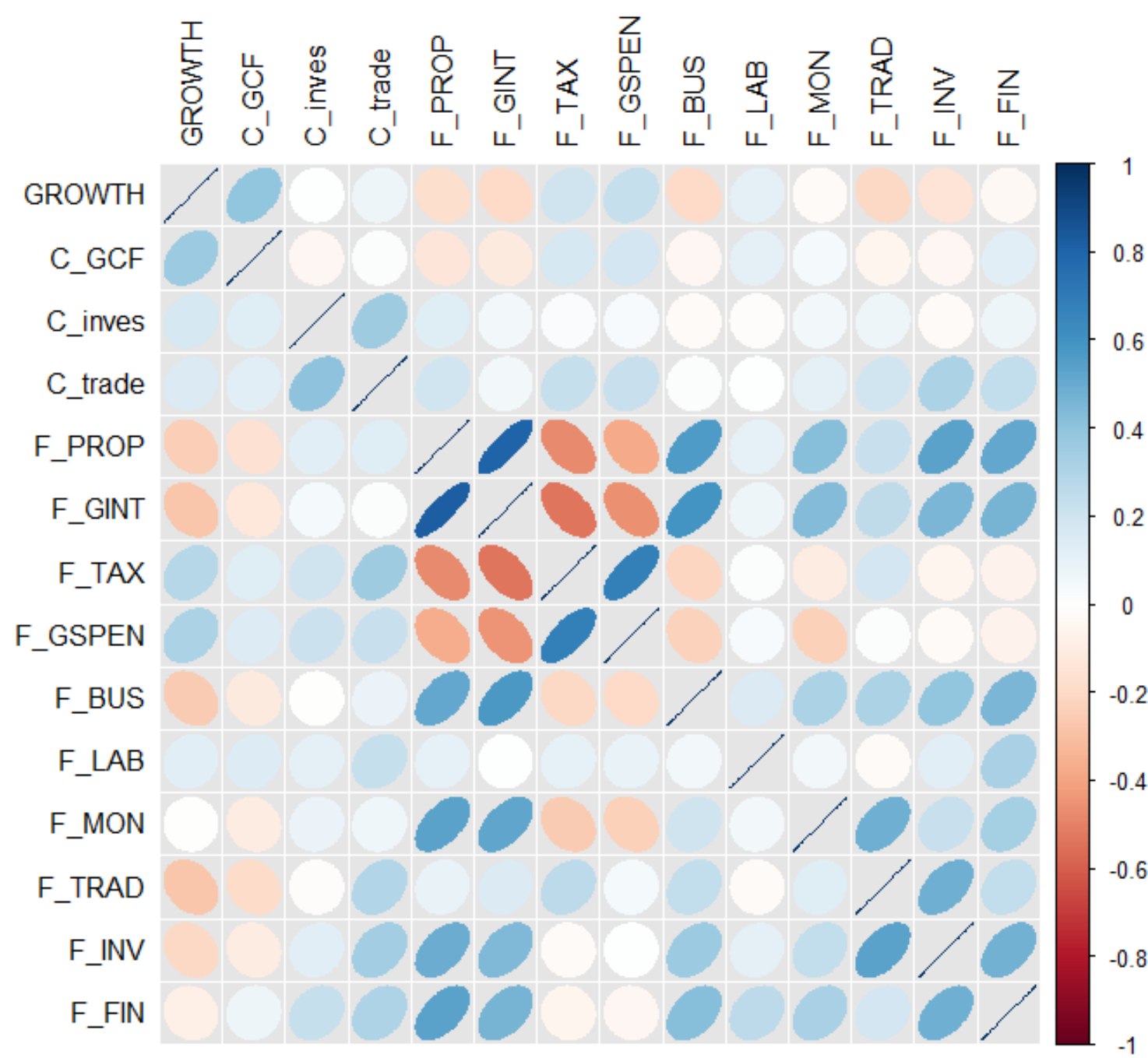

Source: Author. 
Table 20. Correlation between variables of panel data

\begin{tabular}{|c|c|c|c|c|c|c|c|c|c|c|c|c|c|c|c|}
\hline & & GROWTH & C_gcf & C_inves & C_trade & F_PROP & F_GINT & F_TAX & F_GSPEN & F_BUS & F_LAB & F_MON & F_TRAD & F_INV & F_FIN \\
\hline \multirow[t]{14}{*}{$\mathrm{r}$} & GROWTH & 1 & 0.392047 & 0.000549 & 0.077037 & -0.17518 & -0.19959896 & 0.208824 & 0.234674 & -0.19382 & 0.116103 & -0.02083 & -0.20011 & -0.14989 & -0.03567 \\
\hline & C_GCF & 0.365831 & 1 & -0.04097 & 0.015072 & -0.1305 & -0.11751425 & 0.176822 & 0.189575 & -0.04708 & 0.11599 & 0.048873 & -0.05961 & -0.04827 & 0.121499 \\
\hline & C_inves & 0.172403 & 0.131556 & 1 & 0.359274 & 0.13556 & 0.058743621 & 0.028659 & 0.030075 & -0.02044 & -0.0182 & 0.053264 & 0.073794 & -0.0253 & 0.074555 \\
\hline & C_trade & 0.159992 & 0.127574 & 0.408037 & 1 & 0.195467 & 0.052111995 & 0.236398 & 0.222421 & 0.019826 & 0.008835 & 0.110853 & 0.196311 & 0.319114 & 0.244255 \\
\hline & F_PROP & -0.24088 & -0.15688 & 0.129007 & 0.134108 & 1 & 0.805480869 & -0.47267 & -0.37602 & 0.563481 & 0.109241 & 0.427708 & 0.228409 & 0.532333 & 0.513259 \\
\hline & F_GINT & -0.27208 & -0.12506 & 0.048075 & 0.010445 & 0.827427 & 1 & -0.53611 & -0.45742 & 0.599348 & 0.073409 & 0.434647 & 0.259394 & 0.459865 & 0.466935 \\
\hline & F_TAX & 0.285685 & 0.130985 & 0.207103 & 0.35205 & -0.47282 & -0.5385514 & 1 & 0.685562 & -0.21693 & 0.011434 & -0.10837 & 0.183005 & -0.05951 & -0.06696 \\
\hline & F_GSPEN & 0.31643 & 0.144427 & 0.216705 & 0.225508 & -0.36727 & -0.44733446 & 0.681883 & 1 & -0.22132 & 0.036747 & -0.23579 & 0.018623 & -0.02413 & -0.064 \\
\hline & F_BUS & -0.25517 & -0.11244 & -0.00872 & 0.086983 & 0.517887 & 0.573479323 & -0.20007 & -0.19209 & 1 & 0.156715 & 0.316047 & 0.314671 & 0.394135 & 0.455887 \\
\hline & F_LAB & 0.122194 & 0.147872 & 0.111864 & 0.236964 & 0.103209 & 0.009562117 & 0.109118 & 0.095146 & 0.052408 & 1 & 0.054273 & -0.02565 & 0.126086 & 0.325256 \\
\hline & F_MON & -0.00388 & -0.10606 & 0.086316 & 0.064159 & 0.535914 & 0.527133847 & -0.25712 & -0.23379 & 0.207659 & 0.052056 & 1 & 0.483932 & 0.220918 & 0.335249 \\
\hline & F_TRAD & -0.27087 & -0.18277 & -0.01421 & 0.293389 & 0.091395 & 0.151358658 & 0.266903 & 0.044839 & 0.243584 & -0.02113 & 0.130978 & 1 & 0.487256 & 0.245908 \\
\hline & F_INV & -0.20926 & -0.10441 & 0.128561 & 0.347969 & 0.492067 & 0.444648528 & -0.02958 & 0.002656 & 0.367911 & 0.118376 & 0.248891 & 0.530416 & 1 & 0.477053 \\
\hline & F_FIN & -0.08536 & 0.072726 & 0.238965 & 0.301464 & 0.534397 & 0.467335963 & -0.05446 & -0.04551 & 0.42732 & 0.266661 & 0.320543 & 0.186403 & 0.489965 & 1 \\
\hline \multirow[t]{14}{*}{$\mathrm{p}$} & GROWTH & 1 & $<0.001$ & 0.988607 & 0.042181 & $<0.001$ & $<0.001$ & $<0.001$ & $<0.001$ & $<0.001$ & 0.017296 & 0.584967 & $<0.001$ & $<0.001$ & 0.349518 \\
\hline & C_gcf & $<0.001$ & 1 & 0.287068 & 0.69142 & 0.000595 & 0.002003454 & $<0.001$ & $<0.001$ & 0.217094 & 0.017405 & 0.200088 & 0.118005 & 0.205694 & 0.001397 \\
\hline & C_inves & $<0.001$ & 0.0006 & 1 & $<0.001$ & 0.000421 & 0.127903055 & 0.457943 & 0.436013 & 0.596626 & 0.710554 & 0.167529 & 0.055693 & 0.512386 & 0.053208 \\
\hline & C_trade & $<0.001$ & 0.000742 & $<0.001$ & 1 & $<0.001$ & 0.171837731 & $<0.001$ & $<0.001$ & 0.603399 & 0.85674 & 0.003574 & $<0.001$ & $<0.001$ & $<0.001$ \\
\hline & F_PROP & $<0.001$ & $<0.001$ & 0.000795 & 0.000416 & 1 & $<0.001$ & $<0.002$ & $<0.002$ & $<0.001$ & 0.025168 & $<0.001$ & $<0.001$ & $<0.001$ & $<0.001$ \\
\hline & F_GINT & $<0.001$ & 0.001003 & 0.212919 & 0.784337 & $<0.001$ & 1 & $<0.003$ & $<0.003$ & $<0.002$ & 0.133102 & $<0.001$ & $<0.001$ & $<0.001$ & $<0.001$ \\
\hline & F_TAX & $<0.001$ & 0.000567 & $<0.001$ & $<0.001$ & $<0.001$ & $<0.001$ & 1 & $<0.004$ & $<0.003$ & 0.815261 & 0.004375 & $<0.001$ & 0.11836 & 0.07882 \\
\hline & F_GSPEN & $<0.001$ & 0.000142 & $<0.001$ & $<0.001$ & $<0.001$ & $<0.002$ & $<0.001$ & 1 & $<0.004$ & 0.452596 & $<0.001$ & 0.625309 & 0.526957 & 0.092987 \\
\hline & F_BUS & $<0.001$ & 0.003123 & 0.821374 & 0.022408 & $<0.001$ & $<0.003$ & $<0.002$ & $<0.001$ & 1 & 0.001273 & $<0.001$ & $<0.001$ & $<0.001$ & $1.03 \mathrm{E}-36$ \\
\hline & F_LAB & 0.012205 & 0.00238 & 0.022172 & $<0.001$ & 0.034472 & $<0.004$ & 0.025335 & 0.051353 & 0.283907 & 1 & 0.267102 & 0.600134 & 0.009692 & $<0.001$ \\
\hline & F_MON & 0.919057 & 0.005323 & 0.025139 & 0.092419 & $<0.001$ & $<0.005$ & $<0.001$ & $<0.001$ & $<0.001$ & 0.287155 & 1 & $<0.001$ & $<0.001$ & $<0.001$ \\
\hline & F_TRAD & $<0.001$ & $<0.001$ & 0.712919 & $<0.001$ & 0.016331 & $<0.006$ & $<0.002$ & 0.23948 & $<0.002$ & 0.66596 & 0.000562 & 1 & $<0.001$ & $<0.001$ \\
\hline & F_INV & $<0.002$ & 0.006087 & 0.000829 & $<0.001$ & $<0.001$ & $<0.007$ & 0.437949 & 0.944477 & $<0.003$ & 0.015212 & $<0.001$ & $<0.001$ & 1 & $<0.001$ \\
\hline & F_FIN & 0.024938 & 0.056387 & $<0.001$ & $<0.001$ & $<0.001$ & $<0.008$ & 0.152999 & 0.232507 & $<0.004$ & $<0.001$ & $<0.001$ & $<0.001$ & $<0.001$ & 1 \\
\hline
\end{tabular}

Source: Author. 
Multicolinearity between independent variables was detected (VIF(F_prop)=4.77, $\operatorname{VIF}\left(F_{\text {_gint }}\right)=6.76, \quad \operatorname{VIF}\left(\mathrm{F}_{-}\right.$tax $)=3.34, \quad \operatorname{VIF}\left(\mathrm{F}_{\text {_gspen }}\right)=2.51, \quad \mathrm{VIF}\left(\mathrm{F} \_\right.$bus $)=2.69$, $\operatorname{VIF}\left(F \_l a b\right)=1.18, \operatorname{VIF}\left(F \_m o n\right)=1.24, \operatorname{VIF}\left(F \_t r a d\right)=1.36, \operatorname{VIF}\left(F \_\right.$inv $)=2.65, \operatorname{VIF}\left(F \_\right.$fin $)=2.01$, $\operatorname{VIF}\left(C \_\right.$gdf $)=1.22, \operatorname{VIF}\left(C_{-}\right.$inves $)=1.35, \operatorname{VIF}\left(C_{-}\right.$trade $\left.)=1.65\right)$.

In the next segment we will present full fixed and random effects model (Table 21 and 22).

Table 21. Fixed effects model - the impact of subindices of economic freedom on economic growth in the European Union countries

\begin{tabular}{|l|r|r|r|r|}
\multicolumn{1}{|c|}{ Variable } & Estimate & SE & t value & \multicolumn{2}{c|}{$\mathrm{p}$} \\
\hline F prop & -0.004 & 0.02 & -0.18 & 0.85 \\
\hline F gint & -0.088 & 0.03 & -2.69 & 0.01 \\
\hline F tax & -0.024 & 0.05 & -0.47 & 0.64 \\
\hline F gspen & -0.065 & 0.02 & -3.43 & $<0.001$ \\
\hline F bus & -0.04 & 0.03 & -1.15 & 0.25 \\
\hline F lab & 0.036 & 0.03 & 1.29 & 0.21 \\
\hline F mon & 0.315 & 0.04 & 7.53 & $<0.001$ \\
\hline F trad & -0.13 & 0.06 & -2.2 & 0.03 \\
\hline F inv & -0.042 & 0.03 & -1.67 & 0.11 \\
\hline F fin & -0.037 & 0.03 & -1.25 & 0.21 \\
\hline C gcf & 0.435 & 0.05 & 9.47 & $<0.001$ \\
\hline C inves & 0.002 & 0 & 0.4 & 0.69 \\
\hline C trade & 0.05 & 0.01 & 4.6 & $<0.001$ \\
\hline F-statistic: 20.1 on 13 and 377 DF, $p$-value: $<0.001$ & $\mathrm{R}^{2}=40.95 \%$ & Adjusted $\mathrm{R}^{2}=$ \\
\hline 34.7\% & & & & \\
\hline Source: Author & & & & \\
\hline
\end{tabular}

Source: Author.

Table 22. Random effects model - the impact of subindices of economic freedom on economic growth in the European Union countries

\begin{tabular}{|l|r|r|r|r|}
\hline Variable & Estimate & SE & t value & p \\
\hline F prop & -0.004 & 0.023 & -0.184 & 0.854 \\
\hline F gint & -0.088 & 0.033 & -2.693 & 0.007 \\
\hline F tax & -0.024 & 0.051 & -0.468 & 0.64 \\
\hline F gspen & -0.065 & 0.019 & -3.433 & 0.001 \\
\hline
\end{tabular}


Ivana Brkić

\begin{tabular}{|l|r|r|r|r|}
\hline F bus & -0.04 & 0.035 & -1.152 & 0.25 \\
\hline F lab & 0.036 & 0.028 & 1.293 & 0.197 \\
\hline F mon & 0.315 & 0.042 & 7.527 & $<0.001$ \\
\hline F trad & -0.13 & 0.059 & -2.196 & 0.029 \\
\hline F inv & -0.042 & 0.025 & -1.672 & 0.095 \\
\hline F fin & -0.037 & 0.03 & -1.254 & 0.211 \\
\hline C_gcf & 0.435 & 0.046 & 9.467 & $<0.001$ \\
\hline C inves & 0.002 & 0.005 & 0.4 & 0.689 \\
\hline C trade & 0.05 & 0.011 & 4.598 & $<0.001$ \\
\hline F-statistic: 205.1 on 13 DF, p-value: $<0.001$ & $\mathrm{R}^{2}=33.73 \%$ & Adjusted $\mathrm{R}^{2}=31.61 \%$ \\
\hline
\end{tabular}

Source: Author.

We used Hausman test (or the test for endogeneity) to test whether the unique errors are correlated with the regressor. The results of the comparison between the fixed model and the random model are as follows:

chisq $=61.7, \mathrm{df}=13, \mathrm{p}$-value $<0.001$. The result indicates that we need to apply fixed effect model for our data.

Assumptions:

1. We tested cross-sectional dependence using the Breusch-Pagan LM test of independence (Breusch \& Pagan, 1979, Hoechle, 2007). The null hypothesis in the B$\mathrm{P} / \mathrm{LM}$ test of independence is that residuals across entities are not correlated. B-P/LM and Pasaran CD (cross-sectional dependence) tests are used to test whether the residuals are correlated across entities. Result was shown chisq $=1057.6, \mathrm{df}=378, \mathrm{p}$ $<0.01$, so we can conclude that our model has cross-sectional dependence.

2. We tested serial correlation (autocorrelation) using the Breusch-Godfrey test. The null hypothesis of this test is that there is no serial correlation. Result was shown chisq $=$ $100.5, \mathrm{df}=14, \mathrm{p}<0.01$. According to the result, there is a serial correlation.

3. We tested stationarity using the Dickey-Fuller test. The hull hypothesis of this test is that the series is nonstationary. The result was shown for dependent variable Growth: Dickey-Fuller $=-10.826, p=0.01$. According to the result, there are no unit roots present. For independent variables: F_prop : Dickey-Fuller $=-4.315$, Lag order $=2$, p- 
value $=0.01$,

F_gint: Dickey-Fuller $=-3.82$, Lag order $=2$, p-value $=0.01$,

F_tax: Dickey-Fuller $=-4.914$, Lag order $=2$, p-value $=0.01$,

F_gspen: Dickey-Fuller $=-5.921$, Lag order $=2, p$-value $=0.01$,

F_bus: Dickey-Fuller $=-6.005$, Lag order $=2$, p-value $=0.01$,

F_lab: Dickey-Fuller $=-7.267$, Lag order $=2$, p-value $=0.01$,

F_mon: Dickey-Fuller $=-8.906$, Lag order $=2, p$-value $=0.01$,

F_trad: Dickey-Fuller $=-8.786$, Lag order $=2$, p-value $=0.01$,

F_inv: Dickey-Fuller $=-6.051$, Lag order $=2$, p-value $=0.01$,

F_fin:Dickey-Fuller $=-5.998, \operatorname{Lag}$ order $=2, p$-value $=0.01$,

C_GCF: Dickey-Fuller $=-3.25$, Lag order $=2$, p-value $=0.025$,

C_inves: Dickey-Fuller $=-10.159$, Lag order $=2$, p-value $=0.01$ and C_trade:

Dickey-Fuller $=-3.8492$, Lag order $=2, \mathrm{p}$-value $=0.01654$. According to the result, there are no unit roots present in independent variables.

4. We tested heteroskedasticity using the Breusch-Pagan test. The null hypothesis of this test is that there is homoskedasticity. The result was shown $\mathrm{BP}=167.6$, df $=13$, $\mathrm{p}<0.01$. According to the result, there is heteroskedasticity.

The problem with cross-sectional dependence was solved by including time effects in our model. We tested statistical difference between fixed effects model without time effects and with time effects by $\mathrm{F}$ test for individual effects and obtained the following results $\mathrm{F}=$ 15.841 , df1 $=14$, df $2=363, \mathrm{p}<0.01$. According to this result, we can conclude that it is better to use time-fixed effects.

The problem of autocorrelation and heteroskedasticity was solved by using the robust covariance matrix estimator HAC (Andrews, 1991).

Below (Table 23) we present an improved model. 
Ivana Brkić

Table 23. Improved fixed effects model - the impact of subindices of economic freedom on economic growth in European Union countries

\begin{tabular}{|c|c|c|c|c|}
\hline Variable & Estimate & SE & $\mathrm{t}$ value & $\mathrm{p}$ \\
\hline F prop & 0.017 & 0.019 & 0.897 & 0.371 \\
\hline F gint & -0.076 & 0.031 & -2.41 & $0.016^{*}$ \\
\hline $\mathrm{F} \operatorname{tax}$ & -0.015 & 0.057 & -0.271 & 0.786 \\
\hline F gspen & -0.018 & 0.022 & -0.799 & 0.425 \\
\hline F bus & -0.022 & 0.033 & -0.68 & 0.497 \\
\hline F lab & 0.02 & 0.032 & 0.636 & 0.525 \\
\hline F mon & 0.098 & 0.061 & 1.624 & 0.105 \\
\hline$F$ trad & -0.024 & 0.058 & -0.407 & 0.685 \\
\hline $\mathrm{F}$ inv & -0.053 & 0.032 & -1.628 & 0.104 \\
\hline F fin & -0.033 & 0.033 & -1.017 & 0.31 \\
\hline C_gcf & 0.327 & 0.068 & 4.809 & $<0.001$ \\
\hline C inves & -0.002 & 0.006 & -0.312 & 0.755 \\
\hline C trade & 0.028 & 0.027 & 1.021 & 0.308 \\
\hline \multicolumn{3}{|c|}{ F-statistic: 7.2 on 13 and $636 \mathrm{DF}, \mathrm{p}$-value: $<0.001$} & $\mathrm{R}^{2}=30.5 \%$ & $2^{2}=28.7$ \\
\hline
\end{tabular}

Source: Author.

Statistically significant independent variable is $F$ gin $(p=0.016)$ and variable $C \operatorname{gcf}(p<0.001)$. It means that each 1 unit increase of $F$ gin causes decrease in Growth by 0.076 and each 1 unit increase of C_GCF causes increase in Growth by 0.327 .

We can see that variables $\mathrm{F}$ pro and $\mathrm{F}$ gint are in multicolinearity with other independent variables $\left(\operatorname{VIF}\left(\mathrm{F} \_\right.\right.$prop $)=4.77, \operatorname{VIF}\left(\mathrm{F} \_\right.$gint $\left.)=6.76\right)$. Below we present the model without them (Table 24 and 25).

Table 24. Reduced fixed effects model - the impact of subindices of economic freedom on economic growth in European Union countries

\begin{tabular}{|l|r|r|r|r|}
\hline \multicolumn{1}{|c|}{ Variable } & \multicolumn{1}{c|}{ Estimate } & \multicolumn{1}{c|}{ SE } & \multicolumn{1}{c|}{ t value } & \multicolumn{1}{c|}{ p } \\
\hline F tax & -0.03 & 0.051 & -0.59 & 0.556 \\
\hline F gspen & -0.072 & 0.019 & -3.848 & $<0.001$ \\
\hline F bus & -0.057 & 0.034 & -1.686 & 0.093 \\
\hline
\end{tabular}


Ivana Brkić

\begin{tabular}{|l|r|r|r|r|} 
F lab & 0.022 & 0.028 & 0.805 & 0.421 \\
\hline F mon & 0.307 & 0.042 & 7.389 & $<0.001$ \\
\hline F trad & -0.13 & 0.06 & -2.175 & 0.03 \\
\hline F inv & -0.047 & 0.025 & -1.857 & 0.064 \\
\hline F fin & -0.028 & 0.03 & -0.932 & 0.352 \\
\hline C_GCF & 0.435 & 0.046 & 9.514 & $<0.001$ \\
\hline C inves & 0 & 0.005 & -0.099 & 0.921 \\
\hline C trade & 0.051 & 0.011 & 4.701 & $<0.001$ \\
\hline F-statistic: 22.1 on 11 and 379 DF, $\mathrm{p}$-value: $<0.001$ & $\mathrm{R}^{2}=39.7 \%$ & Adjusted $\mathrm{R}^{2}=33.7 \%$ \\
\hline
\end{tabular}

Source: Author.

Table 25. Reduced random effects model - the impact of subindices of economic freedom on economic growth in European Union countries

\begin{tabular}{|l|r|r|r|r|}
\multicolumn{1}{|c|}{ Variable } & Estimate & SE & t value & \multicolumn{1}{c|}{ p } \\
\hline F tax & -0.03 & 0.051 & -0.59 & 0.556 \\
\hline F gspen & -0.072 & 0.019 & -3.848 & $<0.001$ \\
\hline F bus & -0.057 & 0.034 & -1.686 & 0.093 \\
\hline F lab & 0.022 & 0.028 & 0.805 & 0.421 \\
\hline F mon & 0.307 & 0.042 & 7.389 & $<0.001$ \\
\hline F trad & -0.13 & 0.06 & -2.175 & 0.03 \\
\hline F inv & -0.047 & 0.025 & -1.857 & 0.064 \\
\hline F fin & -0.028 & 0.03 & -0.932 & 0.352 \\
\hline C_gcf & 0.435 & 0.046 & 9.514 & $<0.001$ \\
\hline C inves & 0 & 0.005 & -0.099 & 0.921 \\
\hline C trade & 0.051 & 0.011 & 4.701 & $<0.001$ \\
\hline F-statistic: 203.6 on 11 DF, $p$-value: $<0.001$ & $\mathrm{R}^{2}=33.3 \%$ & Adjusted $\mathrm{R}^{2}=31.6 \%$ \\
\hline
\end{tabular}

Source: Author.

The Hausman test (or the test for endogeneity) was used in order to test whether the unique errors are correlated with the regressor. The results of the comparison between the fixed model and the random model are as follows:

chisq $=21.5, \mathrm{df}=11, \mathrm{p}$-value $=0.028$. The result indicates that we need to use fixed effect model for our data. 
Assumptions:

1. We tested cross-sectional dependence using the Breusch-Pagan LM test of independence (Breusch \& Pagan, 1979, Hoechle, 2007). The null hypothesis in the B$\mathrm{P} / \mathrm{LM}$ test of independence is that residuals across entities are not correlated. B-P/LM and Pasaran CD (cross-sectional dependence) tests are used to test whether the residuals are correlated across entities. Result was shown chisq $=1094.1, \mathrm{df}=378, \mathrm{p}$ $<0.01$, so we can conclude that our model has cross-sectional dependence.

2. We tested serial correlation (autocorrelation) using the Breusch-Godfrey test. The null hypothesis of this test is that there is no serial correlation. Result was shown chisq $=$ $100.8, \mathrm{df}=14, \mathrm{p}<0.01$. According to the result, there is a serial correlation.

3. We tested stationarity using the Dickey-Fuller test. The null hypothesis of this test is that the series is nonstationary. The result was shown for the dependent variable Growth: Dickey-Fuller $=-10.826, p=0.01$. According to the result, there are no unit roots. For independent variables:

F_tax: Dickey-Fuller $=-4.914$, Lag order $=2$, p-value $=0.01$,

F_gspen: Dickey-Fuller $=-5.921$, Lag order $=2, p$-value $=0.01$,

F_bus: Dickey-Fuller $=-6.005$, Lag order $=2$, p-value $=0.01$,

F_lab: Dickey-Fuller $=-7.267$, Lag order $=2$, p-value $=0.01$,

F_mon: Dickey-Fuller $=-8.906$, Lag order $=2, p$-value $=0.01$,

F_trad: Dickey-Fuller $=-8.786$, Lag order $=2$, p-value $=0.01$,

F_inv: Dickey-Fuller $=-6.051$, Lag order $=2, \mathrm{p}$-value $=0.01$,

F_fin:Dickey-Fuller $=-5.998, \operatorname{Lag}$ order $=2, \mathrm{p}$-value $=0.01$,

C_GCF: Dickey-Fuller $=-3.25$, Lag order $=2$, p-value $=0.025$,

C_inves: Dickey-Fuller $=-10.159$, Lag order $=2$, p-value $=0.01$ and C_trade:

Dickey-Fuller $=-3.8492$, Lag order $=2, \mathrm{p}$-value $=0.01654$. According to the result, there are no unit roots present in independent variables.

4. We tested heteroskedasticity using the Breusch-Pagan test. The null hypothesis of this test is that there is homoskedasticity. The result was shown $\mathrm{BP}=159.5$, $\mathrm{df}=11$, $\mathrm{p}<0.01$. According to the result, there is heteroskedasticity. 
Ivana Brkić

The problem with cross-sectional dependence we solved by including time effects in our model. We tested statistical difference between fixed effects model without time effects and with time effects by $\mathrm{F}$ test for individual effects and obtained the following results $\mathrm{F}=$ 15.941, df1 $=14$, df2 $=365, \mathrm{p}<0.01$.

According to these results, we can conclude that it is better to use time-fixed effects.

The problem of autocorrelation and heteroskedasticity was solved by using the robust covariance matrix estimator HAC (Andrews, 1991).

Table 26. Final fixed effects model - the impact of subindices of economic freedom on economic growth in European Union countries

\begin{tabular}{|c|c|c|c|c|}
\hline Variable & Estimate & SE & t value & $\mathrm{p}$ \\
\hline $\mathrm{F}$ tax & -0.029 & 0.045 & -0.66 & 0.51 \\
\hline F gspen & -0.024 & 0.017 & -1.407 & 0.16 \\
\hline $\mathrm{F}$ bus & -0.036 & 0.03 & -1.212 & 0.226 \\
\hline F lab & 0.012 & 0.023 & 0.509 & 0.611 \\
\hline F mon & 0.092 & 0.043 & 2.153 & 0.032 \\
\hline$F$ trad & -0.013 & 0.065 & -0.193 & 0.847 \\
\hline $\mathrm{F}$ inv & -0.056 & 0.021 & -2.597 & 0.01 \\
\hline F fin & -0.022 & 0.024 & -0.892 & 0.373 \\
\hline C_gcf & 0.326 & 0.045 & 7.176 & $<0.001$ \\
\hline C inves & -0.003 & 0.004 & -0.845 & 0.399 \\
\hline $\mathrm{C}$ trade & 0.027 & 0.011 & 2.489 & 0.013 \\
\hline \multicolumn{3}{|c|}{ F-statistic: 7.7 on 11 and $636 \mathrm{DF}, \mathrm{p}$-value: $<0.001$} & $8.9 \% \quad \mathrm{Ad}$ & $=27.3 \%$ \\
\hline
\end{tabular}

Source: Author.

Statistically significant independent variable is $F$ mon $(p=0.032), F$ inv $(p=0.01), C$ gcf $(\mathrm{p}<0.001)$ and variable $\mathrm{C}$ trade $(\mathrm{p}=0,013)$. It means that each 1 unit increase of $\mathrm{F}$ mon causes increase in Growth by 0.09 and also each 1 unit increase of $F$ inv causes decrease in Growth by 0.056 and each 1 unit increase of C_gcf causes increase in Growth by 0.326 and each 1 unit increase of $\mathrm{C}$ trade causes increase in Growth by 0.027 .

We can see that independent variable $\mathrm{F}$ mon is not in linear relationship with dependent variable Growth but it is a statistically significant predictor. This variable is called “suppressor variable” (Maassen \& Bakker, 2001). 


\subsection{RESULTS OF THE PANEL ANALYSIS ON THE IMPACT OF CHANGE OF ECONOMIC FREEDOM ON ECONOMIC GROWTH IN THE EU COUNTRIES}

In this segment we seek to explore the relationship between the change of economic freedom and economic growth in the selected sample of EU countries. Graph 20 presents a visualization of the scatterplots between Growth and Change Efi by countries. 
Graph 20. Relationship between independent and dependent variable in each country

\section{Relationship Between Growth and Change Efi}

By countries (1994-2018)
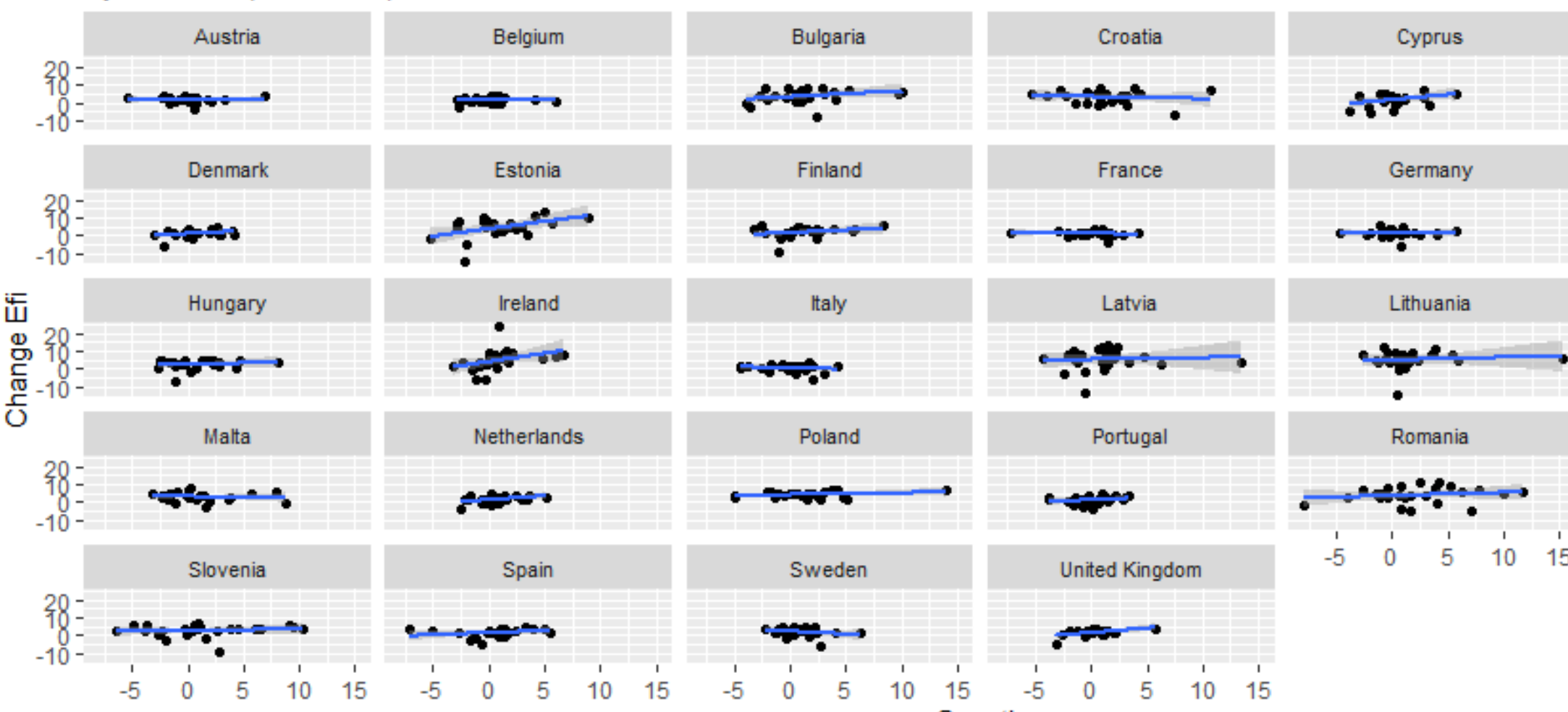

Czech Republic
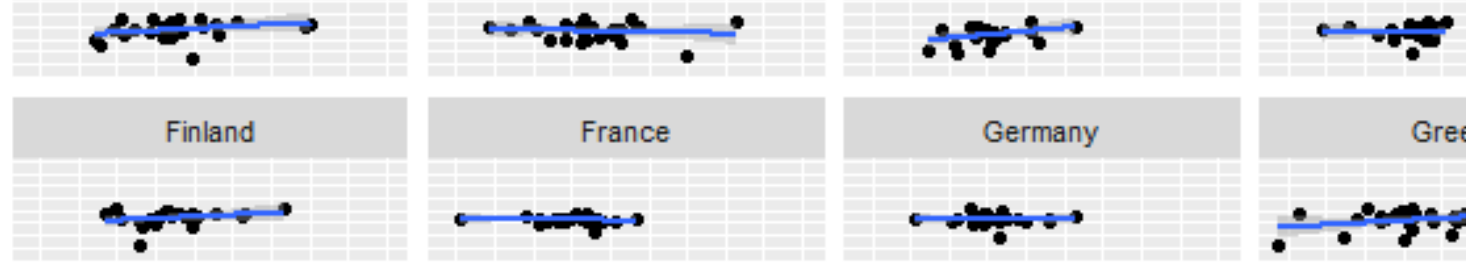

Italy

$\cos$

Poland

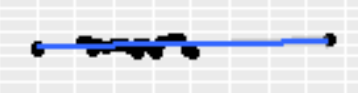

Sweden
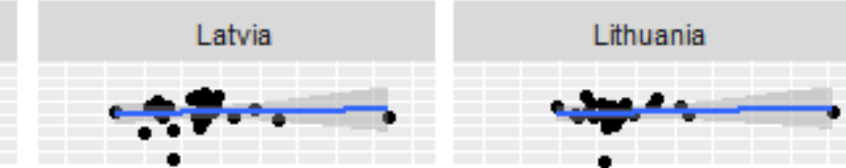

Portugal

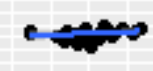

United Kingdom
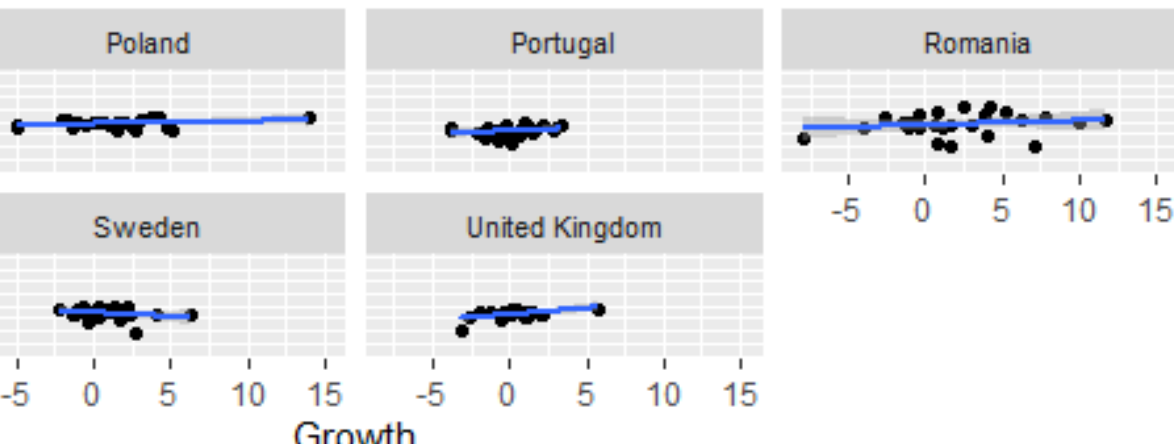

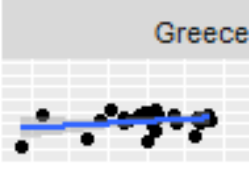

Luxembourg

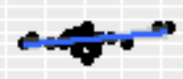

Slovak Republic

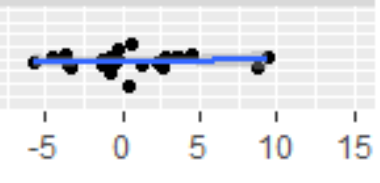

Source: Author. 
Ivana Brkić

Graph 21 shows the correlation between Change of index of economic freedom and Economic growth in the observed sample of countries. We can see that the association is positive and statistically significant $(r=0.185, \mathrm{p}<0.0001)$.

Graph 21. Correlation between Change of index of economic freedom and GDP per capita growth (annual \%)

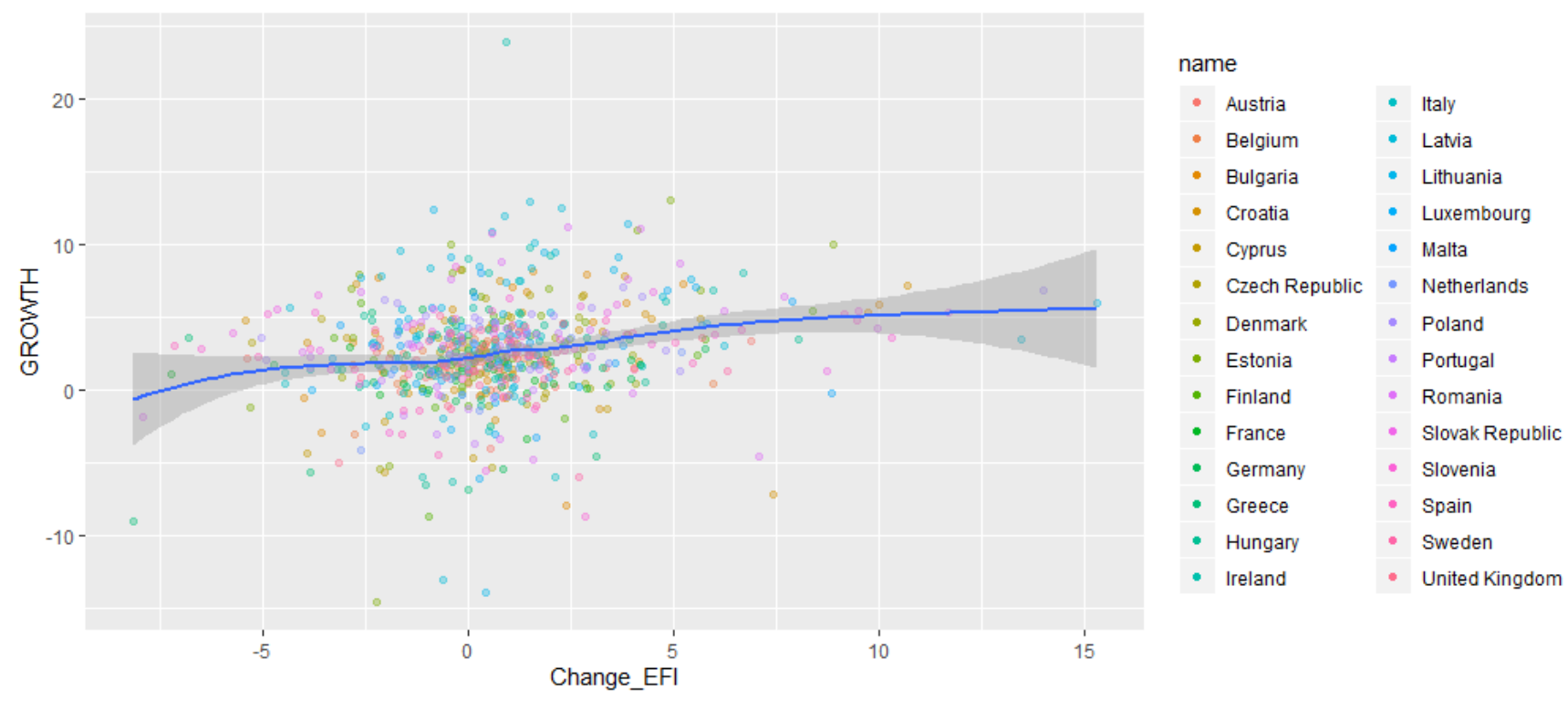

Source: Author.

Figure 3 and Table 27 present the correlation between variables of these panel data. Obviously, there is no strong correlation between variables. We detected significant correlation between Growth and Change Efi $(\mathrm{r}=0.19$, $\mathrm{p}<0.001)$, Growth and C_GCF $(\mathrm{r}=0.365, \mathrm{p}<0.001)$, Growth and C_Inves $(\mathrm{r}=0.17, \mathrm{p}<0.001)$ and Growth and C_trade $(\mathrm{r}=0.16$, $\mathrm{p}<0.001)$, between Change Efi and C_GCF ( $\mathrm{r}=0.09, \mathrm{p}=0.01)$, between C_GCF and C_inves $(r=0.13, p<0.001$ (and C_GCF and C_trade $(r=0.127, p<0.001)$ and also between C_inves and C_trade $(\mathrm{r}=0.359, \mathrm{p}<0.001)$.

Multicolinearity between dependent variables was not detected $(\operatorname{VIF}($ Change Efi) $=1.007$; $\mathrm{VIF}\left(\mathrm{C} \_\mathrm{GDF}\right)=1.009 ; \mathrm{VIF}(\mathrm{C}$ _inves $)=1.152$ and $\mathrm{VIF}\left(\mathrm{C} \_\right.$trade $\left.)=1.151\right)$. 
Figure 3. Correlation between variables of panel data

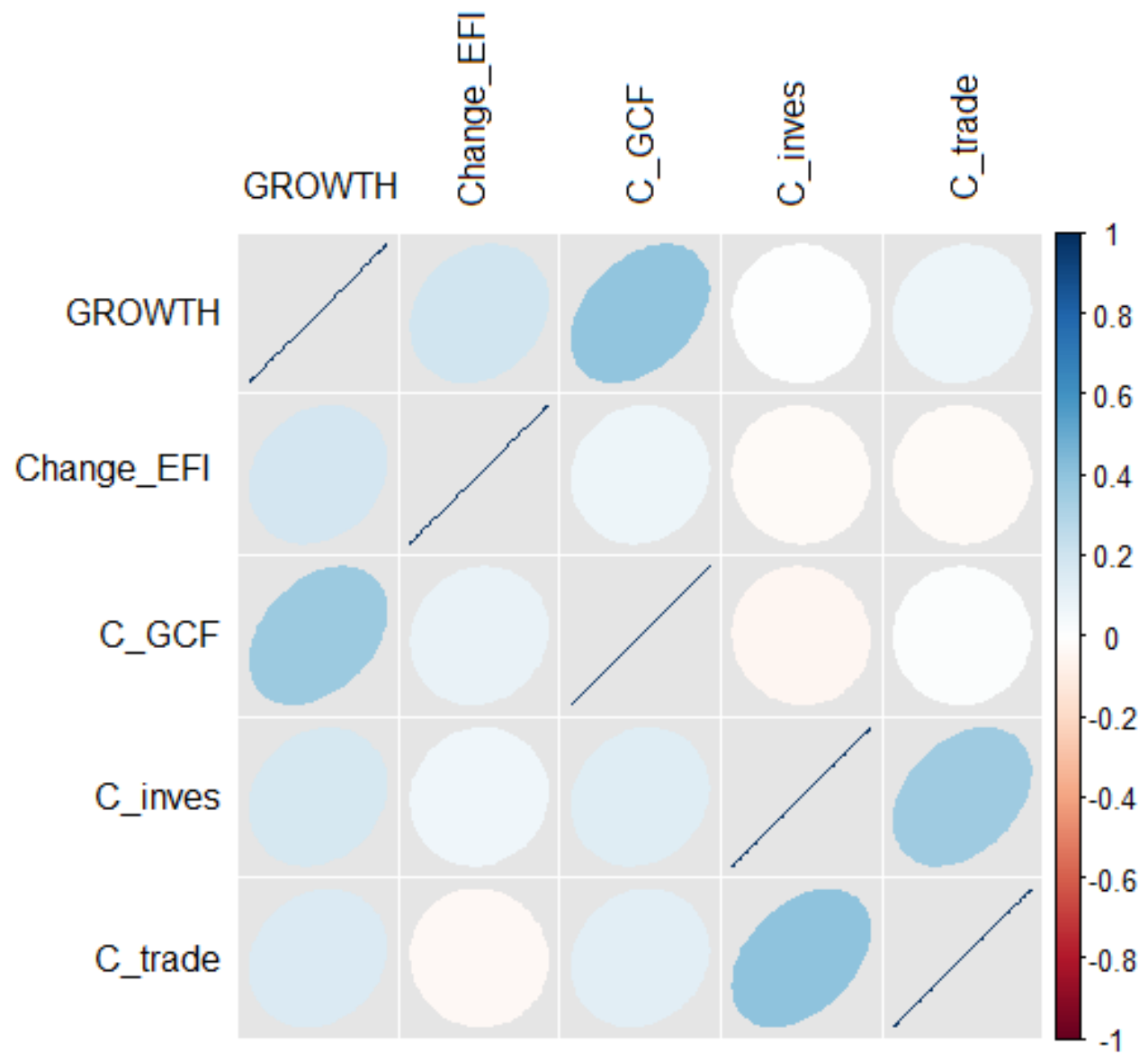

Source: Author.

Table 27. Correlation between variables of panel data

\begin{tabular}{|l|l|lllll|}
\hline \multicolumn{2}{|c|}{} & GROWTH & Change_EFI & C_GCF & C_inves & C_trade \\
\hline $\mathrm{r}$ & GROWTH & 1 & 0.195015 & 0.392047 & 0.000549 & 0.077037 \\
& Change_EFI & 0.185094 & 1 & 0.07635 & -0.02864 & -0.02583 \\
& C_GCF & 0.365831 & 0.096332 & 1 & -0.04097 & 0.015072 \\
& C_inves & 0.172403 & 0.063339 & 0.131556 & 1 & 0.359274 \\
& C_trade & 0.159992 & -0.03471 & 0.127574 & 0.408037 & 1 \\
\hline $\mathrm{p}$ & GROWTH & 1 & $<0.001$ & $<0.001$ & 0.988607 & 0.042181 \\
& Change_EFI & $<0.001$ & 1 & 0.04545 & 0.459519 & 0.499068 \\
& C_GCF & $<0.001$ & 0.01153 & 1 & 0.287068 & 0.69142 \\
& C_inves & $<0.001$ & 0.101663 & 0.0006 & 1 & $<0.001$ \\
& C_trade & $<0.001$ & 0.36373 & 0.000742 & $<0.001$ & 1 \\
\hline
\end{tabular}

Source: Author. 
Ivana Brkić

In the next segment, we will conduct a panel analysis. Results from the fixed effect model are presented in Table 28 and from the random effect model in Table 29.

Table 28. Fixed effects model - the impact of change of economic freedom on economic growth in the European Union countries

\begin{tabular}{|l|l|l|l|l|}
\hline \multicolumn{1}{|c|}{ Variable } & \multicolumn{1}{c|}{ Estimate } & \multicolumn{1}{c|}{ SE } & \multicolumn{1}{c|}{ t value } & \multicolumn{1}{c|}{$\mathrm{p}$} \\
\hline Change EFI & 0.149 & 0.042 & 3.502 & 0.0005 \\
\hline C_GCF & 0.328 & 0.03 & 10.24 & $<0.001$ \\
\hline C inves & 0.0006 & 0.004 & -0.168 & 0.867 \\
\hline C trade & 0.009 & 0.005 & 1.55 & 0.122 \\
\hline F-statistic: 30.14 on 4 and 636 DF, p-value: 0.000001 & $\mathrm{R}^{2}: 25.9 \%$ & Adjusted $\mathrm{R}^{2}: 21.8 \%$ \\
\hline
\end{tabular}

Source: Author.

Table 29. Random effects model - the impact of change of economic freedom on economic growth in the European Union countries

\begin{tabular}{|l|l|l|l|l|}
\multicolumn{1}{|c|}{ Variable } & \multicolumn{1}{c|}{ Estimate } & \multicolumn{1}{c|}{ SE } & \multicolumn{1}{c|}{ t value } & \multicolumn{1}{c|}{$\mathrm{p}$} \\
\hline Change EFI & 0.179 & 0.042 & 4.179 & $<0.001$ \\
\hline C_GCF & 0.308 & 0.028 & 10.69 & $<0.001$ \\
\hline C inves & 0.0007 & 0.004 & -0.168 & 0.865 \\
\hline C trade & 0.004 & 0.003 & 1.568 & 0.106 \\
\hline F-statistic: 138.6 on 4 and 636 DF, $p$-value: $<0.001$ & $\mathrm{R}^{2}: 27.3 \%$ & Adjusted $\mathrm{R}^{2}: 26.8 \%$ \\
\hline
\end{tabular}

Source: Author.

We used the Hausman test (or the test for endogeneity) in order to test whether the unique errors are correlated with the regressor. The results of comparison between the fixed model and the random model are as follows:

chisq $=32.066, \mathrm{df}=4, \mathrm{p}$-value $<0.0001$. The result indicates that we need to use fixed effect model for our data.

Assumptions:

1. We tested cross-sectional dependence using the Breusch-Pagan LM test of independence (Breusch \& Pagan, 1979, Hoechle, 2007). The null hypothesis in the B$\mathrm{P} / \mathrm{LM}$ test of independence is that residuals across entities are not correlated. B-P/LM and Pasaran CD (cross-sectional dependence) tests are used to test whether the 
residuals are correlated across entities. Result was shown chisq $=2520.6, \mathrm{df}=378, \mathrm{p}$ $<0.01$, so we can conclude that our model has cross-sectional dependence.

2. We tested serial correlation (autocorrelation) using the Breusch-Godfrey test. The null hypothesis of this test is that there is no serial correlation. Result was shown chisq $=$ 161.94, $\mathrm{df}=16, \mathrm{p}<0.01$. According to the result, there is a serial correlation.

3. We tested heteroskedasticity using the Breusch-Pagan test. The null hypothesis of this test is that there is homoskedasticity. The result was shown $\mathrm{BP}=5.813$, $\mathrm{df}=4$, $\mathrm{p}=0.2135$. According to the result, there is no heteroskedasticity.

4. We tested stationarity using the Dickey-Fuller test. The null hypothesis of this test is that the series is nonstationary. The result was shown for dependent variable Growth: Dickey-Fuller $=-10.826, \mathrm{p}=0.01$. According to the result, there are no unit roots. For independent variables: Change EFI : Dickey-Fuller $=-14.65$, Lag order $=2$, pvalue $=0.01$, C_GCF: Dickey-Fuller $=-3.25$, Lag order $=2$, p-value $=0.025$, C_inves: Dickey-Fuller $=-10.159$, Lag order $=2$, p-value $=0.01$ and C_trade: Dickey-Fuller $=-3.8492$, Lag order $=2, \mathrm{p}$-value $=0.01654$. According to the result, there are no unit roots present in independent variables.

The problem with cross-sectional dependence we solved by including time effects in our model. We tested statistical difference between fixed effects model without time effects and with time effects by $\mathrm{F}$ test for individual effects and obtained the following results $\mathrm{F}=$ 21.276 , df1 $=24$, df $2=612, \mathrm{p}<0.01$. According to this result, we can conclude that it is better to use time-fixed effects. The problem of autocorrelation was solved by using the robust covariance matrix estimator HAC (Andrews, 1991). In Table 30 we present final fixed effects model that shows the impact of change of economic freedom on economic growth in the European Union countries 
Table 30. Final fixed effects model - impact of change of economic freedom on economic growth in European Union countries

\begin{tabular}{|l|l|l|l|l|}
\multicolumn{1}{c|}{ Variable } & \multicolumn{1}{c|}{ Estimate } & \multicolumn{1}{c|}{ SE } & \multicolumn{1}{c|}{ t value } & \multicolumn{1}{c|}{$\mathrm{p}$} \\
\hline Change EFI & 0.092 & 0.038 & 2.396 & 0.017 \\
\hline C_gcf & 0.124 & 0.042 & 5.776 & $<0.001$ \\
\hline C inves & 0.002 & 0.003 & -0.071 & 0.923 \\
\hline C trade & 0.031 & 0.012 & 2.655 & 0.008 \\
\hline F-statistic: 27.443 on 4 and 612 DF, p-value: 0.000001 & $\mathrm{R}^{2}: 33.7 \%$ & Adjusted $\mathrm{R}^{2}: 32.8 \%$ \\
\hline
\end{tabular}

Source: Author.

Statistically significant independent variable is Change EFI ( $\mathrm{p}=0.017)$, independent variable C_GCF $(\mathrm{p}<0.001)$ and C_trade $(\mathrm{p}=0.008)$. It means that each 1 unit increase of Change Efi causes increase in Growth by 0.092; each 1 unit increase of C_gcf causes increase in Growth by 0.124 and also each 1 unit increase of $C$ trade causes increase in Growth by 0.031 . 


\subsection{CHAPTER SUMMARY}

Chapter 4 presents the results of an empirical study on determining the impact of economic freedom on economic growth. After the descriptive analysis of the dependent and independent variables, as well as the conducted correlation analysis, the second, third and fourth subchapters present the results of a panel analysis of the impact of economic freedom, its elements, as well as change of economic freedom on economic growth in the sample of European Union countries covering a period of twenty-five years. Prior to each analysis, appropriate tests were carried out which enabled the quality of the concrete panel analysis. The results are presented in graphs and tables.

The subsequent fifth chapter will discuss the results of the research based on the above analyses, which will confirm or challenge the hypotheses, we will compare the results with the views/results of other authors, as well as draw a general conclusion regarding the subject of the research. In the final part, we will give indications and directions for further research. 


\section{CHAPTER 5: DISCUSSION, CONCLUSIONS, LIMITATIONS AND FUTURE LINE OF RESEARCH}

\subsection{INTRODUCTION}

If we make a retrospective, we can see that the concept of the dissertation is logical and gradual. The introductory part discusses the justification of the research, sets the research goals, briefly constructs a theoretical perspective on the set problems, and presents the following structure of the dissertation. The second chapter of the dissertation is entirely devoted to the theoretical basis for subsequently conducted empirical research. It defines the basic concepts that are the subject of research in the dissertation and reviews the results of previous research available in the scientific literature on the relationship between economic freedom and economic growth. The empirical part contains the results of the research and focuses on testing the hypotheses.

Over the past decades, the notion of economic freedom has attracted considerable attention. Since the creation and publication of numerous indexes of economic freedom, the ability of researchers to draw conclusions about the impact of economic freedom on economic performance and other indicators of human well-being has increased. It can be said that two indicators that read the state of economic freedom in many countries are dominant and accepted: the Economic Freedom of the World Index (constructed by the Fraser Institute) and the Index of Economic Freedom (developed by the Heritage Foundation jointly with the Wall Street Journal), and that they similarly view phenomena that contribute to economic freedom in a positive/negative way (Kapás \& Czeglédi, 2007). In the numerous scientific literatures reviewed in the preceding chapters, answers to three questions were essentially sought: (1) What is the relationship between economic freedom and growth? (2) What is it that drives the given relation? (3) Which component of economic freedom contributes most to economic growth?. In scientific studies and empirical research, particular attention was paid to the dilemma of whether the level or change in the level of economic freedom is determinative regarding the impact on economic growth. Furthermore, what is equally present in the study of the relationship between economic freedom and growth is the examination of causality as well as effect. A significant number of authors have devoted 
themselves to decomposing one of the aforementioned indices and researching which aspect of economic freedom contributes most to improving economic performance. In this context, the tendency of the research conducted in the dissertation is to make a scientific contribution to the given topics and dilemmas, and to investigate the given relations on a sample of countries that is specific in its economic and political connotation.

The first three segments of this chapter analyze the results of the panel analysis conducted within the framework of the dissertation on the impact of economic freedom, elements of economic freedom, as well as change of economic freedom on economic growth in the EU countries, and at the same time confirm or refute the hypotheses. In the fourth part, a synthesis of all the considerations on the given topics is conducted and the overall conclusion of the whole research is given. Some limitations of the conducted research with special emphasis on the directions of further research inspired by the results obtained in the dissertation are presented in the last segment of the chapter.

\subsection{DISCUSSION OF THE RESULTS OF PANEL ANALYSIS ON THE IMPACT OF ECONOMIC FREEDOM ON ECONOMIC GROWTH IN THE EU COUNTRIES}

Based on the results of the research on the positive but not statistically significant impact of economic freedom on economic growth in EU countries, we conclude that General Hypothesis $1\left(\mathrm{H}_{0}\right)$ : Economic freedom has a positive impact on economic growth in $\mathrm{EU}$ countries - is REFUTED, whereas alternative hypothesis $\left(\mathrm{H}_{1}\right)$ holds: Economic freedom has a negative or no impact on economic growth in European Union countries.

It is not uncommon to obtain negative results. Similarly, conducting the research, De Haan \& Sturm (2000) and Sturm \& De Haan (2001) concluded that the overall level of economic freedom is not related to economic growth, while some of its elements and change of economic freedom are. In this direction and with the given idea, the continuation of research within this dissertation was done. Heckelman and Stroup (2000) also concluded that the overall level of economic freedom is not related to economic growth, while some elements are. By relating the level of economic freedom to the level of GDP (per capita) in a sample of selected EU member states, Kovačević \& Borović (2014) found a positive but not statistically significant relationship. The absence of statistical significance in the relationship 
between economic freedom and economic growth was also noted by Wu (2011) in his research. Dawson (2003) did not find a statistically significant relationship in examining the sampling of economic growth with economic freedom in the long run.

On the other hand, it is possible to obtain different results using different methods of quantitative analysis, as well as a different model specification in terms of changing control variables to prove the robustness of the results, which is the basis for future tests aimed at proving or refuting the findings in this dissertation. Likewise, it would be useful to examine whether the level of economic freedom in a given sample of countries affects other economic indicators (eg investment), as was proved in studies by Dawson (2003), Justesen (2008), Aixalá \& Fabro (2009) and thus indirectly economic growth.

\subsection{DISCUSSION OF THE RESULTS OF PANEL ANALYSIS ON THE IMPACT OF ELEMENTS OF ECONOMIC FREEDOM ON ECONOMIC GROWTH IN THE EU}

\section{COUNTRIES}

The results of the panel analysis on the impact of elements of economic freedom on economic growth in EU countries show that out of eight observed components of economic freedom (two variables were removed from the final model due to the issues with multicollinearity), two subindices had statistically significant impact on the dependent variable Economic growth, while six did not show such significance. Thus, Monetary Freedom has a positive impact on economic growth in the countries of the European Union in the sense that the growth of the Monetary Freedom subindex by one unit causes a percentage change in economic growth by 0.09 units. On the other hand, the growth of Investment Freedom by one unit leads to an economic decline by 0.056 units.

The results obtained indicate that "Certain aspects of economic freedom have a positive impact on economic growth in EU countries", hence Special Hypothesis $1\left(\mathrm{H}_{0}\right)$ is CONFIRMED.

Using individual hypotheses, it will be clearly defined which aspects of economic freedom have a positive impact and which negative, that is, which do not have any (statistically significant) impact on economic growth. 
As the first two indices were removed from the final model due to multicollinearity issues, neither Individual Hypothesis 1.1. $\left(\mathrm{H}_{0}\right)$-Property rights have a positive impact on economic growth in the countries of the European Union, nor Individual Hypothesis 1.2. $\left(\mathrm{H}_{0}\right)$ - Government Integrity has a positive impact on economic growth in European Union countries - can be confirmed or refuted.

Tax burden did not show a statistically significant impact on the dependent variable Economic Growth, hence Individual Hypothesis 1.3. $\left(\mathbf{H}_{0}\right)$-Tax burden has a positive impact on economic growth in EU countries - is REFUTED and alternative hypothesis $\left(\mathrm{H}_{1}\right)$ - Tax burden has a negative or no impact on economic growth in European Union countries is supported.

The panel analysis did not establish a positive, statistically significant relationship between the Public Expenditure aspect of the Index of Economic Freedom of the Heritage Foundation and economic growth in the sample of European Union countries, hence Individual Hypothesis 1.4. Public spending has a positive impact on economic growth in EU countries - is $\boldsymbol{R E J E C T E D}$, while the alternative hypothesis $\left(\mathrm{H}_{1}\right)$ - Public spending has a negative or no impact on economic growth in EU countries is confirmed.

Business freedom showed no statistically significant relationship with the dependent variable Economic growth in the European Union, hence Individual Hypothesis 1.5. Business freedom has a positive impact on economic growth in EU countries - is $\boldsymbol{R E F U T E D , ~ w h e r e a s ~ t h e ~ a l t e r n a t i v e ~ h y p o t h e s i s ~}\left(\mathrm{H}_{1}\right)$ - Business freedom has a negative or no impact on economic growth in EU countries is valid.

Aspect of economic freedom dedicated to labor market liberalization - Labor Freedom - did not, at this point, show statistically significant impacts on Economic Growth, hence Individual Hypothesis 1.6. Labor freedom has a positive impact on economic growth in EU countries - is REFUTED. As this aspect of economic freedom was formed within the Index of Economic Freedom of the Heritage Foundation only in later years, it is possible that the lack of the required amount of data contributed to this result. 
Monetary freedom showed a POSITIVE, STATISTICALLY SIGNIFICANT impact on Economic Growth within our analysis, hence Individual Hypothesis 1.7. Monetary freedom has a positive impact on economic growth in EU countries - is CONFIRMED.

A statistically significant relationship between the aspect of free trade and economic growth within the European region was not shown by the conducted research hence Individual Hypothesis 1.8. Trade freedom has a positive impact on economic growth in EU countries- is REFUTED.

Investment freedom showed a NEGATIVE STATISTICALLY SIGNIFICANT impact on the dependent variable Economic growth in the observed sample of countries, hence Individual Hypothesis 1.9 Investment freedom has a positive impact on economic growth in EU countries - is REFUTED.

Individual Hypothesis 1.10.Financial freedom has a positive impact on economic growth in EU countries - is REFUTED because the analysis did not establish a statistically significant impact of the economic freedom subindex - Financial freedom on the variable Economic growth.

The results obtained in the dissertation were compared with those obtained by authors who used the same (panel) or other method for the purpose of conducting their research (Table 58). Also, as no other study that covered the same sample of countries or the study period was conducted, the results obtained in the dissertation were compared with the results of other authors who investigated the impact of economic freedom on economic growth (or some other form of economic progress ${ }^{2}$ ) on different sample of countries, in the presence of the same or different control variables. As the theoretical part draws a parallel between the Index of Economic Freedom published by the Heritage Foundation and the Fraser Institute, the comparison of the results obtained in the dissertation with the results of other authors also used the findings obtained by other authors using the Fraser Institute's Index of Economic Freedom in investigating the impact of economic freedom on economic growth, which are presented in Table 58 in the so-called italic letters. Some of the research that was dealt with in the theoretical part of the dissertation was not covered by the comparison, either because of

\footnotetext{
${ }^{2}$ Akin et al. (2014)- GDP level; Alexandrakis and Livanis (2013) - GDP per worker; Cebula (2011); Cebula et al. (2013) GDP per capita;
} 
the lack of exact information in the research itself or for other objective reasons, that is, the inability of meaningful comparability of the results.

The results obtained in our study are specific to the selected sample of countries, observed over a defined period of time and processed based on one type of quantitative analysis. In this respect, neither can it be expected that they fully coincide with the results obtained from other authors, nor that the findings are consistent with the general scientific view. The conclusion to be drawn from the comparison is which aspect of economic freedom is equally important for the observed groups of countries, and what is characteristic of the sample of countries in our study. 
Table 31. Comparison of findings of the research on the impact of elements of economic freedom with those of other authors

\begin{tabular}{|c|c|c|c|}
\hline & POSITIVE & NEGATIVE & $\begin{array}{c}\text { NOT STATISTICALLY } \\
\text { SIGNIFICANT } \\
\end{array}$ \\
\hline PROPERTY RIGHTS & $\begin{array}{l}\text { Ahmadpour et al. (2013) - OPEC } \\
\text { Akin et al. (2014) } \\
\text { Alexandrakis and Livanis (2013) - Latin America and OECD } \\
\text { Carlsson and Lundström (2002) } \\
\text { Cebula and Mixon (2012) - OECD } \\
\text { Gorlach and Le Roux (2013) - SADC } \\
\text { Mahmood et al. (2010) - SAARC } \\
\text { Cebula (2011) - OECD } \\
\text { Cebula et al. (2013) - OECD }\end{array}$ & & $\begin{array}{l}\text { Justesen (2008) + } \\
\text { Kovačević and Borović (2014) }\end{array}$ \\
\hline $\begin{array}{l}\text { GOVERNMENT INTEGRITY / } \\
\text { FREEDOM FROM CORRUPTION }\end{array}$ & $\begin{array}{l}\text { Mahmood et al. (2010) - SAARC } \\
\text { Peev and Mueller (2012) - transition economies } \\
\text { Cebula (2011) - OECD } \\
\text { Cebula et al. (2013) - OECD }\end{array}$ & Tiwari (2011) - Asian countries & Kovačević and Borović (2014) \\
\hline TAX BURDEN/ FISCAL FREEDOM & $\begin{array}{l}\text { Cebula and Mixon (2012) - OECD } \\
\text { Kovačević and Borović (2014) } \\
\text { Rajasalu (2003) - EU } \\
\text { Tiwari (2011) - Asian countries } \\
\text { Cebula (2011) - OECD }\end{array}$ & Heckelman and Stroup (2000) & $\begin{array}{l}\text { Cebula, Clark and Mixon (2013) } \\
\text { Cebula et al. (2013) - OECD }\end{array}$ \\
\hline PUBLIC SPENDING & $\begin{array}{l}\text { Ahmadpour et al. (2013) - OPEC } \\
\text { Akin et al. (2014) - middle income level } \\
\text { Alexandrakis and Livanis (2013) - } \\
\text { Reduced public spending affects LA countries, but not OECD } \\
\text { Ayal and Karras (1998) } \\
\text { Cebula and Mixon (2012) - OECD } \\
\text { Cebula et al. (2013) - OECD } \\
\text { Gorlach and Le Roux (2013) - SADC } \\
\text { Heckelman and Stroup (2000) } \\
\text { Justesen (2008) } \\
\text { Kovačević and Borović (2014) }\end{array}$ & $\begin{array}{l}\text { Carlsson and Lundström (2002) } \\
\text { Mahmood et al. (2010) - SAARC }\end{array}$ & $\begin{array}{l}\text { Akin et al. (2014) - high and low } \\
\text { income }\end{array}$ \\
\hline BUSINESS FREEDOM & $\begin{array}{l}\text { Ahmadpour et al. (2013) - OPEC } \\
\text { Gorlach and Le Roux (2013) - SADC } \\
\text { Justesen (2008) } \\
\text { Mahmood et al. (2010) - SAARC } \\
\text { Cebula (2011) - OECD } \\
\text { Cebula et al. (2013) - OECD } \\
\end{array}$ & Kovačević and Borović (2014) & \\
\hline LABOR FREEDOM & $\begin{array}{l}\text { Ahmadpour et al. (2013) - OPEC } \\
\text { Gorlach and Le Roux (2013) - SADC } \\
\text { Justesen (2008) } \\
\text { Cebula (2011) - OECD }\end{array}$ & Kovačević and Borović (2014) & Cebula et al. (2013) - OECD (-) \\
\hline
\end{tabular}


The relationship between economic freedom and economic growth in EU countries Ivana Brkić

\begin{tabular}{|c|c|c|c|}
\hline MONETARY FREEDOM & $\begin{array}{l}\text { Ahmadpour et al. (2013) - OPEC } \\
\text { Akin et al. (2014) } \\
\text { Alexandrakis and Livanis (2013) - both groups of countries } \\
\text { Ayal and Karras (1998) } \\
\text { Gorlach and Le Roux (2013) - SADC } \\
\text { Peev and Mueller (2012) - transition economies } \\
\text { Rajasalu (2003) - EU } \\
\text { Cebula (2011) - OECD } \\
\text { Cebula et al. (2013) - OECD }\end{array}$ & Kovačević and Borović (2014) & $\begin{array}{l}\text { Carlsson and Lundström (2002) } \\
\text { Justesen (2008) + }\end{array}$ \\
\hline TRADE FREEDOM & $\begin{array}{l}\text { Akin et al. (2014) - with the decline in income } \\
\text { Alexandrakis and Livanis (2013) in OECD } \\
\text { Ayal and Karras (1998) } \\
\text { Cebula and Mixon (2012) - OECD } \\
\text { Gorlach and Le Roux (2013) - SADC } \\
\text { Kovačević and Borović (2014) } \\
\text { Mahmood et al. (2010) - SAARC } \\
\text { Peev and Mueller (2012) - transition economies } \\
\text { Cebula et al. (2013) - OECD }\end{array}$ & $\begin{array}{l}\text { Ahmadpour et al. (2013) - OPEC } \\
\text { Akin et al. (2014) - high income } \\
\text { Alexandrakis and Livanis (2013)- } \\
\text { in LA } \\
\quad \text { Carlsson and Lundström } \\
\quad \text { (2002) }\end{array}$ & Justesen (2008) + \\
\hline INVESTMENT FREEDOM & $\begin{array}{l}\text { Kovačević and Borović (2014) } \\
\text { Mahmood et al. (2010) - SAARC } \\
\text { Rajasalu (2003) - EU } \\
\text { Cebula (2011) - OECD } \\
\text { Cebula et al. (2013) - OECD }\end{array}$ & & \\
\hline FINANCIAL FREEDOM & $\begin{array}{l}\text { Ahmadpour et al. (2013) - OPEC } \\
\text { Ayal and Karras (1998) } \\
\text { Carlsson and Lundström (2002) } \\
\text { Gorlach and Le Roux (2013) - SADC } \\
\text { Justesen (2008) } \\
\text { Kovačević and Borović (2014) } \\
\text { Mahmood et al. (2010) - SAARC } \\
\text { Tiwari (2011) - Asian countries }\end{array}$ & & Cebula et al. (2013) - OECD (-) \\
\hline
\end{tabular}

Source: Author. 
Ivana Brkić

Based on the comparison of the results of our research, which are shaded in Table 58, most coincidence with the results of other authors is observed in the Monetary freedom subindex. We conclude that the given aspect of economic freedom is equally significant and common to most regions or groups of countries that were the subject of different surveys, and that other aspects have more or less impact in specific groupings of countries.

As monetary freedom actually implies price stability, i.e. the absence of inflation but also price control by the state (which necessarily leads to the emergence of market surpluses and/or shortage), we conclude that this aspect of economic freedom is crucial for economic prosperity and free market. Price stability and its role in achieving economic growth and development, that is, the negative impact of inflation on economic progress, has been confirmed in numerous theoretical and empirical literature (Fischer, 1993; Barro, 1995; Gomme, 1993; Gylfason \& Herbertsson, 2001). In order to achieve this objective, the European Union is striving to form a monetary union of all Member States and to implement a single monetary policy by the European Central Bank. Although there are conflicting opinions about the justification for the existence of European Monetary Union (eg Soros, 1996; Jossa, 1996; Dornbusch, 1996), our research supports the benefits provided by such an economic space. However, we emphasize that the above conclusions about the impact of monetary freedom on economic growth are relevant solely in the context of all other elements of economic freedom, as well as other traditional macroeconomic factors in the model. In other words, our study did not establish a correlation between economic growth and monetary freedom in a selected sample of countries when looking at their direct relationship, that is, only in the panel analysis conducted, in the presence of all other factors that ensure the existence of economic freedom in general, as well as factors important for economic growth, this aspect contributes to economic prosperity.

A negative sign is recorded in the relationship between Investment freedom and economic growth. Such a sign does not mean that investments reflect negatively on GDP growth, but what constitutes Investment freedom, according to the view of the Heritage Foundation, contributes negatively to economic growth in a selected sample of countries. Not only is equal treatment of foreign and domestic investments often present, but foreign investors get higher benefits than domestic ones. This creates large expenditures in the budget for the purpose of 
Ivana Brkić

attracting foreign investors (subsidizing jobs, etc.), which can neutralize or surpass the positive effects of foreign investment on economic growth. The fact is that foreign capital looks for low costs, which means exploitation of labor and natural resources in countries where laws are not clearly defined in order to protect them, which also has negative effects on the economic situation of the host country. It is also the practice that most foreign capital transfers its profits made in the country to its parent companies, thus eliminating the most significant contribution to economic growth.

Other components of economic freedom in the sample of observed countries did not show statistically significant results on the examined link with economic growth. These results were also reported by some of the other authors shown in Table 31. The robustness of the results obtained should be tested using a different research method and/or in the presence of other control variables, which is planned for future research.

\subsection{DISCUSSION OF THE RESULTS OF PANEL ANALYSIS ON THE IMPACT OF CHANGE OF ECONOMIC FREEDOM ON ECONOMIC GROWTH IN THE EU COUNTRIES}

According to the results of the survey, it was shown that a change of economic freedom has a statistically significant impact on economic growth in EU countries. With this knowledge, General Hypothesis 2 - Change of economic freedom has a positive impact on economic growth in EU countries - is CONFIRMED.

Although numerous studies have proved the positive impact of the level of economic freedom on economic growth (most notable among them being Carlsson and Lundström (2002), Cole (2003), Justesen (2008) and others), the results of the research that show that change of the level of economic freedom is significantly related to growth (while the level is not) have also been noted. Among the most relevant authors who have presented such scientific contributions are De Haan \& Siermann (1998), Gwartney, Lawson \& Holcombe (1999), De Haan \& Sturm (2000, 2001), Pitlik (2002) and Sturm et al. (2002), Doucouliagos \& Ulubasoglu (2006), Aixalá \& Fabro (2009), Adkins et al. (2002) and Wu (2011). 
Ivana Brkić

What may be one of the explanations of the results obtained is that both sizes are of dynamic character (as opposed to comparing the relation between the level of economic freedom and change - economic growth), and that based on that the recognized relationship is a linear, statistically significant, positive relationship. In future research, the aim is to validate the results obtained by constructing a different one and to establish the robustness of the results obtained. We can also agree with the views of other authors who have come to the conclusion that earlier changes have significant effects on the growth rate precisely due to the fact that it takes some time for changes in institutional structures to lead to changes in economic indicators (Gwartney at all. 1999; Gwartney \& Lawson, 2004).

\subsection{MAIN CONCLUSIONS OF THE RESEARCH}

In the context of survival on the world market, the European Union needs to find an economic model that will keep it competitive. The European standard of living expressed as a per capita gross domestic product is still lower than that of the United States (Balcerowicz, Łaszk, Rzońca \& Kalina, 2013). The Chinese economy has been experiencing explosive growth over the last three decades. The global economic crisis, the rising unemployment rates, the "euro crisis", migration, Brexit, are all challenges the European Union must find the answer to and take appropriate action. Although there is no social consensus as to which direction and which instruments should be used to address these issues, in the dissertation we have asked whether economic freedom is a factor that can stimulate growth and development of an economy in a particular geo-economic area - specifically the European Union as well as whether the indicator of the presence of economic freedom is also an indicator of economic progress of a particular area. The research was conducted in order to determine whether policies and institutions that favor and promote economic freedom have justification and evidence for that on the example of economic growth. Specifically, in the dissertation we addressed the question of whether economic freedom and exactly which of its components affect the enlargement of the European Union economy, providing empirical evidence through a panel analysis, looking at data on economic freedom and economic growth over the past twenty-five years (from 1994 to 2018). For this purpose, the dissertation uses an indicator of economic freedom, created by the Heritage Foundation, which publishes a report on the state of economic freedom in the world every year 
Ivana Brkić

in collaboration with the Wall Street Journal. Their index is made up of ten (or twelve) equal components that make up the global index. Elements of economic freedom observe the protection of property rights within individual countries, the presence of corruption in all sectors of society, the size of public spending, the tax burden on the economy and citizens, ease of doing business in the country concerned, as well as flexibility in the labor market, price stability, international trade, the presence of foreign investment, development of financial markets and many other parameters of economic liberalism of the categories described.

Numerous studies have dealt with this and related matter, that is, identifying economic freedom as a factor of economic growth. Although many of the authors of these studies have come to the conclusion that all or some forms of economic freedom have a stake in stimulating economic growth and/or other parameters of economic progress, such views are not unified. In this respect, we wanted to contribute to science and investigate whether and what components of economic freedom represent, cause and/or influence economic progress.

Consistent with the current knowledge on this topic presented within the theoretical part of the dissertation, we have found that the level of economic freedom is not, but that the change in the level is an indicator of economic growth, and thus confirmed certain hypotheses raised in the dissertation. Yet, no study is capable of resolving theoretical debates on a topic, nor can it in itself provide compelling empirical evidence on research questions. Thus, the obtained evidence in our research should be interpreted taking into account the sample, methods and availability of data, which may have influenced the results obtained.

The panel analysis proved the positive impact of the change of economic freedom on economic growth in the countries of the European Union, thus confirming general hypothesis 2. The panel model identified those and elements of economic freedom that contribute most to economic growth (which confirmed special hypothesis 1). This primarily refers to the element of Monetary freedom. However, this aspect of economic freedom showed the given influence only in the context/presence of all other elements of economic freedom. Since economic freedom is a comprehensive indicator, as a display of the synergy of all its constituent elements, the importance in macroeconomic policy making must be attributed to other categories as well. The 
Ivana Brkić

efficiency of the justice system forms the platform of every regulated society. It is crucial for the functioning of the economy because it enables the protection of basic property rights as the foundation of capitalist society. If private property is secured from all forms of abuse, individuals have interests and motives to fight for their property and make a profit on that basis, thus causing economic growth. Heavy bureaucracy and extensive procedures in all aspects of business are a source of corruption. They stifle the entrepreneurial spirit, curb business ventures and risks, and dull the economy. The ease of doing business is also reflected in the labor market. Effective management of public finances and fiscal discipline is a compulsory task for the creators and implementers of economic policy of governments of all EU countries. Trade freedom had to find a place in the factors that explain economic growth. The very membership in the European Union implies the existence of a customs union and ensures the existence of free trade. Money creates money, so the imperative of economic growth in the EU is Financial freedom embodied in a diversified financial market, with a myriad of models and tools to finance business opportunities. Without fiscal discipline, there is no rational public spending, without the rule of law and the ease of conducting business processes, it is impossible to make and realize investments, and price stability, formed by the market, is an attribute of any economically sound society.

Regardless of the specification of the model, the control variables show the expected results in the sense that Gross capital formation has a positive, statistically significant impact on economic growth, as well as the aspect of Trade (\% of GDP). Surprisingly, foreign direct investment did not document the significance to growth in our sample of countries, although there is research to substantiate these results (e.g. Ericsson \& Irandoust, 2001; Azman-Saini, Baharumshah \& Law, 2010).

Finally, we conclude that economic freedom does not show statistical significance in relation to economic growth (percentage change in GDP per capita) in EU countries, but that change of economic freedom does have impact, thus concluding that economic liberalization, as the main motive and goal of the European Union as a political - economic community, serves to achieve better economic well - being of its population and that the macroeconomic course should be pursued in that direction. In addition to the above, it is important to point out that the aspect of 
Ivana Brkić

Monetary freedom, like in numerous other studies, has a significant positive impact on economic growth in our sample of countries, and that achieving price stability and the absence of inflation as well as price control (through the formation of a monetary union of all EU Member States) is recommended if economic progress is to be made.

Although all of these results represent an original contribution to science and practice, as they are among the first to show the relationship between economic freedom and economic growth within the European Union, their interpretation should take into account the fact that they cannot be applied universally or in every Member State of the European Union.

Economic freedom implies perfection for it to exist. As part of the research, we tried to determine if it is also a way to achieve a prototype of general economic well-being. We have explored the question of whether economic freedom is an ideology that favors economic growth, or there is real evidence to propagate it. On the basis of all the above, we believe that the decision on economic liberalization as opposed to state intervention should not be exclusive. Dogma for or against state intervention versus economic freedom is not appropriate. Ideal economic governance should not be judged based on the level of the presence of state intervention, but on the basis of its effectiveness reflected in economic prosperity and growth in the quality of life of all individuals. The decision on whether to "liberate" the market or place things under the patronage of the state should be made on the basis of the universal well-being of all citizens, which is reflected not only in economic growth but also in other parameters of social well-being, which will be the focus of the author's attention in future research.

\subsection{LIMITATIONS AND FUTURE LINE OF RESEARCH}

The results obtained in the dissertation are certainly significant, but they also raise new questions that need to be raised and dilemmas that need to be addressed in future research. According to the conclusions in the dissertation, the following areas of study are suggested for further research: 
Ivana Brkić

In order to determine the value of the results obtained in this research, it is necessary to repeat the study on the same sample after a certain period of time, and include a longer period of time and to make comparisons in order to establish or refute the consistency of the observed relationships.

It is recommended to carry out the same research (with the same time period and sample of countries) but with the help of other quantitative methods of analysis, and to compare and determine the robustness of the results obtained.

It would be important to analyze the same characteristics (sample, period, method) but apply different control variables, or perform a different specification of the model.

It is also of interest to investigate the link between economic freedom and economic growth within clusters within EU countries.

It would be useful to repeat the research using another leading indicator of economic freedom produced by the Fraser Institute and, on that basis, to test the hypotheses given and confirmed/refuted in this dissertation.

As the subject of the research was to determine the relationship between economic freedom and the economic progress of the European Union, it would be advantageous to examine such relations within other economic and political groups of countries. Based on the obtained results, it would be possible to find similarities and differences between these regions, and to identify which area with its specificities is most determined by economic freedom and its impact on economic growth.

Since numerous studies have dealt with the analysis of the impact of economic freedom on economic inequality across different country samples (Scully, 2002; Madan, 2002; Graeff \& Mehlkop, 2006; Carter, 2007; Ashby \& Sobel, 2008; Bergh \& Nilsson, 2008). 2010; Bennett \& Vedder, 2012; Apergis, Dincer \& Payne, 2014; Pérez-Moreno \& Angulo-Guerrero, 2016; Bennett \& Nikolaev, 2016), it would be advisable to do the same 
Ivana Brkić

research on a sample of European Union countries, or on its particular cluster and to compare the results with the findings from the above studies.

Many studies have addressed the relationship and impact of economic freedom on other macroeconomic indicators - investment (among others Dawson, 2003; Justesen, 2008; Aixalá \& Fabro, 2009; Ali \& Crain, 2001; Bengoa \& Sanchez-Robles, 2003; Nasir \& Hassan, 2011), productivity (e.g., Pääkkönen, 2009; Alexandrakis \& Livanis, 2013; Erdal \& Yenipazarli, 2013), GDP level (Islam, 1996; Akin et al., 2014; Cebula, 2011, 2013; Cebula et al., 2013; Cebula \& Clark, 2014; N'Zue, 2010; Gorlach \& Le Roux, 2013; Ossono, 2012; Haydaroglu, 2016; Türedi, 2013), unemployment (Grubel, 1998; Bennett, 2016) and others. Accordingly, it is important to perform analysis of the given relations on the sample of the countries of the European Union or its selected area, in the future modeled on the studies mentioned above.

Some authors have put economic freedom in relation to other indices - the Human Development Index (Madan, 2002; Grubel; 1998; Vukotić \& Baćović, 2006, and others), the Lifetime Index (Esposto \& Zaleski, 1999; Madan, 2002; Norton. 2003), the Poverty Index (Norton, 2003) and others. The suggestion for the future research is to determine the relationships between the Index of Economic Freedom of the Heritage Foundation with these and other indices that measure human and social development within the EU Member States.

The most important research for Spain, as well as the makers of its macroeconomic policy, would be to identify the elements of economic freedom that contribute to Spain's economic growth and development as a member state of the European Union. 
Ivana Brkić

\section{REFERENCES}

1. Acemoglu, D., Johnson, S., \& Robinson, J. A. (2001). The Colonial Origins of Comparative Development: An Empirical Investigation. The American Economic Review 91(5), 13691401 .

2. Acemoglu, D., Johnson, S., \& Robinson, J. A. (2002). Reversal of fortune: Geography and institutions in the making of the modern world income distribution. The Quarterly journal of economics, 117(4), 1231-1294.

3. Acemoglu, D., Johnson, S. \& Robinson, J.A. (2005). Institutions as the Fundamental Cause of Long-Run Growth. In Philippe Aghion and Steven N. Durlauf, eds, Handbook of Economic Growth: Volume Ia (Elsevier): 385-472.

4. Ahmadpour, M., JafariSamimi, A. \& Refaei, P. (2013). Economic freedom and economic growth: the case of OPEC. Journal of Human and Social Science Research. 1(1), 63-71.

5. Aixalá, J., \& Fabro, G. (2009). Economic freedom, civil liberties, political rights and growth: a causality analysis. Spanish Economic Review, 11(3), 165-178.

6. Akin, C. S., Aytun, C., \& Aktakas, B. G. (2014). The impact of economic freedom upon economic growth: an application on different income groups. Asian Economic and Financial Review, 4(8), 1024 -1039.

7. Alexandrakis, C., \& Livanis, G. (2013). Economic Freedom and Economic Performance in Latin America: A Panel Data Analysis. Review of Development Economics, 17(1), 34-48.

8. Ali, A. M., \& Crain, W. M. (2002). Institutional distortions, economic freedom, and growth. The Cato Journal, 21(3), 415-427.

9. Altay, A. P. D. H., \& Çelebioğlu, A. P. D. F. (2011). Spatial Analysis of Relations Among Democracy, Economic Freedom and Economik Growth: A Research On The European Countries. Süleyman Demirel Üniversitesi İktisadi ve İdari Bilimler Fakültesi Dergisi, 16(2), 199-234.

10. Andrews, D. W. K. (1991). Heteroskedasticity and Autocorrelation Consistent Covariance Matrix Estimation. Econometrica, 59(3), 817-858.

11. Ang, J.B. (2010). Finance and inequality: the case of India. South Econ J 76(3): 738-761. 
Ivana Brkić

12. Apergis, N., Dincer, O., \& Payne, J. E. (2014). Economic freedom and income inequality revisited: Evidence from a panel error correction model. Contemporary Economic Policy, $32(1), 67-75$.

13. Armey, R. K. (1995). The Freedom Revolution: The New Republican House Majority Leader Tells Why Big Government Failed, Why Freedom Works, and How We Will Rebuild America. Washington: Regnery Publishing.

14. Ashby, N. J., \& Sobel, R. S. (2008). Income inequality and economic freedom in the US states. Public Choice, 134(3-4), 329-346.

15. Ayal, E. B., \& Karras, G. (1998). Components of economic freedom and growth: an empirical study. The Journal of Developing Areas, 32(3), 327-338.

16. Azman-Saini, W. N. W., Baharumshah, A. Z., \& Law, S. H. (2010). Foreign direct investment, economic freedom and economic growth: International evidence. Economic Modelling, 27(5), 1079-1089.

17. Balcerowicz, L., Łaszk, A., Rzońca, A., \& Kalina, L. (2013). Economic growth in the European Union. Brussels: Lisbon Council.

18. Barro, R. J. (1991). Economic growth in a cross section of countries. Quarterly Journal of Economics, 106(2), 407-443.

19. Barro, R. J. (1996). Democracy and growth. Journal of economic growth, 1(1), 1-27.

20. Barro, R. J. (1995). Inflation and economic growth (NBER Working Paper No:5326), Cambridge MA, National Bureau of Economic Research.

21. Bayar, Y. (2016). Impact of Openness and Economic Freedom on Economic Growth in the Transition Economies of the European Union. South-Eastern Europe Journal of Economics, 14(1), 7-19.

22. Bayar, Y., \& Aytemiz, L. (2015). Impact of economic freedom, political stability and economic growth in the USA on emerging Asian economies. Actual problems of economics, 6 (168), 62-73.

23. Bengoa, M., \& Sanchez-Robles, B. (2003). Foreign direct investment, economic freedom and growth: new evidence from Latin America. European journal of political economy, 19(3), 529-545.

24. Bennet, D. L. (2016). Subnational Economic Freedom and Performance in the United States and Canada. Cato Journal, 36(1), 165-185. 
Ivana Brkić

25. Bennett, D. L., \& Nikolaev, B. (2017). On the ambiguous economic freedom-inequality relationship. Empirical Economics, 53(2), 717-754.

26. Bennett, D. L., \& Vedder, R. K. (2013). A dynamic analysis of economic freedom and income inequality in the 50 US states: Empirical evidence of a parabolic relationship. Journal of Regional Analysis \& Policy, 43(1), 42-55.

27. Bergh, A., \& Nilsson, T. (2010). Do liberalization and globalization increase income inequality?. European Journal of political economy, 26(4), 488-505.

28. Berlin, I. (1992). Dva koncepta svobode. In Rosanvallon Pierre, (ed.): Zbornik sodobni liberalizem, Ljubljana: Studia Humanitatis, 69-89.

29. Besley, T. (1995). Property rights and investment incentives: Theory and evidence from Ghana. Journal of political Economy, 103(5), 903-937.

30. Best, H., \& Wolf, C. (2015). The Sage handbook of regression analysis and causal inference.

31. Borović, Z. (2014, b). Does economic freedom impact economic growth: Evidence from two Western Balkan countries. Industrija, 42(2), 57-70.

32. Borović, Z. (2014, a). Does Economic Freedom impact Economic growth: Decomposing the Effects for Bosnia and Herzegovina. Acta Economica, 12 (21), 9-20.

33. Breusch, T. S. \& Pagan, A. R. (1979). A simple test for heteroscedasticity and random coefficient variation. Econometrica: Journal of the Econometric Society, 1287-1294.

34. Carlsson, F., \& Lundström, S. (2002). Economic freedom and growth: Decomposing the effects. Public choice, 112 (3-4), 335-344.

35. Carter, J. R. (2007). An empirical note on economic freedom and income inequality. Public Choice, 130(1-2), 163-177.

36. Cass, D. (1965). Optimum growth in an aggregative model of capital accumulation. The Review of economic studies, 32(3), 233-240.

37. Cebula, R. J. (2011). Economic growth, ten forms of economic freedom, and political stability: An empirical study using panel data, 2003-2007. Journal of Private Enterprise, $26(2), 61-81$.

38. Cebula, R. J. (2013). Which economic freedoms influence per capita real income?. Applied Economics Letters, 20(4), 368-372. 
Ivana Brkić

39. Cebula, R. J., \& Clark, J. R. (2014). The effects of economic freedom, regulatory quality and taxation on the level of per capita real income: a preliminary analysis for OECD nations and non-G8 OECD nations. Applied Economics, 46(31), 3836-3848.

40. Cebula, R. J., \& Mixon Jr, F. G. (2012). The impact of fiscal and other economic freedoms on economic growth: An empirical analysis. International Advances in Economic Research, 18(2), 139-149.

41. Cebula, R. J., \& Mixon, F. G. (2014). The roles of economic freedom and regulatory quality in creating a favorable environment for investment in energy $R \& D$, infrastructure, and capacity. American Journal of Economics and Sociology, 73(2), 299-324.

42. Cebula, R. J., Clark, J. R., \& Mixon Jr, F. G. (2013). The Impact of Economic Freedom on Per Capita Real GDP: A Study of OECD Nations. Journal of Regional Analysis and Policy, 43(1100-2016-90109), 34-41.

43. Chu, Y. P., \& Kong, T. Y. (2009). The impact of the political liberalization-economic freedom nexus on economic growth, 1970-2000. Applied Econometrics and International Development, 9(2), 21-30.

44. Clark, B. S. (1998). Political Economy: A Comparative Approach. Greenwood Publishing Group.

45. Cole, J. H. (2003). The contribution of economic freedom to world economic growth, 198099. The Cato Journal, 23(2), 189-199.

46. Cole, J. H., \& Lawson, R. A. (2007). Handling economic freedom in growth regressions: Suggestions for clarification. Econ Journal Watch, 4(1), 71-78.

47. Compton, R. A., Giedeman, D. C., \& Hoover, G. A. (2011). Panel evidence on economic freedom and growth in the United States. European Journal of Political Economy, 27(3), 423-435.

48. Dawson, J. W. (1998). Institutions, Investment, and Growth: New Cross-country and Panel Data Evidence. Economic inquiry, 36(4), 603-619.

49. Dawson, J.W. (2003). Causality in the freedom-growth relationship. European Journal of Political Economy, 19(3), 479-495.

50. De Haan, J. (2003). Economic freedom: editor's introduction. European Journal of Political Economy, 19(3), 395-403. 
Ivana Brkić

51. De Haan, J., \& Siermann, C. L. (1998). Further evidence on the relationship between economic freedom and economic growth. Public choice, 95(3-4), 363-380.

52. De Haan, J., \& Sturm, J. E. (2000). On the relationship between economic freedom and economic growth. European Journal of Political Economy, 16(2), 215-241.

53. De Haan, J., \& Sturm, J. E. (2006). How to handle economic freedom: Reply to Lawson. Econ Journal Watch, 3(3), 407-411.

54. De Haan, J., \& Sturm, J. E. (2007). Handling economic freedom in growth regressions: A reply to Cole and Lawson. Economic Journal Watch, 4(1), 79-82.

55. De Haan, J., \& Sturm, J.E. (2003). Does more democracy lead to greater economic freedom? New evidence for developing countries. European Journal of Political Economy, 19(3), $547-563$.

56. De Haan, J., Lundström, S., \& Sturm, J. E. (2006). Market-oriented institutions and policies and economic growth: A critical survey. Journal of Economic Surveys, 20(2), 157-191.

57. Diamond, J. (1997). Guns, Germs, and Steel. New York: W.W. Norton.

58. Dornbusch, R. (1996). Euro fantasies. Foreign Affairs, 75(5), 110-124.

59. Doucouliagos, C. (2005). Publication bias in the economic freedom and economic growth literature. Journal of Economic Surveys, 19(3), 367-387.

60. Doucouliagos, C., \& Ulubasoglu, M. A. (2006). Economic freedom and economic growth: Does specification make a difference?. European Journal of Political Economy, 22 (1), 6081.

61. Easton, S. T., \& Walker, M. (1992). Rating global economic freedom. Vancouver: The Fraser Institute.

62. Erdal, F. (2004). Economic Freedom and Economic Growth: A time series evidence from Italian economy. Available at: https://www.etsg.org/ETSG2004/Papers/erdal.pdf [04.06.2019.].

63. Erdal, F., \& Yenipazarli, A. (2013). Which economic freedoms contribute income per capita? Are results sensitive to the indicators and the estimation methods?. Emerging Markets Finance and Trade, 49(5), 130-147.

64. Ericsson, J. \& Irandoust, J. E. M. (2001). On the causality between foreign direct investment and output: a comparative study. The International Trade Journal, 15(1), 1-26. 
Ivana Brkić

65. Esposto, A. G., \& Zaleski, P. A. (1999). Economic freedom and the quality of life: an empirical analysis. Constitutional political economy, 10(2), 185-197.

66. Farr, W., Lord, R. A., \& Wolfenbarger, J. L. (1998). Economic freedom, political freedom, and economic well-being: a causality analysis. Cato Journal, 18(2), 247- 262.

67. Fischer, S. (1993). The role of macroeconomic factors in growth. Journal of monetary economics, 32(3), 485-512.

68. Friedman, M. (1962). Capitalism and freedom. University of Chicago press.

69. Friedman, M. (1988). A Statistical Note on the Gastil-Wright Survey of Freedom. In M.A. Walker (ed.) Freedom, Democracy and Economic Welfare. Vancouver: The Fraser Institute.

70. Friedman, M., Friedman R. (1980). Free to choose. Harcourt, San Diego, California, USA.

71. Frye, T., \& Shleifer, A. (1996). The invisible hand and the grabbing hand (No. w5856). National Bureau of Economic Research.

72. Gallup, J. L., Sachs, J. D., \& Mellinger, A. D. (1999). Geography and economic development. International regional science review, 22(2), 179-232.

73. Gangl, M. (2010). Causal Inference in Sociological Research. Annual Review of Sociology, $36,21-47$.

74. Gastil, R.D. (1984). Freedom in the World: Political Rights and Civil Liberties, 1983-1984. New York: Freedom House.

75. Gomme, P. (1993). Money and growth revisited: Measuring the costs of inflation in an endogenous growth model. Journal of Monetary economics, 32(1), 51-77.

76. Gorlach, V. (2011). An econometric analysis of the impact of economic freedom on economic growth in the SADC. Doctoral dissertation, Sciences of the Nelson Mandela Metropolitan University.

77. Gorlach, V. I., \& Le Roux, P. (2015) The impact of economic freedom on economic growth in the SADC: an individual component analysis. Studies in Economics and Econometrics, 39(2), 41-61.

78. Graeff, P., \& Mehlkop, G. (2006). Excavating a Force that Drives Income InequalityRethinking and Analyzing the Link between Military Participation Ratio and Inequality. Journal of Political and Military Sociology, 34(2), 257-279.

79. Granger, C. W. (1969). Investigating causal relations by econometric models and crossspectral methods. Econometrica: Journal of the Econometric Society, 37(3), 424-438. 
Ivana Brkić

80. Greene, W. H. (2008). Econometric Analysis, 6th ed. Upper Saddle River, NJ: Prentice Hall.

81. Grubel, H. (1998). Economic freedom and human welfare: Some empirical evidence. Cato Journal, 18(2), 287-304.

82. Gwartney, J. \& Lawson, R. (2001). Economic Freedom of theWorld: 2001 Annual Report. Vancouver: The Fraser Institute.

83. Gwartney, J. \& Lawson, R. (2004). Economic Freedom of the World. Annual Report 2004. Vancouver: The Fraser Institute.

84. Gwartney, J. \& Lawson, R. (2007). Economic Freedom of theWorld: 2007 Annual Report. Vancouver: The Fraser Institute.

85. Gwartney, J. \& Lawson, R., Hall, J. (2012). Economic freedom of the world 2012 annual report. Vancouver: The Fraser Institute.

86. Gwartney, J. Hall, J. \& Lawson. (2010). Economic freedom of the world 2010 annual report. Vancouver: The Fraser Institute..

87. Gwartney, J., Holcombe, R. G., \& Lawson, R. A. (2004). Economic freedom, institutional quality, and cross-country differences in income and growth. Cato Journal, 24, 205-233.

88. Gwartney, J., Holcombe, R. G., \& Lawson, R. A. (2006). Institutions and the Impact of Investment on Growth. Kyklos, 59(2), 255-273.

89. Gwartney, J., Lawson R. \& Samida, D. (2000). Economic Freedom of the World: 2000 Annual Report. Vancouver: The Fraser Institute.

90. Gwartney, J., Lawson, R. A., \& Holcombe, R. G. (1999). Economic Freedom and the Environment for Economic Growth. Journal of Institutional and Theoretical Economics (JITE), 155(4), 643-643.

91. Gwartney, J., Lawson, R., \& Block, W. (1996). Economic freedom of the world, 1975-1995. Vancouver: The Fraser Institute.

92. Gwartney, J., Lawson, R., \& Hall, J. (2015). 2015 Economic Freedom Dataset, published in Economic Freedom of the World: 2015 Annual Report. Vancouver: The Fraser Institute.

93. Gwartney, J., Lawson, R., \& Norton, S. (2008). Economic freedom of the world 2008 annual report. Vancouver: The Fraser Institute.

94. Gylfason, T., \& Herbertsson, T. T. (2001). Does inflation matter for growth?. Japan and the world economy, 13(4), 405-428. 
Ivana Brkić

95. Hall, J. C., \& Lawson, R. A. (2014). Economic freedom of the world: An accounting of the literature. Contemporary Economic Policy, 32(1), 1-19.

96. Hall, J., Lawson, R., \& Wogsland, R. (2011). The European Union and economic freedom. Global Economy Journal, 11(3), 1-14.

97. Hall, R. E., \& Jones, C. I. (1997). Levels of Economic Activity Across Countries. American Economic Review 87 (2), 173-77.

98. Hall, R. E., \& Jones, C. I. (1999). Why do some countries produce so much more output per worker than others?. The quarterly journal of economics, 114(1), 83-116.

99. Hanke, S. H., \& Walters, S. J. (1997). Economic freedom, prosperity, and equality: A survey. Cato Journal, 17(2), 117-146.

100. Haydaroglu, C. (2016). The Effect of Foreign Direct Investment and Economic Freedom on Economic Growth: The Case of BRICS Countries. Research in World Economy, 7(1), 110.

101. Hayek, F. (1943). The Road to Serfdom, Chicago: University of Chicago Press.

102. Heckelman, J. C. (2000). Economic freedom and economic growth: A short-run causal investigation. Journal of Applied Economics, 3(1), 71-91.

103. Heckelman, J. C., \& Stroup, M. D. (2000). Whcich Economic Freedoms Contribute to Growth?. Kyklos, 53(4), 527-544.

104. Ho, C. S. (2020). Economic freedom, macroeconomic fundamentals and foreign direct investment in fast emerging BRICS and Malaysia. International Journal of Banking and Finance, 10(1), 57-73.

105. Hoechle, D. (2007). Robust standard errors for panel regressions with cross-sectional dependence. The stata journal, 7(3), 281-312.

106. Honaker, J., King, G., \& Blackwell, M. (2011). Amelia II: A program for missing data. Journal of statistical software, 45(7), 1-47.

107. Hristova, K. D. (2012). Does economic freedom determine economic growth? A discussion of the Heritage Foundation's Index of Economic Freedom. Doctoral dissertation, Mount Holyoke College.

108. Islam, S. \& Salimullah, A. (2006). Effects of Private Investment, Economic Freedom and Openness on Economic Growth: LDC Experience. Asian Affairs, 28(1), 46-68. 
Ivana Brkić

109. Islam, S. (1996). Economic freedom, per capita income and economic growth. Applied Economics Letters, 3(9), 595-597.

110. Johansen, S. (1988). Statistical analysis of cointegration vectors. Journal of economic dynamics and control, 12(2), 231-254.

111. Jossa, B. (1996). Is European Monetary Union Impossible?. Review of Economic Conditions in Italy, 7(1), 251-265.

112. Justesen, M. K. (2008). The effect of economic freedom on growth revisited: New evidence on causality from a panel of countries 1970-1999. European Journal of Political Economy, 24(3), 642-660.

113. Kapás, J., \& Czeglédi, P. (2007). Economic freedom: theory first, empiricism after. International Centre for Economic Research, 1-26.

114. Karabegović, A., \& McMahon, F. (2005). Economic Freedom of North America. 2005 Annual Report, The Frasier Institute, Vancouver.

115. Karabegovic, A., Samida, D., Schlegel, C. M., \& McMahon, F. (2003). North American economic freedom: an index of 10 Canadian provinces and 50 US states. European Journal of Political Economy, 19(3), 431-452.

116. Keefer, P., \& Knack, S. (1997). Why don't poor countries catch up? A cross-national test of an institutional explanation. Economic inquiry, 35(3), 590-602.

117. Kešeljević, A. (2007). Indexes of economic freedom-An outline and open issues. Proceedings of Rijeka Faculty of Economics: Journal of Economics and Business, 25(2), 223-243.

118. Kešeljević, A. (2013). Global distribution and dynamics of economic freedom: Nonparametric approach. Economic Modelling, 100 (33), 560-571.

119. Khan, M. Z. S. (2012). Examining Friedman hypothesis on political, civil and economic freedom for SAARC countries: a dynamic panel data analysis. Journal of Economic Development, 37(3), 107-127.

120. Kim, D. H., Lin, S. C., \& Suen, Y. B. (2011). Nonlinearity between trade openness and economic development. Review of Development Economics, 15(2), 279-292.

121. Knack, S. (1996). Institutions and the convergence hypothesis: The cross-national evidence. Public Choice, 87(3-4), 207-228.

122. Knack, S. F. (2003). Democracy, governance, and growth. University of Michigan Press. 
Ivana Brkić

123. Knack, S., \& Keefer, P. (1995). Institutions and economic performance: cross-country tests using alternative institutional measures. Economics \& Politics, 7(3), 207-227.

124. Knight, M., Loayza, N., \& Villanueva, D. (1993). Testing the neoclassical theory of economic growth: a panel data approach. Staff papers, 40(3), 512-541.

125. Koopmans, T. (1965). On the concept of optimal growth, The Econometric Approach to Development Planning. Econometric approach to development planning, 1st edn. North Holland, Amsterdam, 225-287.

126. Kormendi, R.C. \& Meguire, P.G. (1985). Macroeconomic determinants of growth: crosscountry evidence. Journal of Monetary Economics, 16(2), 141-163.

127. Kovačević, S., \& Borović, Z. (2014). Economic freedom and economic performance in former socialist countries-panel approach. Proceedings of the Faculty of Economics in East Sarajevo, 1(9), 19-26.

128. Landes, D. S. (1998). The Wealth and Poverty of Nations: Why Some Are So Rich, and Some So Poor. New York: W.W. Norton.

129. Lawson, R. A. (2006). On testing the connection between economic freedom and growth. Econ Journal Watch, 3(3), 398-406.

130. Levente, N. (2015). How Does Economic Freedom Influence The Relationship Between Government Size And Convergence?. Annals of Faculty of Economics, 1(1), 623-630.

131. Levine, R., \& Renelt, D. (1992). A sensitivity analysis of cross-country growth regressions. The American economic review, 82(4), 942-963.

132. Lewis, W. A. (1955). Theory of economic growth. NY: Routledge, (2013).

133. Locke, J. (1690). Of Civil Government. NY: E. P. Dutton, (1942).

134. Lucas, R. E. (1988). On the mechanics of economic development. Journal of monetary economics, 22(1), 3-42.

135. Maassen, G. H., \& Bakker, A. B. (2001). Suppressor variables in path models: Definitions and interpretations. Sociological Methods \& Research, 30(2), 241-270.

136. Madan, A. (2002). The Relationship between Economic Freedom and Socio-Economic Development. University Avenue Undergraduate Journal of Economics, 7(1), 1-59.

137. Mahmood, K., Azid, T., Chaudhry, I. S., \& Faridi, M. Z. (2010). Impact of economic freedom on economic growth: the case of some selected SAARC member countries. International Research Journal of Finance and Economics, 52(1), 7-16. 
Ivana Brkić

138. Malthus, T. R. (1820). Principles of Political and the political processes accountable for their Economy, New York: W. Pickering, (1986).

139. Mankiw, N. G., Romer, D., \& Weil, D. N. (1992). A contribution to the empirics of economic growth. The quarterly journal of economics, 107(2), 407-437.

140. Marjanović, G. (2010). Uticaj ekonomske krize na glavni tok ekonomske misli. Ekonomski horizonti, 12(2), 5-20.

141. Mauro, P. (1995). Corruption and growth. The quarterly journal of economics, 110 (3), $681-712$.

142. Medović, V. (2018). Pojmovnik EU. Beograd: Delegacija Evropske unije u Republici Srbiji.

143. Messick, R.E., ed. (1996). World Survey of Economic Freedom, 1995-1996. New Brunswick: Freedom House and Transaction Publishers.

144. Mill, J.C. (1956). On liberty. NY: Macmillan Publishing Company.

145. Miller, T. \& Kim, B. A. (2016). 2016 Index of Economic Freedom. Washington: The Heritage Foundation and Dow Jones \& Company, Inc.

146. Miller, T., \& Kim, A. B. (2013). Defining economic freedom. In Miller, T., Holmes, K. R., Feulner, E. J., (eds). 2013 Index of Economic Freedom, 87-94, New York: Heritage Foundation, Washington, DC and Wall Street Journal.

147. Miller, T., \& Kim, A. B. (2017). 2017 Index of Economic Freedom. Washington: The Heritage Foundation.

148. Miller, T., Kim, A. B, \& Holmes, K. (2015). Index of Economic Freedom: Promoting economic opportunity and prosperity. Washington: The Heritage Foundation and Dow Jones \& Company, Inc.

149. Miller, T., Kim, A. B. \& Roberts, J. M. (2019). 2019 Index of Economic Freedom. Washington: The Heritage Foundation.

150. N'Zue, F. F. (2011). Economic freedom and performance in ECOWAS countries: A dynamic panel data approach. Africa Journal of Economic Policy, 18(2), 28-53.

151. Nasir, Z., \& Hassan, A. (2011). Economic Freedom, Exchange Rates Stability and FDI in South Asia. The Pakistan Development Review, 50(4), 423-433.

152. North D.C. (1988). Institution, Economic Growth and Freedom: An Historical Introduction, Freedom, Democracy and Economic Welfare, Vancouver: Fraser Institute. 
Ivana Brkić

153. North, D. C. \& Thomas, R. P. (1973). The rise of the western world: A new economic history. Cambridge University Press.

154. North, D.C. (1990) Institutions, Institutional Change, and Economic Performance. Cambridge, U.K.: Cambridge University Press.

155. Norton, S. W. (2003). Economic institutions and human well-being: a cross-national analysis. Eastern Economic Journal, 29(1), 23-40.

156. O’Driscoll, G.P. Jr, Feulner, E.J. \& O’Grady M.A. (2003). 2003 Index of Economic Freedom. Washington, DC: Heritage Foundation and Dow Jones and Company.

157. Ossono, E. (2012). Impact of economic freedom on CEMAC countries, Magister dissertation Sciences of the Nelson Mandela Metropolitan University.

158. Osterfeld, D. (1992). Prosperity versus Planning: How Government Stifles Economic Growth. New York: Oxford University Press.

159. Pääkkönen, J. (2009). Economic freedom as driver of growth in transition. Economic Systems, 34(4), 469-479.

160. Paldam, M. (2003). Economic freedom and the success of the Asian tigers: an essay on controversy. European Journal of Political Economy, 19(3), 453-477.

161. Panahi, H., Assadzadeh, A., \& Refaei, R. (2014). Economic Freedom and Economic Growth in Mena Countries. Asian Economic and Financial Review, 4(1), 105-116.

162. Peev, E., \& Mueller, D. C. (2012). Democracy, economic freedom and growth in transition economies. Kyklos, 65(3), 371-407.

163. Peláez, R. F. (2009). Economic freedom: a comparative study. Journal of Economics and Finance, 33(3), 246-258.

164. Pérez-Moreno, S., \& Angulo-Guerrero, M. J. (2016). Does economic freedom increase income inequality? Evidence from the EU countries. Journal of Economic Policy Reform, 19(4), 327-347.

165. Piątek, D., Szarzec, K., \& Pilc, M. (2013). Economic freedom, democracy and economic growth: a causal investigation in transition countries. Post-Communist Economies, 25(3), 267-288.

166. Pitlik, H. (2002). The path of liberalization and economic growth. Kyklos, 55(1), 57-80.

167. Powell, B. (2003). Economic freedom and growth: the case of the Celtic tiger. The Cato Journal, 22(3), 431-449. 
Ivana Brkić

168. Próchniak, M. (2011). Determinants of economic growth in Central and Eastern Europe: the global crisis perspective. Post-communist economies, 23(4), 449-468.

169. Rajasalu, T. (2003). Indicators of economic freedom and economic structure as determinants of growth and convergence in enlarging EU and priorities for Estonia. Essays in Estonian Transformation Economics. Edited by Ü. Ennuste and L. Wilder, Tallinn, 7-32.

170. Ram, R. (2014). Measuring economic freedom: a comparison of two major sources. Applied Economics Letters, 21(12), 852-856.

171. Romer, P. M. (1986). Increasing returns and long-run growth. Journal of political economy, 94(5), 1002-1037.

172. Romer, P. M. (1990). Endogenous Technological Change, Journal of Political Economy. 98(5): S71-S102.

173. Sachs, J. \& Warner, A. (1997). Fundamental sources of long-run growth. Recent Empirical Growth Research, Area Papers and Proceedings, 87 (2), 184-88.

174. Sachs, J. D. (2001). Tropical Underdevelopment. NBER Working Paper No. W8119 (February). New York: National Bureau of Economic Research.

SAD: Sage publications.

175. Samuelson, P. A., \& Nordhaus, W. D. (2009). Economics. Economics (19 ${ }^{\text {th }}$ Edition). New York. McGraw-Hill/Irwin.

176. Sarvananthan, M. (2004). Economic freedom in South Asia with special reference to Sri Lanka: Research Note. Contemporary South Asia, 13(1), 71-77.

177. Scully, G. W. (1988). The institutional framework and economic development. Journal of Political Economy, 96(3), 652-662.

178. Scully, G. W. (2002). Economic freedom, government policy and the trade-off between equity and economic growth. Public choice, 113(1-2), 77-96.

179. Scully, G. W. (2014). Constitutional environments and economic growth. Princeton University Press.

180. Scully, G. W., \& Slottje, D. J. (1991). Ranking economic liberty across countries. Public Choice, 69(2), 121-152.

181. Sen, A. (1999). Development as Freedom. New York: Alfred A.

182. Smith, A. (2010). The Wealth of Nations: An inquiry into the nature and causes of the Wealth of Nations. Harriman House Limited. 
Ivana Brkić

183. Solow, R. M. (1956). A contribution to the theory of economic growth. The quarterly journal of economics, 70(1), 65-94.

184. Soros, G. (1996). Can Europe work? A plan to rescue the union. Foreign Affairs, 75(5), $8-14$

185. Stansel, D., \& McMahon, F. (2013). Economic Freedom of North America 2013 Annual Report. Vancouver: Frasier Institute.

186. Stiglitz, J.E. (2009). Moving beyond market fundamentalism to a more balanced economy. Annals of Public and Cooperative Economics, 80 (3), 345-360.

187. Sturm, J. E., \& De Haan, J. (2001). How robust is the relationship between economic freedom and economic growth?. Applied Economics, 33(7), 839-844.

188. Sturm, J. E., Leertouwer, E., \& Haan, J. D. (2002). Which economic freedoms contribute to growth? A comment. Kyklos, 55(3), 403-416.

189. Tanzi, V. (2005). The Economic Role of the State in the 21st Century, Cato Journal, 25(3), 617-638.

190. Tiwari, A. (2011). Foreign Aid, FDI, Economic Freedom and Economic Growth in Asian Countries. Global Economy Journal, 11(3), 1-28.

191. Türedi, S. (2013). The effect of economic freedom on economic growth: A panel data analysis for 12 Islamic countries. International Research Journal of Finance and Economics, 107(2), 154-162.

192. us Swaleheen, M., \& Stansel, D. (2007). Economic freedom, corruption, and growth. Cato Journal, 27(3), 18-25.

193. Vedder, R. K., \& Gallaway, L. E. (1998). Government size and economic growth. Washington: Joint Economic Committee.

194. Vega, G.M. \& L. Alvarez (2003). Economic growth and freedom: A causality study. Cato Journal, 23(2), 199-215.

195. Vukotić, V. \& Baćović, M. (2006). Economic freedom and economic growth in South East Europe. Transition Studies Review, 13(1), 81-91.

196. Wu, C. (2011). Economic freedom, economic growth, and China. Chinese economy, 44(5), 104-119. 
Ivana Brkić

197. Zghidi, N., Mohamed Sghaier, I., \& Abida, Z. (2016). Does economic freedom enhance the impact of foreign direct investment on economic growth in North African countries? A panel data analysis. African Development Review, 28(1), 64-74. 